
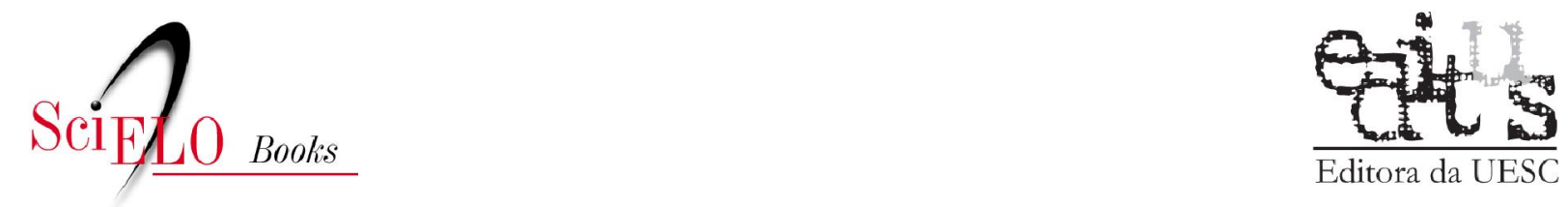

Editora da UESC

\title{
Questões teóricas e formação profissional em comunicação e educação
}

\author{
Eliana Nagamini (org.)
}

SciELO Books / SciELO Livros / SciELO Libros

NAGAMINI, E., org. Questões teóricas e formação profissional em comunicação e educação [online]. Ilhéus, BA: Editus, 2015, 287 p. Comunicação e educação series, vol. 1. ISBN 978-85-7455439-6. Available from SciELO Books $<\underline{\text { http://books.scielo.org }>\text {. }}$

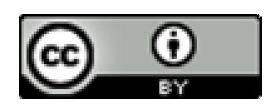

All the contents of this work, except where otherwise noted, is licensed under a Creative Commons Attribution $\underline{4.0 \text { International license. }}$

Todo o conteúdo deste trabalho, exceto quando houver ressalva, é publicado sob a licença Creative Commons Atribição 4.0.

Todo el contenido de esta obra, excepto donde se indique lo contrario, está bajo licencia de la licencia Creative Commons Reconocimento 4.0. 


\section{Cómunicação \\ e Educação}

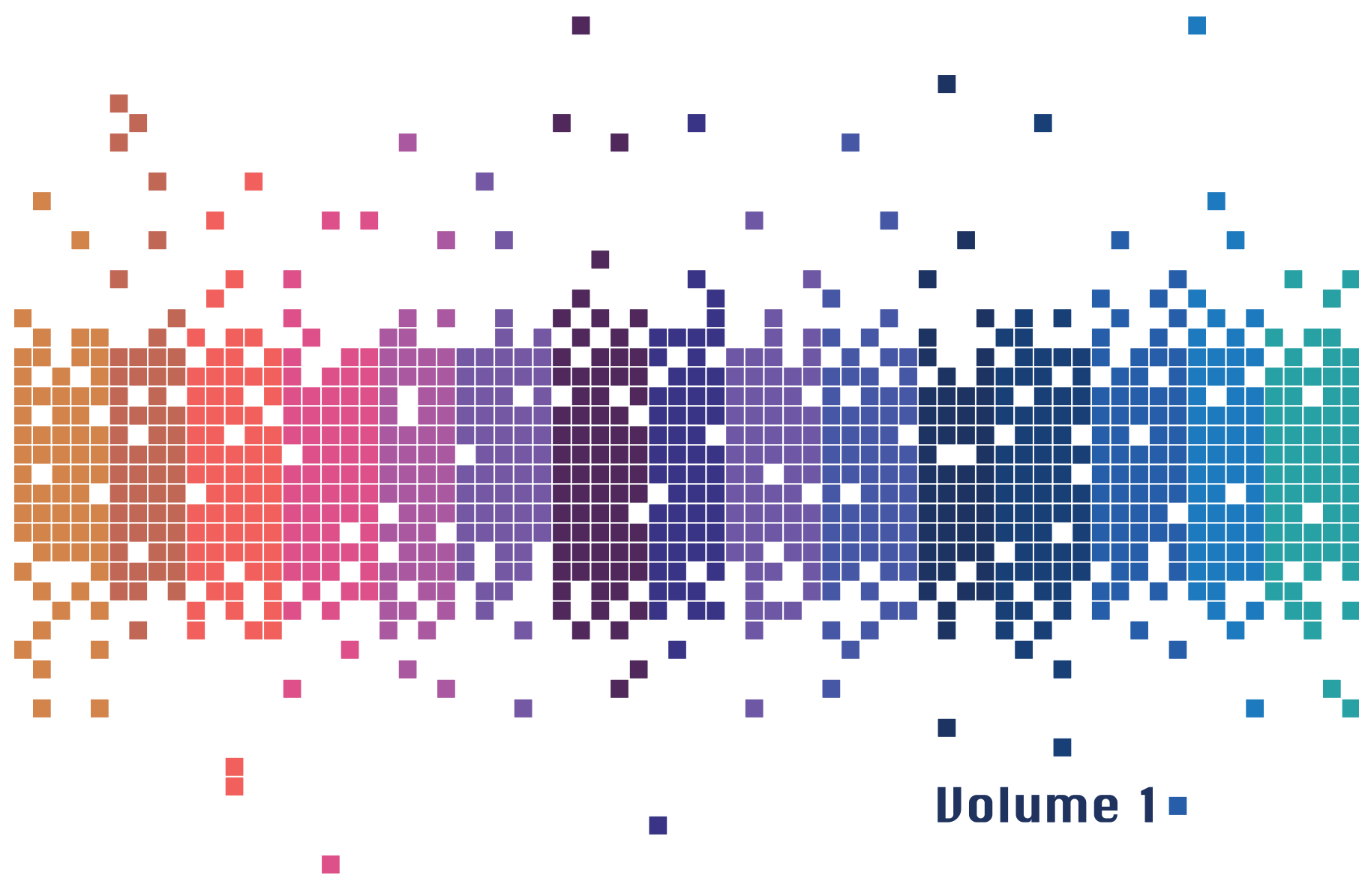




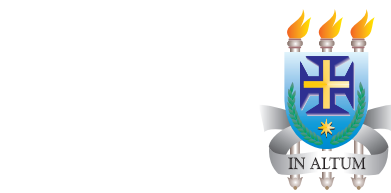

\section{Universidade Estadual de Santa Cruz}

\section{GOVERNO DO ESTADO DA BAHIA}

Rui Costa - Governador

\section{SECRETARIA DE EDUCAÇÃO}

Walter Pinheiro - Secretário

\section{UNIVERSIDADE ESTADUAL DE SANTA CRUZ}

Adélia Maria Carvalho de Melo Pinheiro - Reitora

Evandro Sena Freire - Vice-Reitor

\section{DIRETORA DA EDITUS}

Rita Virginia Alves Santos Argollo

\section{Conselho Editorial:}

Rita Virginia Alves Santos Argollo - Presidente

André Luiz Rosa Ribeiro

Andrea de Azevedo Morégula

Adriana dos Santos Reis Lemos

Evandro Sena Freire

Francisco Mendes Costa

Guilhardes de Jesus Júnior

José Montival de Alencar Júnior

Lúcia Fernanda Pinheiro Barros

Lurdes Bertol Rocha

Ricardo Matos Santana

Rita Jaqueline Nogueira Chiapetti

Samuel Leandro Oliveira de Mattos Sílvia Maria Santos Carvalho 
Direitos desta edição reservados à

EDITUS - EDITORA DA UESC

A reproduçáo náo autorizada desta publicaçáo, por qualquer meio, seja total ou parcial, constitui violação da Lei no 9.610/98.

Depósito legal na Biblioteca Nacional, conforme Lei no 10.994 , de 14 de dezembro de 2004.

\section{PROJETO GRÁFICO E CAPA}

Alencar Júnior

\section{DIAGRAMAÇÁO}

Álvaro Coelho

\section{REVISÃO}

Gabriela Amorim de Santana

Dados Internacionais de Catalogação na Publicação (CIP)

Q5 Questões teóricas e formação profissional em comunicação e educação / Eliana Nagamini, organizadora. - Ilhéus, BA: Editus, 2016.

287 p. - (Série Comunicação e Educação; v. 1).

Inclui referências.

ISBN: 978-85-7455-411-2

1. Comunicação. 2. Comunicação e educação. 3. Comunicação - Estudo e ensino. 4. Comunicacação - Pesquisa. I. Nagamini, Eliana. II. Série.

CDD 302.2

\section{EDITUS - EDITORA DA UESC}

Universidade Estadual de Santa Cruz

Rodovia Jorge Amado, km 16 - 45662-90o - Ilhéus, Bahia, Brasil

$$
\begin{gathered}
\text { Tel.: (73) 3680-5028 } \\
\text { www.uesc.br/editora } \\
\text { editus@uesc.br }
\end{gathered}
$$

\section{EDITORA FILIADA À}

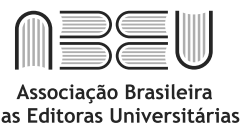


SUMÁRIO

Apresentação $\mid 7$

PARTE 1

CONSTRUÇÃO EPISTEMOLÓGICA NA INTERFACE COMUNICAÇÃO E EDUCAÇÃO

Comunicação e Educação: o problema da aceleração temporal Adilson Citelli

Comunicação e Educação: as distintas trajetórias no espaço ibero-americano

Richard Romancini

Comunicação e Educação: convergência e imagens como meios de campo Ana Cristina Teodoro da Silva

Comunicação, Educação e Cultura: possíveis inter-relações no contexto da sociedade midiatizada Camila de Alvarenga Assis e Silva

A mediação educomunicativa e o princípio da indissociabilidade entre ensino-pesquisa-extensão: da monocultura universitária à cultura plural Rosane Rosa

Educomunicação e Midiaeducação: um estudo comparativo entre as cidades de São Paulo e Rio de Janeiro Elisangela Rodrigues da Costa

Educomunicação e transmidiação: considerações sobre audiência, protagonismo e ressignificações Cláudio Messias

Linguagens nos modos de narrar: possibilidades e desafios para a Educomunicação 
PARTE 2

PROCESSOS EDUCACIONAIS E COMUNICACIONAIS PARA FORMAÇÃO DO PROFISSIONAL DE COMUNICAÇÃO

Desenvolvimento de capital cultural digital e prossumidores: perspectivas de atuação em rede para os formandos em jornalismo Cláudia Maria Moraes Bredarioli

O diálogo da extensão e da pesquisa: algumas possibilidades para pensar a educação na cultura da mídia Saraí Schmidt Alisson Brum

A Contribuição da Educomunicação para o ensino superior Rose Mara Pinheiro

A aprendizagem baseada em problemas no ensino de jornalismo Ângela Ravazzolo Janine Marques Passini Lucht

Texto, cena e a formação pela experiência Mei Hua Soares

Práticas pedagógicas no ensino de assessoria de comunicação em universidades públicas: UFPel e Unipampa Elisa Lübeck Terra

Carmen Abreu Marislei Ribeiro

Educomunicação e a interface com o ensino na graduação Diva Souza Silva Christiane Pitanga Serafim da Silva

Representação da literatura brasileira no jornalismo em língua alemã Sonia Breitenwieser Alves dos Santos Castino

Experiência de um laboratório de aprendizagem intercursos de PP e RP Alessandra Ferreira

A formação ética dos jornalistas: relato de experiência docente Sérgio Rodrigo da Silva Ferreira 


\section{Apresentação}

\section{Série Comunicação e Educação}

Os artigos publicados nesta coletânea foram apresentados no GP Comunicação e Educação do XXXVIII Congresso Brasileiro de Ciências da Comunicação/Intercom, promovido pela Sociedade Brasileira de Estudos Interdisciplinares da Comunicação, realizado no Rio de Janeiro, em 2015.

O Grupo de Pesquisa Comunicação e Educação integra a Divisão Temática Interfaces Comunicacionais, da Intercom. Os estudos apontam referenciais teóricos e metodológicos que permitem compreender as interferências dos processos comunicacionais nos modos de aprender e ensinar, em espaços educativos formais, informais e não formais.

Para esta publicação, os artigos sofreram pequenas modificações, atualizando dados ou acrescentando informações e reflexões decorrentes das contribuições teóricas e metodológicas dos pesquisadores.

O volume 1 - Questões teóricas e formação profissional em Comunicação e Educação - inicia com estudos sobre a "Construção epistemológica na interface Comunicação e Educação", em que são operados termos como Educomunicação, Mídiaeducação, Transmidiação ou Comunicação/ Educação. Trazem contribuições teóricas que, para além dos conceitos utilizados, procuram refletir acerca das interfaces envolvidas nos vínculos da Comunicação com a Educação. Já os "Processos educacionais e comunicacionais para formação do profissional de Comunicação" discutem metodologias afeitas ao aprender e ensinar na graduação e cursos de extensão.

O volume 2 - Processos educativos na interface Comunicação e Educação - apresenta artigos com enfoque nos "Processos educativos e os meios de comunicação" voltados a verificar quais são as interferências dos meios de comunicação no contexto educativo. Em "Narrativas em linguagem visual/audiovisual: reflexões sobre práticas educativas" destacam-se estudos 
sobre a presença de discursividades produzidas pelos meios de comunicação em que se operam linguagens verbais e não verbais e podem compor atividades didático-pedagógicas.

No volume 3 - Práticas educativas e interatividade em Comunicação e Educação - em "Projetos e práticas comunicacionais em espaços educativos", os artigos mostram a presença da Comunicação como possibilidade de ampliação da participação cidadã e de preservação dos Direitos Humanos, desde que implicada com perspectiva educativa emancipadora. Em "Interatividade, tecnologia e ensino", os espaços virtuais são tratados como lugares dos novos modos de aprender e ensinar que exigem outro olhar para a importância do letramento digital.

O desafio para reunir diferentes pesquisadores, marcados por diferentes experiências e perspectivas, tornou-se profícuo por fornecer aos estudiosos da interface Comunicação e Educação um conjunto relevante de textos, que certamente contribuirão para o avanço em nossa área de pesquisa.

Nesta empreitada, vale destacar agradecimentos especiais ao Prof. Dr. Adilson Odair Citelli pela presença constante nos Congressos e o incentivo às novas publicações decorrentes desses debates; à Rita Virginia Argollo, Diretora da Editus (UESC), pelo acompanhamento e publicação dos artigos, abrindo a série Comunicação e Educação.Também para Ana Luisa Zaniboni Gomes e Cláudia Maria Moraes Bredarioli pela leitura crítica dos artigos que foram apresentados no ano de 2015 .

Eliana Nagamini

Coordenadora do GP Comunicação e Educação

Intercom (2014-2015) 


\section{PARTE 1}

Construção epistemológica na interface Comunicação e Educação 


\section{Comunicação e Educação: o problema da aceleração temporal ${ }^{1}$}

Adilson Citelli ${ }^{2}$
Universidade de São Paulo, São Paulo, SP

O conjunto de indagações que circundam os estudos postos na interface comunicação/educação - educomunicação - apresentam desafios de várias naturezas cujos alcances requisitam da parte dos interessados dupla inflexão, seja para qualificar os mecanismos de pesquisa seja para identificar tendências e desdobramentos colocados pela própria dinâmica técnica e tecnológica que envolve os mundos da escola e dos dispositivos comunicacionais. Vale dizer, tratamos de tema que possui, ao mesmo passo e em estreito vínculo, decisivo enraizamento institucional - no caso evidenciado neste artigo, a educação formal -, e modulações tecnoculturais ou tecnossociais que elegeram a instabilidade e o dinamismo interno como marcas singulares.

A metáfora de Marx segundo a qual tudo o que é sólido se desmancha no ar funciona para referenciar as contínuas mudanças dos aparatos produtivos, mas que ganharam, contemporaneamente, impressionante

1 Trabalho originalmente apresentado no GP Comunicação e Educação, Congresso INTERCOM, Rio de Janeiro, 2015. Aqui foram procedidos ajustes para a forma de artigo.

2 Prof. Titular junto ao Departamento de Comunicações e Artes. Escola de Comunicações e Artes da Universidade de São Paulo (ECA/USP). Pesquisador 1 C do CNPq. Coeditor da revista Comunicação \& Educação. Autor, entre outros livros e artigos, de: Imagens do professor na mídia (Org.). São Paulo, Paulinas, 2012; Educomunicação. Construindo uma nova área do conhecimento. São Paulo, Paulinas, 2011. Volume organizado com Cristina Costa; Palavras, meios de comunicação e educação. São Paulo, Cortez, 2006; Comunicação e educação. A linguagem em movimento. São Paulo, SENAC, 2000; Linguagem e persuasão. São Paulo, Ática, 2000. 
profundidade e celeridade. A dialética entre construção, transformação e destruição esclareceu-se como inequívoca evidência, sobretudo, no que vem sendo chamado de mundo pós-industrial, tanto na profusa e transitória oferta de mercadorias que recheiam gôndolas de supermercados e vitrines de shopping centers quanto no próprio setor financeiro, com a sua peculiar oferta dos chamados produtos/serviços bancários, um leque de papéis, títulos e operações sobre indexadores que alcançam do segmento acionário ao de câmbio, basicamente marcados pela imaterialidade, mas com força suficiente para repercutir com enorme rapidez nos mercados mundiais.

Sem o desejo redutor de criar sobredeterminações mecânicas, é imperioso reconhecer que as estratégias de organizar os andamentos do capital, as constantes mutações dos instrumentos de produção, em especial quando se observam as inovações trazidas pela ampla digitalização dos sistemas, os novos modos de constituição das sociabilidades, em forte nexo com os dispositivos da comunicação substanciados em telas pequenas e nas tecnologias locativas, têm repercutido diretamente na maneira de organizar as relações de tempo e espaço.

Há uma série de autores dedicados a pensar essa dimensão cronotópica do sujeito contemporâneo insistindo na perspectiva de que os ritmos do tempo social ganharam não apenas ângulo especioso, mas passaram, também, a expressar contradições com o tempo das instituições. De um lado, o compasso é o da aceleração e, do outro, da dilação. É o que pensam, em registros e explorando vertentes um pouco distintas do mesmo problema, nomes como os do sociólogo alemão Hartmut Rosa (2013) ou do norte-americano Jonathan Crary (2014), ao tratarem dos novos cenários abertos pela aceleração social. Em torno desta variável teórica, vemos irromper uma série de subtemas que incluem desde a fragilização das instituições tradicionais até o controle do sono, graças a uma estratégia do capitalismo tardio para, se possível, fazer desaparecer a lua, entronizando o sol como o senhor da luz permanente que sinalizaria estarem as vinte e quatro horas à disposição dos negócios e dos fluxos da produção e do consumo.

O desajuste posto no coração da alta modernidade entre a rapidez do tempo social, ritmado pelas revoluções técnicas, pelas mudanças nos percursos da vida, e a morosidade das instituições, incluindo os mecanismos de governança, a estrutura da família ou do judiciário, traz consigo uma série de resultantes que tanto dizem respeito às maneiras de promover a circulação do conhecimento e da informação quanto à afirmação do consumismo, do individualismo, da experiência radicalizada daquilo que David Riesman 
(1995), com enorme acuidade, ainda nos anos 1950, caracterizou como sendo a marca da nova classe média norte-americana, constituída por um ajuntamento de insulados, a caminhar rumo à introdireção e a alterdireção³.

Nesta linha, Hartmurt Rosa pensa as mudanças que marcam os compassos do mundo contemporâneo, a partir de três indicadores centrais: a rapidez dos sistemas e processos tecnológicos, manifestados em áreas de transporte, comunicação e produção - é possível eleger, aqui, o efêmero como traço constitutivo de variados tipos de mercadorias; a aceleração das mudanças sociais, identificáveis nos âmbitos da cultura, das instituições e das relações pessoais; a dinamização nos ritmos de vida, expressão de certo paradoxo, pois seria esperado que as facilidades carreadas pelas tecnologias trouxessem consigo um aumento do tempo livre das pessoas, ampliando o lazer e permitindo o chamado ócio criativo ${ }^{4}$. Para o sociólogo alemão, as marcas estruturais e culturais das instituições estariam em choque com o shrinking of the present ${ }^{5}$, aquele fragmento temporal em que se diminuem as marcas do passado e se ampliam as expectativas do futuro, imprimindo no hic et nunc a estranha sensação de existir apenas um cenário de "passagem", da fugacidade caracterizada por um instante de perigo ${ }^{6}$.

3 A evidência acerca do aumento espantoso no número de pessoas que estão vivendo sozinhas tem trazido à luz trabalhos como os de Eric Klinenberg (2012), que mostram a extensão do assunto. Se na época em que Riesman publicou o seu conhecido livro, à altura dos anos 1950, havia 4 milhões de americanos vivendo sós, em seu trabalho, Klinenberg indica o número atual de 30 milhões, sendo que na zona de Manhattan, em Nova Iorque, a metade dos moradores ocupa habitações individuais. E prossegue apontando que entre as causas deste fenômeno estão: as transformações na comunicação, a revolução urbana, o aumento da longevidade, a redefinição do papel social da mulher. Claro está que parece insuficiente imaginarmos que a multidão deixou de ser "solitária" apenas porque se encontra conectada compartilhando as mesmas redes sociais, os mesmos blogs. A complexidade ontológica do problema merece inflexão mais detida em espaço próprio.

4 Friedrich Nietzche falando sobre a pressa que marcava a vida nos Estados Unidos, motivo pelo qual as pessoas se envergonhavam do descanso, sendo asfixiadas pela ideia de que era melhor fazer qualquer coisa do que nada, termina na amarga constatação segundo a qual a civilização ganhou ares de barbárie por haver perdido a capacidade de se tranquilizar. Isto é, de aceitar o movimento lento da reflexão, dos achados no campo da arte e da cultura. Acerca deste ponto, ler: Giacoia Júnior, Oswaldo. Ansiedade sem aplicativo. In: O Estado de São Paulo. 28/06/2015.

5 A afirmativa de que existe um "encolhimento do presente" aparece em várias passagens do livro de Rosa, Social acceleration. A new theory of modernity (2013).

6 Para retomar a conhecida afirmativa de Walter Benjamin (1985). 
O encolhimento do presente, ou ao menos a sensação de que ele ficou demais estreito, em certa medida resultante da aceleração tecnológica e da própria vida cotidiana, sugere que à fluidez do tempo corresponderia o enfraquecimento dos laços sociais e das relações interpessoais. Daí, para retomar o pensamento de Riesman, ser possível falar em introdireção e alterdireção, instâncias convergentes e marcadas por uma perspectiva de fechamento e isolamento dos indivíduos, o que não deixa de carregar curiosa ironia e preocupante paradoxo, pois, ao menos segundo a retórica do nosso tempo, viveríamos sob a larga abrangência da globalização integradora, plugados em redes interconectas on line, portanto longe de compor a multidão de solitários. Considerado por este viés, no qual as manobras da linguagem e as dinâmicas societárias fingem acertar o passo, o problema da aceleração social pode ser pensado como uma orquestra que traz dentro de si elementos disfuncionais, resultando em desencontros entre o piano e o violino, e afetando a performance final do concerto.

A mesma perspectiva do "revolucionar permanente", destacada por Marx em seu manifesto, e que afirmaria a transitoriedade como determinativo do modo de produção capitalista e da burguesia em busca constante de inovação e racionalização do trabalho é reposta por Jonathan Crary, no seu já citado ensaio acerca da afronta que o ato de dormir parece provocar no capital. O estado de plena felicidade - para quem domina os meios de produção, o comércio, a circulação do dinheiro - seria aquele no qual fosse possível manter os ritmos laborais em funcionamento nas vinte e quatro horas e nos sete dias da semana, prática, ademais, a plena carga em grandes cidades do mundo. Aqui, é útil relembrar, a contrapelo, a observação de Nietzche, para quem, a tranquilidade, o sossego e o ócio estariam associados semanticamente ao tempo de larga duração, requisito último para se exercitar a capacidade de pensar, fruir a arte, perseguir a liberdade do espírito, enfim, um direito de viver sem os atropelos do shrinking of the present, ou, se quisermos atualizar e particularizar o reclamo: afastando a tentação do Facebook, do WhatsApp, do e-mail, e quejandos.

O problema, segundo formulado por Jonathan Crary, é que a transitoriedade ancora-se -, não de hoje, mas agora como vetor decisivo, em uma situação de permanência, motivo pelo qual o conceito, por exemplo, de "era digital" resulta, ele mesmo, em tipo singular de boutade, visto cristalizar uma fração temporal que consigna autonomia, independência histórica, fingindo estabilidade onde habita instabilidade:

No entanto, a realidade bastante diversa de nosso tempo se caracteriza como manutenção calculada de um estado de transição contínuo. Diante de exigências tecnológicas em transformação constante, jamais 
haverá um momento em que finalmente as alcançaremos, seja enquanto sociedade seja enquanto indivíduo (CRARY, 2014, p. 46).

E prossegue lembrando que não estamos diante de algo novo acrescentamos nós, mas apresentando, agora, ritmos, alcances e profundidades irrecorríveis - haja vista existir:

incompatibilidade intrínseca do capitalismo com formações sociais estáveis ou duradouras, e a história dos últimos 150 anos é inseparável da "revolução contínua" das formas de produção, circulação, comunicação e construção de imagens (CRARY, 2014, p.47).

Em síntese, Hartmurt Rosa e Jonathan Crary convergem no atinente ao ponto que estamos destacando como uma das marcas caracterizadoras da alta modernidade: a pressa, a velocidade, o açodamento, tudo seguido da superoferta de mercadorias, o que combina, em procedimentos de retroalimentação, com o consumismo e a alterdireção. Ou, nos termos de Crary (2014, p. 52):

Esse fenômeno contemporâneo da aceleração não é simplesmente uma sucessão linear de inovações, na qual cada item obsoleto é substituído por um novo. Cada substituição é sempre acompanhada por um aumento exponencial do número de escolhas e opções disponíveis. É um processo contínuo de distensão e expansão, que ocorre simultaneamente em diferentes níveis e em diferentes lugares, um processo no qual há uma multiplicação das áreas de tempo e experiência que são anexadas a novas tarefas e demandas envolvendo máquinas. A lógica do deslocamento (ou obsolescência) é conjugada a uma ampliação e diversificação dos processos e fluxos aos quais o indivíduo se vincula efetivamente.

Posto de outra maneira, os mecanismos da aceleração e da diversificação tecnológica criam os ambientes ou os fluxos no interior dos quais os indivíduos - respeitando-se particularidades culturais, de classes, econômicas, etc. - definem interesses, conformam valores, entram no debate público, assumem formações discursivas, ativam processos comunicacionais, enfim, singularizam mecanismos de integração na dinâmica social e de construção das sociabilidades. Diante deste quadro, fica no ar a pergunta acerca de como as instituições tradicionais, aquelas responsáveis, em tese, pela formação educativa, religiosa, política, ética, moral, à maneira das escolas, igrejas, partidos, famílias, etc., localizam-se frente aos mecanismos de aceleração social, da decisiva dominância dos mediadores tecnocomunicativos, do aparente desconforto resultante do shrinking of the present. 
Ao seguirmos as reflexões acima, impõe-se abrir duas vertentes quando a matéria de referência é o universo da educação formal. De um lado, o encolhimento do presente, com a sua marca transitiva em ritmo acelerado, no qual os mediadores técnicos da comunicação jogam papel importante. Tais mediadores, eles próprios cifrados pela curta duração, pela "obsolescência constitutiva”, a ser acompanhada in praesentia nas vitrines das lojas, nas ofertas que inundam as páginas da internet, a exemplo dos celulares, e a sua sequência quase fetichista de gerações que se sucedem anualmente, num infindável atropelo de Gs: 1, 2, 3, 4, etc.

De outro lado, a escola como unidade marcada por configuradores institucionais desenvolvidos segundo outra lógica temporal, com os seus ritos e a convivência com o tempo lento, necessário aos processos de (in)formação, sistematização, maturidade reflexiva, vínculos com o conhecimento, etc.

$\mathrm{O}$ "revolucionar permanente" possui, aqui, outro sentido, implicado, em particular, com a ordem do saber, do conhecimento, da pesquisa, dos avanços no âmbito das ciências, circunstâncias todas que lançam olhar desconfiado para o sentimento de urgência. A se lembrar o significado do substantivo formação (erfahrung) que diz respeito aos vínculos dos sujeitos com os planos objetivos e subjetivos, ademais, articulados no território da experiência, logo, da vivência/maturidade. E, para tanto, impõem-se, ainda seguindo a já citada metáfora nietzschiana da tranquilidade, certa lentidão incompatível com o estreitamento do tempo presente, aquele no qual a escola precisa realizar a sua operação formativa.

Equivale dizer que a tensão temporal e de imperativos pragmáticos entre as dinâmicas da transitividade marcada pelo sentimento de urgência e o aparato das instituições tradicionais está posta de maneira vigorosa para a educação formal. Nesse descompasso, podem ser localizadas algumas das várias fragilidades que matizam o sistema escolar brasileiro, cuja tradução pública, muitas vezes espetacularizada pela mídia, traduz-se nas críticas ao currículo $^{7}$, à defasagem dos programas de ensino, ao despreparo dos professores, à leniência das autoridades governamentais, ao acesso de milhões de jovens das classes populares ao ensino público, à tibieza nas avaliações, ao

7 Está em fase final de discussão a Base Nacional Comum Curricular, que deverá orientar a construção dos currículos das escolas de ensino básico no país. 
paternalismo, ao abastardamento do que teria possuído nobreza no passado, para ficarmos em itens de uma lista infindável. A contraparte do diagnóstico, isto é, a requalificação da escola, seria possível, por outra série de tópicos formulados, segundo o lugar social, político ou ideológico da enunciação, através do rigor nas aprovações/reprovações dos alunos, do adestramento para operações como a tabuada, a leitura, a escrita, da retomada do enciclopedismo propedêutico, da férula da repressão aos discentes desajustados na sala de aula, da cobrança de resultados por metas impostas aos docentes, da mudança nos padrões de financiamento da educação, na reorganização da escola segundo o modelo dos ciclos únicos ${ }^{8}$, etc.

Independentemente da procedência de algumas das cláusulas salvadoras postas acima, pouco ocorre às críticas sobre a escola atual uma nova visagem acerca dos contornos culturais ou dos desafios apresentados pela questão da temporalidade e da presença das tecnologias da comunicação e da informação nos configuradores institucionais e na sociabilidade dos jovens e adolescentes. Acerca destes últimos reptos, talvez pela complexidade que apresentam e pela própria dificuldade de acompanhar os seus deslocamentos, reina um desconfortável silêncio. Parece persistir uma consciência que pergunta, mas se esquiva de oferecer resposta, preferindo continuar na rota do cronos que rege, tradicionalmente, a instituição escolar, eximindo-se, portanto, de apreender as temporalidades localizadas, também, fora das salas de aula. E nestes outros lugares, igualmente carregados de contradições, habita o amplo território da comunicação, seus mediadores, suas tecnologias, seus apelos de velocidade e aceleração do tempo social, que marcam a fundo os modos de ser, aprender e conviver, dos jovens e cujas convergências encontram, por vias diretas ou indiretas, os espaços da educação formal.

Das questões apontadas nos tópicos acima foi possível, de forma sintética e nos limites dados por este artigo, destacar algumas categorias: "shrinking of the present", processos formativos, aceleração do tempo. E acrescentar que tais linhas de força ganharam evidência graças à pesquisa que realizamos junto à rede pública de ensino. No contato com os professores e alunos identificamos temas e subtemas que, à maneira daquelas categorias, podem contribuir para o avanço nos estudos postos na interface

8 Como decorrência da aplicação de modelos de gestão cujo olho parece sempre voltado para a redução de custos, traduzido no termo reorganização da escola, ocorreram, no final de 2015, os conflitos entre o governo do Estado de São Paulo/Secretaria de Educação, e os estudantes do sistema público paulista. 
comunicação/educação. A seguir detalharemos alguns aspectos da referida investigação.

\section{3}

A pesquisa, em sua angulação maior, realizou-se durante o segundo semestre de 2013 e o primeiro de 2015 , envolvendo 197 docentes e 669 discentes. Aqueles estavam alocados em 32 escolas espalhadas pelas zonas norte, sul e oeste da cidade de São Paulo, afora municípios dispersos em raio próximo dos 200 km da capital, compreendendo Osasco, Barueri, São Roque, Taubaté, Tremembé, São José dos Campos e Avaré.

Os discentes distribuíram-se por 24 escolas, localizadas geograficamente nas regiões e cidades acima mencionadas. A diferença entre o número de unidades educativas associadas aos professores, com relação aos estudantes, decorre do fato de atuarem em mais de uma unidade educativa, às vezes na mesma região, outras até em cidades diversas. A capilaridade da amostra foi possível graças ao trabalho de orientandos e colaboradores ${ }^{9}$ que exercem o magistério ou realizam pesquisas na interface comunicação e educação.

A nossa investigação utilizou dois instrumentos centrais: o contato pessoal com depoentes e um questionário com 45 perguntas fechadas ou abertas dirigidas a docentes; e outro, com as mesmas características, mas contendo 36 questões voltadas aos discentes. O material foi consolidado, em sua maior parte tabulado e traduzido em números e gráficos, analisado e, naquilo que se reconheceu como pertinente para o escopo deste artigo, utilizado para alimentar comentários e análises.

Os dados totais coletados permitiram o acesso a informações e manifestações atinentes a um conjunto amplo de perguntas, segundo orientadas aos professores ou aos estudantes, alimentadoras das dinâmicas escolares, das práticas educativas, dos interesses culturais, dos hábitos midiáticos, das ligações com os ambientes digitais, enfim, dos distintos planos que singularizam os vínculos da comunicação com a educação.

As bases em que se deram alguns encontros com alunos, certas precariedades nas escolas, por vezes desalento entre docentes, tendo por pano

9 Maria do Carmo Souza de Almeida, Elisangela Rodrigues da Costa, Sandra Pereira Falcão e Guilherme Yazaki. 
de fundo as delicadas condições de existência da rede de ensino, sobretudo aquela de natureza pública - que abrangeu a maioria das escolas referidas aos depoentes, em torno de $70 \%$ - permitiram aproximar diversas realidades da educação formal em algumas regiões da cidade e do Estado de São Paulo.

À frente arrolamos alguns dados da pesquisa, seguidos de comentários, a fim de mais bem conectá-los com a síntese conceitual realizada nos tópicos anteriores.

1. Acerca dos equipamentos existentes nas escolas pesquisadas. As respostas permitiam a indicação de mais do que uma alternativa.

\section{Professores}

\begin{tabular}{l|l|l}
\hline Televisão & 189 & $97 \%$ \\
\hline Rádio & 156 & $80 \%$ \\
\hline Gravador de áudio & 66 & $34 \%$ \\
\hline DVD & 178 & $92 \%$ \\
\hline Câmera fotográfica & 139 & $72 \%$ \\
\hline Filmadora & 91 & $47 \%$ \\
\hline Powerpoint (projetor) & 138 & $71 \%$ \\
\hline Outros & 88 & $45 \%$ \\
\hline
\end{tabular}

Alunos

\begin{tabular}{l|l|l}
\hline Televisão & 562 & $81 \%$ \\
\hline Rádio & 472 & $68 \%$ \\
\hline Câmera fotográfica & 309 & $45 \%$ \\
\hline Aparelho de DVD & 522 & $76 \%$ \\
\hline Filmadora & 190 & $28 \%$ \\
\hline Gravador de áudio & 113 & $16 \%$ \\
\hline PowerPoint (projetor) & 463 & $67 \%$ \\
\hline Outros & 129 & $19 \%$ \\
\hline
\end{tabular}

As indicações dos docentes e discentes coincidem no fundamental. Algumas diferenças nos números absolutos derivam de eventuais intercorrências nas respostas dos estudantes movidas, muitas vezes, por desinformação sobre os dispositivos existentes nas unidades educativas pesquisadas, ou são apenas elisões de rubricas que permitem mais de uma resposta. A televisão surge em $1^{\circ}$ lugar, indicada por $97 \%$ dos docentes e por $81 \%$ dos discentes, no mais, a sequência é praticamente a mesma. Vale destacar que equipamentos como câmeras fotográficas, filmadoras ou Power Point são mencionados com 
razoável frequência. No caso dos professores, em 71\%; e na dos estudantes, em 67\%, o PowerPoint é pontuado, revelando que vai se tornando um dos recursos presentes nas salas de aula do ensino básico.

\section{Escolas com computadores.}

\section{Professores}

\begin{tabular}{l|l|l}
\hline Computador sem internet & 61 & $31 \%$ \\
\hline Computador com internet & 163 & $84 \%$ \\
\hline Computador nas salas de aula & 15 & $8 \%$ \\
\hline Computador na sala dos professores & 145 & $74 \%$ \\
\hline Computador na secretaria/diretoria & 184 & $94 \%$ \\
\hline Sala de informática & 170 & $87 \%$ \\
\hline Não possui computadores & 0 & $0 \%$ \\
\hline
\end{tabular}

\section{Alunos}

\begin{tabular}{l|l|l}
\hline Computador sem internet & 135 & $19 \%$ \\
\hline Computador com internet & 586 & $84 \%$ \\
\hline Computador nas salas de aula & 107 & $15 \%$ \\
\hline Sala de informática & 607 & $87 \%$ \\
\hline Não possui computador & 15 & $2 \%$ \\
\hline
\end{tabular}

Também neste caso, há indicadores convergentes entre professores e alunos, sobretudo naquilo que nos interessa diretamente, e que diz respeito seja à existência das salas de informática $(87 \%)$ seja de computador com internet (84\%). Tal realidade quase universalizada, nas escolas que compuseram o nosso corpus, no afeito à existência de computadores com conexão, permite dizer, ao menos neste particular, que as unidades de ensino não se encontram alheias ao movimento geral de digitalização que acompanha os encadeamentos das comunidades educativas com a sociedade inclusiva.

3. Procuramos saber dos alunos se a existência dos recursos tecnológicos poderia contribuir para melhorar a qualidade da aula:

\begin{tabular}{l|l|l}
\hline Depende & 7 & $1,18 \%$ \\
\hline Não & 12 & $2,03 \%$ \\
\hline Sim & 12582 & $98,47 \%$ \\
\hline
\end{tabular}

Vale dizer que as aulas baseadas apenas em recursos expositivos, ou magistrais, podem encontrar barreiras junto aos jovens frequentadores do 
ensino básico. E os números são claros, pois a quase totalidade dos pesquisados $(98,47 \%)$ vinculam a melhoria na qualidade das aulas ao acionamento das possibilidades técnicas hoje à disposição dos docentes, conforme tabelas anteriores. Parece ocioso acentuar que a resposta está em linha com a forma de os chamados nativos digitais se relacionarem com os circuitos da comunicação, dos acessos à informação e mesmo a certas formas de conhecimento.

4. Em seguida, indagamos se os professores, para o andamento das aulas, faziam uso de notícias dos jornais, revistas, propagandas, letras de música, filmes.

Seguiram-se as respostas:

\begin{tabular}{l|l|l}
\hline Sim & 579 & $83 \%$ \\
\hline Não & 111 & $16 \%$ \\
\hline
\end{tabular}

Frente à constatação da crescente utilização de estratégias didáticas para promover as atividades, agregamos outra pergunta aos discentes, a fim de saber se aqueles recursos ajudavam ou dificultavam a compreensão da matéria em exposição. E, diante dos 548 respondentes, quase $98 \%$ apresentam resposta afirmativa:

\begin{tabular}{l|l|l}
\hline Ajuda & 538 & $98,15 \%$ \\
\hline Dificulta & 4 & $0,72 \%$ \\
\hline Depende & 6 & $1,09 \%$ \\
\hline
\end{tabular}

Estas e outras respostas de semelhante diapasão permitem afirmar com razoável segurança que existe rentabilidade pedagógica quando se promovem determinados processos calcados nas possibilidades facultadas pelas novas tecnologias e pelas linguagens da comunicação mediada. Ou, de outra maneira, fica difícil trabalhar no território da educação formal sem a devida atenção para este mundo de dispositivos técnicos, aceleração do tempo, profusão de imagens, instantaneidade no acesso à informação, capacidade de registrar e colocar em circulação social eventos, ocorrências, acontecimentos.

5. Por este viés, quisemos saber dos professores como consideravam as interfaces dos meios e das linguagens da comunicação com a escola, se possuíam caráter complementar ou antagônico:

\begin{tabular}{l|l|l}
\hline Antagônica & 4 & $2,07 \%$ \\
\hline Complementar e antagônico & 5 & $2,09 \%$ \\
\hline Complementar & & $15894,6 \%$ \\
\hline
\end{tabular}


A maioria $(94,6 \%)$ dos docentes entende haver continuidade entre o discurso propriamente didático escolar e as linguagens institucionalmente não escolares. Ou seja, existe clara consciência acerca do necessário estreitamento dos diálogos entre comunicação e educação. Nota-se, comparando as pesquisas que vimos fazendo ao longo dos últimos anos envolvendo este âmbito educomunicativo, que não apenas diminuiu a resistência dos professores quanto ao tratamento dos temas, problemas, linguagens afeitas à comunicação, como se trata, agora, de trazê-los de modo mais decisivo para o ambiente escolar.

\section{Conclusão}

É perceptível para quem está voltado ao trabalho na interface comunicação e educação, ou educomunicação, conforme tratamento corrente em nossos dias, o fato de estarmos frente a problemas no âmbito das escolas que não se esgotam nos temas - certamente procedentes, em plena vigência e a serem urgentemente enfrentados, haja vista a dramática situação salarial e profissional dos docentes - ligados à infraestrutura e condições materiais do trabalho levado a termo pelos educadores. É imperioso dar tratamento prioritário a tais temas, sem o que fica cada vez mais difícil alcançar os objetivos de uma educação de qualidade.

O que se enunciou neste artigo é algo que não descurando dos óbices postos à educação formal, sobretudo aquela ligada à rede pública, busca ampliar o debate entendendo que existem mudanças culturais e de relações societárias promovidas pelo ecossistema comunicativo, cujo continuum não respeita os limites dos muros da escola. Os mecanismos de acesso à informação, a aceleração temporal, a presença das tecnologias digitais certamente estão trazendo outros desafios para as instituições educativas formais. E, conforme demonstrado nos dados da nossa pesquisa, os fluxos entre os mundos da comunicação, em seus aspectos múltiplos e diversificados, os ritmos da vida contemporânea, e os andamentos da educação, precisam ganhar movimento dialético, não por decorrência de modismos ou interesses de ordem mercantil e mesmo de publicidade governamental, mas porque novas configurações históricas estão a solicitar distintos mecanismos formativos cujos limites não cabem no enciclopedismo, no transmissivismo e no alheamento às reconfigurações sociotécnicas e tecnoculturais provocadas fortemente pelos sistemas e processos comunicativos. 


\section{Referências}

BAUMAN, Zygmunt. Desafios do mundo moderno. Rio de Janeiro: Jorge Zahar, 2015 .

BENJAMIN, Walter. Teses sobre filosofia da história. In: KOTHE, Flávio R. (Org.). Sociologia. São Paulo: Ática, 1985.

CITELLI, Adilson. Comunicação e educação. A Linguagem em movimento. São Paulo: SENAC, 2001.

Palavras, meios de comunicação e educação. São Paulo: Cortez, 2006.

CRARY, Jonathan. 24/7. Capitalismo tardio e os fins do sono. São Paulo: Cosac Naify, 2014.

GIACOIA JÚNIOR, Oswaldo. Ansiedade sem aplicativo. In: O Estado de São Paulo. 28/06/2015.

KLINENBERG, Eric. Going solo - The extraordinary rise and surprising appeal of living. London: Penguin Press, 2012.

LATOUR, Bruno. Reagregando o social. Bauru, SP: EDUSC/Salvador, BA: EDUFBA, 2012.

LIPOVETSKY, Gilles; SERROY, Jean. A cultura mundo, respostas a uma sociedade desorientada. São Paulo: Companhia das Letras, 2011.

REISMAN, David. A multidão solitária. São Paulo: Perspectiva, 1995.

ROSA, Hartmurt. Social acceleration. A new theory of modernity. New York:

Columbia University Press, 2013. 


\section{Comunicação e Educação: as distintas trajetórias no espaço ibero-americano ${ }^{1}$}

\section{Introdução}

$\mathrm{Na}$ investigação em comunicação e educação, tanto num plano nacional quanto internacional, há diferentes tradições teórico-metodológicas, o que não surpreende, visto que isto reflete as características dos campos mais amplos da comunicação e das ciências sociais. A diversidade também remete a diferentes tradições históricas que constituem o solo nas quais as práticas científicas se enraízam, com relação a contextos sociais e compreensões compartilhadas pelos pesquisadores dos diferentes locais.

Nesse sentido, tendo como objetivo geral compreender zonas de diálogo entre as perspectivas de investigação da comunicação e educação nos países da região ibero-americana, este texto procura delinear aspectos históricos conformadores da identidade dos estudos desta interface em países da América Latina e Europa.

Embora o estudo tenha viés historiográfico-documental, procura-se apontar o estado mais recente das discussões, pois é útil verificar o passado principalmente para pensar o tempo atual e o futuro do estudo da comunicação e educação na região ibero-americana.

1 Trabalho originalmente apresentado no GP Comunicação e Educação do XV Encontro dos Grupos de Pesquisa em Comunicação, evento componente do XXXVIII Congresso Brasileiro de Ciências da Comunicação, Rio de Janeiro, 2015. Texto atualizado para esta publicação.

2 Professor do Departamento de Comunicações e Artes da Escola de Comunicações e Artes da Universidade de São Paulo (CCA/ECA-USP).E-mail: richard.romancini@gmail.com. 
Uma questão ao mesmo tempo teórica e metodológica que merece esclarecimento é sobre o uso do termo "comunicação e educação". A terminologia que designa a interface em questão é representada também por outros neologismos, como educomunicação, ou outras combinações de palavras, como educação para os meios, literacia mediática, mídia-educação. Por vezes, estes termos podem remeter mais a alguns contextos geográficos do que outros; porém ao falar geralmente em "comunicação e educação" o que se busca é utilizar um termo "neutro", "guarda-chuva”, para diferentes perspectivas regionais.

Partindo da noção de "articulação" de Laclau e Mouffe - autores que usam o termo como um indicador de uma modificação identitária entre termos que se colocam em relação , Morabes e Martinez (2014) defendem que o vínculo entre comunicação e educação se processa dessa maneira. Este aspecto, com o qual se concorda, talvez seja o ponto principal que dê importância ao estudo dessa inter-relação. Duas dimensões centrais da sociabilidade e da formação se interpenetram-se na contemporaneidade e se reconfiguram-se, colocando desafios a comunicadores e educadores, bem além dos âmbitos que relacionam os meios de comunicação e as práticas escolares. De um ponto de vista estritamente pedagógico, a reflexão sobre a temática da comunicação e da educação se justifica, pois

Las nuevas relaciones sociales, cognitivas y simbólicas que han venido surgiendo a partir de la revolución comunicativa en estos últimos tiempos son un escenario de posibilidades que se presentan a la educación para generar un punto de intersección entre el mundo de lo cotidiano y el conocimiento. De esta manera, se logra reducir la brecha que existe entre la realidad que vive el alumnado, la estructura escolar y las demandas sociales del mundo de hoy (CUERVO SÁNCHEZ; MEDRANO SAMANIEGO , 2013, p. 128).

Nesse contexto - em que a ação educativa deve assumir que "está inmersa en un entramado comunicativo que surge conectado a una nueva manera de interacción entre lo abstracto, lo tangible y lo inteligible" (PALARÈS, 2014, p. 66) - tendências históricas são reposicionadas e as tradições de pesquisa e intervenção em comunicação e educação no espaço ibero-americano desenvolvem-se em novas direções.

\section{A comunicação e educação na região latino-americana}

O estado da arte sobre comunicação/educação realizado por Herrán (1999) tem ênfase na Colômbia; no entanto, traz dimensões histórias gerais 
de toda a região latino-americana. Assim, a autora observa que as desigualdades do modelo de desenvolvimento latino-americano, bem como as insuficiências dos sistemas educativos dos países da região e a rápida propagação de novas tecnologias, fizeram com que, a partir do final da década de 1970, houvesse um incremento de preocupações com a temática das relações entre as escolas e os meios de comunicação (HERRÁN, 1999).

É notável, porém, que no caso brasileiro as preocupações quanto às possibilidades de que os então novos meios pudessem significar um incremento e democratização da educação no país resultaram, bem antes, em projetos ligados ao rádio (como os de Roquette-Pinto, desde a década de 1920) e ao cinema educativo (novamente com participação de Roquette, dá-se a criação do Instituto do Cinema Educativo - INCE, em 1932). Tais experiências, no contexto brasileiro, mas provavelmente também em outros países da região, estiveram à frente de seu tempo, o que explica parte de seu insucesso.

Huergo (2007) percebe a "tecnificação" como estratégia de aumento de eficácia dos projetos educativos, dentro de um modelo desenvolvimentista de sociedade, que se forja na América Latina nas décadas de 1950 e 1960. Ela é uma forma inicial - e, segundo o autor, ainda hegemônica - de relacionar a comunicação e a educação nos países da região. Com efeito, o século XXI é marcado pela adoção de políticas públicas, em praticamente todos os países da região, que mesclam objetivos de inclusão digital e social, como o Projeto UCA (Brasil, 2009), Projeto Conectar Igualdad (Argentina, 2010) e o Plano CEIBAL (Uruguai, 2007), com forte componente tecnológico (ver uma análise comparativa dos projetos na América Latina em Finquelievich, Feldman e Fischnaller (2012).

Mas se a tendência de modernização tecnológica da educação, enfatizando o uso pedagógico dos meios, ainda se faz presente, ela não é a única vertente que caracteriza as relações entre comunicação e educação na América Latina. Na verdade, pode-se mesmo dizer que mais típica da região como um todo, com diferentes matizes entre os países, é a preocupação com o teor ideológico dos meios. Esta tendência se desenvolve desde pelo menos os anos 1960 e corresponde, tanto a uma disputa simbólica mais geral no contexto dos estudos em comunicação na região, quanto a situações sociopolíticas, como o desenvolvimento acelerado dos meios de comunicação e a ascensão das ditaduras militares.

O primeiro ponto (a relação geral com o estudo da comunicação) associa-se ao Centro Internacional de Estudios Superiores de Comunicación 
para América Latina (CIESPAL), que a partir de sua criação, em 1959, pela UNESCO, tornou-se um irradiador da perspectiva funcionalista nos estudos em comunicação na região. Instalado em Quito, Equador, essa instituição teve como missão inicial aprimorar o ensino de jornalismo, no entanto, ao longo do tempo, promoveu a discussão sobre a comunicação como elemento de modernização social. A temática da "extensão rural" (como meio de modernização de atitudes do homem do campo) aparece, então, a partir do final da década de 1960.

A ruptura com essa linha funcionalista do CIESPAL, por parte de acadêmicos locais, estabeleceu uma nova hegemonia e direção neste centro. Uma data que marca o novo direcionamento é 1973, quando, num Seminário na Costa Rica, explicitou-se a discordância com a linha inicial. Não por acaso, no único (e extraordinariamente influente) livro em que aborda diretamente a comunicação, Paulo Freire (1971) questiona a ideia de “extensão", promovida pelo CIESPAL e outros agentes, contrapondo-a a uma noção de “comunicação dialógica” e, por isso, participativa. As próprias metodologias criadas por Freire, no contexto da alfabetização - grupos de discussão e levantamento de "palavras-geradoras" - influenciaram o trabalho feito pelos comunicadores voltados à educação.

A aposta num processo de comunicação horizontal, pela via aberta por Freire, levava os estudiosos e praticantes da comunicação à desconfiança ou crítica aberta aos meios de comunicação de massa. Nos anos 1970, a perspectiva sobre a comunicação e educação combina-se ao pendor de denúncia do "imperialismo cultural" e da "manipulação de consciência” do campo comunicacional latino-americano da época.

As perspectivas críticas e ideológicas foram, em certa medida, também estimuladas por um panorama social em mudança, mas profundamente desigual e caracterizado pelo autoritarismo, que os próprios meios de comunicação favoreciam. Herrán (1999, p. 28) percebe, na primeira etapa da vertente ideológica, a importância do pesquisador Mario Kaplún, cujo trabalho "focaliza una visión ideológica, con estudios muy ligados a la teoría de la dependencia, a la visión marxista del problema: se analiza el mensaje y muy poco la forma, la técnica". O enfoque "ideológico" enfatiza, desse modo, o estudo da mensagem dos meios e seus elementos contextuais (propriedade, inserção econômica, etc.).

Dentro deste enfoque, dá-se também o desenvolvimento do trabalho com a comunicação e a educação popular, linha que adquire grande desenvolvimento, configurando uma vertente de "comunicação comunitária" ou 
"alternativa" bastante influenciada pela perspectiva aberta por Freire e pelas tendências ideológicas e seus desenvolvimentos. Barranquero (2006, p. 78) classifica a ampla gama de projetos e ações relacionados à ênfase mobilizatória, ideológica e crítica, como "comunicação/educação para a mudança social", notando positivamente que esta corrente colocou, de maneira pioneira, pela "primera vez la existencia de un continuum complejo, problemático y dinámico entre la comunicación y la educación”. Exemplos de projetos com esta perspectiva são as ações de "educação para os meios" ou "leitura crítica”, como a desenvolvida, a partir da década de 1970, pela União Cristã Brasileira de Comunicação Social (UCBC), no Brasil. Vale destacar a convergência desta proposta com a Teologia da Libertação, bastante influente em toda a América Latina na época. ${ }^{3} \mathrm{~A}$ visão ideológica que marca a trajetória da comunicação e educação na América Latina foi refinada pelas teorias e pesquisas sobre a recepção, durante a década de 1980. Desse modo, a onipotência dos meios foi questionada - embora as assimetrias de poder fossem ainda temas de discussão (pelas versões mais críticas) -, assim como o excessivo "basismo" ou a "fetichização do popular" de muitas ações (BARRANQUE$\mathrm{RO}, 2006$, p. 85). As propostas de "recepção ativa”, de autores como o mexicano Guilhermo Orozco Goméz e o chileno Valerio Fuenzalida, tiveram e ainda têm influência, induzindo a elaborações de pedagogias da recepção nas quais se considera bem mais o contexto sociocultural (as mediações) no qual se forja o sentido das mensagens massivas ou não. A televisão costumava ser o veículo sob mais escrutínio, por vezes com a preocupação de elaborar uma articulação entre pesquisa e ação social.

A comunicação de investigações e troca de experiência, durante a década de 1980, foi favorecida por uma série de encontros regionais, como os realizados pelo CENECA, desde 1985, no Chile, ou pela UCBC, em Curitiba, em 1986. Nessas ocasiões, documenta-se a mudança de enfoque por que passa a comunicação e educação na América Latina, de modo que, no primeiro seminário,

3 Neste caso, tratava-se de um programa de formação para agentes pastorais, religiosos, estudantes secundaristas, entre outros grupos, com ênfase na crítica dos conteúdos midiáticos. Iniciativas similares à da UCBC ocorreram em outros países da América Latina, na mesma época, realizadas por instituições como o Centro de Indagação, Expressão Cultural e Artística (CENECA) do Chile, o Centro de Investigação e Educação Popular (CINEP), na Colômbia, e o próprio CIESPAL (em sua fase mais crítica). 
los enfoques moralistas y denunciativos van dejando paso a propuestas más culturales y transformadoras, en coherencia con modelos comunicativos horizontales, propios de la educación popular. En esta línea [...], al final del Seminario se cuestionan: ¿como entender los procesos de recepción y las actividades resignificadoras que realizan los televidentes? (AGUADED, 1995, p. 27)

Os encontros regionais diminuíram na década seguinte, que contou, por outro lado, com encontros internacionais, como o Primeiro Congresso Internacional de Comunicação e Educação, que ocorreu em São Paulo, em 1998. Ainda sob o ponto de vista da institucionalização, Dalla Costa, Dias e Tomita (2014, p.10) defendem que a pesquisa em comunicação e educação na América Latina sofreu um processo significativo de institucionalização "entendida como a oficialização, seja acadêmica ou social, de propostas de educomunicação". Seguindo o movimento global, a pesquisa se torna menos politizada, e entre os indicadores da institucionalização, principalmente do caso brasileiro, estão aspectos ligados ao ensino com maior valorização de aspectos educomunicativos, a criação de uma associação nacional de profissionais e pesquisadores (ABPEducom) e a atuação de Organizações Não Governamentais. A interpretação dada aos indicadores, destacando o significado da menor politização, é a de que "os movimentos sociais entende[ra]m que o discurso contra a mídia deve ceder lugar a análises mais complexas que [sic] como as nuances culturais interferem no consumo midiático de um país multicultural como o Brasil" (DALLA COSTA; DIAS; TOMITA, 2014, p. 17).

Um desdobramento importante das experiências, verificado no Brasil, mas possivelmente também ocorrido em outros países da região, é apontado por Ismar de Oliveira Soares (2011), pesquisador brasileiro pioneiro na área e que tem procurado dar uma definição conceitual para a "educomunicação". Segundo o autor, a partir da década de 1990, núcleos de extensão universitários e ONGs passaram a difundir (e construir novas) metodologias relacionadas ao uso dos meios em experiências ligadas à educação para a mídia, sendo muitas destas ações ligadas também a ambientes formais, como escolas. Dá-se então, no Brasil, um conjunto de projetos, como o Educom. rádio (1999-2004), voltado a professores, estudantes e membros das comunidades escolares de escolas da cidade de São Paulo ou o Programa Mídias na Educação, promovido pelo Ministério da Educação, em diferentes estados do Brasil, desde 2005, diretamente preocupado com a formação de professores. Tais projetos impulsionam e dão novas direções à relação comunicação e educação na região. 
A preocupação com a formação professores e estudantes em relação aos meios de comunicação possui muitos outros projetos e se articula ao desenvolvimento de políticas públicas, como no caso do programa Escuela y Medios, do Ministério da Educação da Argentina (MORDUCHOWICZ, 2009). É possível que os sucessivos governos de tendência de esquerda na região tenham favorecido políticas públicas deste tipo, no entanto ações para a democratização da comunicação, como a Ley de Medios (2009) argentina, não têm sido a tônica da região. Isto implica limitações a muitos projetos em comunicação e educação, nos quais a questão do "direito à comunicação" é central. Na região, é notória a tendência ao monopólio dos meios. $4 \mathrm{De}$ qualquer modo, nos projetos governamentais, envolvendo as escolas, há uma aproximação com a noção de media literacy, na preocupação em desenvolver uma educação para os meios enquanto política de Estado, algo que parece se aproximar de preocupações europeias, como será visto.

Atualmente, os diagnósticos de muitos pesquisadores apontam para um momento social de mutação que implica a necessidade de novas reflexões e buscas. Huergo (2007, p. 44), por exemplo, notava que "las estrategias de comunicación en educación tienen que imaginarse a partir del reconocimiento de un mundo cultural complejo y conflictivo, como el que vivimos en América Latina”.

Orozco (2014), por sua vez, fala numa “condição comunicacional” que caracteriza nosso tempo e que constitui uma espécie de cenário para os educomunicadores; cenário que dá aos receptores a condição inédita de tornaram-se produtores criativos, ingressarem numa cultura de participação em relação às telas que veiculam o que consomem simbolicamente. Entretanto, isso representa uma nova tarefa para o campo da comunicação e educação.

Em linhas gerais, essa trajetória dos países latino-americanos quanto à comunicação e educação mostra, a despeito de especificidades de cada país, bastante homogeneidade e relativo diálogo entre os acadêmicos. Porém, é difícil dizer se continuará a haver unidade de perspectiva dado o momento atual de busca mencionado. Há fatores que podem contribuir com a unidade, como a memória comum e o fato de que instâncias de diálogo acadêmico (como congressos e eventos inter-regionais) e político (governos) já existem

4 Um exemplo das limitações dos governos de esquerda é o caso brasileiro, em termos do quão pouco se avançou nas legislações a propósito das rádios e outros meios de comunicação comunitários. 
e podem se desenvolver mais. Mas quanto ao diálogo com os outros países e particularmente com os da Europa Ibérica? Já existe certamente intercâmbio, no entanto, este pode ser incrementado com o melhor conhecimento da história e momento atual da região em termos do debate sobre a comunicação e educação. A este ponto se dirige o próximo tópico.

\section{A comunicação e educação na Espanha e Portugal}

Há também em Portugal e Espanha uma diversidade terminológica similar a que ocorre na América Latina, em relação aos termos utilizados para denominar o vínculo entre comunicação e educação. Desse modo, atualmente, na Espanha, segundo Lozano (2013), várias nomenclaturas são utilizadas: educación para los medios de comunicación, educomunicación, educación en los medios de comunicación, além da mais recente alfabetización mediática.

Desde cedo, houve diálogo entre as perspectivas de estudo e intervenção da América Latina e os países ibero-americanos, do que dá conta, por exemplo, o interesse dos pesquisadores, principalmente pelas atividades e perspectivas teóricas desenvolvidas por seus colegas americanos e a realização de encontros acadêmicos como o Seminário Internacional sobre "Educación y Medios de Comunicación en el contexto iberoamericano”, realizado na Universidade Internacional da Andaluzia, em 1995.

De acordo com Aguaded (1995, p. 37),

los orígenes de la Educación para la Comunicación en España, al igual que en otros países se remontan a las primeras experiências de la enseñanza del cine. La aparición de los cine-clubs fue el punto de partida de muchas iniciativas de introducción de los medios en las aulas, especialmente en esta época a través de la imagen cinematográfica.

O mesmo ocorre em Portugal, e em ambos os países também houve o desenvolvimento de atividades de imprensa escolar, por vezes a partir das experiências e discussões pioneiras de Freinet. No entanto, os trabalhos em comunicação e educação foram relativamente dispersos e de menor monta até a década de 1980, momento considerado um marco do desenvolvimento de esforços relacionados à comunicação e educação nesses países (AGUADED, 1995). Conforme o autor citado, neste momento, os principais suportes institucionais das experiências envolvendo a interface comunicação e 
educação foram as universidades, diferentes órgãos administrativos voltados à educação, os jornais nacionais e regionais e as ONGs. Apesar de crescente nos últimos anos, nota-se que a "trajetória de projetos relacionados à educação para os meios [media education] na Espanha não tem sido tão fértil ou ampla como em outros países, por isso, a consolidação desta área tem sido frágil e lenta" (GRANDÍO et al., 2014, p. 10).

Assim como na América Latina, houve e há o desenvolvimento de tendências mais preocupadas com a utilização dos meios de comunicação como tecnologias educativas do que como formas culturais e ideológicas. Desse modo, principalmente partindo da área educativa, a relação comunicação e educação tem sido estudada e praticada também sob esta ótica mais específica e preocupada com a melhoria da "qualidade" da educação e uso dos meios como recursos didático-pedagógicos. Isto estava em consonância, inclusive, com propostas de políticas estatais, como a Ley General de Educación, da Espanha, que, na década de 1970, dava um pioneiro apoio às experiências de educação com o uso de meios audiovisuais na escola.

A Lei Geral de Ordenação do Sistema Educativo na Espanha (LOGSE) também trouxe impulso à disseminação de projetos de educação com meios nas escolas durante a década de 1990, porém, "las instituciones educativas no han motivado un debate en torno a la integración de los 'nuevos y antiguos médios', habilitando un espacio para que la convergencia tecnológica tenga una presencia real en el aula" (GABELAS, 2007, p. 70).

$\mathrm{O}$ problema da formação dos professores, subjacente à citação anterior, também aparece em Portugal, a despeito do ambiente escolar ser um espaço privilegiado de atenção dos pesquisadores e das experiências em comunicação e educação realizadas. Outro óbice observado quanto à obtenção de maior espaço para educação para os meios, de acordo com Pinto (2003), é a herança de países que sofreram com regimes autoritários até certo ponto recentes, dificultando assumir o exercício crítico da mídia como uma prática democrática que promove a cidadania. Como não houve, ao contrário da América Latina, uma forte experimentação em mídia alternativa e/ou comunitária em Portugal e Espanha o terreno pós-democratização tinha que receber outro tipo de tratamento, e talvez por isso se explique a maior tendência à escolarização das práticas que envolvem a comunicação e educação.

A pesquisa acadêmica possui um pouco menos de tradição que na América Latina, embora seja crescente. Assim, Jones (2000), ao fazer um balanço da pesquisa em comunicação na Espanha, notava que o estudo da temática da comunicação e educação, apesar de citar alguns pesquisadores, 
tinha sido escasso até fins da década de 1990. De qualquer maneira, é possível notar um progresso na feitura de investigações que já possuem canais de veiculação consolidados, como a revista espanhola Comunicar, publicada desde 1994. Um balanço mais recente da produção científica sobre meios de comunicação e educação na Espanha (CÁCERES, 2006), no período 1996-2006, evidencia grande produção por parte dos pesquisadores da área de educação (metade das revistas deste levantamento é da mesma).

A preocupação com a televisão, e também outros meios, é marcante, associando-se com frequência à ideia de formar "receptores críticos", e em muitas investigações são construídas interfaces com temáticas de relevo social (estereótipos, educação para a cidadania e em valores, etc.), porém, para a autora do estudo, faltam trabalhos metodológicos. A presença da pesquisa voltada à tecnologia educativa (cerca de um terço da produção) é significativa, o que se relaciona ao panorama das tecnologias digitais e da "sociedade da informação". Embora seja necessária uma avaliação mais cuidadosa e amparada em dados, uma hipótese é a que existe certa semelhança, temática principalmente, entre a pesquisa sobre a comunicação e a educação nos dois lados do Atlântico.

Em Portugal, o impulso de modernização do país, desde a entrada do mesmo na União Europeia, em 1985, justifica uma série de projetos em tecnologia associados a objetivos educativos por parte do governo (COSTA; JORGE; PEREIRA, 2014), com um foco, principalmente, em ampliar o acesso a dispositivos. O advento da internet, ao mesmo tempo, reforça tendências tecnocêntricas na educação para os media em Portugal, segundo Pinto (2003), abrindo espaço tanto para orientações reticentes às tecnologias quanto para os defensores das novas tecnologias. Ambas as perspectivas são caracterizadas pelo determinismo que marca os programas que buscam promover e difundir as novas tecnologias na escola para estimular a inovação educativa. Esta dimensão, na sua vertente otimista, está em consonância com discursos emanados por organizações europeias que têm cada vez mais influência nos países ibero-americanos e em seus Ministérios da Educação.

A propósito da situação espanhola, existem indicadores similares. Pegurer e Martinez (2014) notam que a educação midiática aparece de maneira apenas implícita no currículo escolar espanhol, e a Lei Orgânica 8/2013, para a Melhora da Qualidade Educativa (LOMCE), que poderia ser uma oportunidade de avanço a propósito da comunicação e educação, não aborda o tema nenhuma vez. A ênfase é colocada nas Tecnologias de Comunicação e Informação, sendo introduzida também uma disciplina de "Cultura Audiovisual”. "Tanto no âmbito curricular como nas políticas 
educativas em geral, o que se pode notar com relação à Espanha é uma ênfase à introdução das TIC, bem como o desenvolvimento às competências necessárias para manejá-las" (PEGURER; MARTINEZ, 2014, p. 759). Por outro lado, Pérez-Tornero e colaboradores (2010) veem um movimento europeu no qual a preocupação com o letramento digital (digital literacy) dá aos poucos lugar à educação midiática (media literacy) nas iniciativas e projetos. Desse modo, o foco estaria menos nas TIC ou na mídia do que nos usuários.

Falando do contexto europeu, um aspecto notável em ambos os países ibero-americanos é o impulso que as iniciativas do continente relacionadas ao desenvolvimento da "educação para os media" (media education) têm no panorama mais recente, das últimas décadas, de discussão envolvendo a comunicação e a educação. Isto envolve a inserção em espaços de debate europeus, com adoção de uma agenda de preocupações comuns, a participação em estudos comparados e a tentativa de influenciar/formular políticas públicas que superem a fragmentação e a descontinuidade que caracterizaram muitas ações do passado. A conceitualização adotada, em torno da noção de media literacy e media education, tende também a reforçar certa unidade, diminuindo a imprecisão conceitual e falta de entendimento sobre os objetivos teórico-pedagógicos da educação em meios que para alguns autores caracterizam a situação ibérica (MARGALEF, 2010). ${ }^{5}$

O exemplo europeu fornece modelos de ação inovadores, como na articulação entre organismos de regulação e ações de educação para os meios - caso da ação dos Conselhos Audiovisuais das regiões autônomas da Espanha, que começam a surgir a partir dos anos 2000, possuindo alguma similaridade com o órgão regulador do Reino Unido (OFCOM) (CAMPS, 2009).

O impulso europeu, aparentemente, tem feito também com que, no âmbito interno dos países, se dinamizem ações voltadas à pesquisa, como pode ser exemplificado pela realização de eventos nacionais ou internacionais, como os congressos bianuais de "Literacia Mediática, Mídia e Cidadania”, o primeiro foi em 2011, em Portugal, realizado por um coletivo informal

5 Numa definição comum, adotada na Europa a partir de discussões no âmbito da UNES$\mathrm{CO}$, a media literacy "é o termo que descreve as habilidades e competências necessárias para criar, com autonomia e consciência, no novo ambiente comunicativo - digital, global e multimídia - da sociedade da informação" (PÉREZ-TORNERO, 2007, p. 10). Do processo de media education resulta a media literacy. 
de organizações e o "Congreso de Educación Mediática y Competencia Digital”, também realizado pela primeira vez em 2011, em Segóvia, na Espanha, contando com a organização de uma série de instituições, como a Universidade de Valladolid, o Grupo Comunicar, de Huelva, e o Ministério da Ciência e Inovação.

A própria legislação dos países, como acontece em Portugal, ou a atitude de muitos estudiosos a respeito de como a comunicação/educação deve se articular com a escola parece sofrer influência das posições europeias, ou seja, defende-se bem mais agora a inserção de matéria (ou matérias) específica e obrigatória sobre a temática nos currículos da educação (em todos os níveis) do que somente o trabalho transversal com a temática. A abordagem transversal, em termos escolares, embora tenha diversos defensores dos dois lados do Atlântico é afetada pelo “escepticismo dado el fracaso experimentado por las escuelas ante la iniciativa de introducir en el proyecto docente conocimientos transversales" (CAMPS, 2009, p. 141). Outra crítica é quanto à indefinição teórica da transversalidade da educação em meios, o que fez com que os currículos se limitassem a notar a importância de incorporar as mídias como elementos auxiliar, mas sem prestar maior atenção a como desenvolver a capacidade crítica dos alunos frente aos meios, ao que se acrescenta o problema prático de que, na educação escolar, se exigiria a formação de todos os professores no assunto, conforme Margalef (2010).

Por outro lado, certas ações sociais, particularmente com empresas ou organizações da sociedade civil, tentam ampliar os segmentos envolvidos com a educação para os meios, caso, por exemplo, do projeto português Media Lab, apoiado por dois jornais privados e que oferece workshops também a pessoas de mais idade. Aparentemente, em termos comparados e de escala, os países ibéricos contam com maior número de iniciativas com parecerias deste tipo. Porém, no contexto europeu, assim como no Brasil, talvez exista atualmente um direcionamento bem maior ao ambiente escolar ou iniciativas em ações de educação não formal para jovens do que para a sociedade como um todo.

A preocupação com a avaliação das ações/projetos e com a produção de indicadores a propósito do estado do tema na educação formal ou na população em geral é outra temática que ganha corpo em Portugal e na Espanha, a partir da discussão europeia. A noção de “competência” migrou do campo educativo ou formativo para ações de comunicação e educação, com desdobramentos ainda não totalmente percebidos. 


\section{Considerações finais}

Os estudos comparativos sobre a realidade da América Latina e dos países ibéricos quanto à comunicação e educação são relativamente escassos. Uma exceção é o trabalho de Zanchetta (2009), que analisa o tratamento da mídia na educação dentro da proposta europeia (PÉREZ-TORNERO, 2007) e seu kit educativo associado, produzido pela UNESCO para discutir sua aplicabilidade na escola brasileira. De acordo com o autor referido, o relatório e as ações europeias tendem a eleger a escola como o espaço preferencial das ações voltadas à educação para os meios, porém, há pouco detalhamento sobre a formação para que os professores enfrentem o conjunto de conhecimentos (e sua articulação) em relação a questões bastante diversas (política, economia, linguagem, etc.). Esse é um ponto, a despeito de avanços dos últimos, conforme as descrições anteriores, que provavelmente precisa, de fato, ter mais amadurecimento em todo o mundo.

Zanchetta (2009) também mostra uma diversidade de agentes (órgãos reguladores, canais públicos e privados de informação) fora dos limites da escola que poderiam, com alguma articulação, se não ocupar totalmente o espaço desta instituição, representar um âmbito formativo importante no contexto europeu.

No nosso entender, esses são aspectos - com angulações um tanto diferentes - mostram alguma similaridade entre América Latina e Europa (países ibéricos inclusive). Embora a trajetória latino-americana tenha enraizamento fora do espaço escolar, hoje, a escola tende a ser a instituição que catalisa esforços. E há bons motivos para isso, como o fato destacado pelo próprio autor (ZANCHETTA, 2009) de que a comunicação é dominada pela mídia privada na região latina, de modo que o papel dos professores e da escola ganha relevo. A concentração dos veículos prejudica possibilidades mais amplas de participação, assim como os contrapontos avaliativos, que favorecem a reflexão, são menores. É claro, há também no contexto latino-americano diversidade de agentes, mas o papel governamental e de um sistema público de informação parece ser mais decisivo pelo que se disse.

Igualmente, relevante é o fato de que perspectivas latino-americanas mais recentes, que buscam favorecer a autonomia do receptor, possuem similaridade com perspectivas europeias. "A Educomunicação, por exemplo, avizinha-se da perspectiva de David Buckingham [...] em diversos pontos, como na ênfase à cultura autônoma desenvolvida pelos jovens a partir do contato 
com a mídia e com os próprios pares" (ZANCHETTA, 2009, p. 1.114). Aqui se coloca uma questão de interesse de avanço nos estudos comparados: em que medida as possíveis confluências teóricas ocorrem?

Seria interessante, pois, finalizar o artigo menos com declarações do que com indagações. Assim, certas comparações entre as realidades estudadas são anotadas a seguir, destacando eixos de maior similaridade ou diferença que podem ensejar diálogos:

\section{Diferenças contextuais}

A relação entre avaliação e as iniciativas em comunicação e educação é uma preocupação mais europeia do que latino-americana. Quais as potenciais vantagens e desvantagens desta preocupação (ela não pode, por exemplo, constranger a criatividade das iniciativas ou limitar as ações a dimensões mensuráveis e já tradicionais no ambiente escolar)?

Também parece haver maior número de projetos na Europa associados a empresas privadas, o que coloca a questão (também existente na América Latina, mas em menor grau) sobre as diferentes agendas das instituições do campo público e privado. Como se tem buscado construir convergências e acordos desse tipo na Europa (mas também na América Latina)? O que as realidades dos diferentes contextos podem ensinar?

A situação europeia é mais avançada quanto à articulação entre a regulação democrática dos meios de comunicação (por exemplo, os Conselhos Audiovisuais da Espanha) e as propostas de desenvolver a educação para os meios. Por outro lado, na América Latina (Brasil e Argentina, em particular) as políticas tem se voltado ao tema, mais além dos marcos educacionais. Quais os ganhos que têm sido obtidos com essas ações e políticas e como podem ser intercambiados entre os países da região?

A introdução de disciplinas específicas voltadas à comunicação e educação parece prevalecer na Europa, diferentemente da América Latina. O que a experiência europeia ensina sobre o assunto até o momento? E quais os desafios na formação do profissional para essas atividades pedagógicas de teor formal? A Europa encaminha-se para formar também (caso do Brasil) "educomunicadores" em licenciaturas ou a formação/perfil profissional será diverso? 


\section{Confluências}

Múltiplos atores têm se envolvido com as atividades de comunicação e educação em ambos os contextos. Qual a relação entre transferência de conhecimentos em relação os âmbitos sociais que se envolvem no trabalho com a comunicação e a educação na Europa e América Latina.

A tensão (ou separação) das perspectivas tecnológicas e as de maior pendor analítico e crítico são comuns à América Latina e Europa em termos do estudo e prática da comunicação e educação. Existem possibilidades de diálogo ou zonas de contato e sinergia entre essas tendências?

O maior foco de preocupação em ações nas escolas, comum tanto na Europa quanto na América Latina, possui a vantagem de buscar preparar as gerações futuras melhor, no entanto, também tendem a deixar fora das ações muito segmentos sociais. Quais as possíveis estratégias para envolver a sociedade de maneira mais geral - um conjunto de ações, iniciativas mais globais ou ambos? 


\section{Referências}

AGUADED GÓMEZ, J. I. La Educación para la Comunicación. La enseñanza de los medios en el contexto iberoamericano. In: AGUADED GÓMEZ, J. I.; CABERO ALMENARA, J. (dir.). Educación y Medios de Comunicación en el contexto iberoamericano. Universidad Internacional de Andalucía, 1995· p. 19-48.

BARRANQUERO, A. Comunicación/educación para el desarrollo en Latinoamérica. Memorias de una fértil confluencia. Revista de Economía Política de las Tecnologías de la Información y Comunicación, v. VIII, n. 3, sep - dic. 2006.

CÁCERES ZAPATERO, M. D. Comunicación y Educación: Un balance cualitativo. ICONO, v. 14, n. 72006.

CAMPS, V. La educación en medios, más allá de la escuela. Comunicar, 32, XVI, p. 139-145, 2009 .

COSTA, C.; JORGE, A.; PEREIRA, L. Media and Information Literacy Policies in Portugal (2013). First European Media and Information Literacy Forum. UNESCO, Paris, May 27 and 28, 2014.

CUERVO SÁNCHEZ, S. L.; MEDRANO SAMANIEGO, C. Alfabetizar en los medios de comunicación: más allá del desarrollo de competencias. Teor. educ., v. 25 , n. 2, p. 111-131, 2013.

DALLA COSTA, R. M. C.; DIAS, L. O.; TOMITA, I. Y. A institucionalização da pesquisa na interface comunicação-educação. ALAIC, GT4: Comunicação e Educação, 2014 .

FINQUELIEVICH, S.; FELDMAN, P.; FISCHNALLER, C. Public Policies on Media and information literacy and education in Latin America: Overview and Proposals. International Conference "Media and Information Literacy in Knowledge Societies”. Moscow, 24-28 June 2012.

FREIRE, P. Extensão ou comunicação? Rio de Janeiro: Paz e Terra, 1971.

GABELAS BARROSO, J. A.. Una perspectiva de la educación en medios para la comunicación en España. Comunicar, 28, 2007. 
GRANDÍO PÉREZ, M. del M.; VICENTE, M.; GARCÍA MATILLA, A.; GUTIÉRREZ MARTÍN, A.; MARTA LAZO, C. Media and Information Literacy Policies in Spain (2013). First European Media and Information Literacy Forum. UNESCO, Paris, May 27 and 28, 2014.

HERRÁN, M. T. Pistas para el encuentro Comunicación/Educación. In: HERRÁN, M. T.; MARTÍN-BARBERO, J.; ZAMBRANO, M. F. Palimpsestos y recorridos de la comunicación en la educación. Bogotá: Universidad Pedagógica Nacional, 1999. p. 13-175.

HUERGO, J. La comunicación en la educación: Coordenadas desde América Latina. FISEC-Estrategias - Facultad de Ciencias Sociales de la Universidad Nacional de Lomas de Zamora, Año III, n. 7, p. 35-52, 2007.

JONES, D. E. Investigaciones en España sobre la comunicación iberoamericana. PCLA, v. 1, n. 3, abr./mai./jun. 2000.

LOZANO ESTIVALIS, M. Educomunicar: ¿de qué estamos hablando? El debate epistemológico de la educación en materia de comunicación. II Congreso Internacional Educación Mediática \& Competência Digital. Barcelona, 14 y 15 de Noviembre de 2013.

MARGALEF MARTÍNEZ, J. M. Retos y perspectivas de la educación mediática en España. Consulta a expertos. Madrid: Ministerio de Educación, Subdirección General de Documentación y Publicaciones, 2010.

MORABES, P.; MARTÍNEZ, D. Problemáticas emergentes y líneas de investigación en comunicación/educación: algunas reflexiones iniciales ante la implementación de políticas públicas de inclusión educativas en Argentina. ALAIC, GT4: Comunicação e Educação, 2014.

MORDUCHOWICZ, R. Cuando la educación en medios es política de Estado. Comunicar, 32, XVI, p. 131-138, 2009.

OROZCO GÓMEZ, G. Educomunicação: recepção midiática, aprendizagens e cidadania. São Paulo: Paulus, 2014.

PALARÈS PIQUER, M. El legado de Paulo Freire en la escuela de hoy. De la alfabetización crítica a la alfabetización en medios de comunicación. Teor. educ., v. 26 , n. 1, p. $59-76,2014$. 
PÉREZ-TORNERO, J. M. et al. Trends and models of media literacy in Europe: between digital competence and critical understanding, Anàlisi 40, p. 85-100, 2010.

PÉREZ-TORNERO, J. M. (org.). Study on the Current Trends and Approaches to Media Literacy in Europe, European Commission, 2007.

PEGURER CAPRINO, M.; MARTINEZ CERDÀ, J. F.. Políticas e indicadores de educação midiática no contexto Ibero-americano: Brasil, Portugal e Espanha. In: MARTINS, M. de L.; OLIVEIRA, M. (ed.) Comunicação ibero-americana: os desafios da Internacionalização. Braga: Centro de Estudos de Comunicação e Sociedade, Universidade do Minho, 2014. p. 757-767.

PINTO, M. Correntes da educação para os media em Portugal: retrospectiva e horizontes em tempos de mudança. Revista Iberoamericana de Educación, Madrid, n. 32, maio-ago. 2003.

SOARES, I. de O. Educomunicação: conceito, o profissional, a aplicação - contribuições para a reforma do Ensino Médio. São Paulo: Paulus, 2011.

ZANCHETTA JR, J. Educação para a mídia: propostas europeias e realidade brasileira. Educ. Soc., Campinas, v. 30, n. 109, p. 1103-1122, Dec. 2009. 


\section{Comunicação e Educação: convergência e imagens como meios de campo}

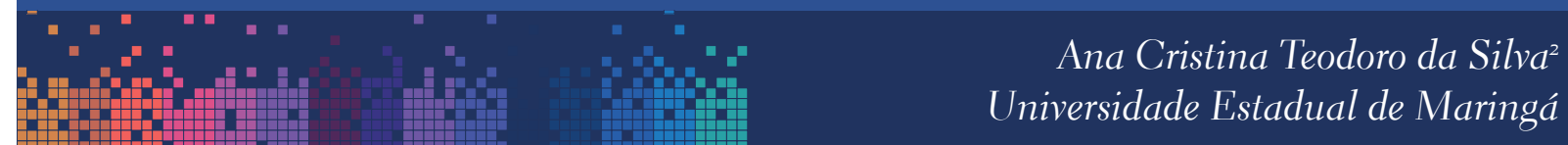

As gerações mais jovens têm os dispositivos móveis como extensões do corpo, como meios de comunicação e conexão, e esse hábito influencia os modos de aprender, as expectativas, os valores. A acessibilidade fácil dos conteúdos em rede gera a ilusão de que todo o conhecimento acumulado pelos homens está ao alcance das mãos. Ao mesmo tempo, a interatividade nas redes sociais gera um ambiente nunca visto, com possibilidades a serem exploradas. Estamos em momento de experimentação e criação a respeito dos significados das convergências de meios e conteúdos para a cultura e a política.

A proposta é apresentar duas perspectivas que podem parecer um tanto contraditórias, mas que devem conviver. Em uma delas, discussões a respeito da convergência, considerando-a, para além de fenômeno tecnológico, um arranjo cultural. Henry Jenkins (2009), inspirado em Pierre Lévy, percebe alto potencial na constituição de uma inteligência coletiva que pode, inclusive, inspirar novas posturas políticas. Na outra, o alerta para o excesso de luz da atualidade, em outros termos, excesso de telas que, de acordo com Norval Baitello Junior (2014), distancia-nos de nossos corpos, corpos que têm sido mera aparência; somos devorados pelas imagens e tornamo-nos cegos às sombras, à interioridade.

Uma aluna disse-me que os professores são presunçosos. Querem que os estudantes prestem atenção apenas neles, enquanto essa geração seria capaz de fazer mais de uma coisa ao mesmo tempo. Ela não está desprovida

1 Trabalho originalmente apresentado no GP Comunicação e Educação, XV Encontro dos Grupos de Pesquisas em Comunicação, evento componente do XXXVIII Congresso Brasileiro de Ciências da Comunicação. Texto atualizado para esta publicação.

2 Professora do curso de Comunicação e Multimeios, Doutora em História, Departamento de Fundamentos da Educação da Universidade Estadual de Maringá (DFE/UEM). 
de razão, existem diferentes perfis de leitores ${ }^{3}$. As tecnologias contemporâneas parecem contribuir para que o indivíduo esteja atento a diferentes mídias ao mesmo tempo, televisão e computadores ligados, celular ao lado, um fone no ouvido, tal multifunção é uma habilidade. Outro perfil seria o do leitor concentrado em uma narrativa, quem sabe na linearidade de um livro, ordenado e metódico, perfil constituído historicamente. A disciplina de ler textos escritos foi aprendida em um processo e tornou-se ícone de estudo e erudição ${ }^{4}$.

Não é adequado incensar as novas gerações e as "novas" tecnologias, como se tivessem habilidades mágicas que resolverão todos os problemas, como se fossem autônomas e pudessem abrir mão dos processos tradicionais de aprendizagem. Tampouco é adequado fechar os olhos às relações atuais com dispositivos móveis em rede, geradores de comunicação e incrivelmente facilitadores do acesso aos mais distintos arquivos. O professor depositório de saber que o transmite a incautos alunos não tem mais cabimento.

Precisamos pensar em nossa situação atual para além de dicotomias estanques, mantendo a dúvida, se for o caso, mas sem abrir mão de reconhecer os problemas.

\section{Mídias móveis e educação - problematizações}

Crianças e adolescentes têm associado acesso pleno à internet por meio de dispositivos individuais com liberdade, sentem-se livres com seus telefones celulares, utilizando aplicativos e redes sociais. Porém, têm comportamentos bastante parecidos entre si, tendendo ao estereótipo. São controlados por seus grupos. Cobram privacidade dos responsáveis, mas não percebem o controle do grupo, ou dos grupos formados em seus aplicativos ou redes sociais. ${ }^{5}$ São controlados pelo grupo na medida em que os grupos dão o compasso do que fazer e como fazer, do que é bonito, esperto, engraçado, como, de resto, é normal em grupos jovens. A escola na qual vivemos tem

3 Para reflexões sobre os diferentes perfis de leitores jovens e suas conseqüências, ver "Navegar no ciberespaço: o perfil cognitivo do leitor imersivo”, de Lucia Santaella (2004).

4 Para a construção histórica da leitura, consultar obras de Roger Chartier.

5 Devo esse raciocínio à professora Aline Frollini Lunardelli Lara, em uma produtiva manhã de trabalho. 
por premissa o estudo disciplinado e focado, pelo que a instituição tem sido bastante criticada desde, pelo menos, os anos 1960. As críticas, com muita razão, apontam que a instituição produz sujeitos cordatos e enquadrados. Em momentos de ditadura militar, fundamentalismo religioso no caso do ensino confessional, de qualquer autoritarismo ou predomínio ideológico, tais críticas são essenciais. Mas talvez estejamos preparados para pensar até que ponto a escola pode abrir mão da valorização da disciplina de estudo e da concentração focada em um texto, autoritarismos certamente à parte.

Qual é o fundamento ideológico da escola hoje? Minha hipótese é: o capitalismo. Vivemos em uma sociedade de mercado, em que crianças e jovens são educados para serem bem sucedidos no "mercado de trabalho". Ter sucesso na vida a maioria das vezes é entendido como ganhar dinheiro, e esse é o fundamento do que se espera das escolas, um público trabalhador habilitado, consumidores mais potentes. Na universidade, internamente reproduzimos a lógica capitalista com muita competição e produtivismo, dos graduados se espera uma maior competência no âmbito do mercado.

Qual perfil de estudo e leitura pode produzir crítica, questionamento? Qual perfil é adequado à sociedade competitiva e veloz na qual estamos? De que Educação falamos?

Percebo, em sala de aula, que é comum os alunos conectados por seus celulares repercutirem os temas apresentados em sala nas redes sociais. Tanto checam os dados que o professor diz como postam comentários, críticas, ironias em grupos constituídos em aplicativos como o WhatsApp. Acontece, em uma aula ou evento, que alguns alunos conversem entre eles em um grupo fechado pela internet, preferindo essa fofoca. Porém, com isso, suas inquietações, dúvidas e críticas não são apresentadas no debate presencial da turma, em prejuízo desse excelente exercício dialógico. O aluno, a maior parte das vezes, não treina expor, em público e presencialmente, na presença de pelo menos um adulto, seu ponto de vista, para que ele seja debatido ou desdobrado. Expor-se presencialmente mostra a necessidade de expressão em linguagem aceita em ambiente de aula, expondo-se também às críticas dos professores e dos colegas. Ocorre, sem dúvida, o pudor da exposição, pudor que, até certo ponto, filtra pensamentos inapropriados, como os sexistas ou racistas. Os ambientes de redes sociais são livres e sem esse parâmetro crítico, dissolvendo a seriedade fundamental à aula.

Hoje, os pequenos intervalos de saída e chegada de qualquer lugar, antes e depois das refeições, depois do cinema, enfim, qualquer "tempinho", pode ser preenchido pela verificação das mensagens no celular. Sem contar 
as ansiosas checagens em meio a espetáculos, em meio às refeições. Não vou considerar a falta de polidez básica de muitos, que priorizam, escancaradamente, a extensão celular ao contato com quem se faz uma refeição, com quem se caminha. O que perdemos? O que fazíamos antes nestes intervalos? Olhávamos em volta, pensávamos no filme?

Professores têm reclamado, no contexto universitário, da falta de participação dos alunos e de falta de interesse. O que destaco aqui não explica a apatia e desinteresse, mas faz parte do quadro que encenamos. Alguns alunos canalizam suas energias expressivas para as redes sociais, sem críticas de professores (e, em casa, dos responsáveis, quem sabe), e perdem a chance do debate cara a cara, que nos treina para incontáveis situações democráticas. Treina para ouvir, treina para falar, treina para as diferenças, treina para o respeito às autoridades, no caso, do conhecimento. Há quase 60 anos, Hannah Arendt apontava nossa dificuldade em diferenciar autoritarismo de autoridade e cravava: quem quer ser pai, mãe, professor ou professora, deve assumir responsabilidades pelas gerações futuras. As instituições família e escola são transmissoras de cultura, de ciência, somos ponte para um saber acumulado, temos a autoridade do passado de nosso grupo que precisa ser aprendido pelos jovens (ARENDT, 1992). Essas instituições parecem estar em crise, e isso é muito interessante, mas que faremos durante essa transição? Para que transitamos? De novo, qual é nosso sonho?

Não trato aqui de ambientes escolares autoritários, nos quais os alunos não podem falar. Minha experiência refere-se a alunos de graduação, na faixa etária prioritária entre 16 e 20 anos, em ambiente de universidade pública, em uma cidade média, Maringá, sul do Brasil.

O tempo é fundamental na resposta a estímulos. Responder a um e-mail no mesmo momento, com raiva, enviá-lo, e arrepender-se depois do dedo ter pressionado a tecla enter. Quem não passou por isso? Muito distante do tempo da espera da carta, de sua leitura, do tempo da resposta, de levá-la ao correio, caminho no qual muitas cartas eram desvirtuadas, alteradas, caminho que dava outro tempo ao pensamento, ao arrependimento ou ao pudor.

As redes sociais favorecem uma temporalidade em que não se perde a piada, responde-se imediatamente e "no mesmo tom". O imediato e fácil não combina com reflexão, com posicionar-se no lugar do outro, com experimentar emoção e aprender com ela, antes de retrucar. O trânsito das cidades é outra metáfora de nossas ações diferentes em diferentes ritmos, de como somos levados pelo fluxo, e como ficamos reativos, defensivos, até mesmo violentos. 
Não sou nostálgica, mas resolvi aqui demarcar o que estamos perdendo, em contraposição à ideologia de que o novo é melhor, de que mais rápido é melhor, de que a nova tecnologia é sempre avançada.

Outro aspecto: o uso dos celulares e computadores como arquivos.

É comum termos arquivos de músicas, de fotografias, de vídeos, de filmes. Mas todo arquivo precisa de sistematização; caso contrário, seus elementos não podem ser acessados. As gerações recentes comumente não escutam muito da mesma música, escutam poucas vezes muitas músicas. O momento da escuta costuma ser também multimeios, junto com a caminhada, com o estudo, com a televisão ou computador.

Fotografias temos milhares, mas quem volta às pastas de imagens das últimas férias? Fotografia na atualidade é, muitas vezes, o compartilhamento de uma representação idealizada de uma experiência: o que se come, o marco de um lugar em uma selfie, a diversão em grupo sorridente. E o compartilhamento necessita ser no agora, como a dizer: estou me divertindo neste momento, e você?

Poucos alunos usam cadernos e anotam. Sobre as carteiras, os celulares, com os quais tiram fotografias das datas de avaliações escritas no quadro. As anotações têm função mnemônica, de reflexão. As imagens feitas sem esforço vão para o arquivo. No arquivo, nas nuvens (!), há tudo, e na cabeça? E o exercício mental? As tecnologias atuais possibilitam uma quase infinita capacidade de arquivo, mas arquivo não é conhecimento, não é reflexão, não é capacidade de conexão. E mais: estes arquivos são codificações digitais, o que significa dependência de aparatos mecânicos e elétricos, que por sua vez dependem de manutenção e fontes energéticas. Sem dúvida representam acúmulo de informação, mas informação não é conhecimento. Ou, pelo menos, devemos perguntar qual a aprendizagem resultante desse processo.

\section{Inteligência coletiva e cultura da convergência - potenciais}

O livro Cultura da Convergência, de Henry Jenkins, é visto por alguns como o livro do momento, que todos devem ler para entender os fenômenos transmídia. $\mathrm{O}$ autor procura relacionar três conceitos: convergência dos meios de comunicação, cultura participativa e inteligência coletiva.

A convergência não depende de qualquer mecanismo de distribuição específico. Em vez disso, a convergência representa uma mudança de 
paradigma - um deslocamento de conteúdo de mídia específico em direção a um conteúdo que flui por vários canais, em direção a uma elevada interdependência de sistemas de comunicação, em direção a múltiplos modos de acesso a conteúdos de mídia e em direção a relações cada vez mais complexas entre a mídia corporativa, de cima para baixo, e a cultura participativa, de baixo para cima. Apesar da retórica sobre a "democratização da televisão", essa mudança está sendo conduzida por interesses econômicos e não por uma missão de delegar poderes ao público ${ }^{6}$ (JENKINS, 2009, p. 325).

É fundamental entender que a convergência não ocorre nos aparelhos, nas tecnologias, ocorre na mente das pessoas, ou dos consumidores individuais e em suas interações sociais. Jenkins é claramente contrário à ideia de que a convergência é um processo principalmente tecnológico.

Percebe que vemos as mudanças relativas às mídias contemporâneas como mudanças tecnológicas. Elas não são fundamentalmente tecnológicas, mas sobretudo culturais. É na cultura que devemos procurar a lógica e as consequências dos processos que vivemos.

Fundamentado em Pierre Lévy, Jenkis entende como inteligência coletiva a capacidade das comunidades virtuais de disponibilizar a todos os conhecimentos de cada um dos membros. Sozinho, ninguém sabe muito, o conhecimento está na humanidade. A inteligência coletiva questionaria qualquer tipo de hierarquia com sua dinâmica falta de regras e desorganização.

É necessário levar em conta o risco de observarmos como gerais tendências que são de uma elite de desbravadores. No caso das análises de Jenkins, a elite branca dos Estados Unidos. No Brasil, propomos que os modismos relativos aos usos das novas tecnologias partem de adolescentes, não lhes sendo exclusivos. As expectativas dos alunos universitários seriam iguais nos turnos matutino, vespertino e noturno, sendo que à noite o público trabalhador é maior?

Tratando do filme Matrix como exemplo de narrativa transmídia, o autor afirma que o padrão de narrativa dos filmes de Hollywood dependia da redundância, as histórias precisavam ser narradas de modo encadeado, coeso. Em Matrix, temos que manter os olhos atentos o tempo todo e fazer pesquisa antes de ir ao cinema. É uma narrativa paradigmática de diversas mensagens e linguagens ao mesmo tempo.

6 Ver também as definições de convergência que se encontram às páginas 29 e 377. 
O fenômeno Harry Potter mostra como as crianças podem participar da cultura da convergência. Na internet, em diversos grupos de discussão e redes sociais, cada indivíduo ou nó da rede une seu conhecimento ao de outros em empreitada coletiva; compartilha e compara valores avaliando dramas éticos; forma conexões entre pedaços espalhados de informação; expressa interpretações e sentimentos; circula criações; interpreta papéis... Jenkins (2009) chama a atenção que esse resultado só é possível por meio de participação ativa.

O conhecimento é partilhado e a atitude crítica é contínua. Estamos diante de um paradigma que necessita ser assimilado pelos processos pedagógicos institucionais? Nossa escola está fora de seu tempo?

Jenkins (2009) trata de uma nova cultura política. E se as pessoas aplicassem as habilidades de fãs em suas responsabilidades civis? Imaginem, nas eleições, a inteligência coletiva juntando dados sobre os processos e candidatos, disponibilizando-os a todos e gerando discussão. No Brasil, qual público seria atingido e participaria? E de que forma?

Contudo, necessitamos urgentemente de criação na política, estamos em um círculo vicioso, os partidos no poder não se movem para a reforma política necessária, tampouco tiveram a dignidade de planejar uma educação de qualidade, em mais de vinte anos de governos de centro-esquerda. Como melhorar nossa representação política? Transformar a política em um tipo de cultura popular não seria uma alternativa? Segundo Jenkins (2009), o poder emergente de participar serve como corretivo às tradicionais fontes de poder.

As comunidades de fãs analisadas produzem e fazem circular novas ideias a partir de leitura crítica de seus textos favoritos. Realiza o acesso à estrutura da inteligência coletiva e a uma modalidade de cultura participativa. Quais são os efeitos políticos? Jenkins (2009) se vê como utópico crítico, sugere promover potenciais, em vez de rejeitar de imediato o que parece inesperado.

Não poderíamos, professores, cientes desses potenciais e processos, tentar explorar o poder relacionado às mídias em nossos objetivos? Para o autor, seguindo Pierre Lévy, trata-se de uma "utopia realizável” para a qual devemos estar atentos às dimensões éticas consequentes de nossos modos de produzir conhecimento, cultura e política.

\section{Imagens e temporalidades - crítica}

Uma outra perspectiva é oferecida pelo pensamento de Norval Baitello Junior, e interessa o exercício de posicioná-la paralelamente para ampliar 
a reflexão. Parte-se da provocação de que, na cultura contemporânea, o corpo está sendo destruído pela imagem. A imagem é o grande outro do corpo, os corpos aspiram ser imagem (BAITELLO Jr, 2014a).

Ainda é majoritário o paradigma que, no estudo da imagem, valoriza quem fala; o impacto é menosprezado, a imagem é objeto. Realizam-se assim entendimentos de um emissor autoritário e um receptor que tem um produto como fetiche.

A imagem não é um objeto, é um sujeito, olha de volta, é criadora, gera um ambiente. Uma imagem feita para culto cria ambiente de culto, imagem feita para arte cria ambiente de arte. Para percebermos isso, basta pensarmos a mesma imagem em uma igreja barroca, em um centro de arte contemporânea ou em uma praça.

A imagem é a presença viva de toda uma genealogia, de todas as imagens anteriores que geraram os esquemas que a tornam possível hoje. Assim, em um anúncio publicitário, temos tradição histórica na constituição de padrões e símbolos que é revivida e atualizada. Esquecer isso é achar, a todo momento, que estamos inventando a roda. Nossos alunos talvez não o saibam, sentem-se poderosos com suas criações e expressões em aparelhos tecnológicos. ${ }^{7}$

Não é possível catalogar as imagens, mas é possível identificar os ambientes por elas gerados: ambientes de culto, de arte, de mídia. A imagem mítica era imanente, tratava de algo essencial. A imagem de culto transportanos para outro lugar, é transcendente. A imagem de arte volta a ser imanente, embevece. A imagem de mídia leva-nos a fazer coisas, persuade, tira-nos do corpo, transcende (BAITELLO Jr, 2014a). Um ambiente não exclui o outro, incorpora-o. Assim, o ambiente de mídia traz em si mito, culto e arte.

A imagem midiática quer nos levar para um lugar ou atitude em que não estamos, quer nos levar ao desaparecimento, consumir, do latim sumire, sumir. As pessoas são visíveis pelo que consomem, são visíveis por sumir! Ou por morrerem como pessoas. Baitello Jr fala de iconofagia, as imagens querem devorar nossos corpos. A televisão sabe porque nos quer deitados no sofá. Ser é parecer, ser imaginado.

Mídia, do latim medium, meio, é espaço intermediário, meio de campo, aquilo que fica entre uma coisa e outra. A primeira mídia é o corpo,

7 Para encaminhar a reflexão de que as relações entre mídias, cultura e tecnologia não são novas, ler "A história da comunicação e os desafios educacionais em época de internet" (SILVA, 2014). Disponível em: <http://www.fecilcam.br/educacaoelinguagens/documentos/v3n5/5o-61.pdf>. 
complexo, presencial, exige tempo e espaço. As linguagens do corpo são o ponto de partida e chegada da comunicação. O corpo é o primeiro suporte dos textos culturais. As imagens, quando exiladas do corpo, são tiranas, não nos refletem, mas sim nos inventam. Assim como Jenkins, Baitello Jr entende que comunicação e cultura são indissociáveis.

Ocorre uma coerção para transformar pessoas complexas, corpos vivos em imagens, em uma forma estratégica de conquista.

Estaremos caminhando para uma sociedade que, por banir os traços e as marcas do tempo, por banir o envelhecimento, a lentidão, por desvalorizar e por fim também banir a proximidade, oferece às crianças, jovens e adolescentes um horizonte obscurecido pelas excessivas luzes dos holofotes de um falso presente, um presente in effigie, sem corporeidade, sem presença, um presente vivo e sem surpresas (BAITELLO Jr, 2014b, p. 42).

Quando usamos um objeto para transmitir sinais, criando uma presença na ausência, usamos uma mídia secundária. É o que ocorre com a escrita, decodificação, decifração, com seu tempo lento e de contemplação. Quando se tem o tempo de ler um livro, ler um romance, olhar um quadro, mergulhar numa imagem e contemplá-la, entra-se na realidade regida por uma temporalidade distinta, aquela da permanência, da perenidade, da imortalidade. ${ }^{8}$

Quando é necessário um aparato de transmissão e um aparato de recepção, transmitem-se sinais sem suporte, o tempo acelera-se vertiginosamente. É a mídia terciária, como o telégrafo, telefone, rádio, televisão. Com a aceleração do tempo, estamos a perder o espaço comunicativo do diálogo interpessoal. Atualmente, vivemos o excesso e descontrole das imagens, sua inflação gera fadiga do olhar e invisibilidade! Temos tantas imagens à disposição que nos tornamos cegos. O olhar é o sentido do alerta e da distância, vivemos essa agonia.

É importante lembrar que o processo educacional é um processo de por para sentar, no sentido de por para se acalmar. Como pensar sem interiorizar? Como conhecer sem autoconhecer? Não estamos desequilibrados, excessivamente voltados para fora, para a transcendência das luzes e da

8 Para reflexões sobre as relações entre imagem e morte, no campo da fotografia, ler "Click... ou bang: imagens da morte na historiografia sobre fotografia" (SILVA; ANDRÉ, 2012). Disponível em: <http://www.uel.br/revistas/dominiosdaimagem/index.php/dominios/article/view/150>. 
aparência? Porém, podemos extrair o que queremos e deixar a manipulação. Podemos ensinar a resistir às imagens midiáticas, denunciar o excesso que gera adormecimento nos olhos. Para quem pensa comunicação e cultura, o desafio é resgatar o sentido, recuperar o homem e seus vínculos, o que apenas é possível integrando áreas de saber, exercendo nossa capacidade crítica em favor dos potenciais humanos.

Temos a necessidade de vincular o espaço e o tempo. E a mídia a partir da qual cada um se apropria de seu espaço e seu tempo é o corpo. A comunicação é construção de vínculos, por meio dos processos comunicacionais, portanto, podemos refletir sobre nossos vínculos; por meio do uso das diferentes mídias em sala de aula, o corpo inclusive, podemos pensar em nossos processos de aprendizagem, em como e se satisfazemos nossas necessidades.

Em vez de consciência do corpo, vivemos a imagem do corpo. $\mathrm{O}$ excesso de imagens, o excesso de telas, o excesso de luz, deixa-nos carentes da consciência da sombra, do recolhimento. A sombra está lá, torna-se maior e assustadora, mas preferimos um lado apenas da equação, a luz, vivendo assim o desconforto da não interioridade, de não ter recolhimento. No intervalo, olhamos as mensagens, e não para dentro de nós mesmos.

$\mathrm{O}$ medo da morte produziu imagens, o medo das imagens produziu sua aceleração, ritmo que não nos remete mais às coisas, mas às próprias imagens. O outro indesejável é o interior, é o que está dentro de nós mesmos, em um mundo que apela à transcendência do visível. É bastante curioso que vivemos, sem dúvida, ideologias dos corpos belos, porém, não vivemos os corpos.

As máquinas que falam e transmitem falas e imagens expandem as fronteiras da percepção, gerando encantamento, magia. Esse fenômeno não é novo. "A magia não tem e nunca teve como meta informar, mas sim encantar, iludir, desviar a atenção, literalmente enganar” (BAITELLO Jr, 2014b, p. 101).

Para o autor, os sistemas de visão e entendimento, ou seja, as mídias, têm fracassado em sua missão de conectores, pois sucumbem ao mal da autorreferência. Em rede, mantemos o processo, fazemos referência à própria mídia, perdendo a posição de mediação, de meio. Trata-se de imagens desenraizadas, que perderam os vínculos de origem, parecendo autossuficientes.

Baitello Jr defende a conquista da lentidão. O tempo da escrita, por exemplo, é tempo lento, que permite reflexão, decifrar enigmas, alongando a percepção do tempo de vida.

Assim, a representação de um objeto não é apenas a representação de algo existente no mundo (concreto, das coisas, ou não concreto, das não coisas), mas também uma reapresentação das maneiras pelas quais 
este algo foi já representado. Em outras palavras, em toda imagem existe uma referência às imagens que a precederam. [...] A força de uma imagem provém de seu lastro de referências a outras tantas imagens [...] genomas imagéticos (BAITELLO Jr, 2014b, p. 128).

Estamos acelerados, e isso tornou-se valor positivo. A visão está saturada de luzes e telas, produzimos um "recalque ao crepuscular". Hoje, tornamo-nos imagens antes de tornarmo-nos pessoas. A visibilidade que constitui nossos avatares tem uma temporalidade encurtada quando comparada à temporalidade da audição. Vemos muito, escutamos pouco.

A escuta requer uma postura receptiva, passiva. A recepção da imagem requer ação. São dois universos: passivo, de paixão, associado a sentimento; e ativo, associado a agir, fazer, dois universos complementares que interagem. $\mathrm{O}$ ativismo, o trabalho como valor máximo, a produção em ritmo veloz tem uma história que vem de longe. $\mathrm{O}$ autor conclama a uma rebeldia civil contra o paradigma da produção. Estamos a perder as conexões do fluxo lento, da temporalidade do ouvir e do contemplar. Volto assim às questões problematizadas: o que ensinamos? Nossos objetivos são coerentes com nossos métodos? O que esperamos? Sabemos esperar?

Minha mãe, entre as décadas de 1940 e 1950, criança, escrevia cartas, solicitada por familiares e amigos analfabetos. Esses iletrados tinham histórias a contar e contavam. Histórias esperadas por semanas ou meses por pessoas queridas que estavam longe. O tempo da fala e da escuta, da tradução da escrita, do transporte, da leitura e releitura da carta, preciosamente guardada em lugar seguro. Este tempo, em poucas décadas, foi substituído por uma foto de celular e a alocação em um arquivo que muitas vezes não será mais visto ou encontrado. Não temos tempo de ouvir, tampouco olhos de ver... 


\section{Referências}

ANDRÉ, R. G.; SILVA, A. C. T. Click... ou bang? Imagens da morte na historiografia sobre fotografia. Revista Domínios da Imagem, ano V, n. 10, maio 2012. p. 31-41. Disponível em: <http://www.uel.br/revistas/dominiosdaimagem/index.php/ dominios/article/viewFile/150/107>.

ARENDT, H. A crise na educação. Entre o passado e o futuro. Tradução: Mauro W. Barbosa de Almeida. 3. ed. São Paulo: Perspectiva, 1992.

BAITELLO Jr, N. As imagens e seus ambientes. Conferência proferida no I Encontro Nacional de Pesquisa em Comunicação e Imagem. Universidade Estadual de Londrina (UEL), 25 nov 2014 a.

BAITELLO Jr, N. A era da iconofagia: reflexões sobre a imagem, comunicação, mídia e cultura. São Paulo: Paulus, 2014b.

JENKINS, H. Cultura da convergência. Tradução de Susana Alexandria. 2 ed. São Paulo: Aleph, 2009.

McLUHAN, M. Aula sem paredes. In: CARPENTER, E.; McLUHAN, M. (orgs.) Revolução na comunicação. Tradução de: Álvaro Cabral. Rio de Janeiro: Zahar, 1968. [original $=1960$ ]

SANTAELLA, L. Navegar no ciberespaço: o perfil cognitivo do leitor imersivo. São Paulo: Paulus, 2004.

SILVA, A. C. T. A história da comunicação e os desafios educacionais em época de internet. Revista Educação e Linguagens, v. 3, n. 5, p. 50-61, 2014. Disponível em: <http://www.fecilcam.br/educacaoelinguagens/documentos/v3n5/50-61.pdf>. 


\title{
Comunicação, Educação e Cultura: possíveis inter-relações no contexto da sociedade midiatizada ${ }^{1}$
}

\author{
Camila de Alvarenga Assis e Silva \\ Pontifícia Universidade Católica de Minas Gerais
}

\section{Introdução}

No cenário sociocultural contemporâneo, caracterizado pela sociedade midiatizada e por profundas transformações proporcionadas pelas Tecnologias da Informação e da Comunicação (TICs), muitos são os debates que evidenciam como os avanços nestas áreas facilitam a troca de conhecimentos, permitem a conexão entre os indivíduos, potencializam os intercâmbios culturais e dinamizam processos de aprendizagem, como, por exemplo, o Ensino à Distância (EAD).

Para muitas instituições, como a escola, a Comunicação ainda é vislumbrada somente pela perspectiva técnica dos meios e não como uma possibilidade de olhar o mundo de maneira crítica, de forma a incentivar o empoderamento do interlocutor e reforçar o seu sentimento de pertencimento, tornando-o parte do processo de significação ao mesmo tempo em que o torna capaz de se apropriar e utilizar das técnicas e dos procedimentos inerentes ao fazer comunicacional, todos influenciados por aspectos internos e externos à indústria da informação. É neste contexto que, para Margarida Kunsch (1986, p. 6),

o debate dos caminhos cruzados entre a comunicação e a educação é um imperativo diante de uma realidade que, transformando-se rápida e profundamente, obriga o educador, não só a acompanhar de perto os passos da implantação das tecnologias da comunicação dentro da escola, mas também a entendê-la em toda sua dimensão política, econômica e social.

1 Trabalho originalmente apresentado no GP Comunicação e Educação, Congresso INTERCOM, Rio de Janeiro, 2015. Texto atualizado para esta publicação. 
Como pode ser observado em Kunsch (1986), a Comunicação e a Educação possuem interseções ainda pouco exploradas e, de certa forma, negligenciadas por parte das instituições, inclusive dos governos. São escassas as iniciativas que promovem políticas públicas de incentivo a um olhar crítico sobre o ambiente midiático (media literacy) ${ }^{2}$, principalmente entre crianças e jovens em relação aos meios aos quais têm acesso e com os quais se relacionam.

O exercício do olhar crítico e a atenção às peculiaridades que envolvem o processo de produção da informação se tornam extremamente importantes para que o sujeito se posicione no mundo de forma consciente, diante de um contexto fortemente marcado pela revolução tecnológica e pela hiper circulação de informações. Nesta perspectiva, vale ressaltar que as aplicabilidades interacionais dos meios de comunicação junto a processos educativos não devem ser pensadas somente pelo viés da regularização de conteúdos - nos veículos midiáticos - que não sejam considerados educativos, principalmente para crianças e adolescentes, ou somente pelo viés da educação para a mídia.

Como bem ressaltam Siqueira e Canela (2012, p. 15), proteger o público de conteúdos inapropriados e promover a formação de leitores e produtores críticos e autônomos não é o suficiente:

a regulação da mídia não se dá somente a partir de que os conteúdos audiovisuais apresentem riscos ao desenvolvimento da população infanto-juvenil. Em outras palavras, é preciso também atentar aos benefícios auferidos da interação com a mídia.

Assim, com a intenção de levantar hipóteses sobre as possíveis inter -relações entre os campos da Comunicação, da Educação e da Cultura no contexto da sociedade midiatizada, tomou-se como passo inicial a realização de uma revisão bibliográfica preliminar baseada em referenciais teóricos pertencentes tanto ao campo da Comunicação Social quanto ao da Educação e da Cultura.

No primeiro momento, busca-se tratar sobre como as visões transmissionistas da Comunicação e da Educação reduzem a participação do sujeito nos processos comunicacionais e de aprendizagem, ao ponto de vista da

2 Termo compreendido pela perspectiva da competência midiática, que, de acordo com Sá Martino e Menezes (2012, p. 12), seria "uma competência para ação e reflexão no ambiente midiático - no caso, midiatizado - a partir da construção de relações com seu modo de ser específico". 
recepção, polarizando a interação sujeito-objeto. Em um segundo momento, objetiva-se a problematização da midiatização da sociedade a fim de se pensar como este contexto possivelmente promove uma superação da visão polarizada entre sujeito e objeto ao considerar a interação entre eles.

Já no terceiro momento, são trabalhados os conceitos de "ecossistema comunicativo" e "condição comunicacional contemporânea" para indicarmos um apontamento rumo a um desdobramento conceitual destas interfaces entre Comunicação, Educação e Cultura na sociedade midiatizada. Nesta proposta, os vínculos entre Comunicação e Educação são compreendidos por um plano epistemológico no qual a relação entre estes campos se dá nas atividades dialógicas e dinâmicas entre sujeitos que interagem em um mundo de significados.

Este plano epistemológico também reflete sobre as novas redes de saberes diversos, experiências plurais dos sujeitos e suas formas de estarem no mundo decorrentes da interseção entre os processos comunicacionais, socioculturais e educativos, que enfrentam o desafio das TICs e das intercorrências da cultura midiática. Neste contexto, a Cultura será abordada como o pano de fundo onde ocorrem estas relações e que, ao mesmo tempo, passa por constantes mudanças decorrentes destas mesmas intercorrências.

\section{I - Comunicação, Educação e Cultura: a visão polarizada das instituições tradicionalistas}

Segundo Kenski (2008, p. 650), “a relação biunívoca em que se entrelaçam educação e comunicação engloba os mais diferenciados assuntos, concepções e linhas teóricas, práticas, sujeitos, tempos e processos formais e não-formais, conscientes e determinados, ou nem tanto assim”. Entretanto, no âmbito destes debates, observa-se que grande parte da discussão se refere à relação polarizada entre os sujeitos e seus objetos.

Boa parte dos debates epistemológicos sobre o estatuto da comunicação e da educação ocorrem em torno da discussão sobre a relação entre os sujeitos e seus objetos. As abordagens tradicionais em ambos os campos, trabalham com paradigmas que tomam de empréstimo perspectivas comportamentalistas de fundo funcionalista-pragmático, empiricista e matemático, que submetem tanto o processo de educação, quanto o de comunicação à ideia transmissionista. (ALVARENGA et al., 2014, p. 70). 
Neste contexto, as abordagens que tratam o processo da Comunicação e o da Educação de forma pragmática e transmissionista consideram que os sujeitos são de um lado emissores/educadores e de outro receptores/ educandos, sendo que entre os primeiros e os segundos existem os ruídos, que representam tudo que possa interferir no processo de codificação e decodificação/aprendizado por parte dos receptores/educandos.

De acordo com esta perspectiva, "comunicar e educar seria produzir um movimento de transferência de um polo a outro" (BRAGA, 2006, p. 157). Neste caso, os processos de Comunicação e Educação são considerados resultados de uma recepção passiva, advinda da imposição de um polo (emissor/educador) sobre outro (receptor/educando).

Apesar de criticada e desconstruída pela perspectiva interacionista e pela vertente dos estudos culturais, especialmente, a obra de Martín -Barbero, Dos meios às mediações, publicada em 1987, esta perspectiva funcional, pragmática e empiricista, continua viva e ainda atuante na gestão de processos educativos e comunicacionais, especialmente, nos ambientes institucionais (ALVARENGA et al., 2014, p. 3).

Neste caso, os sujeitos são postos como meros receptores e considerados ativos somente quando respondem a um estímulo. Desconsiderase completamente o contexto no qual eles estão inseridos no momento em que ocorre o processo comunicativo ou educativo, fator já considerado por Martín-Barbero desde 1980, quando sinalizou em Dos meios às mediações a importância da inserção cultural do receptor como mediação fundamental entre a sociedade e a mídia de massa.

Em relação às fronteiras de interface da Comunicação com a Educação, Melo e Tosta (2008, p. 11) consideram a mídia como um sistema constituído pelos meios de comunicação "que funcionam em convergência histórica com a rede educativa, particularmente a escola, onde se concretiza a formação dos cidadãos". Com o avanço das TICs, esta convergência é reforçada e apresenta, cada vez mais, incontáveis possibilidades de interseção entre estes campos. A tecnologia, a internet e as redes sociais ampliam as capacidades educativas e ultrapassam os muros da escola, afetando o cenário da Cultura e, também, sendo afetado pelos circuitos culturais. Na maioria das vezes, as TICs tornam-se as mediadoras das interações. "Hoje em dia, a tecnologia já não é pontual, ela nos atravessa de ponta a ponta tanto espacial como temporalmente" (MARTÍN -BARBERO, 2014, p. 128). 
Por outro lado, Martín-Barbero (2014) aponta que, principalmente na América Latina, a visão desta interação por parte dos governos é a de que a Cultura não está diretamente relacionada com o desenvolvimento tecnológico dos meios, tampouco a Educação. De acordo com ele,

os feudos políticos continuam mantendo separadas as políticas nos âmbitos da cultura e da comunicação com relação ao da educação, e nessa ausência de relações nossos países estão jogando fora sua própria visibilidade tanto social como produtiva, tanto política como cultural (MARTÍN-BARBERO, 2014, p. 54).

Uma vez que a importância da aproximação das políticas públicas nos âmbitos da Cultura, da Comunicação e da Educação ainda não é reconhecida, o desafio em questão pode estar na superação das visões tradicionalistas, tanto por parte dos educadores quanto dos profissionais de comunicação e das instituições que representam cada campo. Cabe a eles reforçarem este laço por meio do estabelecimento de novos olhares e da aplicabilidade de novas possibilidades que surgem a partir da interface entre os processos comunicacionais, educacionais e culturais, principalmente no contexto da sociedade midiatizada.

\section{II - Perspectivas interacionais entre os campos da Comu- nicação, Educação e Cultura sob a Ótica da Midiatização}

A articulação das tecnologias da informação e da comunicação com as instituições e com as novas configurações dos modos de o sujeito ser e estar no mundo acarreta em uma certa virtualização das relações, tanto entre os indivíduos quanto entre os sujeitos e seus objetos. Esta virtualização não acontece, necessariamente, por influência direta dos dispositivos tecnológicos nos indivíduos - como somente a propagação do uso de smartphones, da internet e das redes sociais por si só -, mas sim, esta virtualização se apresenta como uma influência do digital e das mídias na maneira como os seres humanos se relacionam entre si e, também, como os próprios indivíduos se apropriam das tecnologias.

Afinado a este pensamento, Sodré (2002, p. 21) considera que a midiatização:

é uma ordem de mediações socialmente realizadas no sentido da comunicação entendida como processo informacional, a reboque de 
organizações empresarias e com ênfase num tipo particular de interação - a que poderíamos chamar de "tecnointeração" -, caracterizada por uma espécie de prótese tecnológica e mercadológica da realidade sensível, denominada "médium".

De acordo com Sodré (2002), vivenciamos um bios midiático3. Tese segundo a qual os dispositivos sociotécnicos instauram uma ordem social do vivido que se caracteriza por um processo hipertrofiado de virtualizações. $\mathrm{O}$ autor acredita que, na atualidade, o relacionamento do sujeito com a realidade passa necessariamente pela tecnologia, em especial as tecnologias da informação em todos os seus modos de realização. "A forma da consciência contemporânea é fundamentalmente tecnológica” (SODRÉ, 2012, p. 13).

Se, por um lado, as abordagens tradicionais da Comunicação e da Educação submetem os processos comunicacionais e educativos a uma ideia transmissionista, relegando a participação do sujeito somente enquanto receptor ou educando, por outro lado, observa-se que, no contexto da sociedade midiatizada, esta visão se torna ultrapassada e desarticulada com os processos interacionais e a configuração das produções simbólicas cotidianas.

Na sociedade em midiatização, a interação se manifesta mais claramente como um fluxo sempre adiante. Com a emissão de uma mensagem, seja televisual, cinematográfica ou por processos informatizados em rede social, o "receptor", após apropriação de seu sentido (o que implica a incidência das mediações acionadas), pode sempre repor no espaço social suas interpretações. Isso ocorrerá seja em presencialidade (em conversações, justamente), seja por outras inserções midiatizadas - cartas, redes sociais, vídeos, novas produções empresariais, blogs, observatórios, etc. Os circuitos aí acionados - muito mais abrangentes, difusos, diferidos e complexos - é que constituem o espaço das respostas "adiante" na interação social (BRAGA, 2011, p. 68).

Grande parte de nossa subjetividade e produção simbólica é permeada por esta articulação e convergência entre as tradicionais estruturas de

3 Muniz Sodré defende a hipótese de que os meios de comunicação contemporâneos estão criando outra esfera existencial, o que o filósofo Aristóteles chamava de bios. De acordo com ele, existiam três esferas na pólis grega; a esfera da política, do conhecimento e dos prazeres. Baseado em Aristóteles, Sodré imagina um quarto bios feito de informação, de virtualidade. A esta quarta esfera, ele dá o nome de bios virtual ou bios midiático. 
comunicação de massa e a internet. O processo de midiatização, construído no fluxo da vida cotidiana entre os meios de comunicação e nos processos de subjetivação, reconfiguram nossos modos de ser e nossa vida coletiva (JESUS, 2013). Esta reconfiguração da vida coletiva e dos modos de ser e estar no mundo proporcionados pelas afetações do processo de midiatização, que por sua vez também são afetados pelas mudanças socioculturais, realocam produtores e receptores, bem como educadores e educandos.

De acordo com Fausto Neto (2008, p. 93), no período da sociedade dos meios - aproximadamente até o fim do século XX — , as mídias "teriam uma autonomia relativa face à existência dos demais campos". A sociedade sofria os efeitos dos meios de comunicação de massa sem poder controlá-los. Por sua vez, na sociedade midiatizada, "a cultura midiática se converte na referência sobre a qual a estrutura sócio-técnica-discursiva se estabelece, produzindo zonas de afetação em vários níveis da organização e da dinâmica da própria sociedade" (FAUSTO NETO, 2008, p. 93).

Os sujeitos se relacionam e convivem em um circuito comunicacional no qual têm acesso a diferenciados estímulos de informação, mensagens e conteúdos (quer seja audiovisual, sonoro ou textual) e podem, a partir de suas apropriações de sentido, compartilhar socialmente suas interpretações, também por meios diferenciados (imagem, texto e som), de forma interativa e, até mesmo, gratuita.

É no cenário da sociedade midiatizada, dos novos paradigmas sociotécnicos, da ambiência midiática, da presença dos nativos digitais ${ }^{4}$, de formas de sensibilidade e sociabilidade orientadas por outras percepções dos vínculos entre tempo e espaço, que podemos refletir sobre as formas atuais das configurações inter-relacionais entre a Comunicação, a Educação e a Cultura (CITELLI, 2010). Nesta perspectiva, devemos pensar a Comunicação não como o sinônimo de mídia ou dos meios de comunicação pura e simplesmente, mas como um campo que assume um importante papel na configuração das mediações, das interações socioculturais e na organização da sociedade. Afinal, de acordo com Sonia Livingstone (2009), citada por

4 Em seu artigo “Comunicação e educação: implicações contemporâneas”, Adilson Citelli explica que esta expressão é utilizada por Marc Prensky para designar aqueles que nasceram sob o signo da revolução informacional, telemática, sendo por ela embalados. Ao contrário, os migrantes digitais, herdeiros da sociedade industrial, têm que se adaptar aos novos paradigmas sociotécnicos. PRENSKY, Marc. Don't bother me, mom. I'm learning. (Não me aborreça, mãe. Estou estudando). St. Paul: Minnesota: Paragon House, 2006. 
Andreas Hepp (2014, p. 53), "nossa vida atual é marcada pela "mediação de tudo’ que age em diferentes mídias ao mesmo tempo".

Tampouco a Educação pode ser remetida ao território institucional formal e da fala unidirecional do professor em sala de aula, mas sim considerada como um campo aberto ao diálogo, às interações e às trocas midiatizadas. Ela já não pode mais ser concebida a partir de um modelo de comunicação escolar que não acompanhe, espacial e temporalmente, os processos de formação advindos da era da informação, uma vez que, segundo Martín -Barbero (2014, p. 121), "estamos passando de uma sociedade com sistema educativo a uma sociedade do conhecimento e aprendizagem contínua, isto é, sociedade cuja dimensão educativa atravessa tudo: o trabalho e o lazer, o escritório e a casa, a saúde e a velhice”. Aprende-se em qualquer lugar e de diversas formas, não somente no espaço institucional da escola.

Para Paulo Freire (1985, p. 46), “a educação é comunicação, é diálogo, na medida em que não é transferência de saber, mas um encontro de sujeitos interlocutores que buscam a significação do significado". Dessa forma, o encontro da Comunicação, da Educação e da Cultura pode acontecer por meio de andamentos dialógicos (CITELLI, 2010) que desencadeiem relações intersubjetivas e formas de coenunciação em detrimento da recepção - termo concebido nas teorias informacionais - e propõem a ideia de que a comunicação se torna completa quando os campos de sentidos colocados em circulação social são apreendidos, tornando possível a constituição de fluxos de mensagens, sempre adiante, pelos agentes implicados neste processo comunicacional.

A fim de melhor compreender os meandros desta totalidade de circuitos de retroalimentação que envolvem desde o plano da produção material até os jogos enunciativos, passando pelas estratégias de composição e circulação das mensagens, no próximo tópico, serão tratados os termos ecossistema comunicativo e condição comunicacional contemporânea para, também, investigarmos um possível apontamento rumo a um desdobramento conceitual destas inter -relações entre Comunicação, Educação e Cultura na sociedade midiatizada.

\section{III - Ecossistema Comunicativo e Condição Comunicacio- nal Contemporânea: possíveis desdobramentos conceituais}

A interação entre sujeito e objeto nos processos de comunicação e educação, proposta como forma de superar uma visão polarizada e 
transmissionista, dá-se no âmbito do dialogicidade, da mediação, da troca e da valoriozação da diversidade cultural. O sujeito não recebe passivamente os estímulos do emissor, e sim os ressignifica de acordo com sua vivência, repertório e subjetividade, colocando novamente em circulação social a mensagem reinterpretada.

A textura dialógica se encontra tanto na textura do símbolo como na constituição da subjetividade: o eu só se torna real na reciprocidade da Interlocução. Dialogar é arriscar uma palavra ao encontro não de uma ressonância, de um eco de si mesma, mas sim de outra palavra, da resposta de um outro (MARTÍN-BARBERO, 2014, p. 33).

Dessa forma, o processo de produção e circulação de sentidos se faz por meio da linguagem, que é mais do que uma forma de expressar ideias e veicular discursos e narrativas. A linguagem é "uma forma de habitar o mundo, de se fazer presente nele, de compartilhá-lo com outros homens" (MARTÍN-BARBERO, 2014, p. 37).

É por isto que a Comunicação e a Educação não devem ser pensadas somente considerando os meios como dimensões a elas exteriores e acessórias, nem pensá-las como acionadas exclusivamente pelos meios. O desafio é concebê-las como um dos lugares da construção dos sentidos sociais. "Para além dos meios, mas não sem eles" (BACCEGA, 2008, p. 3).

Nesta perspectiva, um enquadramento conceitual que se refere ao reconhecimento da singularidade e complexidade da comunicação - por meio dos conceitos de "ecossistema comunicativo" (MARTÍN-BARBERO, 2000; 2014) e "condição comunicacional contemporânea" (OROZCO, 2014) - pode mostrar-se central para reverter a visão reducionista em relação à Comunicação e a Educação, além de proporcionar uma análise da relação entre elas.

Martín-Barbero, em concordância com Pierre Lévy (2004, p. 83), em sua obra As Tecnologias da Inteligência: o futuro do pensamento na era da informática - em que o autor afirma que "o pensamento se dá em uma rede na qual neurônios, módulos cognitivos, humanos, instituições de ensino, línguas, sistema de escrita e computadores se interconectam, transformam e traduzem representações" -, faz referência, tanto em sua obra A comunicação na educação (2014) quanto no artigo Desafios Culturais da Comunicação à Educação (2000), a um termo essencial para a análise da relação entre Comunicação, Educação e Cultura: o "ecossistema comunicativo". De acordo com ele,

a primeira manifestação e materialização do ecossistema comunicativo é a relação com as novas tecnologias - desde o cartão que substitui 
ou dá acesso ao dinheiro, até as grandes avenidas da Internet - com sensibilidades novas, muito mais claramente visíveis entre os jovens. [...] Uma segunda dinâmica, que faz parte desse novo ecossistema no qual vivemos, e que é a dinâmica da comunicação, liga-se ao âmbito dos grandes meios, ultrapassando-os, porém. Ela se concretiza com o surgimento de um ambiente educacional difuso e descentrado, no qual estamos imersos. Um ambiente de informação e de conhecimento múltiplos, não-centrado em relação ao sistema educativo que ainda nos rege e que tem muito claros seus dois centros: a escola e o livro (MARTÍN-BARBERO, 2000, p. 54).

Nesta perspectiva, o livro é importante sim, mas para uma primeira alfabetização, aquela que fomenta a escrita. Contudo, ela deve ser acompanhada por uma segunda alfabetização, "relacionada às múltiplas escrituras que o audiovisual e o texto eletrônico permitem. Não se trata de pensar a substituição de uma coisa pela outra, mas a complexa articulação e imbricamento de uma coisa na outra" (ALVARENGA et al., 2014, p. 4).

É neste contexto que o ecossistema comunicativo compreende toda a complexidade das redes e saberes cada vez mais mediados por dispositivos tecnológicos e pela expressão da diversidade cultural (ALVARENGA et al., 2014), que também deve ser levada em conta de acordo com a abordagem de Barros (apud BARROS et al., 2011, p. 19):

Por resultar das trocas entre sujeitos, grupos sociais e instituições, que por sua vez são opostos, divergentes e contraditórios, a Diversidade Cultural, promove, a partir de suas diferenças, tanto a multiplicidade cultural e intersubjetiva, como também, a partir de suas desigualdades, tensões e conflitos.

O ecossistema comunicativo é dinâmico e marca a vida nas sociedades contemporâneas, em especial a dos jovens. Ele é constituído por novos meios, linguagens e padrões de escrita, além da hegemonia da experiência audiovisual e a integração da imagem no campo da produção de conhecimentos (ALVARENGA et al., 2014). Por sua vez, o conceito de condição comunicacional contemporânea é expresso por Orozco (2014) para designar o processo em que o comunicativo assume lugar central na organização da sociedade, das interações socioculturais e das mediações.

É essa condição comunicacional que permite aos participantes dos processos comunicativos mediados por telas, desconstruir, de maneira real ou material, e não somente reinterpretar, ressignificar ou desconstruir simbolicamente, como de fato sempre foi possível, os objetos de seu intercâmbio comunicativo (OROZCO, 2014, p. 31). 
Dessa forma, para o autor, sempre foi possível a reinterpretação ou desconstrução simbólica dos objetos de intercâmbio comunicativo por parte dos participantes dos processos comunicativos. Entretanto, agora, esta condição comunicacional é mediada por telas e permite a estes participantes uma desconstrução de maneira real ou material.

A configuração do ecossistema comunicativo contemporâneo, para Orozco (2014), é marcada por duas mudanças centrais: 1) o trânsito da condição de receptor/audiência para a condição de usuário/prossumidor (produtor + consumidor) - conceito próximo de coenunciador/coenunciação, abordado no tópico anterior; e 2) o processo de migração do analógico para o digital. Tais mudanças, nessas formas de produção e circulação de conhecimento, segundo Martín-Barbero (2014), são as transformações mais radicais que uma sociedade pode viver.

O descentramento do conhecimento, que faz com que ele circule por outros meios que não apenas os livros altera a nossa forma de ler a realidade; a deslocalização permite que o conhecimento possa se dar em vários outros espaços e em outras temporalidades que não apenas no espaço/tempo escolar (ALVARENGA et al., 2014, p. 5).

Assim, por meio desses conceitos, é possível relacionar as mudanças da mídia e da comunicação, por um lado, e as mudanças socioculturais e educacionais, por outro, de forma a compreender melhor como as configurações comunicativas da sociedade midiatizada interferem nos processos inter-relacionais da Comunicação, da troca de conhecimentos, do intercâmbio cultural e, também, como estes mesmos processos interferem nas próprias configurações comunicativas da sociedade midiatizada e fomentam as mudanças midiáticas, comunicativas, socioculturais e educativas.

\section{IV - Considerações Finais}

A forma como os processos comunicacionais e educativos são vistos e considerados pelas instituições afeta diretamente o ambiente sociocultural contemporâneo. A maneira como se constitui a sociedade, cada vez mais relacionada com os meios de comunicação, realoca o sujeito a uma posição de coenunciador dos processos comunicativos. Esta constituição da sociedade midiatizada evidencia as potencialidades interacionais dos sujeitos com seus objetos, diversifica as mediações, amplia o campo de produção simbólica e os 
formatos de aprendizagem, promovendo mais possibilidades de ressignificação e compartilhamento de conteúdos com outros sujeitos, por diversos meios, de maneira a formar uma rede de saberes diversos e experiências plurais.

Tudo que está associado a isto, e não somente os meios por onde isto acontece, é Comunicação. São, também, processos educativos e constituem a diversidade cultural. $\mathrm{O}$ que pode reforçar, ainda mais, os laços inter-relacionais entre a Comunicação, a Educação e a Cultura. Os conceitos de ecossistema comunicativo e condição comunicacional contemporânea abarcam muitos aspectos do que é vivenciado pelos diversos atores dos processos de Comunicação e Educação - novas sensibilidades, formas de sociabilidade, produção de sentidos e escritas.

Entretanto, se, por um lado, os sujeitos das interações comunicacionais têm acesso a uma maior quantidade de informações, aprendem por diversas plataformas, em diferentes espaços e o tempo todo; por outro, ainda são considerados meros receptores por grande parte das instituições que ainda consideram a relação sujeito-objeto de forma polarizada em detrimento de uma visão interacional. Basta ter acesso aos Planos Nacionais de Educação do Brasil para notar como a questão da Comunicação está reduzida aos seus aspectos instrumentais e acessórios à Educação, mesmo diante de uma realidade sociocultural contemporânea que vai contra esta perspectiva. Como apontado no texto, é preciso superar esta visão tradicionalista e polarizada dos processos comunicativos e educativos de forma a reconhecer, fomentar e valorizar o protagonismo do sujeito nestes processos levando em conta o contexto sociocultural no qual ele se insere. E não somente impor como regra uma configuração já estabelecida destes processos, todavia ultrapassada. 


\section{Referências}

ALVARENGA, C. et al. A comunicação no Plano Nacional de Educação do Brasil: uma aproximação crítica. Cuadernos.info, Chile, vol. 35, p. 69-81, dezembro 2014. Disponível em: <http://cuadernos.uc.cl/uc/index.php/CDI/article/view/ cdi.35.651/pdf $>$.

BACCEGA, M. A. Campo Comunicação/Educação: mediador do processo de recepção. NP Comunicação Educativa, VIII Encontro dos Núcleos de Pesquisa do XXXI Intercom, 2008. Disponível em: <http:/www.intercom.org.br/papers/nacionais/2008/resumos/R3-0134-1.pdf>.

BARROS, D. L. P. de. Dialogismo, polifonia e enunciação. In: BARROS, D. L. P. de; FIORIN, J. L. (Orgs.). Dialogismo, polifonia, intertextualidade. 2. ed. São Paulo: EDUSP, 2003.p.1-9.

BARROS, J. M. et al. Relatório de Pesquisa: Mapeamento de Políticas para a Diversidade Cultural: Estudo de caso de Belo Horizonte, 2011. Disponível em $<$ http://observatoriodadiversidade.org.br/site/pesquisa/pesquisas/>.

BRAGA, J. L. A sociedade enfrenta sua mídia: dispositivos sociais de crítica midiática. São Paulo: Paulus, 2006.

Constituição do campo da comunicação. Revista Verso e Reverso 25 (58): 62-67, janeiro-abril 2011. São Leopoldo: Unisinos, 2011.

CITELLI, A. Comunicação e educação: implicações contemporâneas. Revista Comunicação \& Educação, Ano XV, n. 2, maio/ago 2010. Disponível em: <http://www.revistas.usp.br/comueduc/article/view/44821/48453>.

FAUSTO NETO, A. Fragmentos de uma analítica da midiatização. Matrizes, São Paulo, v. 1, n. 2, p. 89-105, abr. 2008. Disponível em: <http:/www.matrizes.usp.br/ index.php/matrizes/article/view/88/136>.

FREIRE, P. Educação e mudança. Tradução de Moacir Gadotti e Lílian Lopes Martin. Rio de Janeiro: Paz e Terra, 1983, v. 1.

Extensão ou comunicação. 8. ed. Rio de Janeiro: Paz e Terra, 1985. 
HEPP, A. As configurações comunicativas de mundos midiatizados: pesquisas da midiatização na era da "mediação de tudo". Matrizes. Revista do Programa de Pós-graduação da ECA-USP. São Paulo: ECA-USP. V.8. N $^{\circ}$ - jan/jul 2014. pp. 45-64. Disponível em: <www.revistas.usp.br/matrizes/article/download/82930/85964>.

JESUS, E. de. Em torno da comunicação e da arte na contemporaneidade. In: PESSOA, F. (org). Cyber - Arte - Cultura: a trama das redes. Rio de Janeiro: Suzy Muniz Produções, 2013. Disponível também em: <www.academia. edu/4147070/Em_torno_da_comunicacao_e_da_arte_na_contemporaneidade>.

KENSKI, V. M. Educação e Comunicação: interconexões e convergências. Educação \& Sociedade, Campinas, vol. 29, n. 104 - Especial p. 647-665, out. 2008.

KUNSCH, M. M. K. (Org.). Comunicação e educação: caminhos cruzados. São Paulo: Loyola, 1986.

LÉVY, P. As tecnologias da Inteligência - O futuro do pensamento na era da informática [Intelligence technologies - The future of thought in the informatic age]. São Paulo: Editora 34, 2004.

MARTÍN-BARBERO, J. Desafios Culturais da Comunicação à Educação. Revista Comunicação \& Educação, São Paulo, v. 6, n. 18, p. 51-61, maio/ago. 200o. Disponível em: <http:/www.revistas.univerciencia.org/index.php/comeduc/article/ view/4108/3860>

A comunicação na educação. São Paulo: Contexto, 2014.

MELO, J. M. de; TOSTA, S. P. Mídia e educação. Belo Horizonte: Autêntica, 2008.

OROZCO, G. G. Educomunicação - recepção midiática, aprendizagens e cidadania. Petrópolis: Paulinas, 2014.

SÁ MARTINO, L. M.; MENEZES, J. E. de O. Media Literacy: competências midiáticas para uma sociedade midiatizada. Líbero, São Paulo, v. 15, n. 29, p. 9-18, jun. de 2012. Disponível em: < http://casperlibero.edu.br/wp-content/uploads/2014/05/Texto-em-contexto-Media-Literacy.pdf $>$. 
SIQUEIRA, A. B. de; CANELA, G. Os porquês de uma política nacional de mídia- educação. Revista Comunicação \& Educação, São Paulo, v. 17, n. 2, p. 13 - 21 jul/dez, 2012.

SODRÉ, M. Antropológica do espelho: uma teoria da comunicação linear e em rede. Petrópolis: Vozes, 2002.

Reinventando a Educação: diversidade, descolonização e redes. 2.ed. Petrópolis, RJ: Vozes, 2012. 


\section{A mediação educomunicativa e o princípio da indissociabilidade entre ensino-pesquisa-extensão: da monocultura universitária à cultura plural ${ }^{1}$}

Concebemos aqui a universidade como um espaço de formação profissional, humanístico e intelectual do pensamento crítico, político e autônomo que enfrenta desafios e crises, principalmente no que se refere ao seu papel social, ao tipo de conhecimento produzido e ao perfil do profissional formado.

Souza Santos (2004) propõe que a Universidade reconquiste sua legitimidade, recuperando e ou reforçando sua responsabilidade social. Para tanto, precisa re/aprender a dialogar com os múltiplos saberes que integram a sociedade. Esse processo demanda maior atenção à extensão, à pesquisa -ação, à atuação em rede, a metodologias dialógicas, a procedimentos participativos de avaliação e a rever os mecanismos de democratização das ações e relações internas e externas. Dessa forma, poderá ocorrer, gradativamente, uma travessia do "conhecimento universitário para o conhecimento pluriversitário" (SOUZA SANTOS, 2004, p. 29). Trata-se de um conhecimento contextualizado, cuja produção se pauta na aplicação que é dado ao mesmo, ou seja, tem como princípio norteador a relevância social. Isso porque nem sempre a relevância acadêmica tem sido sinônimo de relevância social.

1 Trabalho originalmente apresentado no GP Comunicação e Educação, Congresso INTERCOM, Rio de Janeiro, 2015. Texto atualizado para esta publicação.

2 Doutora em Ciências da Informação e da Comunicação pela Universidade Federal do Rio Grande do Sul (UFRGS), Mestre em Ciências da Comunicação pela Universidade do Vale do Rio dos Sinos. Jornalista e Relações Públicas pela UNISINOS. Professora do Departamento de Ciências da Comunicação, do Programa de Pós-graduação em Comunicação e do Programa Tecnologias Educacionais em Rede da Universidade Federal de Santa Maria (UFSM). E-mail: rosanerosar@gmail.com. 
Diante desse cenário, objetivamos refletir, sem a pretensão de esgotar o estudo, sobre a contribuição da mediação educomunicativa na efetivação do principio da indissociabilidade entre ensino-pesquisa e extensão voltado à re/invenção de uma universidade mais democrática, emancipatória e com uma cultura plural. Um ambiente propício a trans/formação de sujeitos sensíveis às demandas socioculturais.

Para tanto, optamos pela pesquisa bibliográfica e pelo estudo de caso. As noções de Souza Santos (2004) sobre uma reforma democrática e emancipatória da Universidade; o conceito de cultura plural de Certeau (2008); os princípios educomunicativos de Freire (1999, 2000); Kaplún (1999); I. Soares (2010, 2011); Citelli (2011); D. Soares (2009); e as sociologias das ausências e as ecologias de saberes de Souza Santos (2007) fundamentam essa proposta inventiva e interventiva que segue uma perspectiva "marginal".

O capítulo está estruturado em três partes: iniciamos com a objetivação do princípio da indissociabilidade entre ensino-pesquisa-extensão na disciplina de Comunicação e Cidadania da Universidade Federal de Santa Maria (UFSM); na sequência, fazemos uma breve revisão conceitual sobre o campo da educomunicação e concluimos com a sociologia das ausências e as ecologias de saberes de Souza Santos, em diálogo com os relatos e significações de acadêmicos que integraram a proposta educomunicativa sinalizando travessias plurais.

\section{Objetivação e significação do princípio da indissociabili- dade entre ensino-pesquisa-extensão na Comunicação da UFSM}

Socializamos aqui nossa experiência democrática na Universidade Federal de Santa Maria (UFSM), onde exercitamos o princípio da indissociabilidade entre ensino-pesquisa-extensão no Departamento de Ciências da Comunicação. Ali coordenamos o Núcleo de Comunicação, Educação Intercultural e Cidadania, ministramos as disciplinas de Comunicação e Cidadania e Projeto Experimental de Produção Editorial para Educação (da graduação) e Mídia e Pluralismo (do Programa de Pós-Graduação em Comunicação POSCOM), Políticas Públicas e Tecnologias Educacionais em Rede (do Programa de Pós-Graduação em Tecnologias Educacionais em Rede-PPGTER). Apesar da riqueza vivenciada nessas disciplinas, optamos aqui, por questão de 
tempo/espaço, por refletir a respeito da experiência singular da disciplina de Comunicação e Cidadania (2015.1) para os acadêmicos dos Cursos de Comunicação com habilitação em Publicidade e Propaganda e Produção Editorial da UFSM. Uma mestranda e um doutorando em docência orientada também atuaram na disciplina. 3 A disciplina é de natureza teórico-prática. No bloco teórico (6oh), abordamos a origem e o desenvolvimento dos direitos humanos e de cidadania, direito a informação e a comunicação, a diversidade de formas de mobilização e participação da sociedade civil organizada, movimentos sociais voltados à democratização da comunicação, comunicação pública, comunicação comunitária, educomunicação e representações midiáticas das minorias. As leituras que fundamentam a abordagem dessas temáticas são inter/ transdisciplinares, ou seja: da área da comunicação, da sociologia política, da antropologia e da educação intercultural. As opções metodológicas incluem aula expositiva dialogada, seminários, estudo de casos e mesa redonda com a participação de representantes de movimentos sociais.

Já no bloco prático (zoh), há o planejamento, execução, avaliação e socialização de um projeto de intervenção voltado a uma temática social e a uma comunidade escolhidas pelas próprias equipes (Escolas Públicas, ONGs, Movimentos Sociais). A partir do conhecimento traduzido e debatido em aula, os acadêmicos tiveram a oportunidade de fazer a própria reconstrução mental e prática. As temáticas que despertaram maior interesse às equipes foram a educomunicação ambiental e de gênero. Para dar conta do desafio da indissociabilidade, demandou uma combinação metodológica e dialógica coerente com a epistemologia da educomunicação. Iniciamos com a pesquisa participante por se caracterizar em um processo de interlocução colaborativa que integra teoria e prática, demanda a inserção no ambiente pesquisado, participação dos sujeitos pesquisados, intervenção na realidade, protagonismo e autonomia, princípios éticos e cívicos e a socialização dos resultados (KEMIS; McTAGGART, 1988). Adotamos também a aprendizagem baseada em problemas, o estudo de caso e a produção colaborativa. No final do semestre, as equipes apresentaram os resultados à turma com um relatório no qual consta o projeto, a fundamentação teórica, detalhamento e documentação do processo, as produções, avaliações, significações e autoavaliações. Para esse momento, as equipes foram estimuladas a convidar

3 Cursos de Publicidade e Propaganda e Produção Editorial.

Ver mais em: http://w3.ufsm.br/educomufsm/ 
representantes da comunidade onde o projeto foi desenvolvido para assistir a apresentação. Posteriormente, muitos desses relatórios evoluíram para relatos de experiência ou artigos e foram apresentados em eventos científicos como o Educom Sul e o Educom Brasileiro. ${ }^{4} \mathrm{~A}$ postura adotada pelos professores-mediadores do processo de ensino-aprendizagem foi fundamentada na dialogisidade, no despertar da criticidade, da politicidade e da emancipação dos sujeitos envolvidos. Segundo Freire (2000, p. 81), cabe ao educador "problematizar aos educandos o conteúdo que os mediatiza”. Isso foi ocorrendo de forma gradativa ao longo do semestre, possibilitando a compreensão contextual das questões abordadas e das ações desenvolvidas.

Tanto na parte teórica quanto na parte prática, houve o exercício contínuo e dialético de estreitar a relação entre teoria e prática, razão e afeto, universidade e comunidade, conhecimento científico e saberes populares. Significa o esforço de renovar o processo de ensino-aprendizagem através de uma práxis de natureza política, pedagógica e comunicativa para possibilitar a insurgência de outras racionalidades e subjetividades. Portanto, a proposta da disciplina é contemporizar o direito humano e de cidadania a uma comunicação educativa, crítica e política, com potencial para promover maior igualdade entre as diferenças e mudar o paradigma da comunicação contemporânea por meio da experiência democrática e comunitária de outras formas de pensar e fazer comunicação.

No que se refere à justificativa para o uso do princípio da indissociabilidade entre ensino-pesquisa-extensão, apoiamos-nos no estudo de Moita e Andrade (2009), que recupera o pensamento de autores (SOUZA SANTOS, 2004; ESCOBAR, 2004; MIGNOLO, 2004; MORA-OSEJO; BORDA, 2004; MENESES, 2004; VISVANATHAN, 2004) que denunciam a pretensa superioridade colonial do conhecimento científico e identificam esse fenômeno como um tipo de "injustiça cognitiva” em caráter global que continua a colonizar no nível epistemológico as culturas e os saberes dos países periféricos.

Pensamos que o caminho para minimizar ou resolver essa “injustiça cognitiva” passa pela adoção do princípio da indissociabilidade no currículo do ensino superior. As três atividades (ensino-pesquisa-extensão) com as sua características singulares podem contribuir para re/inventar as relações entre universidade e sociedade, expandindo e democratizando o espaço para além dos sujeitos matriculados. Além disso, pode possibilitar a passagem da

411 equipes, uma média de cinco integrantes cada. 
construção de um conhecimento universitário para "pluriversitário" que, segundo Souza Santos (2004, p. 31), só é possível com “a inserção da universidade na sociedade e a inserção desta na universidade”.

No contexto brasileiro, o princípio da indissociabilidade está contemplado na Constituição de 1988, artigo 207: "as universidades [...] obedecerão ao princípio da indissociabilidade entre ensino, pesquisa e extensão". Porém, na prática, é comum nas Universidades Públicas a interação entre ensino e pesquisa, ficando de lado a intervenção social por meio da extensão. Essa exigência constitucional é retomada pela Política Nacional de Extensão e o Plano Nacional de Educação (2011-2020). Ambos preveem que o currículo dos cursos de graduação deve reservar uma cota mínima (10\%) do total de créditos exigidos para a atuação dos acadêmicos em atividades de extensão. Trata-se de uma extensão capaz de articular o ensino e a pesquisa de forma crítica, política e cidadã, sem abrir mão da qualidade técnica e do rigor epistemológico, ou seja, a Extensão Universitária, sob o princípio constitucional da indissociabilidade entre ensino, pesquisa e extensão, é um processo interdisciplinar educativo, cultural, científico e político que promove a interação transformadora entre universidade e outros setores da sociedade (FORPROEX, 2010).

Essa exigência e definição remetem a uma concepção orgânica de universidade vinculada à concretude das demandas socioculturais. Trata-se de uma práxis trans/formadora, democrática e exigente, que demanda re/ inventar e descolonizar a relação com a sociedade, como salienta Silveira (2009, p.4):

para se alcançar o campo de ação concreta da renovação da história, é necessário que o intelectual saia do confinamento institucional e profissional; afinal para que servem a universidade e as ciências sociais se não estiverem à serviço dos homens comuns na crítica e na reconstrução da sociedade?

Essa inclusão da exigência mínima de atividades de extensão, que deverá ocorrer até 2020 , demandará revisão curricular, revisão conceitual e metodológica de ensino e de pesquisa, bem como nas resoluções que tratam dos concursos e progressão na carreira. Assim, pode possibilitar benefícios múltiplos como: a atualização dos conteúdos em diálogo com a realidade social, perfil dos docentes e discentes comprometidos com transformações sociopolíticas e culturais, pesquisas com relevância social e socialização das mesmas, bem como o fortalecimento da sociedade civil organizada para fazer frente à fragilidade contemporânea da democracia representativa. 
As experiências brasileiras conhecidas e consolidadas da inclusão da extensão no currículo de todos os cursos de graduação ocorre, desde 2013, na Universidade Federal do Rio de Janeiro e na Universidade Federal de São Carlos - São Paulo. Entre os benefícios dessa inclusão recente, as Universidades já destacam o perfil dos egressos, socialmente mais comprometidos, e a redução de evasão, uma vez que o acadêmico é envolvido, desde o início do curso, em atividades que o aproximam da realidade. Muitas outras Instituições Públicas e P rivadas são referencias, porém, nessas, a inclusão da extensão se dá em cursos isolados.

Para facilitar a efetivação do desconfinamento e descolonização universitária e objetivação do princípio da indissociabilidade entre ensino-pesquisa-extensão, optamos pela mediação educomunicativa que facilita e potencializa o diálogo entre teoria e prática, conhecimento científico e conhecimento popular de forma inter/transdisciplinar, inter/transcultural e midiatizada.

\section{Mediação Educomunicativa}

Para a efetivação do princípio da indissociabilidade entre ensino-pesquisa-extensão sob a mediação educomunicativa que viabiliza a "educação como prática de liberdade”, como pretendia Freire (1999), temos como principais interlocutores desse processo a Universidade, os professores, os acadêmicos e a comunidade, cuja relação demanda uma mediação crítica, política e dialética, diferente da educação tradicional e colonial e da alienante e unilateral comunicação hegemônica. Esse cenário relacional reafirma a opinião de Freire (1999, p. 69-70), quando declara que "a educação é comunicação, é diálogo [...] um encontro de sujeitos interlocutores que buscam a significação dos significados”. Já, na visão de Kaplún (1999), essa mediação dialógica de uma comunicação educativa tem potencial para transformar e promover o sujeito social e politicamente, ou seja, emancipá-lo.

Assim, a partir de Fereire e Kaplún e dos principais autores da educomunicação, como Soares (2011) e Citelli (2011), temos que a educomunicação é um campo interdisciplinar que carrega no seu cerne a ação interventiva na realidade cotidiana de ambientes formais, não formais e informais de aprendizagem. Para tanto, apropria-se de uma gestão horizontal e colaborativa, respeitando e potencializando as singularidades e as pluralidades dos participantes do processo comunicativo e educativo, desencadeando uma trans/formação gradativa nos sujeitos através do direito à livre expressão e a comunicação. Esse processo dialógico e emancipatório ocorre porque a educomunicação proporciona abertura 
de espaços para inclusão equitativa da diversidade de indivíduos que têm, muitas vezes, suas subjetividades adormecidas e seus saberes ignorados pela educação e pela comunicação tradicional e colonial. Essa forma relacional, fluida e democrática de educar comunicando e de comunicar educando proporciona a insurgência de sujeitos críticos e políticos que desejam intervir na realidade ao invés de sofrer intervenção da mesma, que já se apresenta editada pelas convenções sociais e pela mídia hegemônica e colonialista.

Portanto, essa metamorfose emancipatória ocorre porque, nos processos educomunicativos, há liberdade e espaço para proposições e suposições, consensos e dissensos, que, na opinião de Soares (2009), impulsionam o repensar de atitudes e de discursos e a re/significação de valores e subjetividades que resultam em autonomia no pensar, no interagir e no intervir. Essas condições e experiências possibilitam o desenvolvimento da individualidade e o reconhecimento da alteridade. É nesse exercício relacional que, segundo Canclini (2009, p. 42), "aprendemos a ser interculturais" e, segundo Larrosa (2011)), vivenciamos a "experiência da alteridade".

A partir desse reconhecimento de si e da alteridade, temos um ambiente propício a aprendizagem inter/transcultural que remete ao saber da "compreensão humana”, tido por Morin (2000) como indispensável para a educação contemporânea. Essa “compreensão humana” que não se confunde com tolerância, encontra, nos processos educomunicativos e ecossistemas comunicativos, um ambiente propício a seu afloramento. Até porque, para Morin (2000), a compreensão constitui-se em meio e fim da comunicação humana. Assim, pensamos que a compreensão humana - que é também política - é que agencia a tessitura dialógica de sujeitos, comunidades, ideias e significados que emergem em todo o processo educomunicativo. Trata-se de uma compreensão humana e política objetiva voltada a re/conhecer, problematizar e interligar o singular e o plural, o científico e o popular, a universidade e a comunidade, o local e o global.

Nessa perspectiva, a educomunicação pode dar conta de uma mediação compreensiva, inovadora e democrática de integração entre ensino -pesquisa-extensão, mas também de trans/formação política e cidadã, principalmente pela sua natureza dialógica e plural, pois se trata de um espaço de interação, de negociação e de entendimento discursivo, ou seja: "um campo de ação política, entendida como o lugar de encontro e debate da diversidade de posturas, das diferenças e semelhanças, das aproximações e distanciamentos”, como salienta Donizete Soares (2009, p. 4). Assim, como espaço democrático para o dialógo intercultural e para "experiência da alteridade" pode desencadear mutações plurais, como veremos a seguir.cultura 


\section{Das monoculturas às ecologias}

A mediação educomunicativa voltada a objetivar o princípio de indissociabilidade entre ensino-pesquisa-extensão pode contribuir para a travessia de uma cultura universitária - no singular - para uma cultura pluriversitária - no plural. Para refletirmos sobre essa possibilidade, recorremos aos conceitos de sociologia das ausências e das ecologias de Souza Santos (2007).

A "sociologia das ausências" remete a formas de descartar e produzir invisibilidade a alternativas e saberes deslegitimados pela sociedade hegemônica. A produção de ausências, segundo o autor, dá-se por meio de cinco monoculturas: monocultura do saber e do rigor; monocultura do tempo linear; monocultura da naturalização das diferenças; monocultura da escala dominante; e monocultura do produtivismo capitalista. Como alternativa a essas monoculturas, Souza Santos (2007) propõe substituí-las por ecologias: dos saberes, das temporalidades, do reconhecimento, da "transescala" e das produtividades. Essas ecologias são constituídas a partir de novas racionalidades insurgentes que visam transgredir e resistir a uma "razão indolente e preguiçosa”, predominante em muitas Universidades e Escolas.

No final da descrição de cada monocultura e ecologia, traremos significações dos acadêmicos da disciplina em estudo que sinalizam a ocorrência de intervenções e travessias.

A primeira monocultura a ser quebrada é a do "saber e do rigor" que concebe como único saber credível o científico, ignorando os alternativos e produzindo o que o autor identifica como "epistemicídio", ou seja, a morte dos outros conhecimentos, e assim "reduz realidade porque 'descredibiliza' não somente os conhecimentos alternativos, mas também os povos, os grupos sociais cujas práticas são construídas nesses conhecimentos alternativos" (SOUZA SANTOS, 2007, p. 29). O revés a essa monocultura é uma "ecologia de saberes", que pressupõe compreender a ciência em diálogo e como parte de um ecossistema mais amplo de conhecimentos, isso porque "o importante não é ver como o conhecimento representa o real, mas conhecer o que determinado conhecimento produz na realidade; a intervenção no real" (SOUZA SANTOS, 2007, p. 33). No processo vivenciado na disciplina de Comunicação e Cidadania, procuramos valorizar os saberes que emergiram dos acadêmicos, da comunidade, dos representantes de movimentos sociais e da própria travessia, mesmo que por vezes tais saberes se apresentavam difusos e fragmentados, carecendo de uma mediação para sistematizar e contextualizar. 
As narrativas a seguir sinalizam a travessia dos acadêmicos da monocultura do saber e do rigor para ecologia dos saberes:

Durante as aulas fui sentindo uma mudança em mim, principalmente no momento em que começamos a executar o projeto sobre sustentabilidade com a troca e compartilhamento de saberes com as crianças da Escola. Sinto que vou levar esse conhecimento para fora da Universidade. Aprendemos diferentes e importantes conceitos e os analisamos em exemplos práticos e o que mais me "marcou" foi o de "minoria", como é "fácil" de entender na teoria, mas como é complexo compreender na prática social em meio a múltiplas carências (S.T.).

Sinto que, por vezes, nos iludimos por viver em um ambiente acadêmico. Tudo em ordem e perfeito, mas vejo que não passa de mentira, sim, mentira. Essa disciplina me fez ver que há mais coisas fora daqui, que não é porque tudo parece estar de acordo com os conceitos estudados que de fato está tudo bem. O mundo não é só aqui nessa bolha chamada UFSM. Não precisamos ir longe para vermos discriminações, preconceitos e problemas sociais diversos que nos circundam. Um exemplo é a escola onde nossa equipe desenvolveu o projeto, crianças em estado de vulnerabilidade social, e confesso que, neste período, mais aprendi com elas do que ensinei. Aprendi que o mundo está cheio de crianças iguais a elas e que eu, como ser humano, não posso ser hipócrita de voltar para sala de aula e fingir que o problema foi resolvido. Aprendi a ir além, pois, de teorias, este mundo está cheio, e não resolvem problemas sociais, precisa também da prática (M. F.).

Além de proporcionar leituras e debates relevantes sobre a sociedade e o viés cidadão da nossa profissão, a disciplina possibilitou compreender o mundo e as relações sociais e culturais de forma mais crítica e política que em outros ambientes de convívio social. No espaço da sala de aula, foi possível indagar e debater com liberdade e igualdade as temáticas sociais trazidas. Porém, mais relevante é o modo como o conhecimento aprendido em sala de aula é compartilhado e transformado em projetos que promovem a cidadania. Acredito que o conhecimento só é válido se for compartilhado em instâncias comunitárias (D.T.G.).

A disciplina trouxe temáticas sociais atuais, como a luta das minorias pelos seus direitos e a cidadania planetária. Minha equipe optou trabalhar a temática ambiental em uma Escola Municipal. Essa aproximação entre estudantes universitários e estudantes de Escolas Públicas fortificam o papel cidadão tão pouco exercido pelo aluno do ensino superior, a começar pela inserção curricular. Aposto muito nesse projeto como forma de retorno que devemos dar à sociedade, por estudarmos em uma Universidade Pública (G.B.).

A aprendizagem da disciplina me tornou mais completo como profissional, pois nos colocou em contato direto com a sociedade, e o 
entendimento dessa sociedade parte de ter um olhar crítico e político sobre a realidade. Na área pessoal, a oportunidade de realizar o projeto prático significa um marco, pois nunca tive um contato tão estreito com crianças em situação de vulnerabilidade social e isto foi determinante para ampliar minha reflexão sobre questões sociais (L. M.).

O segundo rompimento sugerido por Souza Santos (2007) é o da "monocultura do tempo linear", que impõe, globalmente, o tempo do capitalismo e da cultura ocidental. Para contrapor essa monocultura, ele sugere a "ecologia das temporalidades", que implica compreender que muitas culturas (indígena, agricultor...) têm diferentes tempos. No caso em estudo, podemos citar dois exemplos nos quais essa ecologia se fez presente: 1. um dos grupos, que optou por trabalhar com uma comunidade LGBT, teve que se adaptar a outra realidade considerada residual. A equipe propôs trabalhar no turno da manhã, mas a comunidade tinha disponibilidade apenas no horário vespertino, ou seja, fora do horário da aula, uma vez que, como profissionais do sexo, as travestis trabalham à noite e, por isso, durante o dia, necessitam descansar e dar conta de afazeres pessoais; 2. como os acadêmicos construíram vínculos com as comunidades através dos encontros semanais, frequentemente elas entravam em contato com as respectivas equipes, através das redes sociais, em dias e horários extra-aula para consultar ou relatar algo sobre o andamento dos projetos. Assim, os acadêmicos assumiram a responsabilidade de dar conta desses outros tempos; 3. c

Como terceira monocultura, temos a "naturalização das diferenças", que ignora as relações hierárquicas de poder e os interesses obscuros e hegemônicos que mantêm as minorias em condição de inferioridade através de representações discriminatórias e estereotipadas. Para desconstruir essa naturalização, Souza Santos (2007, p. 35) propõe a "ecologia do reconhecimento", que demanda "descolonizar nossas mentes para poder produzir algo que distinga, em uma diferença, o que é produto da hierarquia e o que não é. Somente devemos aceitar as diferenças que restem depois que as hierarquias forem descartadas". Nossa vivência da "ecologia do reconhecimento" se deu no exercício de desconstrução de estereótipos e preconceitos calcados em relações coloniais e no exercício de re/construção de uma relação dialógica com o outro - diferente.

A seguir, narrativas de acadêmicos que sinalizam a travessia da monocultura "naturalização das diferenças" para a "ecologia do reconhecimento":

Durante a primeira aula, uma simples observação feita pela professora me fez pensar sobre o papel que desempenho. Ela enfatizou que estamos em um curso de comunicação SOCIAL. Tive a oportunidade de 
ir a campo democratizar a comunicação com grupos marginalizados, transexuais, de um alojamento na cidade de Santa Maria que oferece moradia a essas pessoas. Considero este trabalho como um dos mais importantes que fiz durante a graduação. A oportunidade de trabalhar com pessoas que não fazem parte do meu cotidiano e que vivem à margem da sociedade me fizeram perceber o quão pouco sei sobre as diferentes esferas da sociedade e a cidade onde vivo. No entanto, pude aprender, na prática, no exercício da humildade e da persistência, a quebrar alguns estereótipos. Percebi a importância de uma comunicação horizontalizada e participativa na sala de aula e na relação com a comunidade para o exercício da expressão, manifestação e construção de uma cidadania e democracia participativa (R. A.).

Provocou-me muitos questionamentos e trouxe novos olhares sobre a representação da mídia e sobre questões sociais que passavam despercebidas, como a intolerância com as diferenças. Aprendi importantes conceitos, como o de cidadania planetária, que me faz pensar na necessidade de sermos solidários no acolhimento de estrangeiros, como está ocorrendo, no Brasil, a chegada de haitianos e senegaleses. Como profissional, a disciplina apurou meu olhar crítico sobre as questões políticas e sociais, por exemplo, para as discriminações, às vezes explícitas, que ocorrem em campanhas publicitárias. Além disso, proporcionou o conhecimento e contato com outras realidades que passa a fazer parte de uma pessoa mais atenta as questões referentes aos direitos humanos e de cidadania (R.P.).

Entre os conhecimentos que adquiri, o mais importante e que vou levar para a vida é que a comunicação é um direito de todas as pessoas e, como nem todos conseguem exercer, cabe a nós profissionais lutar para democratizar nossa área. As aulas me proporcionaram reflexões importantes acerca da responsabilidade social dos comunicadores, como, por exemplo, o cuidado e o dever de garantir a ausência de preconceitos e discriminações nas produções. Me proporcionou também conhecer novas formas de fazer comunicação e despertou-me para uma visão mais crítica do mundo, acrescentando na minha formação como profissional e como cidadão (A. S.).

Aprendi a olhar os movimentos sociais com respeito ao invés de tolerância. Percebi a importância que os projetos sociais têm para garantir maior igualdade de oportunidades e também como é marcante a experiência de participar de um projeto e constatar o poder da comunicação na transformação da vida das pessoas (C. P).

O ponto que achei mais importante da disciplina foi o projeto prático onde vivenciamos os conceitos estudados sobre cidadania, no caso de nossa equipe, em um alojamento para o público LGBT. Pude perceber o quanto criamos e alimentamos estereótipos e preconceitos por 
falta de conhecimento das pessoas que são diferentes. E com o projeto tivemos que desconstruir essas imagens negativas e os conceitos trabalhados em aula foram de grande ajuda. Em relação a L., como pessoa, humana, muitos conceitos e debates que tivemos contribuíram para rever meu papel como comunicadora cidadã (L.F.).

Outra monocultura identificada por Souza Santos (2007) é a da "escala dominante", que se dá por meio do universalismo e globalização. O foco na comunicação hegemônica e colonialista que ainda é forte nos cursos de comunicação pode representar essa monocultura a partir do momento que exclui ou reduz, assimetricamente, metodologias e espaços para a inclusão de outras formas de ser comunicador e produzir comunicação, direcionando o sujeito em formação à submissão do mercado. Para contrapor, o autor sugere a "ecologia das produtividades" que visa à valorização de sistemas alternativos de produção, explorando diferentes linguagens, metodologias, temáticas, públicos, espaços e tempos.

A seguir, narrativas de acadêmicos que sinalizam a travessia da "monocultura da escala dominante" para "ecologia das produtividades":

Trouxe-me conhecimentos não só profissionais, mas também sociais. Ajudou-me a descobrir campos alternativos de atuação como a educomunicação que podemos atuar de forma contra-hegemônica. Foi interessante a oportunidade de planejar, executar e avaliar um projeto social onde conseguimos por em prática os conceitos trabalhados em aula (J.C.).

Parece que foi ontem que esse acadêmico ingressou na Faculdade curso de Publicidade e Propaganda - desejando aprender a fazer campanhas que proporcionassem alto retorno financeiro, como toda pessoa (penso eu) que escolhe esse curso vem com um pensamento: vou criar campanhas geniais com táticas de humor e emoção que vão persuadir o povo a comprar, no decorrer de disciplinas como essa, Comunicação e Cultura, fui ganhando um aprendizado para a vida em sociedade. Hoje, com certeza, desejo fazer campanhas que proporcionam consciência social. Os textos, debates e o projeto prático me ajudaram a enxergar o quanto o mundo é complexo e desigual, mas veio convergir com um pensamento que sempre carrego comigo: o que diferencia o ser humano é apenas o caráter e não o gênero, a classe, a cor ou religião (M.A.).

Devolver à sociedade. Esse é um conceito que eu já havia escutado, mas que só agora compreendo plenamente. Compreendi o que é de fato ser cidadão e participar da sociedade. Sou fotógrafo e posso dizer que conhecer histórias de outros profissionais que dedicam suas vidas a 
uma causa social ressoaram dentro de mim por meio do nosso projeto social. Ver o interesse dos adolescentes aprendendo algo que, provavelmente, não teriam oportunidade sem a minha contribuição é, ao mesmo tempo, satisfatório e triste, pois denunciam as desigualdades sociais no acesso às oportunidades. A Faculdade serve para isso: fazer o acadêmico enxergar o mundo por uma pluralidade de ângulos. Esta disciplina está me satisfazendo nisso, pois estou sendo desafiado em um nível muito pessoal, mesmo em uma turma de 60 alunos. Gostaria de mais oportunidades como essa (V.S.).

Proporcionou-me conhecer mais sobre a relação entre comunicação e cidadania e me despertou um maior desejo de participação social. Perceber que existem soluções e novas propostas para antigos problemas como a educação (educomunicação) me motivaram e instigaram a refletir sobre meu papel como comunicadora social. O projeto prático permitiu trabalhar a educomunicação com o público infantil sobre a temática de gênero que tem grande importância social para redução de preconceitos (G.R.).

Questionar a nossa própria área, conceber a comunicação, não só como consumo, mas como um direito e tomar consciência de nossa responsabilidade frente à sociedade foram as questões que julguei mais importantes. As temáticas trabalhadas na disciplina me despertaram para desmistificar a ideia de que a Publicidade é única e exclusivamente mercadológica e capitalista. Quero ser, antes de tudo, uma comunicadora social (T. E.).

Trouxe à tona temas importantes para rever o meu papel de comunicador e de cidadão. Destaco como aprendizagem maior a implantação do projeto que realizamos na Escola Municipal Duque de Caxias, voltado à educomunicação ambiental, onde tivemos que utilizar a sensibilidade para incluir a diversidade de crianças, inclusive uma com autismo (T.R.).

Como profissional, levo a abertura e a crítica ao campo publicitário, o leque de atuação, podendo me distanciar das agencias tradicionais e me aproximar das mais voltadas à produção cultural. Como pessoa humana, esse aprendizado teórico e prático só reafirma valores e crenças necessárias para ajudar a transformar o mundo em um lugar mais democrático e com maior liberdade para a pluralidade de pessoas existentes. Como homossexual, ainda é um choque a distinção entre ser "assumido" ou não. A própria afirmação se torna um ato político e assim uma batalha diária por direitos iguais aos demais. Essa luta me torna um ativista e me aproprio dos conhecimentos dessa disciplina para legitimar a necessidade de continuar a luta (G. G.). 
A última monocultura apontada por Souza Santos (2007) é a do "produtivismo capitalista", que exclui economias alternativas e, no caso em estudo, pode ser sustentado por determinado tipo de formação que prioriza a comunicação comercial. O resultado são egressos despidos de ethos político, com baixo nível de criatividade e criticidade. Como revés, o autor sugere a "ecologia da "transescala", que consiste na possibilidade de articular projetos em escalas locais, nacionais e globais. Essa ecologia foi exercitada na disciplina em análise com a produção de recursos educomunicacionais disponibilizados em rede no Repositório Internacional de Recursos Educativos do MEC e no repositório da EduMIX - Editora Aberta do Curso de PE e que integra o Mapa Global dos REA - MIRA. Essa socialização possibilita a professores e alunos de diferentes escolas, universidades, cidades, estados e países o acesso e o exercício da co/autoria através de produção individual ou colaborativa com o surgimento de obras derivadas, resultando em um ecossistema comunicativo. Outro exemplo é o Programa de Ensino, Pesquisa e Extensão Educomunicação e Cidadania, em desenvolvimento na UFSM e Escolas Públicas de Santa Maria desde 2010, coordenado por essa pesquisadora e que será expandido para Moçambique (2016 e 2017), em parceria com a Universidade Pedagógica daquele país e financiado pelo Edital Abdias Nascimento.

5Abaixo, as narrativas de acadêmicos que sinalizam a travessia da monocultura do "produtivismo capitalista" para uma "ecologia da "transescala":

Agregou muito em minha vida pessoal e profissional. Os debates em sala de aula e o projeto prático abriram outros horizontes e interrogativas em minha vida, cruzando com conhecimentos adquiridos em outras disciplinas e em atividades extra-sala. Fez-me questionar muitos fatores enraizados em nossa sociedade e que pouco são questionados. Levo esses questionamentos para o Grupo PET CISA (Programa de Educação Tutorial) do qual sou integrante. Pensar o social e preocuparse com comunidades populares é fundamental em nossa formação, e, nos vários ambientes que circulo, percebo que essa preocupação não é exclusividade da comunicação. Acredito que trabalhar de forma conjunta e interdisciplinar é importante para o fomento à cidadania. (C.P.).

Sou oriundo de uma Escola Pública da periferia de Santa Maria e confesso que fiquei fascinado pela proposta da disciplina de unir o ensino, a extensão e a pesquisa. Eu me enxergo hoje com outra visão do mundo pela perspectiva dos direitos. Muito debati neste semestre e levei

5 http://w3.ufsm.br/educomufsm/ 
informações para meus antigos colegas que não tiveram a oportunidade de estar no ensino superior. É incrível poder compreender melhor a sociedade em que estou inserido e de alguma forma poder devolver este conhecimento. Ensinei, mas também aprendi. Tenho a dizer que fiquei encantado com nosso projeto de Comunicação na Escola, poder contribuir com a formação do ser humano para crescer respeitando as diferenças (V.N.).

Me fez abrir os olhos para muitas questões que passavam batidas: as minorias, por exemplo. Aos poucos, fui me abrindo para me questionar e, quando percebi, estava levando estas reflexões para amigos de fora do curso e para a família. Foi ali que percebi como a sociedade está despreparada para debater sobre diversidade. Esta perspectiva é o maior legado que eu levo desta disciplina. Compreender essas questões me fez evoluir como pessoa, repensar valores e atitudes. Além disso, o projeto prático com pessoas de outra realidade contribuiu para a construção de um J. mais liberto de estigmas sociais. A experiência teórico-prática foi inspiradora e transformadora. Não tinha noção de que em tão pouco tempo poderia haver tantas mudanças (J. P).

Apesar de as narrativas dos acadêmicos apresentarem um hibridismo de significações em relação às ecologias, ou seja, evidenciam a ruptura de mais de uma monocultura, por uma questão didática, optamos por inserir na de maior aderência. Assim, constatamos que a maior incidência ocorreu na ecologia do reconhecimento - "experiência de alteridade", seguida da ecologia das produtividades - campos alternativos.

Essas travessias das monoculturas às ecologias propostas por Souza Santos e experienciadas pelos acadêmicos viabilizam a passagem de uma cultura universitária no singular para uma cultura no plural. Para Certeau (2008), a cultura plural se constitui em um campo de luta entre o instituído e o flexível, uma vez que, para haver cultura, as práticas sociais precisam ter significado para quem as realizam. O significado descrito pelos acadêmicos é uma invenção de cada sujeito que demandou um querer político para experienciar a cultura e o saber do outro (comunidade), flexibilizando o sentido instituído pela Universidade ou professores.

A cultura no singular é compreendida por Silva (2009) como prejudicial à criação, à invenção e à intervenção. Assim, ela defende que é preciso permitir que os diversos sistemas de referências e significados silenciados na educação colonial sejam aflorados para evidenciar a riqueza da pluralidade cultural dos sujeitos que integram a comunidade educativa, principalmente professores e alunos, a exemplo do que ocorreu na travessia da monocultura do rigor científico para a ecologia de saberes. Isso aconteceu devido à re/ 
invenção na conexão entre conteúdos/temáticas e a relação didático-pedagógica: dialógica, horizontal, inventiva, colaborativa e significativa. Nesse sentido, Certeau (2008, p. 128) alerta para a necessidade de diagnosticar o tipo de relação e comunicação estabelecida na cultura cotidiana da educação:

Trata-se de saber se a relação é por si mesma produtora de linguagem ou se é canal pelo qual se "transmite" um saber estabelecido pelos professores; se a prática da comunicação deve intervir como determinante na criação da cultura escolar, ou se ela será uma técnica que visa aos consumidores de produtos fabricados pelas oficinas especializadas; ou ainda se haverá ruptura entre o saber e a relação social.

Temos aqui uma conexão direta entre a ideia de Certeau e os princípios educomunicativos, no sentido de que é impossível aceitar uma separação entre o saber e a relação educativa mediada por uma comunicação dialógica e plural. Ao problematizar o conteúdo do ensino e a relação pedagógica, o autor ressalta que a cultura no singular, sem espaço para participação, acaba suprimindo a pluralidade. Em outras palavras, temos que o conhecimento é relacional e comunicacional, uma vez que se constrói na relação dialógica entre sujeitos e campos. Constata-se, assim, a centralidade da comunicação, independente de ser essa uma experiência vivida no próprio campo, no processo de construção de uma cultura educativa plural.

O relato abaixo talvez possa sintetizar as significações e travessias da relação didático-pedagógica mediada pela educomunicação na disciplina em pauta:

As principais aprendizagens proporcionadas pela disciplina foram: 1. Despertar para um interesse político através, por exemplo, das discussões de como a mídia aborda a questão da redução da menoridade penal; 2. Problematizar a questão da luta de gênero e os direitos dos homoafetivos; 3. Consciência da necessidade de dar voz às minorias; 4. Consciência da necessidade de uma comunicação mais democrática e comprometida com as problemáticas sociais, uma comunicação que não reafirma os discursos hegemônicos e que desconstrói o senso comum e os padrões preestabelecidos e carregados de preconceitos; 5 . Compreensão profunda da importância que a comunicação e a informação têm nas organizações sociais e na vida das pessoas como cidadãs; 6. Maior valorização da comunicação alternativa e maior engajamento a assuntos relacionados à luta contra-hegemônica da comunicação. Enfim, a disciplina trouxe, de forma ética, reflexões e vivências acerca de temas que não estamos acostumados a discutir e muito menos de ver na televisão (G.P.). 
Nesse exercício dialético de empatia (docente-discente), que, para Kaplún (1998, p.99), significa mais do que se colocar no lugar do outro, significa "querer, valorizar aqueles com quem tratamos de estabelecer uma comunicação", é possível identificar marcas narrativas que remetem à intervenção e à insurgência de "subjetividades rebeldes", assumindo o lugar de "subjetividades conformistas" (SOUZA SANTOS, 2007) presentes no início do processo.

Percebe-se o nível de conscientização dos acadêmicos quanto às problemáticas abordadas teoricamente e re/apropriadas no projeto prático. Desenvolveram múltiplas aprendizagens, tais como habilidades interpessoais e interculturais, o cultivo de valores e atitudes altruístas em relação a si mesmos, aos colegas e à comunidade e o aprimoramento da compreensão humana frente à diversidade. Freire diria que houve uma "dialogisidade verdadeira"; Souza Santos, "uma ecologia de saberes"; Larrosa, uma "experiência de alteridade"; e Certeau, uma "cultura plural", na qual os acadêmicos construíram seus conhecimentos, processos e produtos, respeitando e dialogando com outras racionalidades, saberes e realidades.

A partir das percepções dos acadêmicos, podemos inferir que a experiência de aprendizagem da disciplina de Comunicação e Cidadania e Docência Orientada, que seguiu o princípio da indissociabilidade entre ensino-pesquisa-extensão, mediada pela educomunicação, possibilitou que os participantes rompessem monoculturas enraizadas e despertassem e manifestassem um interesse, uma energia, um saber, uma criticidade e politicidade muitas vezes adormecida por uma educação colonialista.

Apesar de não relatados, por meio da observação participante e das assessorias às equipes, foi possível identificar e mediar alguns temores, estranhamentos, reclamações e conflitos ocorridos entre os integrantes das equipes e/ou com integrantes das comunidades. Das 11 equipes constituídas, uma teve que mudar de público devido à linha tradicional da direção da escola, que temia a repercussão, na escola e nas famílias, da abordagem comunicativa sobre gênero; outra equipe teve que mudar de temática e comunidade porque dois integrantes desistiram da disciplina (estranhamento metodológico), o que acabou inviabilizando a proposta inicial e uma terceira teve que flexibilizar o plano de ações para atender aos interesses da comunidade que optou, durante o processo, por aprofundar mais uns aspectos do que outros.

Apesar do planejamento contextualizado, relembrando Certeau (2005), foram necessárias estratégias e táticas por parte de cada equipe para flexibilizar e objetivar as ações, respeitando singularidades de cada comunidade. No distanciamento da Universidade, a maioria das equipes lançou 
mão, com autonomia, de estratégias sensíveis, discretas e qualificadas, umas mais que outras, bem como uns integrantes mais que outros, que permitiram negociar e flexibilizar o desenvolvimento e a participação da comunidade no projeto, superar ou minimizar obstáculos de diferentes ordens como: de tempo, burocracia, de infraestutura física, humana e financeira, bem como administrar as relações internas entre a equipe e a comunidade. Assim, os espaços de interação foram se re/construindo pelas ações, negociações e apropriações dos acadêmicos e da comunidade. Negociando e flexibilizando, conseguiram desenvolver os projetos e produzir sentidos às suas práticas, conforme foi possível constatar nos depoimentos.

Portanto, o conhecimento construído na Universidade, por meio dessa articulação entre ensino-pesquisa-extensão, dinamiza-se, pluraliza-se, politiza-se e se socializa como decorrência da relação entre o conhecimento científico, o conhecimento dos acadêmicos e os comunitários, mediados pela educomunicação, que proporciona a formação e ou fortalecimento de "ecossistemas comunicativos" e de uma "ecologia de saberes" na qual os sujeitos participantes se reconhecem como integrantes de uma rede de aprendizagem cidadã e democrática.

Por fim, a partir de nossa experiência, admitimos que há disciplinas que facilitam a efetivação do princípio da indissociabilidade tais como: na graduação, os projetos experimentais e os de cunho humanístico e cultural; na pós-graduação, a disciplina de Docência Orientada. Possibilitam tornar a Universidade acessível à sociedade, independente das pessoas que frequentam os cursos regulares, ou seja, viabilizam agregar no mesmo campo: a Universidade, a Escola, o Estado, Instituições, ONGs e a comunidade. Assim, a sociedade beneficia-se e a extensão retorna em relevância das pesquisas, melhoria do ensino, do perfil do egresso e dos docentes. 


\section{Referências}

CANCLINI, Nestor. Diferentes, desiguais e desconectados. Rio de Janeiro: UFRJ, 2009 .

CERTEAU, M. de. A cultura no plural, 5. ed. Campinas, SP: Papirus, 2008.

. A invenção do cotidiano: 1. artes de fazer. Petrópolis: Vozes, 2005.

CITELLI, A. O; COSTA, M. C. C. (Orgs) Educomunicação: construindo uma nova área de conhecimento. São Paulo: Ed. Paulinas, 2011.

FORPROEX. Plano Nacional de Extensão Universitária. Coleção Extensão Universitária. vol. I, 2001.

FREIRE, P. Pedagogia da Autonomia: saberes necessários à prática educativa. $23^{\mathrm{a}}$ ed. São Paulo: Ed. Paz e Terra, 2000.

. Extensão ou comunicação? $8^{a}$ ed. São Paulo: Ed. Paz e Terra, 1985.

Educação como prática de liberdade. Rio de Janeiro: Ed. Paz e Terra,

1999.

KAPLÚN, M. Una pedagogía de la comunicación. I $^{a}$ ed. Madrid: Ediciones de la Torre, 1998.

. Processos educativos e canais de comunicação. In: Comunicação \& Educação. São Paulo, p.68-75, 1999.

KEMMIS, S.; McTAGGART, R. Cómo planificar la investigación-acción. Barcelona: Ed. Alertes, 1988.

LARROSA, J. Experiência e alteridade em educação. Revista Reflexão e Ação. Santa Cruz do Sul, v.19, n2, p.04-27, jul./dez. 2011

MOITA, F. M. G. S.C; ANDRADE, F. C. B. Ensino-pesquisa-extensão: um exercício de indissociabilidade na pós-graduação. Revista Brasileira de Educação. vol. $14 \mathrm{n}^{\circ}{ }_{41}$, Rio de Janeiro, May/Aug, 2009.

MORIN, E. Os sete saberes necessários à educação do futuro, São Paulo: Cortez; Brasília, DF: UNESCO, 2000. 
SILVA, S. K. Por que ter Michel de Certeau como referência? In.: Pós-Discente: Caderno de Prod. Acad. - Cient. Progr. Pós-Grad. Educação. v. 15. nº 1.Vitória, jan.-jul. 2009, p.84-93.

SILVEIRA, Z. S. da. A universidade brasileira e o papel do intelectual em Florestan Fernandes. 2009. Disponível em: <http://www.ifch.unicamp.br/formulario_cemarx/selecao/20og/trabalhos/a-universidade-brasileira-e-o-papel-do-intelectual-florestan-fernandes.pdf >. Consultado em: 7 jul. 2015.

SOARES, D. Educomunicação - o que é isto? 2009. Disponível em: <http://www. portalgens.com.br/baixararquivos/textos/educomunicacao_o_que_e_isto.pdf $>$. Consultado em: 12 jun. 2015.

A natureza política da educomunicação. 2006. Disponível em: <http:// www.portalgens.com.br/baixararquivos/textos/educomunicacao_o_que_e_isto. pdf $>$. Consultado em: 12 jun. 2015 .

SOARES, I. Educomunicação, o conceito, o profissional, a aplicação. São Paulo: Ed. Paulinas, 2011.

Educomunicação: um campo de mediações. In: CITELLI, Adílson Odair; COSTA, Maria Cristina Castilho. (Org.) Educomunicação: construindo uma nova área de conhecimento. São Paulo: Paulinas, 2011.

Artigo 227 da Constituição Federal (redação dada pela Emenda Constitucional no. 65 , de 2010)

SOUZA SANTOS, B. Renovar a teoria crítica e reinventar a emancipação social. São Paulo: Boitempo Editorial, 2007. Disponível em: <http://www.biblio.fae. ufmg.br/webbiblio/Bibliografiazo13_arquivos/renovarateoriacritica\%2oSantos\%20 $127 \%$ 20p.pdf $>$.

A universidade do século XXI: para uma reforma democrática e emancipatória da universidade. São Paulo: Cortez, 2004. 


\section{Educomunicação e Midiaeducação: um estudo comparativo entre as cidades de São Paulo e Rio de Janeiro ${ }^{1}$}

Elisangela Rodrigues da Costa ${ }^{2}$

Escola de Comunicações e Artes

Universidade de São Paulo, São Paulo, SP (ECA/USP)

\section{Introdução: do contexto contemporâneo à elaboração da pesquisa}

Mudanças ocorridas na atual sociedade, influenciadas pela amplitude do papel da Comunicação, requisitam uma forte integração entre os campos da Comunicação e Educação. Por meio de um resgate histórico e teórico, este artigo se propõe a apresentar políticas públicas de educação midiática desenvolvidas no Brasil. De um lado, o exemplo do município do Rio de Janeiro, com o educar para, com, pela e entre mídias, com práticas exclusivas à educação formal, ou seja, à escola, a partir da concepção de $M e$ dia Education europeia, abordagem da Midiaeducação carioca. De outro, com enfoque na concepção dialógica de Paulo Freire, Ismar Soares e autores latino-americanos, a educomunicação, em São Paulo, que propõe ações de intervenção, em espaços de educação formal, não-formal e informal, preocupados com os processos comunicativos.

1 Trabalho originalmente apresentado no GP Comunicação e Educação, Congresso INTERCOM, Rio de Janeiro, 2015. Texto atualizado para esta publicação.

2 Jornalista, pedagoga, sócia-fundadora da Associação Brasileira de Pesquisadores e Profissionais em Educomunicação (ABPEducom), diretora do Departamento de Formação Continuada Docente do município de Barueri, São Paulo. Mestre e doutoranda em Ciências da Comunicação pela Escola de Comunicações e Artes da Universidade de São Paulo (ECA/USP), sob a orientação do professor Dr. Ismar Soares e coorientação do professor Dr. Adilson Citelli. E-mail: lisacosta@usp.br. 
O pensador Jesús Martín-Barbero (1997) lembra-nos que uma das mais importantes constatações desta sociedade é o reconhecimento da comunicação como mediadora de todos os aspectos da vida social dos povos. Sob a influência dos Estudos Culturais, sobretudo a partir da pesquisa de Stuart Hall, discorre que vivemos numa sociedade que não tem centro, porque as identidades que eram centralizadoras do sujeito deixaram de sê-lo.

Hoje, a principal consequência da comunicação ocupar uma função estratégica no convívio societário é a admissão de novos ajustes nos mais diversos espaços sociais. Nesta proposta, a análise restringe-se ao ambiente educacional formal, tendo em vista a esfera das políticas públicas, por meio dos paradigmas da Educomunicação³, em São Paulo, e da Midiaeducação4, no município do Rio de Janeiro.Em sua obra A Mídia e a Modernidade, Thompson (2011) enfatiza a importância de se pensar nos meios comunicacionais em relação aos contextos práticos, nos quais os indivíduos produzem as formas simbólicas. O autor sustenta que o desenvolvimento da mídia transformou a constituição espacial e temporal da vida, criando novas maneiras de ação e interação, não mais ligadas ao compartilhar de um lugar comum.

Na obra A comunicação na educação, Martín-Barbero (2014a, p. 121) afirma que "vivemos numa época da passagem de uma sociedade com sistema educativo para uma sociedade do conhecimento e aprendizagens contínuas". Abarca a questão da crise educacional na América Latina e critica,

3 O conceito de Educomunicação é adotado na perspectiva do Núcleo de Comunicação e Educação da Universidade de São Paulo (NCE/USP). O paradigma (SOARES, 2002, p. 155) é definido como o conjunto das ações inerentes ao planejamento, implementação e avaliação de processos, programas e produtos destinados a criar e fortalecer ecossistemas comunicativos em espaços educativos presenciais ou virtuais, ou seja, a ênfase está nos processos comunicativos. A Educomunicação apresenta-se por meio de "áreas de intervenção" que hoje são sete: 1) Gestão dos processos e recursos da Comunicação nos espaços educativos; 2) Expressão comunicativa através das Artes; 3) Educação para a Comunicação; 4) Mediação tecnológica nos espaços educativos; 5) Reflexão epistemológica; 6) Pedagogia da Comunicação; e 7) Produção midiática para a Educação.

4 Por midiaeducação convém entender o estudo, o ensino e a aprendizagem dos meios modernos de Comunicação e Expressão, considerados como parte de um campo específico e autônomo de conhecimentos, na teoria e na prática pedagógica, o que é diferente de sua utilização como auxiliar para o ensino e a aprendizagem em outros campos do conhecimento, tais como a Matemática, a Ciência e a Geografia. (UNESCO, 1984). O conceito possui várias grafias, e adota-se, neste artigo, o termo sem hífen - Midiaeducação, adoção feita também pela MultiRio (Empresa Municipal de Multimeios), um dos contextos desta pesquisa. 
fortemente, a inserção desmedida da tecnologia como marca de uma suposta modernização na Educação. Entre as mudanças elencadas pelo autor que corroboraram para deslocar a instituição escolar e provocar sérios desafios e confrontos está o fato de que:

a educação já não é concebível a partir de um modelo de comunicação escolar que se encontra ultrapassado tanto espacial como temporalmente por processos de formação correspondentes a uma era informacional, na qual a idade para aprender são todas, e o lugar para estudar pode ser qualquer um: uma fábrica, uma casa para idosos, uma empresa, um hospital, os grandes e pequenos meios e especialmente a internet (MARTÍN-BARBERO, 2014a, p. 121).

Em outras palavras, o que se observa, nesta primeira década do século XXI, é o ingresso na instituição educacional formal, ainda organizada sob o ideal iluminista, de um "novo aluno", que olha, ouve, sente, sonha, percebe, fala de forma articulada, fragmentada e totalmente dependente das tecnologias.

Nesta (re)organização social, a escola e os meios comunicacionais vivem um embate permanente pela hegemonia na formação dos valores destes indivíduos, alimentando, assim, a briga pela preferência na configuração dos sentidos sociais.

Maria Aparecida Baccega (2011, p. 33) reforça a ideia de disputa entre as chamadas agências de socialização - mídia versus escola e família:

Com o objetivo de revestir de significados os signos em circulação: ou seja, cada agência considera-se, ela própria, a única capaz e correta nesse processo de atribuição de sentidos. E há permanentemente a tentativa - impossível, ainda bem - de tornar o signo monossêmico, ou seja, de pretender que o sentido atribuído à palavra por uma das agências, por exemplo, é o único e será interpretado apenas daquele modo por todos.

Para Baccega (2011), o êxito no complexo campo que ela designa de Comunicação/Educação deriva da superação de dez desafios; sendo três essenciais: 1) o reconhecimento dos meios como outro lugar do saber, atuando com a instituição escolar e outras, com vistas a socializar; 2) o cuidado para não reduzir a intersecção das áreas a fragmentos na discussão sobre a utilização dos aparatos tecnológicos no espaço educativo; 3 ) a consideração sobre como os sujeitos interpretam (em todos os âmbitos) as práticas midiáticas.

Baccega (2011, p.41) acredita que somente após ultrapassar os pontos conflituosos, a Comunicação/Educação estará apta a proporcionar aos 
alunos "uma produção que valorize aspectos da cultura em que se vive, que abra discussões sobre a dinâmica da sociedade, numa nova linguagem audiovisual, num novo mundo".

Resumidamente, este complexo cenário, marcado pela centralidade da comunicação, estabelece novos desafios à educação com vistas ao atendimento deste novo perfil de alunado. Reafirma assim, a urgência do uso das mídias no processo ensino-aprendizagem, ou seja, a Educação Midiática é requisitada, sobretudo na esfera das políticas, por sustentar práticas pedagógicas que atendam às necessidades das novas gerações de estudantes.

\section{Os meandros do artigo: o encaminhar da tese}

O artigo é um recorte de nosso projeto doutoral que está sendo desenvolvido no Programa de Pós-Graduação em Ciências da Comunicação da Escola de Comunicações e Artes da Universidade de São Paulo (PPGCOM/ ECA/USP), na área de Interfaces Sociais da Comunicação, na linha de pesquisa Comunicação e Educação.

A investigação parte de uma perspectiva transdisciplinar, consiste em um estudo comparativo sobre a existência de políticas públicas relacionadas à Educação Midiática em dois municípios brasileiros que possuem as duas maiores redes municipais de Educação do país: São Paulo e Rio de Janeiro. Entre os objetivos da pesquisa, a verificação acerca da forma que a Educação Midiática, em termos de ações de caráter governamental, está sendo administrada pelas gestões educacionais, nos referidos municípios, nas práticas pedagógicas. A problemática em questão é compreender: o que aproxima ou diferencia as políticas públicas de Educação Midiática implantadas nas cidades de São Paulo e Rio de Janeiro? O problema será analisado tanto sob suas perspectivas teóricas, quanto sob suas perspectivas de gestão.

$\mathrm{O}$ estudo comparativo-qualitativo, em andamento, ocorre por meio de análise documental e entrevistas semiestruturadas que foram categorizadas em quatro grandes núcleos: formação continuada docente e discente, gestão da Comunicação na prática pedagógica, legislação e política curricular - considerando os paradigmas da Educomunicação (SP), sob a perspectiva do NCE/USP, e a Midiaeducação (RJ) sob a influência da Media Education europeia.

Reafirmamos o propósito deste artigo: apresentar a Educação Midiática sob o olhar dos dois paradigmas difundidos no Brasil, em São Paulo 
e Rio de Janeiro, não desconsiderando a abordagem que a Organização das Nações Unidas para a Educação, a Ciência e a Cultura (Unesco) dissemina sobre o que chama de Alfabetização Midiática e Informacional (AMI). Sendo assim, neste texto, por meio de um resgate temporal necessário, serão apresentadas as fundamentações e percursos das práticas com a Educomunicação e Midiaeducação que, apesar de possuírem semelhanças, possuem diferenças de natureza histórica e metodológica, o que não impede um resultado final satisfatório e reconhecido no trato da Educação Midiática no ambiente educacional.

A partir de uma consciência progressiva, entendendo que a Comunicação é um campo que permite olhares múltiplos sobre os processos comunicativos e admitindo sua importância, sobretudo, nos países da América Latina, Martín-Barbero (1996, p. 62) destaca que: “a transdisciplinaridade de modo algum significa a dissolução dos problemas do campo da comunicação nos de outras disciplinas sociais, mas a construção de articulações - intertextualidades”. Conforme a introdução, os contextos históricos são fundamentais para o entendimento das práticas Educomunicativas e Midiaeducativas, respectivamente, adotadas nas redes municipais de São Paulo e no Rio de Janeiro.

\section{Os contextos da Educação Midiática: da Europa à Améri- ca-Latina}

Nos anos 1980 foi que o tema da Educação para a Comunicação ganhou relevância em todo o mundo, sob a liderança da Unesco. Congressos foram realizados e seminários continentais promovidos com o objetivo de difundir referenciais e metodologias de análise. No contexto de tradição europeia, são válidas as contribuições de Célestin Freinet e da própria Unesco. Afinal, hoje, existe a abertura de um novo espaço propondo a alfabetização midiática a todos os cidadãos, de acordo com o Convênio assinado por representantes da Comunidade Europeia, na Bélgica, em dezembro de 2010 (DI MELE , 2011, p. 117-121).

A partir de então, discussões sobre práticas de Educação Midiática, "sobre" e "com" a mídia estão, cada vez mais, recorrentes em todo o mundo. Inúmeros exemplos, no Brasil e em toda a América-Latina, sem contar na Europa e até África, comprovam esta assertiva. Vale destacar o lançamento, em português, do manual Alfabetização Midiática e Informacional: currículo 
para formação de professores (UNESCO-UFTM, 2013)5 e também do V Encontro Brasileiro de Educomunicação, em São Paulo, em 2013, que elegeu esse assunto como central.O citado manual da AMI-Unesco propõe a difusão de metodologias de ação neste campo. Parte, assim, do pressuposto de que o fortalecimento deste tema entre os alunos requer que os próprios educadores sejam alfabetizados em mídia e informação.

A referida matriz curricular do documento está ancorada em três áreas temáticas centrais: 1) o conhecimento e a compreensão das mídias e do sistema mundial de informação; 2) avaliação dos textos e produtos culturais produzidos pela mídia; e 3) uso autogestionado dos meios para a produção de mensagens de interesse para a comunidade.

Enfim, as bases das articulações da Unesco sobre a temática dialogam com a concepção europeia de Media Education, além das referências pertinentes sobre a Media Literacy, dos Estados Unidos.

\section{As Contribuições Europeia e Americana: Media Educa- tion e Media Literacy}

O desenvolvimento da prática de Midiaeducação intensificou-se nas primeiras décadas do século XX, em paralelo à formação da chamada indústria cultural, muito mais sob um olhar educativo, confrontando-se com as mensagens midiáticas, do que como um movimento estruturado. Neste cenário, as mídias eram interpretadas como uma espécie de "bicho papão", a serem combatidas pela educação, o que provocava reações negativas por parte dos professores.

A Igreja Católica, a partir do apoio do Papa Pio XI à produção cinematográfica, exigiu que cada escola ou paróquia católica disponibilizasse um salão exibidor de filmes (SOARES, 1988, p. 123).

Neste sentido,

a ação propiciou a expansão da prática de cineclubismo como exercício de leitura crítica da mídia em todo o mundo. A contribuição da Igreja Católica associou-se, neste início, à vertente moral de abordagem da educação midiática. O cuidado com os possíveis malefícios das mensagens

5 Disponível em <http://unesdoc.unesco.org/images/o022/002204/220418por.pdf>. Acesso em 20 mar. 2015. 
cinematográficas justificava, por exemplo, a prática da classificação moral dos espetáculos, sustentada na teoria dos efeitos, pela qual o sistema educativo atribuía grande poder manipulatório aos meios de informação na difusão de suas mensagens (SOARES, 2013, p.173).

Ainda nesta década, outras ações ocorreram na Inglaterra, em três momentos: no primeiro, a British Film Institute (BFI) iniciou o exercício de análise sistemática do cinema como conteúdo cultural de interesse para a Educação, um dos primeiros e mais antigos programas na esfera das políticas públicas voltadas à Educação para os meios.

A corrente teórica dos Estudos Culturais marcou o segundo momento deste movimento, na Grã Bretanha, com as contribuições de Raymond Williams.

Williams é um autor fundamental na construção dos percursos deste grupo. O teórico acredita que a questão cultural é a categoria-chave entre análise literária e investigação social. Em The Long Revolution (1961), discorre sobre a relação contemporânea e o impacto dos meios de comunicação, aproveitando para demonstrar seu pessimismo, tanto com relação aos meios, quanto no que se refere à própria cultura popular.

O terceiro e último movimento que se destacou, ainda na Inglaterra, é marcado pela ideia de renovação da Media Education, a partir das pesquisas de Len Masterman, que defende

um processo de educação continuada, visando não apenas uma inteligência crítica, mas sobretudo uma autonomia crítica - para fora da sala de aula, para o futuro, para a vida. Masterman enfatiza, em seus escritos, a educação política, levando em conta que, em uma democracia, a maioria das decisões são tomadas com base na presença dos meios e sua influência sobre os cidadãos e eleitores. Para ele, a educação para os meios deve ser avaliada em termos da redistribuição política e social do poder. É importante lembrar que, no campo metodológico, o pesquisador inglês apoia-se no enfoque filosófico de Paulo Freire, valorizando o diálogo, a reflexão e a ação, entendidos de uma forma dialética (SOARES, 2013, p. 174).

De acordo com os pesquisadores da Midiaeducação, uma abordagem ampliada conceitual pode ser entendida a partir de três perspectivas: educar sobre/para os meios (perspectiva crítica), com os meios (perspectiva instrumental) e através dos meios (perspectiva expressivo-produtiva).

Neste contexto europeu, sem dúvidas, poderíamos citar outros países: Espanha, Itália, Suécia, com inúmeras experiências importantes. Contudo, a 
pesquisadora francesa Jeveniève Jacquinot, professora da Sorbonne, alerta que algumas contradições estão presentes nas práticas pedagógicas, sinalizando a urgência de renovação da educação para os meios. Para tanto, alerta que:

\begin{abstract}
Hoje a distinção e/ou separação entre educar para e com os meios - em que de um lado existe a prática educativa sobre os meios e de outro o ensino através dos meios - esconde certa "esquizofrenia" nas suas funções, pois embora sejam voltadas para diferentes tipos de práticas, as ações de formação propostas em ambos os casos caminham na mesma direção (JACQUINOT, 2006, p. 3).
\end{abstract}

Jacquinot (2006, p. 9) concilia as duas grandes concepções que atravessam as práticas e os discursos sobre Educação para os meios, uma mais pedagógica e linguística e outra mais política e civil.

Outro pesquisador que se destaca é o britânico David Buckingham ${ }^{6}$ (2006), na reflexão sobre as perspectivas crítica, metodológica - instrumental e produtiva-expressiva que envolvem o trabalho com a Midiaeducação, os novos meios são usados, contemporaneamente, como objeto de estudo e como meio de aprendizagem e as dimensões críticas e criativas são fortemente integradas. Quanto à Media Literacy nos EUA, Soares (2014, p. 16) relata que houve várias oscilações marcadas, sobretudo, pelo período político. Grosso modo, nos momentos em que os republicanos encontravam-se no governo, era visível o pouco apoio dado à questão, ao contrário do que ocorria quando os democratas estavam na Casa Branca.

Prova disto, no final do primeiro mandato do democrata Bill Clinton, em 1995, a Media Literacy, que, até então, estava presente em programas educativos de apenas 12 estados, foi inserida nos parâmetros curriculares (academic standarts) de todos os estados federados do país (SOARES, 2014). A construção histórica da Media Literacy pode ser dividida em três momentos ou fases relevantes: na primeira, a questão moralista e defensiva de protecionismo aos efeitos dos meios de comunicação prevaleceu, nos anos 1970, chamada de deficit model. Neste período, Adilson Citelli (2014, p. 66) destaca que o problema residia em "manter a vigilância sobre os mediadores de imaginários, símbolos, representações, a fim de que não ajudassem a promover desvios destoantes pelo American way of life - 'o modo de vida americano".

6 Os estudos culturais foram aplicados no campo da Media Literacy por autores britânicos como David Buckingham (Watching media learning, 1990). 
Nos anos 1980, o movimento de leitura crítica da mídia, sob a luz deste pensamento, perdeu importância, e na década de 1990, com a disseminação do vídeo e o advento da internet, houve um novo fôlego para as análises dos meios de comunicação como prática educativa, aliada à reforma educacional americana. $\mathrm{O}$ enfoque passou a ser a aquisição das habilidades (acquisition model), e o plano era fornecer uma plataforma de questões que possibilitassem aos estudantes elaboração de habilidades na área da Comunicação e Expressão. Identificou-se também uma terceira tendência - Citizenship model, que surgiu quando os objetivos dos educadores e educandos passaram além da leitura crítica da mídia para o pensar das relações de Comunicação entre os sujeitos sociais (SOARES, 2014).

A partir dos anos 2000, um grupo de arte-educadores da Costa Oeste americana começou a trabalhar o conceito de multiculturalismo com adolescentes negros, brancos e latinos por intermédio da linguagem visual - o que aproxima à ideia de Educomunicação, na perspectiva do NCE/USP a ser tratada a seguir.

\section{Da Herança Latino-americana à Educomunicação: uma história em construção}

Mario Kaplún é responsável pela criação e uso do termo educomunicador para designar o professor que realiza a "Comunicação Educativa". No entanto, este autor nunca se preocupou em identificar ou definir a existência de um campo denominado "Educomunicação". Na década de 1980, a Unesco usou o termo "Educomunicação", mas no sentido de leitura crítica das mídias. Coube ao NCE/USP, em 1999, identificar e definir o conceito de Educomunicação como referente a um campo autônomo de pesquisa e intervenção social, por meio de uma pesquisa coordenada pelo professor Dr. Ismar de Oliveira Soares. Na perspectiva do NCE/USP, o conceito é resultado de extensa pesquisa entre 1997-1999, envolvendo 176 coordenadores especialistas da área em 12 países do continente.

A partir da análise qualitativa desta investigação, o NCE concluiu que não havia mais lógica em compreender a relação entre Comunicação e Educação, a partir das atribuições, até então, feitas a elas, como o emprego didático das Tecnologias de Informação e Comunicação (TICs) ou como leitura crítica dos conteúdos midiáticos. 
Dessa maneira, a educomunicação não pode ser vista como item programático a ser tratado no território restrito da didática ou como mera capacitação para ajudar na aplicação das tecnologias da informação ou comunicação ao ensino, mas como um campo de reflexão e intervenção social decorrente dos novos modos de organizar, distribuir e receber o conhecimento e a informação (CITELLI, 2014, p. 70).

Dito de outra maneira, o que esta primeira década do século XXI trouxe à Educomunicação foi o reconhecimento acadêmico, graças à pesquisa do NCE/USP que passou a compreender que as ações do movimento popular, no tocante à interface Comunicação e Educação, resultaram de uma opção teórico-metodológica que se distanciava das perspectivas tecnicistas, conteudistas ou funcionalistas (SOARES, 2014).

Neste aspecto, o coordenador do NCE/USP, Ismar Soares de Oliveira (2002, p. 5), define a Educomunicação como

o conjunto das ações inerentes ao planejamento, implementação e avaliação de processos, programas e produtos destinados a criar e fortalecer ecossistemas comunicativos em espaços educativos presenciais ou virtuais, assim como melhorar o coeficiente comunicativo das ações educativas, incluindo as relacionadas com o uso dos recursos da informação nos processos de aprendizagem.

Soares esclarece que espaços educativos podem ser considerados os centros culturais, emissoras de televisão, rádios educativas, centros de produção de materiais, sem desconsiderar os espaços não formais. Ao tratar de ecossistema comunicativo, refere-se desde a organização do ambiente, incluindo a disponibilização de recursos, bem como a maneira de atuar dos sujeitos envolvidos, e o conjunto de ações que definem um tipo de fato comunicacional.

Dando sequência, apresentaremos um breve resumo da história da Educação para a Comunicação na América Latina, especialmente no Brasil, marcada por inúmeros projetos, desde a década de 1960 até os dias atuais. Compreende-se que a leitura destes acontecimentos e desdobramentos corroboram para o entendimento do processo histórico da Educomunicação.

Historicamente, nas décadas de 1960 e 1970, em nosso continente, as discussões em torno de projetos educativos para a Comunicação estavam atreladas à educação não formal, particularmente aos movimentos populares, que, em sua maioria, mostravam-se resistente às políticas de comunicação implantadas por governos ditatoriais.

Entre os destaques desta fase, o Programa de Educação Alternativa para a Formação do Receptor a partir da Infância (PLAN-DENI) que tinha como 
principal objetivo oportunizar aos alunos, principalmente de denominação católica, de vários países da América Latina, uma formação crítica à recepção.

Em 1970, concomitantemente, de uma lado, intelectuais defendiam a difusão da "leitura crítica da televisão" como caminho para a consciência crítica; enquanto que de outro, pensadores latino-americanos manifestavam fortes reações à influência dos meios comunicacionais, especialmente da TV.

Nessa década, as ideias de participação, de diálogos social e planejamento participativo, marcaram o pensamento latino-americano, influenciadas pela concepção dialógica e libertária do educador brasileiro Paulo Freire e de outras referências da área, como: Juan Diaz Bordenave (Paraguai), Mario Kaplún (Uruguai), Daniel Pietro (Argentina) e Eduardo Contreras (Equador). Neste processo, uma das instituições mais importantes foi o Centro Internacional de Estudios Superiores de Comunicación para América Latina (Ciespal), com sede em Quito, Equador.

Conforme já citado, dos anos 1980 aos 1990, a Unesco teve função articuladora, com vistas à aproximação da Comunicação e Educação, na esfera das políticas públicas. Fato comprovado em 1979, quando este órgão organizou um encontro no México, reunindo os ministros da Educação e Planejamento da América Latina e Caribe. Constatou-se, então, que os educadores para os meios, gradativamente, abandonaram as teorias da Escola de Frankfurt e as questões ideológicas do estado, com base na proposta de uma Nova Ordem Mundial da Informação e Comunicação (NOMIC).

Neste continente, a década de 1990 foi marcada pela influência dos Estudos Culturais (EC) ingleses, os projetos envolvendo a Educação para os meios eram direcionados ou na tendência da proposta dos americanos ou dos europeus.

Em outra linha de pensamento, especialistas latinos reforçaram a abordagem de grupos que se preocupavam com os processos comunicativos em sobreposição aos meios. Resgatamos Raymond Williams (1992, p. 41-43), que apresentou a cultura como um processo sócio-histórico que cria e assimila sentidos.

A partir de então, um novo paradigma na interface Comunicação e Educação passava a ser assumido com direcionamento à cidadania, o coletivo, chegando à Educomunicação.

O conceito de educomunicação adotado ao final da pesquisa da USP passou a traduzir a desejada autonomia de uma prática não exatamente à margem dos tradicionais campos de comunicação e da educação, mas justamente em sua interface, às vezes com eles se confrontando e, em outras, com eles colaborando (SOARES, 2014, p. 185). 
Enfim, após breve descrição histórica, sob a luz dos conceitos da Educomunicação e da Midiaeducação, exemplificaremos, brevemente, a seguir, ações de governo direcionadas aos trabalhos pedagógicos com estes dois paradigmas nos municípios de São Paulo e Rio de Janeiro.

\section{Políticas Públicas e Educação Midiática: os exemplos de São Paulo e Rio de Janeiro}

No Brasil, os municípios de São Paulo e Rio de Janeiro possuem ações institucionalizadas em suas redes educacionais, baseadas nos paradigmas da Educomunicação (SP) e Midiaeducação (RJ) há mais de uma década. Fato que corroborou para o desenvolvimento de nossa pesquisa, já que nosso objeto empírico constitui-se do conjunto dos elementos que, nos respectivos contextos, definem as políticas públicas de Educação Midiática nas duas cidades. Contudo, é importante considerar que

cada conceito carrega seus referenciais e metodologias, mas os atendidos - os alunos são indistintamente beneficiados. O grande diferencial está na meta de cada prática: uma trabalha para que a criança e o adolescente sejam capazes de produzir conhecimentos a respeito de suas relações com a mídia e de usufruir de seu potencial inovador, dominando processos produtivos; já a outra tem como meta transformar a comunidade educativa num ecossistema comunicativo aberto, dialógico e participativo (SOARES, 2014, p. 22).

Com a reflexão de Ismar de Oliveira Soares, coordenador do Núcleo de Comunicação e Educação (NCE), lembramos que o ano de 1996, ano de criação do Núcleo na Escola de Comunicações e Artes da Universidade de São Paulo (ECA/USP), foi um momento importante para a difusão do paradigma. Anos mais tarde, em 1999, ocorreu a grande pesquisa que ressemantizou o conceito de Educomunicação. No início dos anos 2000, ocorreram as primeiras iniciativas que envolveriam Políticas Públicas com a prática educomunicativa.

O projeto batizado de "Educom" contou com a participação de professores da ECA/USP e pesquisadores vinculados. Parte deste projeto tratavase do "Educom.rádio: Educomunicação nas ondas do rádio"

7 Para mais informações: ALVES, P. H. (2007) Educom. rádio: uma política pública em Educomunicação. Tese. ECA/USP. São Paulo, SP, Brasil. 
tantas pessoas e notoriedade que tornou-se lei em 28 de dezembro de 2004, de autoria do vereador Carlos Neder: Lei Municipal no 13.941.

Em 2009, a inclusão na legislação da Portaria no 5.792, da Secretaria Municipal de Educação de São Paulo, provocou avanços no processo de institucionalização da Educomunicação, pois estabeleceu diretrizes que possibilitaram a contratação de uma equipe de especialistas para realizar as formações dos docentes e o reconhecimento oficial dos projetos de Educomunicação desenvolvidos nas escolas municipais de São Paulo.

Atualmente, o projeto chamado "Nas ondas do rádio"8 conta com um Núcleo de Educomunicação, desde 2015, sob a responsabilidade de Carlos Lima, vinculado à Secretaria Municipal de Educação de São Paulo (SME). Os cursos de formação continuada ofertados são: gestão de projetos educomunicativos, agência de notícias, vídeo, blog, fotografia, audiovisual, fanzine, impresso, rádio, entre outros.

Entre os objetivos do programa, os ideais educomunicativos, na perspectiva do NCE/USP, promovem o protagonismo infantojuvenil por meio da comunicação e tecnologia; a cultura da paz no espaço escolar, o aperfeiçoamento das competências leitora, escritora e oral e possibilitam espaços de expressão comunicativa e criativa às crianças e adolescentes.

O município do Rio de Janeiro também trata do uso da mídia no ambiente escolar, sob o paradigma da Midieducação; para tanto, possui uma Gerência de Mídia-Educação sediada na Secretaria Municipal de Educação (SME) sob o comando de Simone Monteiro de Araújo. A SME conta com o apoio da MultiRio (Empresa Municipal de Multimeios Ltda), órgão criado pela Lei no 2.029 e idealizado pela ex-secretária municipal do Rio de Janeiro, Regina de Assis, e por Walter Clark, na época, presidente da TV Educativa (TVE), que também atuou na criação das Empresas Globo de Televisão. Em 1996, a então secretária municipal de Educação, Regina de Assis, implementou o Núcleo Curricular Básico Multieducação, inserindo a questão das linguagens e da diversidade tecnológica na sala de aula.

Disponível em: <http://www.teses.usp.br/teses/disponiveis/27/27154/tde-05072009-211722/ pt-br.php>. Acesso em 30 mai. 2015.

E MESSIAS, C. (2012) Duas décadas de Educomunicação: da crítica ao espetáculo. Dissertação, ECA/USP, São Paulo, SP, Brasil. Disponível em: <http://www.teses.usp.br/teses/ disponiveis/27/27154/tde-24032012-102952/pt-br.phps> . Acesso em 30 mai. 2015.

8 Disponível em <http://portal.sme.prefeitura.sp.gov.br/Main/Page/PortalSMESP/Nas-Ondas-do-Radio>. Acesso em 30 mai. 2015. 
Eventos importantes acerca da Midiaeducação foram realizados no Rio de Janeiro pela MultiRio; o mais importante foi a 4 a Cúpula Mundial de Mídia para Crianças e Adolescentes, um dos maiores eventos internacionais da época.

Hoje, a MultiRio possui um aparato tecnológico e de profissionais (aproximadamente 170 pessoas) das áreas da Comunicação e Educação voltado, em sua maioria, ao trabalho, sobretudo com a linguagem audiovisual. Conta com estúdios próprios para elaboração dos programas distribuídos na rede educacional e formação continuada de professores e alunos. A atual presidente da MultiRio, Cleide Ramos 9 atuou de 1995 a 2000 e retornou em 2009, até o presente momento $\mathrm{Na}$ época da fundação, Cleide Ramos era diretora de tecnologia e educação da TVE, quando trabalhou com Walter Clark, utilizando todas as mídias para elaboração de conteúdos educativos.

Segundo Simone Monteiro, desde 2009, com a nova gestão política, e em 2011, com reformulações na própria SME da prefeitura do Rio de Janeiro, apesar da independência da MultiRio, existe um maior direcionamento das diretrizes teórica e de práticas midiaeducativas pela SME. Prova disto é a pesquisa em andamento, desde o início de 2015, do Grupo de Pesquisa, Educação e Mídia (GRUPEM) do Programa de Pós-Graduação em Educação da PUC-Rio, sob a coordenação da professora Rosália Duarte, financiada pelo Instituto Desiderata e feita em parceria com a Gerência de Mídia-Educação da SME. A pesquisa é intitulada Projetos de mídia-educação nas escolas da Rede Pública Municipal do Rio de Janeiro e aprendizagem escolar.

\section{Conclusão}

Ainda não é possível extrair qualquer conclusão; afinal, a pesquisa doutoral encontra-se em vias de qualificação e continuará em desenvolvimento. Por isto, é muito cedo para qualquer definição. Contudo, observamos que é a partir da década de 1980 que ocorre a inserção da educação midiática em ações governamentais, sem contar que houve grandes incentivos da Unesco, prova disto é a Declaração de Grünwald (Alemanha), de 1982, que contou com 19 países participantes, cuja ênfase é sobre a importância das

9 Cleide Ramos cedeu entrevista à autora deste artigo no Rio de Janeiro, em setembro de 2014, por conta da referida tese de doutorado. 
mídias e a obrigação de os sistemas educacionais auxiliarem os cidadãos a compreender melhor este fenômeno.

Como observado, historicamente, as redes municipais de ensino de São Paulo e Rio de Janeiro iniciaram as práticas pedagógicas com a educação midiática entre o início da década de 1990 e os anos 2000. E, nestes períodos, acabaram criando as Políticas Públicas na área por meio de rotas diferenciadas, influenciadas pelas marcas herdadas do paradigma latino-americano da Educomunicação na capital paulista e da tradição europeia da Media Education no Rio de Janeiro. Entretanto, é notável que as ações pedagógicas com a Comunicação são anteriores, nos referidos sistemas de ensino municipais, ao surgimento de Políticas Públicas e que, particularmente, no contexto da época, a questão das inovações tecnológicas influenciaram muito essas decisões nas duas redes.

Neste artigo, a nossa maior preocupação foi o respeito à história e fundamentação teórica-metodológica de cada paradigma. Neste aspecto, apesar das semelhanças, quando tratamos de Educomunicação e de Midiaeducação, há diferenças que ampliam e promovem debates, troca de ideias, para o aperfeiçoamento necessário no trato com o uso da mídia na Educação. A nossa intenção é demonstrar que essas duas práticas são perfeitamente passíveis de diálogos e compõem o grande "guarda-chuva” chamado Educação Midiática. O fato é que ainda iremos em busca de mais respostas para o nosso problema de pesquisa; afinal, o que aproxima ou diferencia as Políticas Públicas de Educação Midiática implantadas nas cidades de São Paulo e Rio de Janeiro? 


\section{Referências}

ALVES, P. H. Educom.rádio: uma política pública em Educomunicação. Tese. ECA/USP. São Paulo, 2007.

BACCEGA, M. A. A comunicação/educação e a construção de nova variável histórica. In: CITELLI, A; COSTA, M.C. Educomunicação, construindo uma nova área de conhecimento. São Paulo: Paulinas, 2011.

BUCKINGHAM, D. La media education nell'era della tecnologia digitale. Relazione per il Congreso del MED La sapienza di comunicare: Roma, 2006.

CITELLI, A. O; BERGER, C; BACCEGA, M. A; LOPES, M. I. V; FRANÇA, V. V. Dicionário de Comunicação: escolas, teorias e autores. São Paulo: Contexto, 2014 .

DI MELE, L. L’Europa verso la media literacy. Media education, studi, ricerche, buone pratiche. Roma, 2011.

FANTIN, M. Mídia-Educação: aspectos históricos e teóricos-metodológicos. Revista Olhar de professor. Ponta Grossa, 14(1): 27-40, 2011.

KAPLÚN, M. Una pedagogia de la comunicación. Madrid: Editorial de la Torre, 1998.

JACQUINOT, G. Dall'educazione ai media alle 'mediaculture': ci vogliono sempre degli inventori. Congresso del MED La sapienza do comunicare, Roma, 2006.

MARANHÃO, C. A. C. Quitongo, mídia e cidadania: a política de 'mídia e educação' da prefeitura do Rio de Janeiro em uma perspectiva discursiva e comunitária. Dissertação. FE/USP, São Paulo, 2007.

MARTÍN-BARBERO, J. Heredando el futuro. Pensar la educación desde la comunicación. Nómadas, Bogotá, n.5, p.10-22, 1997.

A comunicação na educação. São Paulo: Contexto, 2014.

Comunicación fin de siglo. Para donde vá nuestra investigación? Telos, 47, Madrid, 1996.

MESSIAS, C. Duas décadas de Educomunicação: da crítica ao espetáculo. Dissertação, ECA/USP, São Paulo, 2012. 
SOARES, I. O. Comunicação/Educação: a emergência de um novo campo e o perfil de seus profissionais. Revista Brasileira de Comunicação, Arte e Educação, $n^{\circ} \cdot 7$. Brasília, 1998.

SOARES, Ismar de Oliveira. Do Santo Ofício à Libertação. São Paulo:Paulinas, 1988.

SOAR ES, Ismar de Oliveira. Gestão Comunicativa e Educação: Caminhos da Educomunicação. Revista Comunicação e Educação. Número 23. 16 a 25. Jan./ Abr.2002.

Educomunicação: as múltiplas tradições de um campo emergente de intervenção social na Europa, Estados Unidos e América Latina. In: LIMA, J. C. G.; MARQUES DE MELO, J. (Orgs). Panorama da Comunicação e das Telecomunicações no Brasil 2012-2013. Memória, Brasília, IPEA, vol. 4, pg. 169-202, 2013.

. Educomunicação e Educação Midiática: vertentes históricas de aproximação entre Comunicação e Educação. Revista Comunicação e Educação. Ano XIX. Número 2.Jul-Dez 2014.

THOMPSON, J. B. A Mídia e a Modernidade: uma teoria social da mídia. Rio de Janeiro: Petrópolis, 2011.

VELLOSO, L. Luz, Câmera, [Multieduc] Ação! Práticas docentes, políticas curriculares e as TIC's na rede municipal do Rio de Janeiro. Dissertação. UERJ, Rio de Janeiro, 2010.

WILLIAMS, R. Cultura. Rio de Janeiro: Paz e Terra, 1992.

WILSON, C. et al. Alfabetização midiática e informacional: currículo para a formação de professores. Brasília: UNESCO, UFTM, 2013. 


\title{
Educomunicação e transmidiação: considerações sobre audiência, protagonismo e ressignificações ${ }^{1}$
}

\author{
Cláudio Messias ${ }^{2}$ \\ Universidade Federal de Campina Grande, Paraíba, PB \\ NCE/ECA/USP, São Paulo, SP
}

\section{Introdução}

O conceito de educomunicação, surgido a partir de estudos fincados na Escola de Comunicações e Artes da Universidade de São Paulo e difundido nas plataformas de interação de pesquisas de organizações como a Intercom³, tem ganhado vertentes multiplicadoras de acepções acerca de sua definição primeira. Decorridas duas décadas desde as reflexões preliminares que, observadas principalmente nos movimentos sociais, no berço da educação não formal, consideraram as relações diretas entre (i) "quem educa e quem aprende" e, nesse ínterim, numa primeira via, (ii) "quem educa, educa o quê, para quê e para quem?" e, em via secundária, de retorno, "quem aprende, aprende o quê, de que maneira, para quê e, principalmente, através de quem?" Agora, os pressupostos epistemológicos do campo da inter-relação comunicação/educação começam a ser apreendidos por estudos alheios, dentro e fora do Brasil.

1 Trabalho inscrito no GP Comunicação e Educação do XX Encontro de Pesquisa em Comunicação e Educação, evento componente do XXXVIII Congresso Brasileiro de Ciências da Comunicação, Rio de Janeiro, 2015.

2 Docente no curso de Comunicação Social-Educomunicação da Unidade Acadêmica de Arte e Mídia, na Universidade Federal de Campina Grande (UFCG), Paraíba; doutorando em Ciências da Comunicação na Escola de Comunicação e Artes da Universidade de São Paulo (ECA/USP). Pesquisador vinculado ao Núcleo de Comunicação e Educação da Universidade de São Paulo (NCE/USP).E-mail: clmessias@usp.br

3 Sociedade Brasileira de Estudos Interdisciplinares da Educação. 
Parto desse exposto considerando os dados quantitativos de pesquisa que desenvolvi, em nível de mestrado, no PPGCOM/ECA/USP4 (MESSIAS, 2010), com base em papers inscritos nos congressos nacionais anuais da Intercom e da ANPed5, assim como em teses e dissertações defendidas na Universidade de São Paulo. Ambos os casos com autores justificando suas práticas de pesquisa como atreladas à inter-relação comunicação/educação. Em uma nova etapa de pesquisa, em doutoramento, aproveitei as análises documentais feitas no mestrado, em especial no tocante às referências bibliográficas utilizadas por autores de papers de congressos, dissertações e teses.

Foi com essa premissa que avultei, durante a trajetória desse estudo, a proposta de coleta de dados apresentada em projeto. O motivo é a oportunidade surgida de cursar a disciplina condensada Teorias para convergência de televisão e mídia digital e metodologias de entrevista de história de vida com tecnologias de mídia, ministrada no segundo semestre letivo de 2014 pelo Prof. Dr. Joseph Straubhaar, da Universidade do Texas, em Austin, EUA, convidado pelo PPGCOM/ECA/USP. Straubhaar é um dos autores mais citados principalmente em papers de congressos como os da Intercom e da ANPed, por seu repertório de publicações que contempla o fenômeno da mediação tecnológica na educação. O professor norte-americano é, também, parte das referências teóricas que utilizei no mestrado, interesse de pesquisa, esse, despertado pelo fato de, em seu currículo na Universidade do Texas, constar investigações desenvolvidas desde os anos 1970 contemplando a realidade socioeconômica da América Latina, em especial o Brasil, no que se refere a comportamento de consumo de mídias.

Minhas interações de roteirização de pesquisa com Straubhaar ocorreram de maneira a conceber, inicialmente, que a transmidiação - , advinda da acepção de Jenkins (2009) por transmedia storylling, seja uma tendência que, embora nova nos parâmetros da inter-relação comunicação/ educação, percebe uma audiência que, com certa assiduidade de consumo perante determinado conteúdo/fenômeno midiático, busca criar as próprias histórias e antecipar os desenlaces do roteiro original. Daí, pois, o propósito de levantar, com aquela coleta de dados, a influência da mediação tecnológica na constituição da história de vida de gerações diversas, e não somente

\footnotetext{
4 Programa de Pós-Graduação em Ciências da Comunicação da Escola de Comunicações e Artes da Universidade de São Paulo.

5 Associação Nacional de Pós-Graduação e Pesquisa em Educação.
} 
de jovens como costumam contemplar as investigações cujos objetos são por seus autores atribuídos à educomunicação.

O título da pesquisa com Straubhaar foi definido, em comum acordo com o pesquisador norte-americano, como Práticas de transmídia na transição da tecnologia analógica para a digital: um olhar sobre a maneira como gerações diferentes construíram suas histórias de vida com a tecnologia no Brasil. Nas análises, percebi um perfil de consumidor mediático contemporâneo muito próximo dos sujeitos sociais os quais a educomunicação se propõe a, mediante articulações de gestão de processos sociais, ajudar a formar, pela vertente de área de intervenção social (SOARES, 2011), e a conscientizar, na perspectiva dos processos de linguagem (OROZCO GÓMEZ, 2014).

A oportunidade de cursar aquela disciplina condensada, somada à expectativa de interagir diretamente com um teórico da inter-relação comunicação/educação vindo dos EUA, o berço da media education enquanto estudo sobre o impacto dos meios de comunicação de massa (SILVERSTONE, 1992) e da media literacy porquanto parte das políticas públicas norte-americanas e como estratégia de conscientização para o consumo midiático (HOBBS, 2010 $)^{6}$, permitiu um diálogo estreito, informal, acerca da acepção de Straubhaar sobre o conceito de educomunicação. Esse tipo de interação, segundo a própria metodologia de análise dialógica (SPRADLEY, 1979) recomendada pelo professor norte-americano, considera que um determinado fenômeno social, mediante análise qualitativa, possa ser investigado em comunidades cujos territórios sejam culturalmente diferentes, mas, sobretudo, mediante um olhar comum que considere a escola, como é o caso do cerne dessa investigação, um ecossistema de característica urbana universalmente concebida. Straubhaar, outrossim, centraliza seu discurso na mediação tecnológica que envolva relações de ensino-aprendizagem e novas formas de empoderamento da audiência mediante uso das mídias digitais, observando o avançar epistemológico da educomunicação com a postura de quem vivenciou, nos EUA, a vigência dos estudos de media education e media literacy, e testemunhou, na América Latina, as reflexões que dão escopo teórico à Escola Crítica Latino-americana de Comunicação.

6 HOBBS, Renee (2010). "Empowerment and protection: Complementary strategies for digital and media literacy in the United States". Disponível em http://works.bepress.com/ reneehobbs/11/. Acesso em 29/JAN/2016. 
Straubhaar, em sua bibliografia e no discurso docente que adota em suas aulas, adverte para alguns exageros relacionados a conclusões acerca da incorporação das mídias nos processos da educação formal. Aquele pesquisador não contesta que as discussões que desencadearam os estudos iniciados por Ismar de Oliveira Soares, na ECA/USP, na década de 1990, tenham sido norteadas por correntes de um pensamento latino-americano prevalente, historicamente, na contramão dos estudos de recepção que a essa parte do continente chegavam advindos da Europa e dos Estados Unidos. Ele cita, a esse respeito, o que Fadul (1993) já advertia para um suposto equívoco nas formas de analisar a Indústria Cultural e suas conflituosas relações ora com a escola, ora com a relação direta com outro conceito, o da Escola de Frankfurt.

Habituou-se, logo, na forma de entendimento de Straubhaar, a demonizar as interações da audiência com os veículos de comunicação de massa, desconsiderando-se o desdobramento de vivência dos teóricos que deram base a essa postura, quais sejam Adorno e Horkheimer, cujas trajetórias, na fundação do conceito de Indústria Cultural, precisam, segundo Fadul (1933), considerar as fases em que ambos, judeus, juntos fogem da Alemanha nazista, estabelecem-se nos Estados Unidos, refletem as relações de consumo mediante decepções acerca da sociedade norte-americana e, depois, antes de morrerem, reveem os próprios conceitos a partir de uma ressignificação das vivências. A esse respeito a autora destaca que

é preciso, portanto, interpretar o conceito de Indústria Cultural a partir do seu contexto histórico. De um lado, o nazismo; de outro, a sociedade americana vista pelos filósofos judeus emigrados como o sintoma da decadência cultural do Ocidente. A partir das ideias do livro Indústria Cultural e Cultura de Massa, tentou-se definir uma indústria muito especial, que produz não uma mercadoria qualquer, mas sim uma mercadoria [...]. Os pontos de partida das teorias desenvolvidas pelos dois autores mencionados são o Marxismo e a Psicanálise. Mas é comum designá-los como pertencentes - ao lado de outros filósofos, sociólogos, psicanalistas e historiadores - à Escola de Frankfurt, que na verdade nunca existiu, mas sim o Instituto de Pesquisas Sociais da Universidade de Frankfurt. Assim, cada vez que se fizer uma denúncia em relação à Indústria Cultural, corre-se sempre o risco de ser chamado de "frankfurtiano". Se não existiu, na verdade, a Escola de Frankfurt, existiu sim uma certa coerência teórica entre aqueles que denunciavam a sociedade de massa, como a suprema forma de totalitarismo e de perversão da cultura (FADUL, 1993, p. 55-56).

É nesse aspecto que Straubhaar defende que as histórias de vida, por representarem narrativas de diversos "eus" individualizados, não podem 
ser confundidas com o consenso coletivo sobre determinado fenômeno, por exemplo, midiático, cabendo ao pesquisador compreender que a análise em voga pode não incorrer na comum relação com a persuasão hegemônica do mercado. Nem todo tipo de comportamento da audiência, nesse ínterim, advém de direcionamento doutrinador preestabelecido. Nesse prisma, em oportunidade anterior, no ano de 2013, publicando artigo na revista Matrizes, do PPGCOM/ECA/USP, o pesquisador norte-americano já advertia para uma situação em que o movimento da vida local tradicional, quando deslocado para a interação moderna com as mídias de massa, produziu identidades compostas por camadas que, múltiplas, têm elementos geográficos que são locais, regionais e transnacionais, na perspectiva de globalização, mas não necessariamente resultantes de uma nova forma de cultura, híbrida, determinada pelo consumo. O autor afirma, em primeira pessoa, que:

eu articulo isso [a hibridização cultural] como um processo duplo. Como um observador no Brasil ou Texas, por exemplo, noto uma hibridização cultural acontecendo em uma variedade de situações e (sub) culturas [...]. Tanto no Brasil quanto no Texas encontro pessoas que articulam claramente uma noção local de si, uma noção regional de si, uma noção nacional de si, algum interesse ou conhecimento do global, uma noção de si de classe social, uma noção de si religiosa, uma noção de si étnica e/ou linguística, uma noção de si educacional ou profissional (STRAUBHAAR, 2013, p. 61).

O poder persuasivo das mídias, vejo, a partir das postulações de Straubhaar, é apropriado por parte dos pesquisadores, nos primórdios da constituição do conceito de educomunicação, a partir de um viés comum, carecido de maturação, que remete a tudo de negativo advindo dos conteúdos produzidos pelos veículos massivos de comunicação. A sociedade de massa, nesse ínterim, é objeto da modernidade, mas cabe ressaltar que, nessa vertente, essa produz modos de vida que desvencilham, de acordo com Giddens (1990), os sujeitos de todos os tipos tradicionais de ordem social, e de uma maneira, conforme aponta o autor, sem precedentes. Giddens (1990) cita a intencionalidade e a extensionalidade como fatores marcantes na transformação implicada pela modernidade, mais profunda que a maioria dos tipos de mudança característicos dos períodos precedentes. O autor explana, a esse respeito, que

sobre o plano extensional, elas serviram para estabelecer formas de interconexão social que cobrem o globo; em termos intensionais, elas vieram a alterar algumas das mais íntimas e pessoais características de 
nossa existência cotidiana. Existem, obviamente, continuidades entre o tradicional e o moderno, e nem um nem outro formam um todo à parte $[. .$.$] . Mas, as mudanças ocorridas durante os últimos três ou quatro$ séculos - um diminuto período de tempo histórico - foram tão dramáticas e tão abrangentes em seu impacto que dispomos apenas de ajuda limitada de nosso conhecimento de períodos precedentes de transição na tentativa de interpretá-las (GIDDENS, 1990, p. 14).

Igual a Straubhaar (2013) e apontando a globalização como fator marcante na característica da sociedade moderna, ora tida como pós-moderna, Giddens (1990) refere-se não a uma Indústria Cultural específica, mas a um industrialismo que, genérico, abarca todos os modos de produção, em especial aqueles tecnologicamente mediados. Tal movimento está, diz o autor, intrinsecamente ligado a um ciclo histórico relacionado ao poder controlador. Logo, no viés do capitalismo e sob a perspectiva de nações dominantes, se até 1990 a soberania pela força era bélico, militar, desde então o domínio da informação entra como elemento inovador para doutrinamento. O que está em voga, outrossim, é o impacto globalizante da mídia, em reflexão a uma publicação que Giddens (1990, p. 81), em tempo histórico, elabora no exato momento em que o planeta começa a sentir os impactos simbólicos e ideológicos do evento histórico simbolizado pela Queda do Muro de Berlim:

Um dos traços principais das implicações globalizantes do industrialismo é a difusão mundial das tecnologias de máquina. O impacto do industrialismo é claramente não limitado à esfera de produção, mas afeta muitos aspectos da vida cotidiana, bem como influencia o caráter genérico da interação humana com o meio ambiente material $[. .$.$] . A$ difusão do industrialismo criou "um mundo" num sentido mais negativo e ameaçador do que o que foi mencionado. Entretanto, o industrialismo também condicionou nossa própria sensação de viver "em um mundo". Pois um dos mais importantes efeitos do industrialismo foi a transformação das tecnologias da comunicação.

Algumas perversões, no sentido de mudança do estado normal, são cometidas, vejo, no plano inicial da constituição do conceito de educomunicação. Esse tempo histórico, mostrado na atualização dos dados de mestrado, é a década de 1990, e estamos mirando nas constatações feitas em estudos capitaneados por Soares (2011) acerca do perfil do educomunicador na América Latina, investigação que, desdobrada em estudos posteriores, é o cerne das discussões e tensões envolvendo o reconhecimento do campo da inter-relação comunicação/educação. O autor define três áreas como sendo próprias da educomunicação: educação para a comunicação, mediação tecnológica 
na educação e gestão da educação em espaços comunicativos. Mais tarde, quando já dialoga com políticas públicas, enquanto parte em contribuição, Soares (2011) expande essa práxis peculiar do sujeito social formado sob os preceitos do conceito, estabelecendo o agir educomunicativo como sendo: 1) área da educação para a comunicação; 2) expressão comunicativa através das artes; 3) mediação tecnológica na educação; 4) pedagogia da comunicação; 5) gestão da comunicação; e 6) reflexão epistemológica.

\section{Educar a quê, a quem?; para quê e para quem?}

$\mathrm{Na}$ pesquisa de mestrado e no território de debates dos congressos anuais da Intercom7 ${ }^{7}$, atestei as nuances a que o conceito de educomunicação é submetido quando, depois de constituído em arcabouço teórico e aplicado, na prática, sob os preceitos científicos, seus pesquisadores e adeptos epistemológicos o definem mediante discurso da ciência. Como parte de coleta de dados do mestrado, um questionário respondido por 42 pesquisadores vinculados ao GP Comunicação e Educação da Intercom mostrou as definições comuns atribuídas ao agir educomunicativo. São elas:

- Educação para os meios

- Reflexão crítica dos meios

- Inter-relação Comunicação e Educação

- Inter-relação Educação e Comunicação

- Uso das interfaces comuns entre Comunicação e Educação

- Área de intervenção social

Vê-se, pois, que há uma definição em comum entre o que Soares preconizava em 2002, o que foi ampliado pelo próprio autor em $2010^{8}$ e o que parte dos pesquisadores vinculados à Intercom concebia até 2009, ano em que a coleta de dados do mestrado findou. Educar para os meios, logo,

7 Trabalho apresentado no XXXII Congresso Brasileiro, em Caxias do Sul, RS.

8 SOARES, Ismar de Oliveira. Educomunicação: o conceito, o profissional, a aplicação. São Paulo: Paulinas, 2010. 
faria parte do focus ${ }^{9}$ do educomunicador na distinta separação entre base e superestrutura a que se refere Williams (2005). Transitamos, é visível, de abordagens a despeito de fatos sociais, históricos, para uma especificidade dos estudos culturais. Não necessariamente uma abordagem ontológica de cultura, mas, como aprofundaremos em abordagem mais adiante nesse texto, a premissa de que a existência social determina a consciência em detrimento do que uma base determinante pode ter de relação com uma superestrutura determinada. Eis uma abordagem moderna de teoria da cultura que, marxista, semeia o vasto - e fértil - campo de discussões acerca da constituição epistemológica da educomunicação, uma área do conhecimento que nasce na contra-hegemonia e, entendo, (sobre)vive na hegemonia.

Educar para os meios ou educar para a comunicação, outrossim, são ações inerentes à prática educomunicativa, conforme Soares (2010, p. 36) definida como

o conjunto das ações voltadas ao planejamento e implementação de práticas destinadas a criar e desenvolver ecossistemas comunicativos abertos e criativos em espaços educativos, garantindo, desta forma, crescentes possibilidades de expressão a todos os membros das comunidades educativas.

Fica a dúvida, destacada em trabalho de nossa autoria, exposto no XXXIII Congresso Brasileiro da Intercom, sobre a práxis de quem educa para os meios ou para a comunicação. Com a necessária distinção entre o sujeito social educomunicador e o sujeito social educomunicólogo. Daí, pois, a indagação sobre “quem educa quem?” quando a questão está relacionada a um hipotético letramento midiático.

Logo, aquele que educa educandos estaria no focus do pesquisador do novo campo enquanto pré-preparado para tal finalidade ou necessariamente,

9 Designação que esse pesquisador adota para separar objeto pesquisado de fenômeno pesquisado, remetendo, etimologicamente, à origem da palavra focus, do latim, que por sua vez advém de uma substituição, no passado, à derivação ignis, do hindo-europeu, que significava "fogo". Logo, metodologicamente, um fenômeno pesquisado, especialmente em Comunicação, campo ainda incompleto da ciência, carece de ser separado em duas conjunturas: fumaça e fogo. Quando, pois, de uma etapa preliminar de estudos, em fase de pré-projeto, é passível de se compreender os rodeios em torno do objeto, ou seja, metaforicamente, vislumbrar fumaça; mas, no avançar da pesquisa, em especial, no alcançar da episteme do fenômeno, o pesquisador, afora o senso comum, carece de materializar o fogo, seu objeto. 
como mostra a construção sócio-histórica do fenômeno, continuaria em terreno onde prevalecem as complexas variações de constituição do saber, seja ela formal ou vulgar? A essa dúvida, Williams (2005) corrobora a separação entre base - centrada na essência existencial do homem - e superestrutura, que seria um reflexo, em imitação, das ações da base, de modo que o educomunicador cuja prática advém dos movimentos sociais, da liberdade do território de nascença do conceito, seja basilar, enquanto aqueles que o observam e dessa vivência (re)produzem conhecimento científico nada mais representem do que desmembramentos de superestrutura. Nesse contexto, segundo o autor,

"a base" é um modo de produção num estágio particular de seu desenvolvimento. Nós elaboramos e repetimos proposições desse tipo, mas na prática elas são muito diferentes da ênfase que Marx dedica às atividades produtivas, em particular nas relações estruturais, que constituem o fundamento de todas as outras atividades. Porque, se um estágio particular de desenvolvimento da produção pode ser descoberto e especificado pela análise, ele nunca é, na prática, uniforme ou estático. Esta é, de fato, uma das proposições centrais do sentido da História para Marx: a de que existem contradições profundas nas relações de produção e nas consequentes relações sociais (WILLIANS, 2005, p.213).

É necessário, pois, agregar nessa discussão outra abordagem sobre cultura, dessa vez de massa, presente em Morin (1984). Para o autor, o sujeito social tido como audiência pelos estudos de recepção transita por um universo imaginário da cultura midiática que dá sim vida aos personagens de ficção, mas que, quando do cotidiano objetivo, é separada da realidade. Setton (2010) adverte que, nesse contexto, as reflexões de Morin (1984) são extremamente pertinentes quando do situar epistêmico acerca de uma cultura mediática que precisa ser compreendida tanto por quem pesquisa comunicação como por aqueles que investigam a educação. A autora, por conseguinte, acrescenta que

é preciso estar atento também para a existência de uma zona na qual a distinção entre a cultura letrada e a cultura de massa se torna puramente formal [...]. Essa democratização da cultura cultivada é efetivamente uma das correntes da cultura de massa, mas não é a principal (SETTON, 2010, p. 63).

A posição de Morin (1984), ratificada por Setton (2010), remete ao que Fadul (1993) apontou, em trecho supracitado, como visão eventualmente equivocada sobre Indústria Cultural e suas consequências de letramento midiático no espaço da educação, seja ela formal, informal ou não-formal. Refletir 
criticamente sobre o poder persuasivo das mídias, elemento formativo da base da educomunicação, independeria, entre aqueles que aprendem, de intervenção de agente externo. A premissa dessa posição está em Williams (2005), confirmando as postulações de Straubhaar (2013), uma vez que a industrialização da cultura, enquanto modo concentrado de produção, nunca é estática ou uniforme. Jamais, outrossim, ignorando a necessária distinção entre encantamento e compreensão da realidade, uma vez que precisam, sim, ser consideradas as forças presentes nas mensagens midiáticas, mas, em contrapartida, igualmente considerar que a eficácia dessa dramatização da realidade está na superestrutura, enquanto a formação dos indivíduos advém da base.

Visualizar o local em que se encontra o sujeito social que constitui a audiência, como postula Straubhaar (2013), não pode ser reduzido, de acordo com Martín-Barbero (2008), como mera parte ou local do processo de comunicação. Receber os conteúdos produzidos pelos veículos de comunicação, pela cultura midiática, é um processo em constante mutação no prisma das investigações, e não cessa. Ratificando Beltrán e Cardona (1982), Martín-Barbero destaca a peculiaridade com que os estudos de recepção precisam ser compreendidos na América Latina e demais ex-colônias que passaram por processos de independência que historicamente, na construção de identidades nacionais, representaram mais do que rompimentos políticos, étnicos e econômicos em relação às ex-metrópoles. Há, pois, como aponta Setton (2010), uma lógica na interação das produções de conteúdos e na recepção das culturas das mídias. É esse o lugar em que se situa o focus da educomunicação, uma vez que prevalece a interação de sentidos com lutas e aceitações em vez de camuflagens, resistência ou transformação dos significados, ou, por conseguinte, de persuasão mediante ingenuidade primaz da parte que recebe.

\section{Práticas de transmidiação e a efetiva interação da audiência}

A pesquisa desenvolvida partiu da nossa inquietação quanto à disparidade na forma como a transformação da tecnologia analógica para a tecnologia digital impactou a vida de pessoas de diferentes gerações que, na contemporaneidade, convivem socialmente sob a hipotética persuasão para um consumo tecnologicamente mediado. São agentes que continuam assistindo a filmes nos cinemas e a conteúdos em aparelhos de televisão, mantêm o hábito de ouvir rádio ou ler jornais e revistas, em detrimento se tais costumes 
começaram mediante uso de uma ou outra plataforma tecnológica. Comportamentos de consumo midiático que se repetem desde o final do século XIX, mas que no século XXI ganham a novidade da interação, da audiência, diretamente na geração dos conteúdos produzidos.

Expectativas, pois, de estudiosos de hoje e de outrora do campo da comunicação são, em parte, atendidas. Não como ação direta, de intervenção, mas, em hipótese correspondente ao objeto dessa pesquisa, como processos de linguagem. Logo, a interação homem-tecnologia perpassa, nos dias atuais, por uma necessária alfabetização midiática, condicionada não só pelo domínio da tecnologia, mas principalmente da linguagem de relacionamento com pares no território simbólico, espacial, das plataformas digitais.

A inquietação que dá origem à investigação mirava, inicialmente, tão somente levantar um comparativo entre o que gerações que tinham entre 40 e 80 anos de idade no período da coleta de dados, qual seja, o segundo semestre de 2014, faziam para complementar o conteúdo informativo que ouviam no rádio ou assistiam na TV e no cinema, cruzando com o que aqueles que tinham menos de 40 anos de idade, na mesma época, procedem para saber assuntos de seu interesse. As interações com o pesquisador norte -americano e o contato com sua investigação acerca do comportamento das audiências, dentro e fora dos Estados Unidos, ampliaram, posso previamente concluir, tal inquietude.

Estou considerando, no aspecto dessa coleta de dados, que os quatro grupos de entrevistados submetidos, dentro da metodologia que considera narrativas em histórias de vida relacionadas ao consumo midiático, ao amplo questionário on-line ${ }^{10}$ são compostos por sujeitos sociais que vivenciaram períodos particulares, talvez díspares no contexto sócio-histórico, de relação de consumo dos conteúdos que preferiam e preferem na mídia. Parto, nesse ínterim, do pressuposto de que, caso sejam considerados os pensamentos comunicacionais norte-americanos, europeus e latino-americanos que incidiram nas oito décadas que representam o corte temporal, histórico, abarcado nessa pesquisa, seja possível supor um rompimento epistemológico, ou seja,

10 Os participantes foram convidados, através da rede social Facebook, a acessar o questionário na plataforma Google Docs durante as duas últimas semanas do mês de outubro de 2014. São pessoas que, com grau de amizade que considero "muito próximo", têm o mínimo de 19 e o máximo de 82 anos de idade e possuem, por suposição, posições sociais nas classes AB, C e D, além de se inserirem no contexto contemporâneo de uso das mais diversas mídias sociais. 
um novo paradigma no tocante à reconfiguração do papel da audiência. $\mathrm{Na}$ representação, essa, enquanto conjunto de receptores, cujo comportamento de aceitação ou negação a conteúdo altera sobremaneira a já não mais soberana e inabalável produção de mídias.

Inevitável, outrossim, cruzar conceitos construídos ao longo de quase um século abarcado pela pesquisa aqui elencada, a considerar que os entrevistados com idade mais avançada nasceram, no mínimo, nos anos 1930, no século passado. Não basta, entendo, lançar reflexão sobre os sujeitos sociais contemplados pela investigação em questão considerando-se somente o pressuposto, por exemplo, de nativos e imigrantes digitais (PRENSKY, 2005). Menos de meia década depois desse paradigma, concebo, os estudos de Orozco Gómez (2010) iriam além, apontando que para novas telas usadas em comum surgem novas educações. E isso, não necessária e exclusivamente no espaço da formalidade do território de ensino-aprendizagem da escola.

Tais fenômenos, observados em conjunto, apontavam para uma cultura de convergência que Jenkins (2009) destacou por compreendê-la como o uso cruzado das mídias e suas tecnologias, levando ao surgimento, nesse contexto, de uma cultura participativa e um redimensionamento do que Lévy (2003) postara anteriormente como inteligência coletiva, resultado, já então, de desdobramento para posterior conceito a partir da inteligência simbiótica, de Norman Lee Johnson ${ }^{11}$, e da sabedoria das massas, de James Surowieck ${ }^{12}$.

Falamos, logo, de uma audiência reconfigurada, que participa e tem sentido de pertencimento na relação com os veículos produtores dos conteúdos que consome. Há, nesse ínterim, uma interatividade constituída pelos mesmos patamares com que o receptor fora observado nas teorias de comunicação diversas, recentes. Lopes e Orozco Gómez (2014) assim estabelecem, ao olhar para o cenário da produção de ficção televisiva em países latino-americanos, da Ibero América e dos EUA, como sendo essa interatividade: passiva, ativa e criativa. Na interatividade passiva, definem os autores, o usuário de produtos midiáticos consome os conteúdos sem dar feedback, e a interação é apenas reativa quanto ao conteúdo. Já na interatividade ativa

11 Precursor das discussões acerca de inteligência coletiva nos anos 1970, é citado por autores como Pierre Lévy, justamente por entender a coletividade como construtora de conhecimento a partir de experiências compartilhadas.

12 Autor de A sabedoria das multidões (The Winston of Crowds), de 2004, que analisa as decisões coletivas como mais próximas da realidade, em comparativo com o resultado de análises individuais perante aos mesmos levantamentos. 
o usuário responde ao estímulo dado apenas dentro das próprias condições oferecidas pelo emissor, sendo propositiva ou crítica quanto ao conteúdo. A interatividade criativa, contudo, tem um usuário transformado em produtor de conteúdo, criando algo novo a partir daquilo que lhe foi dado (LOPES, 2013; OROZCO GÓMEZ, 2014). É a esse sujeito da audiência, aqui denominado de usuário da interatividade criativa, que este trabalho lança olhar, uma vez que, estimulado pelo produtor original dos conteúdos a emitir alguma resposta, produz conteúdo e, assim, transpõe sua condição de receptor e alcança o nível de produtor (LOPES, 2009).

\section{O perfil do praticante de transmídia: quatro gerações em estudo}

Apresento, a seguir, recortes do questionário aplicado em outubro de 2014, mediante utilização estratégica das redes sociais e acesso ao universo de entrevistados que, mediante abertura de suas histórias de vida na relação com as mídias, pertence a quatro gerações distintas. Foram convidados a participar usuários reconhecidamente praticantes de transmídia, mesmo sendo eles desconhecedores da atribuição científica às suas atividades de interação multiplataforma.

A análise preliminar, considerados os pressupostos discutidos com Straubhaar quando da roteirização da coleta de dados, aponta para a confirmação de que, independentemente da geração escolhida, os sujeitos sociais que figuram enquanto audiência nos multiprocessos comunicativos envolvendo mais de uma plataforma midiática comportam-se criticamente ante aos conteúdos que consomem. Sob os preceitos da interatividade, devolvem o referido comportamento de consumo; e, assim, percebidos pelo monitoramento permanente dos veículos de comunicação, alteram ou não roteiros e planejamentos da parte produtora das enunciações.

O questionário aplicado foi elaborado de maneira a especificar três das quatro vertentes que compõem o eixo central da investigação acerca da relação entre transmidiação e comportamento de consumo midiático coincidente com o conjunto de ações inerentes à episteme da educomunicação. Uma amostra do resultado da coleta de dados pode ser vista na Figura 1, sendo que a integralidade de todas as questões, com as respectivas respostas tabuladas em gráficos e tabelas, está disponibilizada na seção Anexos dessa pesquisa. 
FIGURA 1 - Perfil dos entrevistados na pesquisa Transmídia - Analógico/Digital

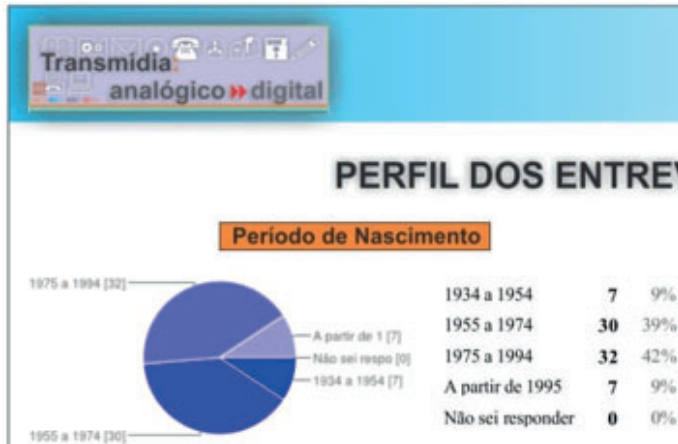

\section{Nivel de formaçăo (Estudos)}

Ensino Fundamental (Primário)

Ensino Médio (Segundo Grau)

Ensino Superior (Faculdade)

$1 \%$

Pós-graduaç̧̊o lato sensu (Especializaçâ, MBA, eté)

$37 \quad 49 \%$

～2 $\quad 3 \%$

Nåo sei responder

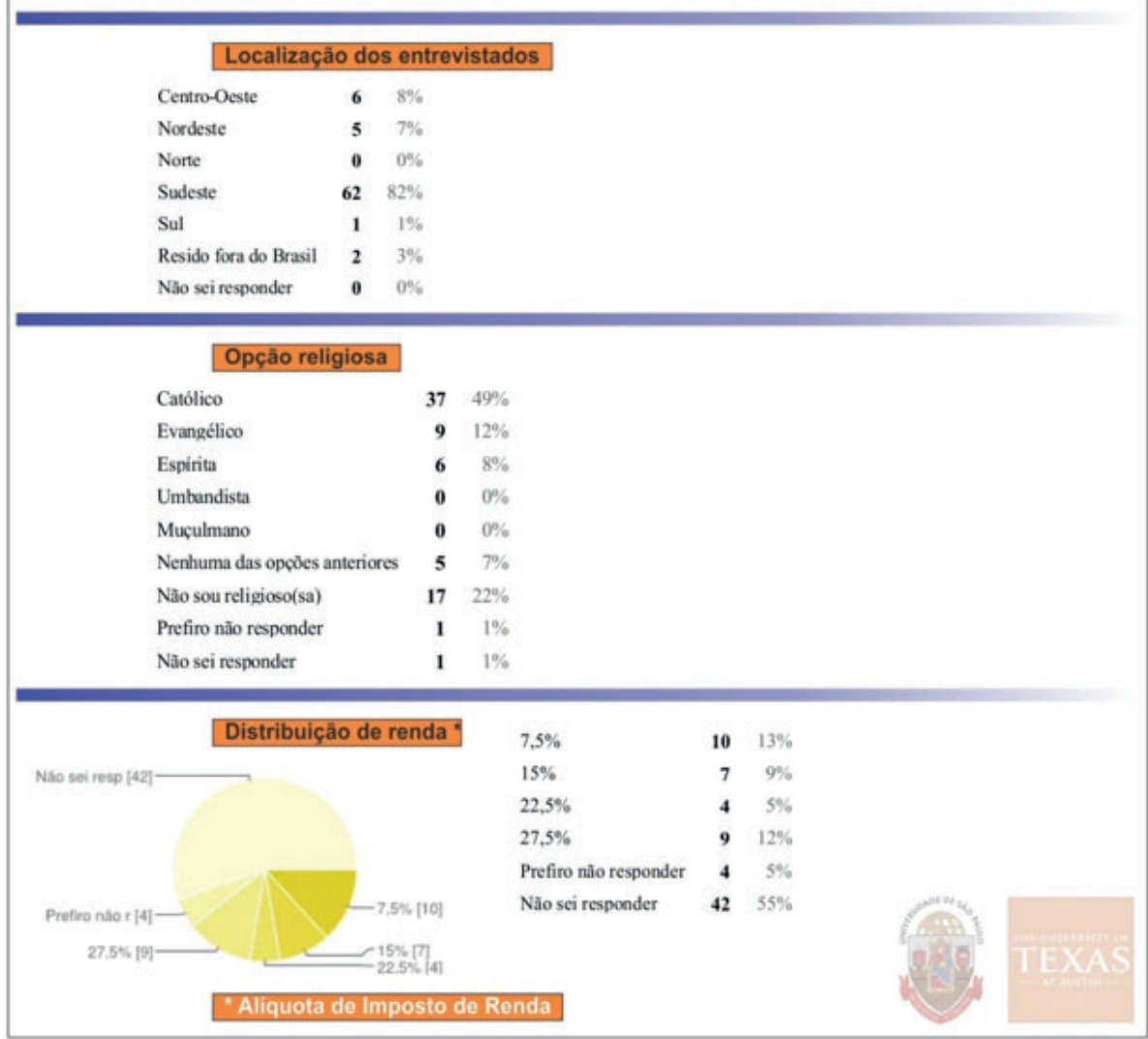

Foram cruzadas informações relacionadas a idade, sexo, distribuição por classe econômica e localização de origem, com objetivo de ênfase na denominada Nova Classe $C$. 
Foram escolhidas perguntas que, presentes no questionário on-line, objetivaram traçar o perfil socioeconômico dos entrevistados. A esse respeito, Straubhaar, no macro levantamento que faz na Universidade do Texas, nos EUA, sobre a América Latina, busca focar o que aqui no Brasil e nos demais países emergentes, em especial aqueles pertencentes ao bloco econômico BRICS ${ }^{13}$, é denominado como Nova Classe $\mathrm{C}^{14}$. Faixa etária prevalente de nascidos entre 1955 e 1994, ou seja, com idade entre 21 e 60 anos, cumprindo com a intenção primordial de nosso levantamento, qual seja, compreender as referidas gerações que Prenkys (2015) contextualizou como sendo composta por nativos e imigrantes digitais. Ainda, a maioria dos entrevistados tinha, no mínimo, nível superior, e a presença marcante de respostas advindas das regiões Sudeste, Centro-Oeste e Nordeste. Como estratégia para definição da classe econômica a que pertencem os colaboradores da pesquisa, optei por elencar as alíquotas de Imposto de Renda a que cada um, na então mais recente declaração para a Receita Federal, foi enquadrado. A expectativa da pesquisa, nesse item, foi frustrada pelo fato de a maioria haver afirmado "não saber responder". Entre os que apontaram a faixa de recolhimento do Imposto de Renda, houve prevalência de alíquotas mínima, de $7,5 \%$, e máxima, de $27,5 \%$, correspondendo, respectivamente, a classes que, tributadas na fonte, são entendidas como menos e mais abastadas.

Outra análise mostra o perfil de consumo midiático dos colaboradores da pesquisa (Figura 3). A intenção comum da investigação, no que pode ser comparado ao estudo desenvolvido por Straubhaar, foi cruzar informações relacionadas à posse e ao uso de mídias, tanto analógicas quanto digitais, em recortes de tempo histórico referentes às quatro gerações especificadas como público-alvo. Em diálogo de interação, os entrevistados informaram sobre o ano de aquisição do primeiro microcomputador, o tipo de telefonia móvel que detêm, a propriedade sobre aparelhos portáteis de rádio e o acesso a impressos. Dessa maneira, entendi, nos pressupostos metodológicos advindos da Universidade do Texas, que o cruzamento do perfil de consumo de mídias estabelece um padrão geral de acesso às tecnologias analógicas e digitais de comunicação, comprovando que por mais jovem que seja o entrevistado, ainda assim há consumo, por

${ }_{13}$ Grupo de países composto por Brasil, Rússia, Índia, China e África do Sul.

14A esse respeito, há pesquisas periódicas feitas pelo IBGE e pela Fundação Getúlio Vargas, que consideram Nova Classe C uma categoria da população brasileira que saiu das classes menos favorecidas a partir de 2003 , coincidindo com o início de gestão do Partido dos Trabalhadores na Presidência da República. 
exemplo, de jornais e revistas impressos, além de sintonia de rádios AM e FM em aparelhos convencionais, na busca por notícias. Por outro lado, gerações com idade acima dos 50 anos, em vez de priorizarem os veículos massivos de comunicação no consumo diário de conteúdos, apelam, na prática, para as tecnologias digitais, contemporâneas, em uma forma de acesso que surpreendeu as expectativas iniciais lançadas sobre o levantamento, em especial na resposta relacionada à assinatura de serviços on-line de informação.

Figura 2 - Consumo midiático

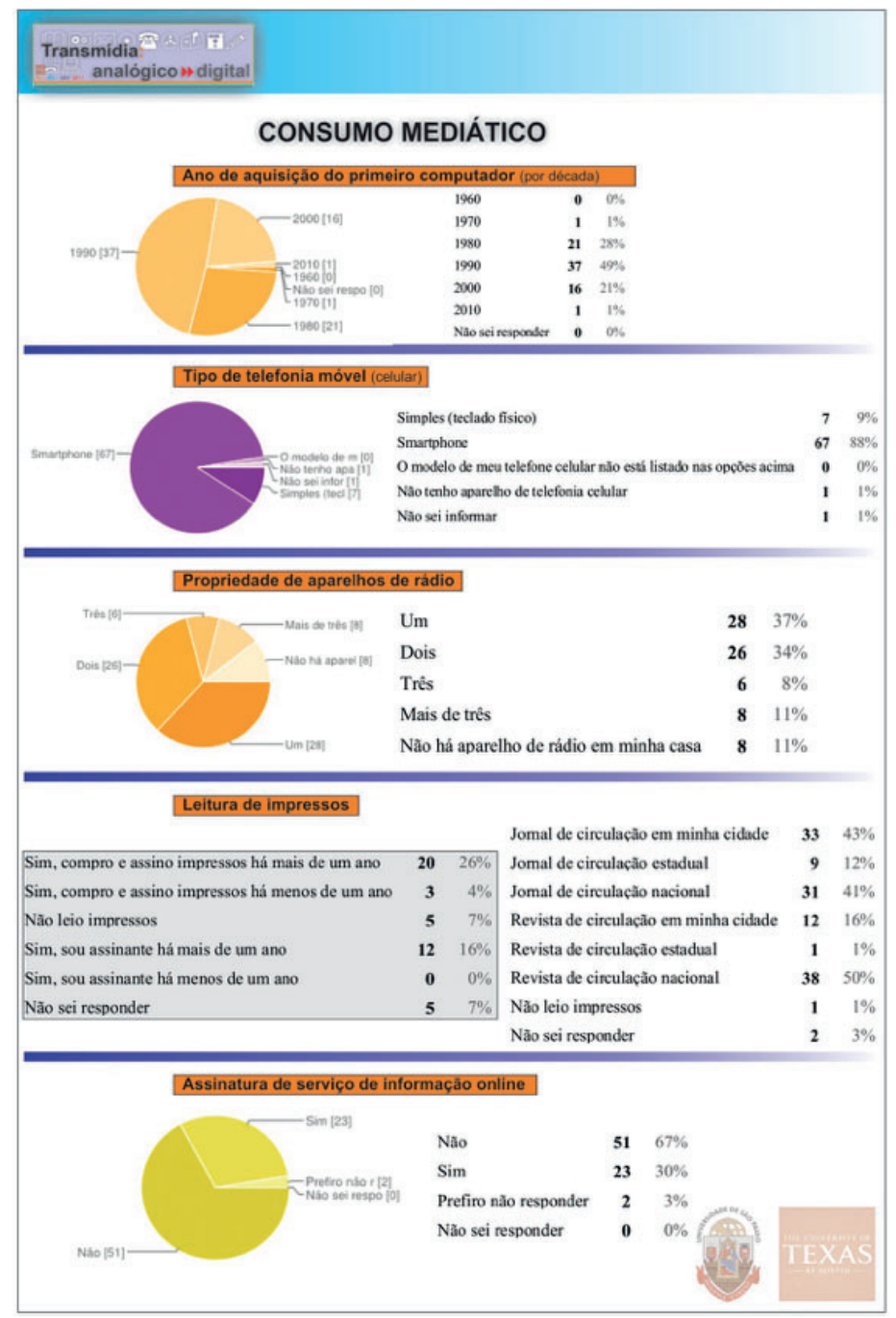

Essas questões tiveram por objetivo traçar o perfil de entrevistados quanto ao acesso às tecnologias, assim como a finalidade de uso no cotidiano social de tais recursos. 
Todavia, o cerne da pesquisa conjunta com a universidade norte -americana ficou relacionado à postura dos entrevistados quanto de questionamento relacionado ao uso simultâneo de no mínimo duas plataformas midiáticas para interação com um determinado tipo de conteúdo. Sobre esse aspecto, a investigação adotou a estratégia de buscar respostas das gerações de indivíduos com idade superior a 50 anos, com uma perspectiva metodológica, e abaixo dessa idade, mediante utilização de outro tipo de abordagem metodológica. Foram pesquisadas informações sobre os canais utilizados na procura por conteúdos midiáticos relacionados a artistas/músicas, tempo dedicado à TV, duração das conexões diárias na internet, sintonia em emissoras de rádio - independentemente da plataforma utilizada - e frequência de comparecimento ao teatro e ao cinema. Depois, em questões específicas, foram cruzadas as respostas relacionadas à interação de conteúdos que contextualiza o fenômeno transmídia, levantando a suficiência das estratégias traçadas pelos veículos de comunicação de massa, agora reconfigurados, conforme William (2003) e Giddens (1990), a partir de sujeitos da contemporaneidade mais interativos.

Pode ser considerado, ante ao exposto, que na transmidiação o comportamento interativo, criativo, remete a um protagonismo da audiência ainda não transformado em objeto nos estudos que, dependendo da perspectiva de abordagem, possam ser relacionados a mediação tecnológica ou à educomunicação. Ao ser parte do setor produtivo de conteúdo, devolvendo, através das redes sociais, aceitação ou não a determinados enunciados presente no discurso massivo das mídias, o sujeito social que compõe a audiência é, hipoteticamente, parte indireta do emissor nos processos comunicativos mediados, sem, com isso, ser relacionado à demonização acerca de eventual dominação presente em um conceito de Indústria Cultural reconfigurado.

\section{Considerações finais}

Busquei, nesse estudo apresentado, refletindo sobre a suficiência epistemológica do conceito "educomunicação", e enfatizando ser, esse, área do campo da inter-relação comunicação/educação e não um campo autônomo, encontrar elementos de subsídio quanto ao perfil de consumo de um amplo grupo de pessoas com idades que as enquadram em gerações de jovens, adultos e idosos. A metodologia de análise qualitativa contempla histórias de vida relacionadas à interação dos agentes com as mídias, de modo 
a conceber o quão protagonistas os mesmos foram e/ou são quando se relacionam com os meios produtores de conteúdo ou compartilham opiniões acerca do que consumiram.

O levantamento fez uma abordagem acerca da maneira como quatro gerações nascidas no Brasil, no período compreendido entre 1934 e a década de 1990, construíram suas histórias de vida relacionadas ao convívio com a tecnologia. São sujeitos sociais que, na condição de audiência, ora foram privilegiados pelo acesso restrito a aparelhos analógicos como o rádio e o televisor, ora cresceram na fase de transição entre as tecnologias analógica e digital, ou, ainda, ora praticamente nasceram com a popularização do acesso às plataformas digitais da contemporaneidade.

Excerto da pesquisa principal, este estudo considerou as classes sociais a que os investigados pertencem, com vistas a analisar o comportamento de consumo de conteúdos midiáticos entre agentes, levantando se há similaridades entre o que incide, em dados, sobre a denominada Nova Classe C e o que mostram as informações advindas, na mesma coleta, nas classes AB e DE. Foi aplicado um questionário on-line direcionado estrategicamente a um público que, em pré-análise dedutiva, possui a interação com a tecnologia em sua história de vida pessoal, seja na instância profissional, seja na rotina familiar.

O fenômeno observado, na perspectiva epistemológica da educomunicação, é o de transmidiação, numa forma de analisar se a busca complementar de informações sobre conteúdos midiáticos consumidos há quatro décadas, por exemplo, coincide com o que as gerações contemporâneas adotam, em expectativa de consumo, quando assistem TV, ouvem rádio ou vão ao cinema e interagem, em dias atuais, nas redes sociais, de forma concomitante ou a médio prazo.

A análise segue norteada pelos pressupostos teóricos da educomunicação, tendo por hipótese alterações sensíveis em duas vertentes, quais sejam, (a) a apropriação-adesão, pelas empresas produtoras de conteúdos, das-às mídias sociais e uma eventual abertura, nessas plataformas, para interação-participação da audiência e, em sentido contrário, (b) o uso das mídias sociais, por parte da audiência, para a crítica ou reivindicação de alteração de direcionamento dos conteúdos midiáticos consumidos. Em ambos os processos está em voga, entendo, o papel protagonista da audiência, cujas aceitação ou negação aos conteúdos enunciados são cada vez mais aceitas e servem de mote para revisão de estratégias e roteirizações da hegemonia de mercado por trás das mídias. 


\section{Referências}

BELTRÁN, L. R.; CARDONA, E. F. de. Comunicação dominada: os Estados Unidos e os meios de comunicação na América Latina. São Paulo: Paz e Terra, 1982.

FADUL, A. M. Cultura e comunicação: a teoria necessária. In: KUNSCH, M. M. K.; FERNANDES, F. A. M. Comunicação, democracia e cultura. São Paulo: Loyola, 1989.

Indústria cultural e comunicação de massa. 1993. Disponível em:

<http://www.crmariocovas.sp.gov.br/pdf/c_ideias_17_053_a_059.pdf>. Acesso em: 17 jul. 2015 .

GIDDENS, A. As consequências da modernidade. São Paulo: Editora Unesp, 1990.

Novas regras do método sociológico. Rio de Janeiro: Zahar, 1976.

HOBBS, R. Empowerment and protection: Complementary strategies for digital and media literacy in the United States. 2010. Disponível em: <http://works.bepress.com/reneehobbs/11/>. Acesso em 29 jan. 2016.

JENKINS, H. Cultura da convergência. São Paulo: Aleph, 2009.

JOHNSON, S.. Cultura da interface: como o computador transforma nossa maneira de criar e comunicar. Rio de Janeiro: Jorge Zahar, 2001.

LÉVY, P. A inteligência coletiva: por uma antropologia do ciberespaço. 4 a ed. São Paulo: Loyola, 2003.

Cibercultura. $2^{\text {a }}$ ed. São Paulo: Editora 34, 2000.

LOPES, M. I. V. de. (Org.) Estratégias de transmidiação na ficção televisiva brasileira. Porto Alegre: Sulina, 2013.

. Telenovela como recurso comunicativo. In: Matrizes. São Paulo: ECA/ USP/Paulus, ano 3, n.1, p. 21-47, 2009. 


\section{Linguagens nos modos de narrar: possibilidades e desafios para a Educomunicação ${ }^{1}$}

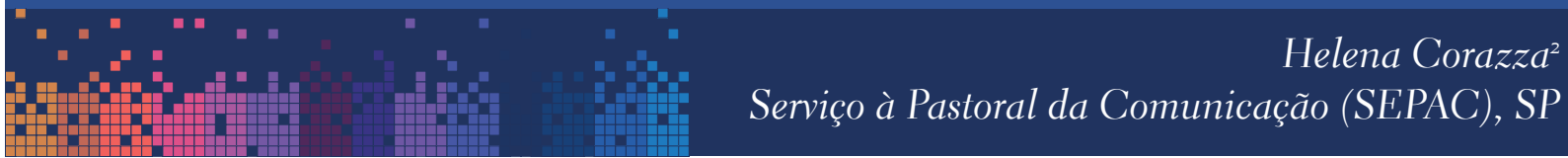

Este estudo pretende refletir sobre as diferentes linguagens no processo de comunicação e educação, muitas vezes consideradas apenas como técnicas. Elas desafiam o modo de comunicar, a interação entre as pessoas e sua compreensão dos conteúdos, uma vez que pouco se considera a produção de programas de rádio, vídeo, internet como linguagens. Assim como na escrita, os suportes técnicos e combinações estão presentes nas linguagens, o que requer apropriação do conhecimento, como acontece no processo de alfabetização textual.

As expressões plurais e sensoriais na linguagem oral, escrita, sonora, imagética, digital, de forma linear ou não linear, são maneiras de conhecer e narrar o mundo com janelas simultâneas, potencializadas pelas conexões da comunicação mediada pelas tecnologias e constituem desafios para a Educomunicação.

A linguagem como capacidade de falar é uma característica própria do ser humano, enquanto racional, o que garante sua interação social. Essa capacidade comunicativa no convívio social favorece a troca de mensagens, produzidas por um sistema de signos verbais, sonoros, visuais e táteis, que evoluem com as combinações e a hibridização da linguagem, de modo que a comunicação está em trânsito, conforme Citelli (1999), e se torna necessário estabelecer diálogos para a ampliação do campo educativo e comunicacional.

1 Trabalho originalmente apresentado no GP Comunicação e Educação do XV Encontro dos Grupos de Pesquisa em Comunicação, evento componente do XXXVIII Congresso Brasileiro de Ciências da Comunicação.

2 Jornalista, doutora em Ciências da Comunicação pela Escola de Comunicação e Artes da Universidade de São Paulo (ECA/USP). Diretora e docente no SEPAC (Serviço à Pastoral da Comunicação).E-mail: helena.corazza@paulinas.com.br; helenac@usp.br 
O sentido das linguagens aqui abordado é da complexidade das maneiras de narrar, assumidas pela mídia, da linguagem verbal, passando pelo texto escrito, visual, sonoro e do hipertexto; linguagens complexas, que "resultam da capacidade de se cruzar, numa mesma situação, vários tipos de signos, hibridizando-os" (CITELLI, 2006, p. 137).

\section{Metodologia e amostragem}

Partindo da reflexão elaborada em um dos capítulos da tese de doutorado $^{3}$ a respeito das linguagens como novas formas de narrar, ainda pouco refletida na Educomunicação, este artigo recupera alguns aspectos das mudanças na linguagem, considerando que ela se constitui e se expressa na combinação de elementos gráficos, visuais, sonoros, tanto no aspecto analógico quanto digital. Essa reflexão considera como as mudanças da técnica possibilitam novas linguagens do impresso ao digital.

Para fundamentar esta reflexão, foi aplicado um questionário por escrito para 15 cursistas participantes do laboratório de Rádio4, que exercita a teoria e a prática na produção de conteúdo. Responderam ao questionário quatro homens e quatro mulheres dos estados de PI, MG, ES, BA, CE e SP e uma da Argentina, que está no Brasil para estudos. A formação acadêmica dos que responderam é diversificada tendo a maioria cursado Filosofia e Teologia, uma tem Mestrado em Bíblia, uma é Publicitária, uma Designer, um Educador e uma Radialista cuja idade está entre 23 e 67. O campo de atuação está na área pastoral e educativa, com abrangência, em sua maioria, regional, local, nacional e internacional. As perguntas procuram verificar em que medida as linguagens são consideradas: se apenas como apropriação de técnicas ou como novas possibilidades de comunicar, abrindo para uma visão e canais de comunicação.

A Educomunicação, enfocada neste artigo, reúne em si os elementos da comunicação e a intencionalidade educativa a partir do espaço não

3 CORAZZA, Helena. Educomunicação: desafios e perspectivas na formação pastoral. A experiência do Serviço à Pastoral da Comunicação (SEPAC). ECA/USP, 2015.

4 Trata-se do Curso Cultura e Meios de Comunicação, uma abordagem teórico-prática do SEPAC, em convênio com a PUC-SP (COGEAE), cuja metodologia possibilita a apropriação do campo da produção em todo o processo. O laboratório de Rádio tem a carga horária de 5oh/aula. 
formal em que pessoas jovens e adultas, de formação acadêmica diversificada, refletem e produzem conhecimento na interface com a comunicação, apropriando-se de diferentes linguagens. Entre os elementos percebidos está a participação ativa, a apropriação do conhecimento e o exercício da produção, individual e em grupo, enfrentando os desafios das diferentes linguagens e a atuação prática ou trabalho de intervenção. Seguindo a metodologia teórico-prática que possibilita a apropriação e o exercício da produção que combina e organiza os elementos do texto escrito, da oralidade em suas diferentes expressões, o aprimoramento da comunicação pessoal com os diferentes gêneros e possibilidades no campo da informação, ficção e musical, o trabalho individual e coletivo acontece em todo o processo da produção cultural.

\section{Mudanças nas linguagens pelas tecnologias}

As mudanças nas linguagens não são apenas uma dimensão constitutiva da vida social, nem dizem respeito somente aos meios de comunicação, mas têm a ver com uma forma determinada de a própria sociedade ser e se configurar, vinculada à revolução tecnológica da modernidade que elevou a técnica como parte do progresso e da felicidade do homem. Por esta nova configuração, ela provoca uma reelaboração do caráter simbólico da vida social enquanto tal, ligada à pretensão moderna da realização tecnológica dos desejos humanos.

A revolução comunicativa provocada pelo desenvolvimento dos meios de comunicação modificou profundamente a comunicação humana nas sociedades contemporâneas e reestruturou de maneira radical as relações entre as pessoas (THOMPSON, 1998, p. 11), passando da comunicação face a face para a comunicação mediada pelo computador. As linguagens se constituem a partir da cultura e da técnica, por isso não podem ser compreendidas apenas como algo técnico, mesmo se servindo de diferentes recursos para se expressar. Sem entrar em questões mais profundas do conceito de técnica ou tecnologias, por não ser objeto deste artigo, Santaella (2013) adverte sobre a necessidade de compreender a linguagem própria da máquina, porque ela segue lógicas próprias. Neste sentido, procuraremos pensar sobre a técnica como um elemento que faz parte das linguagens mediadas pelas tecnologias e que reconfiguram os modos de narrar. 
Assim como a prensa manual do século XIV e a fotografia no século XIX exerceram um impacto revolucionário no desenvolvimento das sociedades e culturas modernas, hoje estamos no meio de uma revolução das mídias e uma virada nas formas de produção, distribuição e comunicação mediadas pelo computador que deverão trazer consequências muito mais profundas do que as anteriores (SANTAELLA, 2013, p. 192).

O fenômeno técnico nasce com a aparição do homem, depois enquadrado pelo discurso filosófico no qual a palavra técnica carrega o duplo sentido: de conhecimento, a technè, a arte, o saber das coisas práticas, para depois entrar no processo de cientifização com o surgimento da tecnociência que hoje se chama tecnologia. A épistémè, o conhecimento, o saber das coisas teóricas, mais identificada com o pensamento abstrato. A técnica é uma forma de desencobrir, desvelar as diferentes linguagens que transitam entre a épistémè e a technè, o que requer novas habilidades e saberes para se expressar.

Pensadores de diferentes áreas procuram compreender as linguagens para além do conhecimento teórico e abstrato desenvolvido pela inteligência racional, e abrirem-se a outros modos de compreensão e tipos de inteligência, como as inteligências múltiplas, em que Gadner (1994) considera os sentidos e as percepções como formas de conhecimento, na inteligência espacial, visual, auditiva, tátil, arte musical, corpo. A racionalidade que consolidou sua expressão na escola, pela disciplina, lógica, escrita, elaborações conceituais, passa a ser questionada com a chegada das novas tecnologias, que despertam outras formas de aprender e influenciam gradativamente os hábitos cotidianos percebidos pelos sentidos e pela emoção.

\section{Linguagem audiovisual e percepção sensorial}

Na década de 1960, o canadense Marshal McLuhan, da universidade de Toronto (1911-1980), vislumbrou a mudança de suportes culturais e sua incidência no ser humano. A "aldeia global", preconizada por ele, é uma forma de olhar para as mudanças tecnológicas, deslocando o estudo da comunicação da análise dos conteúdos para o exame dos meios de comunicação. Nas três galáxias que o teórico traz, a cultura oral ou acústica, dita e escutada; a cultura tipográfica ou visual de Gutenberg, identificada com o livro; a cultura eletrônica, dos sinais elétricos instantâneos, a velocidade, ele questiona os modos de apreensão do conhecimento unicamente pela escrita. McLuhan percebeu, por suas experiências com o livro, que este desenvolve 
a primazia do olhar em detrimento de outros sentidos e que as mídias eletrônicas passariam a envolver mais com o ouvir e os demais membros do corpo. Suas afirmações controvertidas e, para alguns, parciais, refletem uma questão de percepção das linguagens a serem consideradas no contexto atual.

O livro foi a primeira mercadoria produzida em massa. A imprensa, que por definição é uniforme e repetível, não só criou o próprio conceito de "mercadoria" como possibilitou o surgimento de mercadores para esses artigos uniformes e repetíveis. É perfeitamente natural pensar que a operação das formas e matrizes da linha de montagem da imprensa, quando se estendeu a todas as formas de produção, deve ter moldado também nossas atitudes para com as atividades da elite (McLUHAN, 2005, p. 37).

Seguindo outra lógica, a linguagem audiovisual desperta atitudes perceptivas, atinge a imaginação e investe na afetividade, na expressão dos sentidos para a percepção do mundo, enquanto a linguagem escrita desenvolve o rigor, a abstração e o espírito de análise. Para a cultura da escrita, a mensagem designa o conteúdo intelectual e está nas palavras, na coerência lógica que privilegia a consciência intelectual clara.

Ao contrário do homem de Gutenberg, treinado para a distância afetiva e para a desconfiança para com a imaginação, o homem da civilização audiovisual eletrônica liga intimamente a sensação à compreensão, a colaboração imaginária ao conceito (BABIN; KOULOUMDJIAN, 1989, p. 107).

Até a era da imprensa, a tecnologia avançou em estágios lentos de modo que as mudanças eram menos percebidas e desestabilizavam menos. Da oralidade ao manuscrito, da indústria ao digital, a sociedade foi se organizando tendo em conta as mudanças de suportes técnicos, e a velocidade tornou-se um componente que interfere na mudança. A sociedade industrial vivenciava e incorporava a emergência dos meios de comunicação com a Imprensa (1456), que socializava o conhecimento pela máquina de imprimir no suporte papel. O livro foi hegemônico por quatro séculos e os jornais tiveram 200 anos para inovar. Quatro séculos depois vem o Cinema (1895), que trabalha a imagem em movimento, 30 anos antes de ser sucedido pelo rádio, que descobre a possibilidade da emissão da voz à distância; a seguir, a televisão que populariza e institui um ritual da comunicação com imagem e som no cotidiano. Com o rádio e a televisão, surgem as formas de produção e armazenamento da informação em som e imagem, que passam por mudanças até chegar ao digital. 
A velocidade faz sentir menor distância entre uma invenção e outra, para não mencionar a escala milenar do pintor das cavernas. Do homem tipográfico, passando pelo telégrafo à televisão, o tempo das mudanças foi se abreviando. "A explosão de tipos de meios de comunicação no século XX nos permite, pela primeira vez, apreender a relação entre a forma e o conteúdo, entre o meio e a mensagem, entre a engenharia e a arte" (JOHNSON, 1997, p. 9). A velocidade é a característica das mudanças que contribuem para a criação de novas linguagens que vão se hibridizando pelas combinações, nos diferentes meios de comunicação, interferem no modo de pensar e criar. Com a televisão vem a supremacia da imagem sobre o texto e, em seguida, a World Wide Web, possibilitando a rede de conexões em alta velocidade.

Os pressupostos da comunicação sonora se estendem à comunicação audiovisual, na qual predomina a linguagem da modulação, o apelo aos sentidos, a sensorialidade, entre elas, o ouvido. O francês Pierre Babin, que trabalhou com McLuhan, considera essa comunicação como linguagem de modulação, na qual o sentir, o escutar é anterior ao falar e a tensão e receptividade são inerentes à expressão. Para o autor, a linguagem de modulação é a primeira que nasce já na vida intrauterina, é a relação com os pais, a comunicação na praça, no interior da família, uma primeira comunicação, matriz de outras.

Kerckhove (1997), sucessor de McLuhan, trabalha a ideia dos meios eletrônicos como extensões não só do sistema nervoso e do corpo, como também da psicologia humana. Baseado na ciência comportamental, aponta os efeitos físicos da televisão sobre o corpo e no sistema nervoso, entendendo que a televisão dirige o corpo e não o espírito por meio de respostas musculares subliminares. Nas mídias eletrônicas, a ênfase é dada à oralidade e ao tato, particularmente na sua relação com a linguagem e com a forma como processamos a realidade sensorial.

Essas considerações envolvem os sentidos, desde o pensar a produção de um texto escrito, sonoro, imagético ou musical, como as percepções pela vista, ouvido, tato, parecendo estar em contradição com o pensamento e uma educação que chame e desperte a consciência. Entretanto, Martín -Barbero e Rey (1999) também caracterizam "uma nova era do sensível” e questionam a postura da elite intelectual que "nos faz insensíveis aos desafios culturais que a mídia coloca" à geração que se diverte com games e vê cinema na televisão. Estas colocações podem ser um indicativo da busca de compreender as mudanças nos modos de comunicar que passa pelas diferentes linguagens. 
Referindo-se à visão de McLuhan no que diz respeito à informação eletrônica, mais da ordem do "ambiente" que da tecnologia, Sodré (2012) entende que há ali uma hipótese de uma "ecologia” intrínseca aos meios de comunicação, que não se trata apenas do ambiente, mas da interação humana decorrente da experiência educativa. "O que está verdadeiramente em questão é a existência de um novo bios [...] o bios virtual é, no limite, uma espécie de comunidade afetiva de caráter técnico e mercadológico, onde os impulsos digitais e imagens se convertem em prática social” (SODRÉ, 2012, p. 1988-1989).

Para o autor, a expressão "o meio é a mensagem”, cunhada por McLuhan, é uma formulação, embora incipiente, do bios virtual, por indicar que a forma tecnológica corresponde ao conteúdo. Essa nova forma de conviver em que técnicas, conteúdo e pessoas estão juntos e constituem uma única realidade e forma de convivência. As economias se interconectam entre si e se integram ao mundo em redes globais, criando um grande número de comunidades virtuais na interação digital, de acordo com os diversos interesses. A tecnologia passa a ser uma espécie de prótese que faz parte das relações sociais e da gestão nessa nova ambiência.

\section{Narrar na linguagem dos impressos e do rádio}

O historiador francês Chartier discute a perda da centralidade do livro com a chegada do digital pela mobilidade nos suportes mais estáveis até agora, como é o livro. Sendo a imprensa a primeira forma de transmissão, disseminação e circulação do conhecimento a partir do século XV, o historiador considera que essa revolução é técnica e caracteriza-se como uma revolução do impresso. Para ele, "a revolução da imprensa não consiste absolutamente numa 'aparição do livro'. Doze ou treze séculos antes do surgimento dessa nova técnica, o livro ocidental teria encontrado a forma que lhe permaneceu própria na cultura do impresso" (CHARTIER, 1998, p. 96).

McLuhan percebeu que a tecnologia cria uma ambiência para onde o homem transita, esse ambiente presente na atmosfera é algo invisível e se traduz em formas de perceber o mundo, hábitos e estilos de vida, com as tecnologias como prolongamento do corpo, ou próteses, conceito trabalhado por outros autores. Para Del Bianco (2005, p. 156),

a partir desse argumento, McLuhan concluiu que a era eletrônica abalou os fundamentos enraizados na experiência de mundo do homem 
tipográfico por que o colocou imerso num mundo visual, áudio-tátil, simultâneo e 'tribalizado' muito diferente do mundo linear e destribalizado criado pela cultura letrada. A palavra impressa fizera a civilização ocidental letrada homogênea, uniforme e unidimensional. O rádio, ao contrário, estabeleceu conexão íntima com a cultura oral, graças ao seu poder de envolver e afetar as pessoas em profundidade.

Para a autora, "o rádio é a tecnologia da tribo", que resgata o sentido de comunidade, a voz do quarteirão, o localismo, a magia tribal antes soterrada na memória, o acesso ao mundo não visual, a comunicação íntima e particular de pessoa a pessoa. Sendo parte da cultura oral, quando se aprende a produzir na linguagem radiofônica, entende-se que ela requer proximidade com a vida cotidiana, da conversa do dia a dia; daí a arte de escrever como se fala, de pensar na situação e no tempo do ouvinte imerso no seu cotidiano, dentro de casa, no trabalho, no trânsito, no hospital, nas mais diversas formas e, na era digital, ter em conta que ele ouve cada vez mais pelo celular. A cultura oral traz a proximidade como magia da tribo, o sentir-se juntos na linguagem nas temáticas regionais ou globais em cada segmento.

Rádio é linguagem, tecnologia, relacionamento, redes, convergência; é arte de comunicar com leveza, mais ligado ao lúdico e ao afeto; é fala que envolve a língua, a linguagem oral, a palavra, os sons, os efeitos especiais, a organização do discurso, a interlocução, a troca; compõe-se de técnica, também de linguagens e de vida cotidiana. Sua invenção está ligada à propagação da voz e de poder se ouvir a voz humana a distância. Esta foi a experiência do brasileiro, Landell de Moura, em suas descobertas pioneiras. Como há um aprendizado da oralidade pela convivência e pelo fato de ouvir outras pessoas, a escola prepara, sobretudo, para a aprendizagem da cultura letrada, reconhecer o alfabeto, aprender a ler e a escrever. Neste caso, não se observa uma separação entre a técnica e a linguagem, pois tudo resulta na linguagem.

As linguagens audiovisuais, talvez por virem depois e trabalharem com combinações de signos textuais, sonoros e imagéticos, são tratadas de técnicas até sem refletir, ou pelo senso comum de que a linguagem é a oral e a escrita. Dessa forma que chamamos de técnicas (técnica de redação, técnica de reportagem) e, não raro, os gêneros (informativo, musical, dramaturgia) assumem em si linguagens próximas da cultura oral e da vida cotidiana. A linguagem da palavra bem articulada, clara, modulada para ser agradável ao ouvido do interlocutor; a construção do discurso na sua ordem direta, com a repetição dos aspectos mais importantes na notícia, é uma das características da linguagem radiofônica, diferente da cultura do livro. A mixagem torna-se 
uma linguagem que une a voz, a sonoridade com vinhetas, efeitos sonoros com noções de espacialidade que ambientam o ouvinte é outra característica que considera a sensorialidade de criar imagens e sua própria narrativa a partir dos elementos verbais e sonoros oferecidos.

A portabilidade, tão decantada na tecnologia digital, é uma característica da linguagem do rádio, desde a invenção do transistor, favorece a atualidade do rádio, acima de outras formas de comunicação. Atualmente, pode-se dizer que o rádio abriu novos canais pela linguagem multimídia, sobretudo, no formato digital, com imagens, fotos, navegabilidade, num composto do hibridismo que caracteriza as mídias contemporâneas.

\section{A linguagem no rádio no olhar dos produtores}

Na experiência do laboratório de Rádio, trabalhando teoria e prática, exercitando a produção na prática, ao serem perguntados por que procuraram este curso, as respostas indicam a busca de "capacitação pessoal para servir melhor e dinamizar a comunicação", "adquirir conhecimento que possibilitem atuar e produzir comunicação", "para a minha formação e a missão com os meios de comunicação”.

Algumas respostas revelam a busca da inter-relação ou interface da comunicação com outras áreas do conhecimento como a Educação e a Bíblia: "melhorar a comunicação na educação", conforme um educador; “quero colaborar na Teologia Bíblica da comunicação de Deus com a humanidade”, diz uma docente que atua na formação bíblica de agentes pastorais e em cursos a distância.

Diante da indagação sobre o aprendizado prático "o que você mais quer aprender quando faz um laboratório”, as respostas podem ser agrupadas em aspectos de linguagem e das técnicas, do exercício prático e da coordenação. Fica evidente a necessidade da apropriação do conhecimento com "as técnicas e as linguagens específicas do laboratório", "a forma de comunicar a Palavra para a realidade atual, no contexto em que as pessoas vivem”. A principal busca é da apropriação dos conhecimentos práticos de “como melhor atuar na locução e apresentação", "como o laboratório estudado funciona na prática”, "técnicas do fazer e o funcionamento", "eu quero mesmo fazer, aprender técnicas, falar, fazer os exercícios". Por se tratar de lideranças, a busca de indicadores relativos à "organização dos conteúdos e coordenação”, “organização, elaboração, produção e coordenação de 
um programa de rádio", "as possibilidades do rádio hoje”, como "organizar o programa e atuar”, “como criar uma Rádio do início, meio e fim”.

Ao serem indagados sobre o que apreciam na metodologia do laboratório, os aspectos mais citados referem-se à "integração entre teoria e prática na forma expositiva (fundamentação), na forma de laboratório (exercício)", "a troca de experiências, o compartilhamento e a riqueza cultural do curso", "a participação ativa e criativa do aluno", "o trabalho em equipe", "a dinâmica das aulas e o método participativo", "o dinamismo, os recursos audiovisuais, metodologia e capacitação dos professores”.

É clara a necessidade de apropriação do conhecimento prático da linguagem, mais entendida como técnica, que possibilita o processo de criação. Esses aspectos recordam alguns valores que a Educomunicação tem em seus pilares para a formação cidadã, entre eles, o processo participativo, o ser humano como sujeito do processo, a apropriação ou empoderamento que desperta para a criação e a elaboração, proporcionando aos líderes se tornarem "intelectuais orgânicos" no processo educomunicativo. A troca de experiência e o compartilhamento de informações na diversidade cultural é um ponto mencionado no processo de participação.

Sabendo que as narrativas compõem-se de diferentes linguagens e gêneros como informativo, musical, teatral, ficcional, procuramos ainda saber se o cursista considera esses elementos importantes e como é seu cuidado na produção de um texto, um programa de rádio, a produção de conteúdos para as redes sociais. As considerações vão do cuidado com a língua portuguesa aos textos e a linguagem para cursos a distância. "É essencial prezar por uma linguagem e ortografias de acordo com os padrões vigentes da língua portuguesa até quando também há uma linguagem de fácil entendimento pelos leitores”, "para haver uma boa comunicação é necessário uma linguagem compreensível”. Esse cuidado está na preocupação com a simplicidade. "Escrevo para o curso EAD de Teologias Bíblicas. Busco encontrar uma linguagem aceitável, simples, sem omitir o que é fundamental sobre cada conteúdo pelo fato de ser mais difícil e exigente”.

De fato, as redes não são apenas técnicas, mas sociais, e configuram a sociabilidade na esfera pública na disseminação do conhecimento em diferente áreas. Elas “misturam lógicas, velocidade e temporalidade tão diversas como as que entrelaçam as narrativas orais, com a intertextualidade das escritas e a intermedialidade do hipertexto" (MARTÍN-BARBERO, 2014, p. 111).

$\mathrm{O}$ cuidado da linguagem, expressar-se com clareza, também "depende do público-alvo e é de extrema importância”. Contribuições revelam o 
olhar funcionalista em relação aos conteúdos: "na linguagem está a mensagem ou a eficiência da mesma. É ela que produz ou não o efeito esperado", “creio que a linguagem correta e direta contribui para a assertividade", diz outro cursista. A partir de quem trabalha no Rádio, "quando produzimos devemos ter em mente a responsabilidade que isso traz e os efeitos que pode gerar".

Tendo em vista que a pessoa é comunicação, perguntamos se o modo de comunicar (voz, postura, modo de se apresentar) faz a diferença na comunicação. Embora pouco elaboradas, as respostas indicam uma reflexão de que "o canal, o como da transmissão é fundamental"; "para que haja uma comunicação efetiva é necessário desenvolver todos os meus dons para que a comunicação ocorra com sucesso e exatidão". Também porque "envolve as pessoas, desperta interesse e participação", e que "faz toda a diferença. Na verdade, no mundo da comunicação está a diferença entre ser ou não ser ouvido”, "porque reflete a sua convicção, segurança, coerência e interesse no tema tratado".

O modo de comunicar supõe o conceito de modulação: a vibração que chega às pessoas e as toca. Ela não se restringe às palavras, mas envolve a percepção, a ambiência, o som, a presença. O discurso-palavra pode opor-se à modulação, se não contém aquela carga que contagia, enquanto a fala pode estar mais próxima da modulação, pois ela está em alguém, exprime uma intenção e uma presença que se revela. O exemplo da vibração das imagens e da música que toca o corpo é a FM (frequência modulada) e o conforto de escutá-la.

\section{Narrar nas linguagens na Cibercultura}

A cibercultura tem lógicas próprias, como linguagem não linear e interativa, sendo potencialmente um espaço democrático, pela liberação do polo do emissor. Muda o processo comunicacional de modo que na rede pode-se produzir conteúdo, enquanto na comunicação de massa a competência é dos jornalistas, profissionais e empresas. Com o acesso ao código, qualquer pessoa pode produzir, postar em seu blog, site ou nas redes sociais digitais. Essa reconfiguração pode ser percebida na combinação de diferentes linguagens em texto, som, imagens estáticas ou em movimento e navegabilidade, conforme projeto da arquitetura da informação, culminando em redações convergentes com um novo profissional.

Assim cada transformação midiática altera nossa percepção espaçotemporal. Lemos (2002) caracteriza cibercultura como as mudanças na cultura contemporânea, associadas às tecnologias digitais, que compreendem o 
ciberespaço, a simulação, o tempo real, o processo de virtualização e como cria uma nova relação entre a técnica e a vida social.

Compreender os desafios da cibercultura nos obriga a buscar, nas raízes do fenômeno técnico, a compreensão da cultura contemporânea. Não podemos compreender os paradoxos, as potencialidades e os conflitos da tecnologia na atualidade sem uma visão da história da tecnologia e de seus simbolismos respectivos, sem ter percorrido as principais correntes da filosofia da técnica (LEMOS, 2002, p. 25-26).

O rádio é uma mídia que se adaptou à linguagem da internet abrindo novos canais de comunicação com seu público. Não se trata apenas de transmitir a programação já existente pela internet, mas de se adequar a essa linguagem multimídia digital. A web rádio pode ser configurada nesse modelo e o ouvinte que antes participava por telefone, pode interagir de forma colaborativa com informações e produções. Segundo Prata (2009, p. 70-71),

o casamento entre rádio e internet certamente acompanhará este processo e, num futuro bem próximo, soará como linguagem ultrapassada a emissora que não oferecer, além do áudio, também conteúdos imagéticos e textuais ao seu público, ampla possibilidade de canais, intensa interação com o receptor e possibilidade real de produção de conteúdo por parte do usuário.

Os novos canais para a comunicação radiofônica são uma realidade comprovada no cotidiano dos que se informam por dispositivos móveis, como o celular para ouvir e interagir com a rádio a partir do lugar onde se encontram, narrando fatos, informando e opinando. A produção de conteúdos para a web que agrega as diferentes linguagens e requer um projeto editorial e a arquitetura da informação para macro e micronarrativas, que envolve a hierarquização da informação e a navegabilidade, é um recurso de linguagem e um desafio a ser incorporado: "escrever para ser ouvido, com as imagens ditando a narrativa” (SCHWINGEL, 2012, p. 99).

\section{A linguagem como prática da conversação na rede}

A complexidade das linguagens traz múltiplas possibilidades de escolhas em novas formas de conversação pelas mídias digitais com os chats ou conversas on-line que trazem formas abreviadas do código da língua portuguesa. É uma retomada da conversação cotidiana pela comunicação 
mediada em tempo real, estando os interlocutores em interação recíproca e simultânea com uma dinâmica própria. São duas ou mais pessoas que se comunicam nas diversas formas de interesse, das conversas para projetos comuns a estabelecer ou reforçar laços sociais.

Trata-se de uma linguagem, entendida como "internetês", que retoma a escrita com outras características da internet, entre elas, a oferta de múltiplos recursos, a velocidade operacional em tempo real, a interatividade digital. O ambiente da internet traz consigo o texto, o som, a imagem estática ou em movimento e o sujeito sente-se em liberdade para inovar sem aparente controle de normas linguísticas ou de pessoas, o que favorece a inovação na linguagem.

Alguns aspectos da conversação na rede representam espaços de lazer, "lugares virtuais onde as práticas sociais começam a acontecer, seja por limitações do espaço físico, seja por limitações da vida moderna, seja apenas pela comodidade da interação sem face” (RECUERO, 2012, p. 17). Estas são novas formas de estar juntos na sociedade contemporânea a partir de práticas de relacionamento no ciberespaço, também utilizada para causas sociais.

Uma das características da conversação mediada pelo computador é que o meio a transforma, sendo que a maior parte dessa conversação opera sobre bases com predominância textual, introduzindo uma hibridização das linguagens escrita e oral, algumas vezes, com vídeo e voz. Outra forma de expressar a entonação vocal e a expressão facial, bem como os gestos que acompanham o enunciado, é a apropriação de caracteres simbólicos, como o uso de emoticons, ou seja, "conjuntos de caracteres do teclado que simbolizam expressões faciais como sorriso, tristeza” (RECUERO, 2012, p. 46), ou sons onomatopaicos com a repetição de letras para dar a sonoridade desejada.

A conversação na rede assume um caráter híbrido, alinhando elementos da língua falada e escrita e possui caráter dialógico próprio da fala, realizado na tela do computador. Melo (2010, p. 46) entende que o que acontece com o "internetês" não é simplesmente a modalidade da escrita ou a modalidade falada da língua, mas outro nível mais complexo: "marcas da oralidade presentes na escrita eletrônica”. Essas marcas atingem a conjugação verbal, a grafia fonética, a pontuação, a estrutura paralinguística para expressar as emoções. 


\section{Considerações finais}

Os novos modos de narrar dizem respeito às múltiplas formas das condições do saber e compartilhar conhecimentos com as diferentes linguagens que estimulam um novo sensorium, com possibilidades e desafios. Como parte do cotidiano, as linguagens possibilitam o diálogo e a proximidade com o interlocutor, sobretudo, as crianças e os jovens. Conteúdos da história da humanidade com formatos novos de sonoridade, visualidade e acesso por tantos canais de comunicação disponíveis no dia a dia.

A formação de novos produtores de conteúdo, além dos profissionais da comunicação, lideranças de todas as áreas, produtores populares, educadores, intelectuais de diversas áreas apropriam-se do conhecimento e trabalham na interface com a comunicação. Aprender ou apropriar-se de novas "técnicas" de comunicação é trabalhar o empoderamento de tantos que não têm acesso à informação hegemônica, mas como sujeitos do processo, têm sua palavra a dizer para a sociedade.

Entre os desafios, há necessidade de aprofundamento do conceito de linguagem, tradicionalmente ligada à oralidade, ao texto escrito e literário, abrindo para outras formas de conhecimento como o audiovisual e o digital. Daí a necessidade de continuar investindo na formação de educadores e lideranças para que entrem com competência nas linguagens para a educação e a cultura. Há, sem dúvida alguma, uma mudança cultural e tecnológica acontecendo para a qual educadores e lideranças precisam estar atentos e ver como integrar a gama de conhecimentos existentes com as novas linguagens que também já se traduzem pela presença ou ausência na rede.

Continua o desafio de aliar a reflexão às práticas de produção para que a apropriação do conhecimento seja enriquecido com a compreensão das linguagens das mídias eletrônicas e digitais, sem considerá-las apenas técnicas no uso instrumental ou linguagem de segunda categoria.

A dimensão social das linguagens associa-se a técnicas que possibilitam a materialidade textual, sonora, imagética, digital, com suportes técnicos, nem por isso sendo confundida com "técnicas", pois são novas formas e canais de comunicação. 


\section{Referências}

BABIN, P.; ZUKOWSKI, A. Midias, chance para o Evangelho. São Paulo: Loyola, 2005 .

.; KOULOUMDJIAN, M. F. Os novos modos de compreender a geração do audiovisual e do computador. São Paulo: Paulinas, 1989.

CHARTIER, R. A ordem dos livros. Brasília: Ed. UnB, 1998.

CITELLI, A. Palavras, meios de comunicação e educação. São Paulo: Cortez, 2006.

Comunicação e educação: a linguagem em movimento. São Paulo: SENAC, 1999.

DEL BIANCO, N. O tambor tribal de McLuhan. In: MEDITSCH, E. Teorias do Rádio. Textos e contextos. Vol 1. Florianópolis: Insular, 2005, p. 153-162.

GARDNER, H. Estruturas da Mente. A Teoria das Inteligências Múltiplas. Porto Alegre: Artes Médicas, 1994.

JOHNSON, S. Cultura da Interface. Como o computador pode transformar nossa maneira de criar e comunicar. Rio de Janeiro: Zahar, 1997.

KERCKOVE, D. A pele da cultura. Relógio D’Água: Lisboa, 1997.

LEMOS, A. Cibercultura: tecnologia e vida social na cultura contemporânea. Sulina: Porto Alegre, 2002.

McLUHAN. M. McLuhan por McLuhan: entrevistas e conferências inéditas do profeta da globalização. Rio de Janeiro: Ediouro, 2005.

MARTÍN-BARBERO, J. A comunicação na educação. São Paulo: Contexto, 2014. .; REY, G. Os exercícios do ver. Hegemonia audiovisual e ficção televisiva. São Paulo: SENAC, 1999.

MELO, L. M. de. VMS TC??? Internetês: prática conversacional na WEB. Monografia PUC-SP (COGEAE)/SEPAC. São Paulo, 2010.

PRATA, N. Webradio, novos gêneros, novos formatos, novas formas de interação. Florianópolis: Insular, 2009. 
RECUERO, R. A conversação na rede. Comunicação mediada pelo computador e redes sociais na Internet. Porto Alegre: Sulina, 2012.

SANTAELA, L. Comunicação ubíqua. Repressões na cultura e na educação. São Paulo: Paulus, 2013.

SCHWINGEL, C. Mídias digitais. Produção de conteúdo para a web. Paulinas: São Paulo, 2012.

SODRÉ, M. Reinventando a educação. Diversidade, descolonização e redes. Petrópolis: Vozes, 2012.

THOMPSON, J. B. A mídia e a modernidade. Uma teoria social da mídia. Petrópolis: Vozes, 1998. 


\section{PARTE 2}

Processos educacionais e comunicacionais para formação do profissional de Comunicação 


\title{
Desenvolvimento de capital cultural digital e prossumidores: perspectivas de atuação em rede para os formandos em jornalismo ${ }^{1}$
}

\author{
Cláudia Maria Moraes BREDARIOLI ${ }^{2}$ \\ ESPM, São Paulo, SP
}

Diante da lógica mercadológica imposta na contemporaneidade pela tecnologia, os formandos dos cursos de Comunicação Social com habilitação em Jornalismo têm necessidade de uma formação de alta complexidade para conseguir atingir um patamar que os permita se mover com mais facilidade em uma área cujas oportunidades de emprego são cada vez mais raras, enquanto, ao mesmo tempo, cresce a demanda por serviços de Comunicação. Identificamos um cenário no qual os profissionais que ingressam no mundo do trabalho têm que primeiramente satisfazer à lógica mercadológica - por exemplo, respondendo aos estímulos para produzir conteúdos gratuitos em rede -, antes de disputarem os postos de trabalho cada vez mais frágeis que lhes são oferecidos atualmente.

Dessa forma, o percurso de reflexão desse artigo atravessa três etapas principais. A primeira delas apresenta alguns dos resultados captados pela análise da pesquisa empírica por nós realizada para o desenvolvimento de tese doutoral (BREDARIOLI, 2014a). A seguir, apresentamos um retrato resumido de alguns dos desafios enfrentados por jovens jornalistas que ingressam no mercado. Finalmente, tentaremos aproximar esse panorama de algumas das discussões atuais sobre o papel dos prossumidores (produtores + consumidores, conceito que será explicitado adiante) para podermos pensar

1 Trabalho originalmente apresentado no GP Comunicação e Educação, Congresso INTERCOM, Rio de Janeiro, 2015. Texto atualizado para esta publicação.

2 Professora da Escola Superior de Propaganda e Marketing de São Paulo (ESPM), SP, doutora em Ciências da Comunicação pela Escola de Comunicação e Artes da Universidade de São Paulo (ECA/USP). E-mail: cbredarioli@yahoo.com.br. 
em questionamentos acerca dos processos de inserção no mundo do trabalho por parte dos que se formam nesta área.

Os discursos captados para essa análise foram coletados por meio de questionários e entrevistas para avaliar como esses jovens formandos e recémformados em Jornalismo olham para a própria profissão e para o momento em que vivem³. Expõem ainda a relação de ethos e alteridade manifestadas nas declarações sobre desejos e expectativas pessoais e profissionais que revelam as percepções que têm de si e do outro, além de esclarecer pontos sobre as relações que estabelecem com os dispositivos midiáticos que os cercam.

Avaliamos esse cenário considerando que a geração que hoje está na universidade ou recém saiu dela é a primeira de nativos digitais (conforme Marc Prensky (2001) referindo-se aos que cresceram cercados por tecnologias digitais) que chega ao mercado de trabalho no Brasil. Vale tomar-lhe como ponto de partida para começarmos a compreender como se dá a formação de um capital cultural digital interativo que torne os indivíduos aptos a se apropriarem das mídias e, a partir delas, galgarem degraus no processo de inserção social. Pensamos o conceito de capital cultural digital a partir da proposição de Bourdieu (1998, 2005, 2008) para capital cultural e social, que envolve a formação e qualificação dos cidadãos a partir das diferentes experiências de aprendizado às quais estão expostos, não apenas no ensino formal. A ideia do capital cultural digital (BREDAROLI, 2014a) propõe trazer esse conceito de Bourdieu para o uso das novas tecnologias e para a capacidade de produção e mobilidade diante delas.

Bourdieu pontua que as necessidades culturais são fruto da educação. Para ele, “o ‘olho’ é um produto da história reproduzido pela educação" (BORDIEU, 2008, p. 10). Nesse contexto, vemos que novas regras sociais, econômicas, políticas e culturais têm se imposto aos processos de inserção

3 Nossos dados foram captados por meio de 37 questionários válidos respondidos. Para complementar as informações captadas por meio deles, optamos pela técnica de entrevistas com o intuito de perguntar a alguns dos participantes mais detalhes sobre sua formação e história de vida. Nossa amostra foi composta, aleatoriamente, por 40\% de homens e 60\% de mulheres. Do total de 37 respondentes, 17 cursaram a maior parte do Ensino Fundamental e do Ensino Médio em escolas públicas, sendo que os outros 20 fizeram escola particular. Interessante notar que 21 deles estão estudando, contra 16 que, por ora, não têm vínculo estudantil. Dos que estudam atualmente, 11 cursam pós-graduação, e 5, graduação. Consideramos alta a quantidade de pessoas que declarou estar trabalhando na área para a qual se formou, 26, diante de 11 que afirmaram atuar profissionalmente em atividades que não estão diretamente relacionadas à Comunicação. 
social dos cidadãos. E isso se percebe cada vez com mais clareza na fase que antecede a entrada no mercado de trabalho. Essas regras agora já não se restringem mais a dar mais oportunidades a quem frequentou bons colégios, viajou bastante, domina diferentes idiomas ou recebeu incentivos dentro de espaços artísticos e culturais ao longo da vida. Evidentemente que condições assim são centrais e catapultam a um patamar mais alto aqueles que delas desfrutam. Porém, outras interferências apontam para cenários mais rígidos e complexos de inclusão, o que ampliaria ainda mais a metragem dos degraus de separação. Transgredir esses limites envolve a capacidade de apropriação cultural que tem "valor de sagrado", segundo Bourdieu (1998).

Ele destaca que as diferenças de acesso à cultura e de aquisição desta entre os grupos sociais conferem aos mais privilegiados um poder real e simbólico que os habilita a apresentar os melhores desempenhos escolares. Diante do advento das novas mídias, o que vemos, contudo, é que vários outros agentes estão em ação, além dos tradicionais (escola, família, igreja). Dessa forma, as questões envolvidas nesses processos de acesso também mudam, configurando novas condições para a formação, inclusive do gosto e, consequentemente, da construção de capital cultural.

Segundo Recuero (2009), o uso de sites de redes sociais para a construção de capital social é eficiente e modificador para influenciar os valores mais direcionados à construção e à manutenção da rede dos indivíduos. Assim, teríamos aqui outra das expressões contemporâneas possíveis para estabelecer conexão com nossa ideia de capital cultural digital no sentido que as relações sociais (e também as econômicas e políticas) têm se estabelecido na esfera das redes, exigindo cada vez mais o desenvolvimento desse capital cultural digital.

É sob esse aspecto que propomos a ideia de "atualizar" o conceito de capital cultural de Bourdieu para as novas tecnologias - vistas enquanto sustentação do capitalismo global -, conceituado por nós como capital cultural digital, algo que está relacionado à capacidade de os cidadãos atuarem na rede (e consequentemente na sociedade) e apreenderem o potencial de uso desse espaço virtual. No nosso entender, esse seria um dos processos centrais para que, neste mundo contemporâneo, o homem consiga alcançar sua condição de "ser da práxis, da ação e da reflexão" (FREIRE, 2011, p. 30). Segundo o educador, somente a partir desta possibilidade de atuar, o sujeito seria capaz de transformar e criar uma realidade que, por sua vez, condiciona sua própria forma de atuar. "O homem que não pode ser compreendido fora de suas relações com o mundo, de vez que é um 'ser-em-situação’, é também um ser do trabalho e da transformação do mundo” (FREIRE, 2011, p. 30). 
Pensamos na construção de um capital cultural digital que permitia o desenvolvimento de habilidades e condições para reduzir barreiras, constituído por outras esferas ligadas especialmente à capacidade de produção em rede - algo que se tornou central na era digital. A construção e o desenvolvimento desse capital poderiam permitir, então, alcançar o nível de autonomia de atuação no mundo contemporâneo do qual trata Castells (2013). Cabe-nos pensar, porém, em como romper as barreiras interpostas no trajeto para chegar a essa autonomia? Por isso, referendamos a relevância dos processos de aprendizado e apreensão a partir das colocações de Paulo Freire. Em Extensão ou comunicação?, o educador coloca que:

Conhecer é tarefa de sujeitos, não de objetos. E é como sujeito, e somente enquanto sujeito, que o homem pode realmente conhecer. Por isso mesmo é que, no processo de aprendizagem, só aprende verdadeiramente aquele que se apropria do aprendido, transformando-o em apreendido, com o que pode, por isso mesmo, reinventá-lo; aquele que é capaz de aplicar o aprendido-apreendido a situações existenciais concretas (FREIRE, 2011, p. 29).

Neste contexto, entre os agentes socializadores (conceito atribuído pelas Ciências Sociais aos que contribuem para o desenvolvimento e para a inserção dos indivíduos, como a escola, a família, a igreja, os meios de comunicação, entre outros), demos prioridade em nosso estudo ao papel das novas mídias no contexto da formação do cidadão. Conforme vemos exposto na ementa deste grupo de pesquisa (GP Interfaces Comunicacionais - Comunicação e Educação do Intercom), "os estudos na interface Comunicação e Educação, marcados pelas interferências dos processos comunicacionais no contexto educacional, apontam a importância cada vez mais evidente da tecnologia no âmbito da educação formal e não-formal". Além disso, temos ainda que "a convergência das linguagens midiáticas provocam impactos na maneira de aprender e ensinar, nos modos de perceber, sentir e pensar as relações humanas em suas práticas sociais". Consequentemente, destacamos que também está o processo de inserção no mundo do trabalho dos egressos dos cursos de graduação - alvo central de nossa pesquisa.

Nossa análise foi permeada, especialmente, pelo conceito de alteridade e seu princípio de que o homem, na sua vertente social, estabelece uma relação de interação e dependência em relação ao outro. Dessa forma, os discursos apresentados ressaltam as condições de sociabilidade e diferença entre o indivíduo e o conjunto - uma circunstância central no ambiente digital vivenciado em rede. Esse tema alcança diversos pontos que deflagram 
por vezes uma relação de oposição entre o sujeito pensante e aquilo que lhe é distinto. Transportando essa conjuntura para o cenário de nossa análise, pulula por entre as palavras e frases digitadas por nossos entrevistados a condição de "sabedores" do mundo, no sentido em que eles se colocam, conforme será mostrado, na condição de observadores críticos da realidade midiática contemporânea a partir daquilo que expressam sobre si. Deixam ao mesmo tempo transparecer, porém, suas necessidades e interesses em se integrarem ao sistema tal como ele se apresenta.

Tudo isso nos fez sentido, diante da análise de ethos discursivo, segundo Maingueneau (2009, p.10), no contexto de que parece ser "claro que esse interesse crescente pelo ethos está ligado a uma evolução das condições do exercício da palavra publicamente proferida, particularmente com a pressão das mídias audiovisuais e da publicidade”. Assim, de acordo com o autor, o destinatário atribui a um locutor inscrito no mundo extradiscursivo traços que são em realidade intradiscursivos, já que estão associados a uma forma de dizer.

O ethos se elabora, assim, por meio de uma percepção complexa, mobilizadora da afetividade do intérprete, que tira suas informações do material linguístico e do ambiente. Há ainda algo mais grave: se se diz que o ethos é um efeito de discurso, supõe-se que podemos delimitar o que decorre do discurso; mas isso é muito mais evidente para um texto escrito do que numa situação de interação oral. Há sempre elementos contingentes num ato de comunicação, em relação aos quais é difícil dizer se fazem ou não parte do discurso, mas que influenciam a construção do ethos pelo destinatário. É, em última instância, uma decisão teórica: saber se se deve relacionar o ethos ao material propriamente verbal, atribuir poder às palavras, ou se se devem integrar a ele - e em quais proporções - elementos como as roupas do locutor, seus gestos, ou seja, o conjunto do quadro da comunicação. O problema é por demais delicado, posto que o ethos, por natureza, é um comportamento que, como tal, articula verbal e não-verbal, provocando nos destinatários efeitos multi-sensoriais (MAINGUENEAU, 2015, p. 15).

Os recortes analisados apontaram para os esforços de construção de uma imagem profissional e pessoal positiva de cada um dos formandos. Por isso, com frequência, os autores dos blogs elencam para si qualidades estereotipadas, a partir das quais tentam mostrar que são pessoas informadas, críticas, conectadas e confiáveis, etc. Há claramente uma necessidade de verbalizar tais características para a construção dessa imagem amigável, cujo objetivo é tornar-se uma pessoa popular e, consequentemente, obter novos 
seguidores na rede, buscando chamar a atenção dos usuários para que seus perfis sejam visitados. Fica evidente também que o objetivo desta autovalorização é a confirmação do outro, uma vez que o que importa aos locutores, de fato, é o que o outro vai pensar. É esse outro que se quer atingir. Afinal, o fato de os jovens jornalistas postarem na rede conteúdos que consideram relevantes mostra, desde o princípio, que essa exposição é um caminho que pode lhes trazer a possibilidade de reconhecimento por parte do outro, permitindo a construção de notoriedade. Nesse sentido, ressaltamos que, conforme argumenta Maingueneau (2008), o discurso do orador está dentro das expectativas dos demais usuários.

Ruth Amossy (2013) destaca que todo ato de tomar a palavra implica a construção de uma imagem de si. Para tanto, não é necessário que o locutor faça seu autorretrato, detalhe suas qualidades, nem mesmo que fale explicitamente de si. Seu estilo, suas competências linguísticas e enciclopédicas, suas crenças implícitas são suficientes para construir uma representação de sua pessoa. Assim, ela destaca que, deliberadamente ou não, o locutor efetua uma apresentação de si em seu discurso. "A apresentação de si não se limita a uma técnica apreendida, a um artifício: ela se efetua, frequentemente, à revelia dos parceiros, nas trocas verbais mais corriqueiras e mais pessoais" (AMOSSY, 2013, p. 9).

Segundo Amossy (2013), a função da imagem de si e do outro construída no discurso se manifesta plenamente nessa perspectiva interacional. "Dizer que os participantes interagem é supor que a imagem de si construída no e pelo discurso participa da influência que exercem um sobre o outro" (AMOSSY, 2013, p. 12). Assim, acrescenta a autora, uma vez que é "inerente a toda troca verbal e submetida a uma regulamentação sociocultural”, ela supera largamente a intencionalidade do sujeito que fala e age.

Se cada tipo de discurso comporta uma distribuição preestabelecida de papéis, o locutor pode escolher mais ou menos livremente sua cenografia. No discurso político, por exemplo, o candidato de um partido pode falar a seus eleitores como homem do povo, como homem experiente, como tecnocrata etc. A maneira de dizer autoriza a construção de uma verdadeira imagem de si e, na medida que o locutário se vê obrigado a depreendê-la a partir de diversos índices discursivos, ela contribui para o estabelecimento de uma inter-relação entre o locutor e seu parceiro (AMOSSY, 2013, p. 15).

Partindo também da declaração de Maingueneau (2013) de que a fala, desde sua emergência, pressupõe uma certa cena de enunciação, 
destacamos que o contexto da sociedade em rede e das conexões estabelecidas por meio da internet, como vimos, reconfiguram os processos culturais e as práticas profissionais. É neste contexto que a imagem construída de si valida e legitima o próprio discurso, considerando, necessariamente, que a cenografia, ao mesmo tempo, tanto atua como o espaço de onde vem o discurso quanto é por ele engendrada. “A cenografia legitima um enunciado que, por sua vez, deve legitimá-la, deve estabelecer que essa cena de onde a fala emerge é precisamente a cena requerida para enunciar, como convém, a política, a filosofia, a ciência” (MAINGUENEAU, 2013, p. 77).

Cabe-nos destacar ainda que, neste contexto, o poder das palavras deriva da adequação entre a função social do locutor e seu discurso: "o discurso não pode ter autoridade se não for pronunciado pela pessoa legitimada a pronunciá-lo em uma situação legítima, portanto, diante dos receptores legítimos" (AMOSSY, 2013, p. 12). É assim com todas as formas de discurso que circulam em uma sociedade - e não poderia ser diferente com as formações discursivas que transitam pela rede.

No caminho desenvolvido para a construção de dispositivos de interpretação dos discursos captados em nossa pesquisa, organizamos 18 categorias elencadas em três grupos temáticos que facilitassem a identificação de pistas e vestígios para a condução do processo de significação das falas dos nossos entrevistados. Tal posicionamento foi construído com base no que diz Orlandi (2012, p. 39):

As condições de produção, que constituem os discursos, funcionam de acordo com certos fatores. Um deles é o que chamamos relação de sentidos. Segundo essa noção, não há discurso que não se relacione com os outros. Em outras palavras, os sentidos resultam de relações: um discurso aponta para outros que o sustentam, assim como para dizeres futuros. Todo discurso é visto como um estado de um processo discursivo mais amplo, contínuo. Não há, desse modo, começo absoluto nem ponto final para o discurso. Um dizer tem relação com outros dizeres realizados, imaginados ou possíveis.

Ressaltamos, neste contexto, a conceituação de interatividade proposta por Bakhtin (1978) a partir da linguagem e sua condição constitutiva para a comunicação. Segundo o autor, todo signo procede de um consenso (com-sentir) entre indivíduos socialmente organizados, no transcorrer de um processo de interação que não deve ser dissociado da sua realidade material e das formas concretas da comunicação social. Ele cita que, "mergulhando ao fundo de si mesmo, o homem encontra os olhos do outro ou vê com os olhos do outro" 
(BAKHTIN, 1988, p. 328). O filósofo russo defende que a palavra age como uma ponte "entre mim e os outros". Ou seja, ela se apoia no enunciador, em uma extremidade, e no seu interlocutor, na outra. Para Bakhtin, interatividade não é elemento estratégico, mas algo constitutivo. De forma que o processo de comunicação só existe de fato porque há interação, ao mesmo tempo em que a linguagem irá se constituir como fato histórico, a partir do momento em que for movida pela interatividade e pela comunicação, em um processo dialógico. É por meio deste dialogismo que podemos repensar as práticas do jornalismo - inseridas na Comunicação Social - e, no âmbito das redes, considerar os novos instrumentos de colaboração e produção do conhecimento como um caminho possível para ampliar nossa ação sobre o mundo.

Ao analisarmos de maneira geral as categorias expressas nos enunciados de nossos entrevistados, captamos a possibilidade de delinear diferentes facetas para compor o perfil dos jovens jornalistas que produzem conteúdo em rede e estão ingressando no mercado de trabalho. A percepção positiva está relacionada à constatação de que existem iniciativas criativas - ainda que não em maioria - para o desenvolvimento de conteúdos e formatos inovadores por parte desses formandos e recém-formados que participaram da nossa pesquisa. Tal processo é permeado, quase que essencialmente, por interesses de satisfação pessoal. Isso vale, inclusive, para as raras manifestações de net-ativismo que são desenvolvidas por eles. Nos casos de blogs ou sites em que esse conceito está presente, todos manifestaram em seus discursos questões relacionadas a crenças, gostos e interesses pessoais para criar tais iniciativas. Ou seja, ainda que tenham formação como jornalistas, agem quase por prazer em rede, mas sempre com o interesse de se promoverem.

As ações realizadas na rede pelos integrantes da nossa amostra procuram ampliar as possibilidades de conectividade desses internautas. Nem sempre, contudo, isso se concretiza em ações interativas. Pelo que percebemos, a busca por notabilidade e exposição pessoal supera quaisquer outros interesses coletivos no cotidiano das redes. Tal notabilidade, por sua vez, está relacionada a ações empreendedoras e/ou voltadas ao aprimoramento de currículo, de maneira a permitir que esses jovens profissionais consigam captar recursos financeiros por meio de seus blogs, ou façam deles um bom portfólio para ser apresentado nos processos seletivos para uma vaga de emprego. No fim, todo o esforço visa a inserção no emprego formal.

Retomando o conceito de alteridade aqui exposto, fica claro que, muitas vezes, a necessidade de conexão está mais voltada à conquista de notabilidade do que propriamente à intenção de realização de desejos comuns. 
Porém, a condição que a sociedade contemporânea impõe, muitas vezes, obriga a aproximação entre os pares - algo que, em alguns momentos, acaba por beneficiar também a coletividade e os processos de avanço social. Este processo, por sua vez, exige que o interlocutor tenha capital cultural digital suficiente para agir e interagir em ambientes on-line e off-line simultaneamente, alcançando, assim, a autonomia que poderá permitir a construção de novas trajetórias no ambiente das redes.

Porém, a constituição de um perfil diferente de jornalista, criado a partir da exposição dos jovens que começam a se dedicar a essa carreira, reforça, ao mesmo tempo, a condição cíclica na qual a profissão se apoia, baseando-se em questões externas ao cotidiano das redações e empresas de comunicação que se desenvolvem continuamente em função de anunciantes e clientes, em lugar de dar prioridade a características centrais do jornalismo, como a informação, a investigação, a crítica ou a denúncia. Reduz-se, assim, por parte dos formandos e recém-formados, a visão romanceada da profissão que durante décadas aproximava o jornalista de um intelectual formador de opinião.

As mudanças percebidas no delineamento dos profissionais manifestadas por nossos entrevistados apontam também para um processo ainda não concluído sobre as novas facetas do jornalismo e do redirecionamento das práticas da profissão. Ao mesmo tempo em que verificamos sinalizadores de avanço ligados às possibilidades trazidas pelas redes - especialmente em relação à interatividade e à constituição de prossumidores -, há também um forte componente de manutenção do status quo, conferido pela necessidade de inserção em um mercado formal cada vez mais restrito, enquanto as opções empreendedoras ainda são construídas sob formatos que começam a ser testados.

Segundo Figaro (2013), o tempo e o espaço, comprimidos pelas possibilidades das tecnologias de comunicação e de informação, foram assimilados nos processos de produção de modo a reduzir o tempo para a reflexão, a apuração e a pesquisa no trabalho jornalístico. O espaço de trabalho encolheu e, ao mesmo tempo, diversificou-se, transformando as grandes redações em células de produção que podem ser instaladas em qualquer lugar com internet e computador. O jornalismo on-line, em tempo real, os blogs e as ferramentas das redes sociais são inovações nas rotinas profissionais.

A autora pontua que a reestruturação produtiva ocorrida no mundo do trabalho, principalmente a partir dos anos 1990, transformou as relações de trabalho. Foi a partir dessa década que aumentou o número de jornalistas contratados sem registro em carteira profissional, abrindo caminho para 
novas formas de contratação, como a terceirização, contratos de trabalho por tempo determinado, contrato de pessoa jurídica (PJ), cooperados e freelancers, entre outros. Ainda de acordo com Figaro (2013), a chamada "flexibilidade" acaba por transferir aos trabalhadores o peso das incertezas do mercado. Os freelancers trabalham em período integral, para vários lugares, sozinhos em casa. Começam a pensar como empreendedores, aplicam os conhecimentos do jornalismo em outras atividades, como na revisão de trabalhos acadêmicos ou até na venda de pacotes de assessoria de comunicação para políticos. Os mais jovens e os freelancers são os que menos conseguem planejar sua vida pessoal em relação à profissional fora do curto prazo, de acordo com a pesquisadora. Trabalham hoje para consumir hoje, e não sabem como será seu trabalho no ano seguinte. Imagino que isso cause grande parte do estresse na vida do indivíduo.

Ainda conforme Figaro (2013), é exigida hoje do jornalista atualização constante no uso de ferramentas digitais de prospecção, apuração e edição de informações. É fundamental ter habilidades e competências que permitam a atuação em diversas plataformas - impressa, tevê, rádio, internet - e em diferentes linguagens - verbal, escrita, sonora, fotográfica, audiovisual, hipertextual. São necessárias ainda noções de marketing e de administração, visto que se prioriza a visão de negócio/mercadoria já inserida no produto cultural, por meio do tratamento dado às pautas e à segmentação de públicos.

Ao relacionarmos o panorama exposto por Figaro às percepções por nós captadas a partir dos enunciados apresentados, vimos que é evidente - e também contraditória - a preocupação com a inserção neste espaço de trabalho precário ao mesmo tempo em que ganha força a busca pela notabilidade que, por sua vez, poderá eventualmente conferir aos que forem bem sucedidos nesta empreitada a chance de conquistar um emprego formal. Daí a grande preocupação com a construção e manutenção de network identificadas nas falas captadas em nossa pesquisa.

Tal condição, contudo, reforça a trajetória circular de boa parte das manifestações expressadas, no sentido de que os conteúdos produzidos em rede têm na própria rede sua principal inspiração. Ao mesmo tempo, tais conteúdos são também construídos para que seus enunciadores ganhem notabilidade no interior do mesmo espaço da rede. O capital cultural digital agiria no sentido de possibilitar que este círculo seja transformado em espiral, permitindo que o conhecimento avance em vez de se multiplicar sem sair do mesmo patamar. Desta forma, elementos que não se resumem às redes - como a educação formal e as mediações - teriam papel relevante 
para ampliar os olhares, que poderão se proliferar a partir de pontos de vista inovadores e interativos.

É neste contexto que pensamos em questões que aproximem a formação desses jovens ao desenvolvimento de capital cultural digital necessário para que se movam no mundo e ao conceito de prossumidor. Percebemos que, muitas vezes, sob a ótica da inserção no mundo do trabalho, o prossumidor nasce da necessidade e da proximidade. $\mathrm{O}$ que vemos na área da Comunicação - onde as vagas formais de trabalho são cada vez mais raras - é que a ação contínua dos recém-formados nas redes está mais diretamente relacionada à busca por um emprego do que às possibilidades empreendedoras que porventura também poderiam trazer retorno financeiro. É um cenário distinto do que se nota, por exemplo, entre graduandos de áreas técnicas, nas quais o mercado de trabalho é altamente demandante - o que traz aos formandos menor necessidade de incluir em seus processos de aprendizagem também o desenvolvimento de capacidades para se tornarem prossumidores.

Ocorre, porém, que as relações entre formação, trabalho e constituição de identidade se complexificam e se intensificam no contexto da cibercultura e na cultura da convergência, conforme apontado por Jenkins (2008). O cidadão passa a ter a possibilidade de não apenas produzir sentido e identidade, mas também de elaborar produtos culturais, de entretenimento, informações, ideias e projetos, posturas políticas ou engajamentos. Enfim, ser um produtor ativo de bens para consumo.

Dentro dessa perspectiva de uma cultura de convergência, diversas experiências culturais mostram as potencialidades desse novo processo de comunicação e produção de sentidos. Segundo Santaella (2007), o ciberespaço favorece, ao mesmo tempo, a emergência de práticas de autoformação. Mas o equilíbrio entre a difusão indiscriminada da informação e a construção individualizada do conhecimento é muito instável. Por permitir um tipo de aprendizado aberto, que pode ser obtido em quaisquer circunstâncias, a era da mobilidade inaugurou esse fenômeno inteiramente novo: a aprendizagem ubíqua (SANTAELLA, 2007). E ela não se confunde com nenhuma forma de aprendizagem existente até hoje, nem com a e-learning, que se pode traduzir por aprendizagem em ambientes virtuais. Embora tenha parentesco, também não se confunde com o que vem sendo chamado de m-learning, ou seja, aprendizagem móvel. Assim, o consumidor de informação não deixa de produzir também, conforme aponta Lévy (1996, p. 63): “o consumidor não apenas se torna coprodutor da informação que consome, mas é também produtor cooperativo dos 'mundos virtuais' nos quais evolui”. 
A "sociedade da ubiquidade" envolve um uso expressivo das comunicações digitais móveis para garantir o acesso de qualquer pessoa, em qualquer momento e em qualquer lugar a uma ampla gama de informações (SANTAELLA, 2007). A educação também sofre essas consequências, configurando-se em uma "educação móvel", em que toda pessoa pode acessar os recursos de aprendizagem e que promovem, dessa forma, mudanças profundas, não só na educação, mas também nas instituições educativas. Essas mudanças na aprendizagem ocasionam a alfabetização digital que resultam na "transformação de ordinários cibernautas em prossumidores”, conforme Santaella (2007).

Os desafios da educação diante das mídias e dos processos de comunicação que permeiam quase todos os momentos de nosso cotidiano traçam novas perspectivas educacionais e comunicacionais para compreensão do cenário social contemporâneo. A discussão sobre o significado da mudança da condição comunicativa, identificada a partir do movimento dos receptores agirem também como emissores da comunicação, aponta para a compreensão de como se dá a formação de sujeitos capazes de se mover na atual condição imposta pela sociedade midiática na qual vivemos. É neste contexto que ganha escala, rapidamente, a necessidade de a educação se envolver na formação de receptores-atores, ou prossumidores, aptos a interagirem com as mídias atuais. A personalização da comunicação em pequenas telas que levamos conosco - que nos permitem novas possibilidades, novas convergências - coloca-nos diante de uma também nova condição comunicativa, que modifica nossa maneira de ser e de estar no mundo. Mais do que isso, a configuração das novas mídias e da convergência midiática que se desenha, enquanto agentes socializadores, pede a participação desses prossumidores.

É diante dessa perspectiva que se dá a discussão sobre a figura do prossumidor, preliminarmente definido como a junção entre uma pessoa que consome, mas que também produz conteúdo. Eles refletem e estimulam mercados através de sua participação e poder de comunicação. Muitas vezes são os prossumidores os principais responsáveis pela inovação de produtos, num sentido mais restrito, e pela produção de cultura de consumo, num sentido mais amplo. No caso do presente artigo, a ideia envolve trazer as discussões acerca dos prossumidores e sua relação com o contexto formativo dos graduandos, em especial na área de Comunicação.

Alvin Toffler foi quem primeiro se referiu à expressão prossumidor, ainda em 1980. Apesar da abordagem essencialmente mercadológica, o termo tem trazido avaliações e reflexões de teóricos do campo da Comunicação. 
Trata-se de estabelecer um deslocamento do consumidor para a lógica da produção, graças ao seu acesso e domínio das novas tecnologias (OROFINO, 2011) para se referir a quem consome e produz conteúdo - algo que ganharia destaque no momento atual, em que o consumo priorizaria a troca de informações em detrimento de produtos materiais/físicos (TOFFLER, 1980). Adotamos aqui o termo traduzido de prosumer para o português, prossumidor, com duas letras “s”, como no caso de João Távora, responsável pela tradução do livro de Alvin Toffler (1980).

De acordo com Orofino (2011), do ponto de vista de "uma cultura simbólica, as reflexões sobre produção de sentidos por parte do público receptor possuem uma trajetória muito mais ampla que o conceito em questão"; contudo, o que é fundamental, prossegue a autora, é a compreensão de que essa nova configuração permite o "acesso às materialidades e à socialização dos meios tecnológicos de produção” (OROFINO, 2011, p. 187). Esse contexto permite que os sujeitos passem a ter acesso aos meios de produção e passem eles próprios a produzirem bens para consumo.

Toffler (1980) afirma que

muitos dos mesmos dispositivos eletrônicos que usaremos em casa para fazer trabalho remunerado também tornarão possível produzir mercadorias ou serviços para nosso próprio uso. Neste sistema o prossumidor, que dominou as sociedades da Primeira Onda, será trazido de volta ao centro da ação econômica - mas numa Terceira Onda, em base de tecnologia.

O prossumidor assumiria comportamento distinto daquele que se observa na maioria dos usuários da internet, destacando-se a forma com que ele se relaciona com o conhecimento e como ele colabora em rede. Sua capacidade de buscar respostas representa uma evidência do modo independente a partir do qual ele se relaciona com as informações, pois deixa de ser um usuário passivo, passa a ser um consumidor crítico que, além de posicionar-se diante de irregularidades percebidas, denuncia e evidencia as questões éticas envolvidas em práticas inescrupulosas, por exemplo.

Há, porém, quem observe com bastante cautela todas essas possibilidades otimistas trazidas pela tecnologia para a atuação dos internautas diante das tendências de desenvolvimento do conteúdo colaborativo. Segundo Fuchs (2011), por exemplo, é possível considerar como uma ideologia a "cultura participativa" ensejada pelas novas tecnologias e pelo desempenho de papéis como o do prossumidor. Para Fuchs (2011), o prossumidor não é um indivíduo isolado no mundo e a sua capacidade de realmente "ser ouvido" 
depende, em alguma medida, das lutas de classes, que são midiatizadas. A noção de classe precisa ser expandida para incluir todo mundo que cria e recria espaços de experiência comum, como o conteúdo gerado pelos usuários na internet, por meio de suas práticas. Compreender a internet hoje, portanto, significa entendê-la também na chave da luta de classes, da exploração e do trabalho digital. Não se trata, contudo, de negar a questão da criatividade e da participação, mas de ampliar o olhar para observar todos esses fatores conjuntamente. Mas ocorre que, com essas mudanças, a comoditização dos usuários da internet também ganha uma face mais complexa, havendo uma "total comoditização da criatividade humana". O usuário é, em sua visão, "por si só uma mercadoria, e através desta mercantilização sua consciência torna-se permanentemente exposta à lógica da mercadoria enquanto ele está on-line sob a forma de publicidade" (FUCHS, 2012, p. 712).

Na nossa pesquisa, pudemos chegar à conclusão que - em razão do embaralhamento dos fatores que compõem a sociedade contemporânea tem se mostrado também cada vez mais nebulosa a compreensão de questões relacionadas ao uso de mídias e tecnologias, especialmente no que se refere à educação. Nesse sentido, nossa pesquisa constatou, afinal, uma redução no papel da mediação socioeconômica na configuração de alguns processos de formação, além de um aumento da participação de outros valores, como a necessidade de estar ininterruptamente conectado, para que sejam ampliadas as possibilidades de desenvolvimento de carreira dos jornalistas que começam a ter contato com o mercado de trabalho. Porém, pensando no que propõe Fuchs (2012), dentro da lógica da comoditização do usuário, há que se considerar que o usuário nas redes sociais exerceria um trabalho não-pago ao fornecer, espontaneamente, seus gostos pessoais e ao criar, compartilhar e curtir os conteúdos mais diversos. Fuchs (2012) considera que empresas envolvidas com redes sociais exploram os usuários ao incentivar o engajamento em atividades dos prossumidores. E aqui nos caberia perguntar se aquela imagem de autopromoção demonstrada por nossos entrevistados em rede não se opõe completamente ao papel que acabam por exercer, de referendar essa estratégia empresarial, ainda que o façam por estarem em busca de novas alternativas de atuação no complexo e precário mercado de trabalho do jornalismo que se configura atualmente. 


\section{Referências}

AMOSSY, R. (org.). Imagens de si no discurso - a construção do ethos. São Paulo: Contexto, 2013.

BREDARIOLI, C. Processos educativos e formação de jornalistas: redirecionamento das práticas profissionais a partir das possibilidades interativas das redes digitais. Tese (Doutorado). São Paulo: ECA-USP, 2014a.

Construção de capital cultural digital a partir das possibilidades interativas das redes. In: XXXVII Congresso Brasileiro de Ciências da Comunicação, Foz do Iguaçu, PR, Anais Intercom, 2014b.

BAKHTIN, M. Marxismo e filosofia da linguagem. São Paulo: Hucitec, 1988.

BOURDIEU, P. A distinção: crítica social do julgamento. São Paulo: Edusp, 2008.

Los tres estados del capital cultural. Disponível em: http://sociologiac. net/biblio/Bourdieu-LosTresEstadosdelCapitalCultural.pdf>. Argentina, 1998.

O poder simbólico. Rio de Janeiro: Bertrand Brasil, 2005.

CASTELLS, M. Redes de indignação e esperança: movimentos sociais na era da internet. Rio de Janeiro: Zahar, 2013.

FIGARO, R (org.). As mudanças no mundo do trabalho dos jornalistas. São Paulo: Atlas, 2013 .

FREIRE, P. Extensão ou comunicação?. 15ª ed. São Paulo: Paz e Terra, 2011.

FUCHS, C. Foundations of critical media and information studies. New York: Routledge, 2011.

Dallas smythe today - the audience commodity, the digital labour debate, marxist political economy and critical theory: prolegomena to a digital labour theory of value. Triple C, 10, 2, 692-740, 2012.

JENKINS, H. Cultura da convergência. São Paulo: Aleph, 2008.

LÉVY, P. A inteligência coletiva. São Paulo: Loyola, 1996. 
MAINGUENEAU, D. Ethos, cenografia, incorporação. In: AMOSSY, Ruth (org.). Imagens de si no discurso - a construção do ethos. São Paulo: Contexto, 2013.

ORLANDI, E. Análise de discurso. Campinas, SP: Pontes Editores, 2012.

OROFINO, I. Recepção e resposta: As webséries como índice para se pensar a emergência do prossumidor. In: CARRASCOZA, J. A.; ROCHA, R. de M. (orgs). Consumo midiático e culturas da convergência. São Paulo: Miró Editorial, 2011.

PRENSKY, M. Digital natives, digital immigrants. On the Horizon. Stamford: NCB University Press, Vol. 9 No. 5, Outubro 2001.

RECUERO, R. Redes sociais na internet. Porto Alegre: Sulina, 2009.

SANTAELLA, L. Linguagens líquidas na era da mobilidade. São Paulo: Paulus, 2007.

TOFFLER, A. A terceira onda. Rio de Janeiro: Record, 1980. 
no exercício de tentar desenvolver uma pedagogia “crítica”, na busca de um olhar ativo para a mídia que nos invade. Mas não no sentido de desenvolver técnicas de leitura estética para analisar as imagens que são veiculadas na mídia diariamente. É preciso estar atento para a complexa rede de relações e representações que as fotografias produzidas e veiculadas na mídia carregam. A partir daí, talvez seja possível iniciar os contornos de uma discussão sobre como estas imagens midiáticas operam na produção de representações e na constituição de nossas identidades como estudantes, professores, professoras e comunidade. Neste período contemporâneo em que as reflexões pós-modernas trazem à tona o questionamento dos limites e da gênese das certezas universais e imutáveis, é preciso também entender a mídia como aliada para uma nova compreensão, percebendo-a como um espaço de educação, criando temas escolares, produzindo subjetividades e identidades.

A proposta de levar a discussão da mídia e da cultura das imagens, associada à cultura do consumo para a escola, encontra, no uso das câmeras fotográficas, apoio para o desenvolvimento de uma alfabetização das imagens. Esse trabalho desenvolvido na interface da Comunicação e Educação resulta da troca de saberes entre o conhecimento dos acadêmicos e as experiências dos alunos, professores e comunidade. É o encontro entre a escola pública e a universidade. É nesse espaço que o acadêmico de Comunicação Social tem a oportunidade de colocar em prática os conteúdos vistos em sala de aula, além de expandir seus conhecimentos nos trabalhos produzidos. As câmeras fotográficas tornaram-se aliadas no processo de aprendizagem e, mediante a compreensão de suas técnicas, é possível estabelecer a comunicação visual, ou seja, os alunos começaram a redescobrir o bairro onde vivem. $\mathrm{O}$ uso da fotografia como uma prática educativa é algo que vem se intensificando com o tempo, e acredita-se que a utilização da imagem dentro das salas de aula possa ser cada vez mais compreendida como mais uma possibilidade para a produção e aquisição do conhecimento. $\mathrm{O}$ artigo aponta a pertinência de pensarmos acerca da linguagem utilizada pelos artefatos culturais que nos interpelam todos os dias. Nas palavras de Fischer (1999, p. 29), ressaltamos a importância desta aproximação entre escola e mídia:

enquanto a escola ficar no papel tímido de espectadora ressentida de uma sociedade que se pauta pelo mercado e pelas imagens de sucesso individual, de culto narcísico do corpo, de ilusão de felicidade dada pelo consumo real e imaginário, estará apenas marcando seu lugar como ausente do seu tempo. 
Partindo da necessidade de problematizar a relação escola cultura midiática, o estudo aponta a educação como um terreno com fronteiras de difícil demarcação, especialmente ao considerarmos o caráter produtivo da mídia. A proposta é trazer para a discussão práticas pedagógicas como o uso da fotografia na escola. Na medida em que trazemos a fotografia como suporte de análise, criamos trabalhos específicos que intensificam, nos estudantes, suas competências interpretativas, bem como a produção e análise das imagens, estabelecendo-se comparações a partir dos conteúdos vistos. É nesse sentido que esta experiência busca introduzir a fotografia nas aulas do ensino fundamental como uma maneira de despertar nos alunos o interesse em aprender e relacionar os conteúdos de aula, os ensinamentos da mídia e o contexto local:

O trabalho com imagens tem grandes implicações cognitivas: aumenta a intensidade do olhar, mas também a qualidade da imaginação, reveladora da realidade semi-imaginária do homem. A descoberta do significado da imagem não existe independente do espectador e a cautelosa tarefa do professor consiste em não impor interpretações, mas em favorecer comparações e diálogos (LEITE, 1996, p. 83).

As imagens apresentam-nos um convite ao conhecimento. Assim, pode-se dizer que a fotografia é uma importante ferramenta de estudo, na qual podemos encontrar traços culturais e históricos de nossas sociedades. Cabe esclarecer que as experiências analisadas neste estudo integram um projeto de extensão que, desde $2002^{5}$, vem discutindo os ensinamentos midiáticos com as escolas públicas. As oficinas de Mídia e Educação foram criadas com a proposta de ampliar a visão dos alunos sobre o bairro onde vivem. Além de aprender as técnicas fotográficas, as crianças e jovens são incentivados a valorizar o seu bairro e o lugar em que moram. Em mais de uma década de trabalho, foram desenvolvidas diferentes experiências que oportunizaram que alunos da rede pública revelassem novos ângulos do seu bairro. Uma delas foi o projeto Imagens do São José, quando estudantes das escolas produziram fanzines com fotos e entrevistas feitas com moradores do bairro. No segundo ano, foram impressos cartões postais a partir da escolha da comunidade, por meio do voto popular, das imagens que deveriam representar

5 Projeto de extensão universitária Nosso Bairro em Pauta, desenvolvido em parceria com a pesquisa institucional na Universidade Feevale. Uma descrição mais detalhada desta experiência em Brum e Schmidt, 2014. Ver referências. 
o bairro. Outra experiência foi o resgate da história do bairro a partir do olhar das crianças e jovens, que produziram uma mostra fotográfica. Ainda outra iniciativa foi a mostra Hortas Urbanas, momento em que a equipe percorreu pequenas hortas produzidas pelos moradores e fez o registro fotográfico. No ano seguinte, foi a vez de percorrer o bairro para fotografar a matemática que está em cada esquina, em cada casa, em cada calçada. No último ano, a partir da arte dos retratos, os alunos fotografaram os colegas e os moradores do bairro. Para este artigo, o foco foi descrever e analisar as experiências da relação da fotografia com a matemática e com a produção de retratos. O que pretendemos não foi lançar uma "fórmula" ou uma estratégia mais perspicaz para analisar as fotografias. O objetivo é colocar em discussão as narrativas que as fotografias estão criando e colocando em circulação sobre o bairro, a escola e a comunidade (BRUM; SCHMIDT, 2014).

\section{Matemática urbana}

Estudar a matemática por meio da fotografia oportunizou que os alunos fossem os próprios produtores de seu conhecimento. $\mathrm{O}$ processo de ensino-aprendizagem envolveu o ato de fotografar a partir dos conhecimentos adquiridos em sala de aula; com as imagens, criavam-se diálogos, que emergiram como momentos de estudo. Mediante a produção das imagens, a professora conseguia estabelecer comparações com aquilo que é descrito em palavras sobre a "realidade" capturada pelos alunos. A fotografia mostrou-se como uma ferramenta para que os jovens desenvolvessem uma visão própria sobre seu bairro, sua realidade. A partir das contribuições da Fotoetnografia, a experiência foi denominada de Fotografia e Matemática Urbana. Dessa forma, o olhar da antropologia ajudou a construir esta proposta e a evidenciar a importância do domínio da técnica fotográfica para que os jovens das oficinas pudessem registrar o seu cotidiano: "sendo a fotografia um permanente ato de recortar e enquadrar elementos da realidade num plano - duas dimensões - se faz necessário um domínio técnico específico que venha a explicar os recortes desejados" (ACHUTTI, 1997, p. 64). O autor lembra que o domínio técnico da câmera fotográfica é essencial para construirmos uma narrativa por meio de imagens e pode ser utilizado como ferramenta em estudos etnográficos. Nas primeiras oficinas, os alunos aprenderam a parte técnica da fotografia para que, nas oficinas seguintes, pudessem ter início as saídas de campo. No primeiro passeio com as câmeras fotográficas pelo 
bairro, os alunos tinham como tarefa fotografar o que era matemática para eles. Foi observado que, neste primeiro momento, os alunos clicavam antes mesmo de pensar ou planejar o propósito de suas fotografias. Esse contexto é discutido por Jobim (2002, p. 63) em seus estudos sobre a discussão da pedagogia das imagens:

A experiência atual com as imagens, quer sejam fotográficas, cinematográficas ou televisivas, acontece na maioria das vezes de forma espontânea, intermitente, fragmentada, enfim, de modo superficial. Com a proliferação das imagens a cada dia elas perdem mais a capacidade de dizer algo a alguém, pois também as pessoas que vivem essa dispersão perceptiva de modo permanente acabam por perder a sensibilidade de ver as coisas.

O encontro seguinte aconteceu na Universidade Feevale. Inicialmente, foi apresentado o vídeo Geometria do Cotidiano; em seguida, foi realizada uma análise coletiva das fotos da última oficina, com o intuito de ajudar os alunos a identificar os elementos matemáticos encontrados no meio social. Nessa avaliação, cada aluno teve que compartilhar com a turma o resultado de suas fotos. Os alunos foram desafiados a descrever a mensagem de sua fotografia a partir das questões técnicas que aprenderam na oficina anterior. O objetivo desse encontro foi analisar a narrativa presente nas fotografias e as leituras ou interpretações que podem ocorrer quando começamos a estabelecer a educação do olhar. Leite (1996, p. 84) lembra-nos de que, dentro da pedagogia das imagens, há a base histórica e técnica da fotografia, essenciais para a leitura das fotografias:

A forma e o conteúdo estão associados na linguagem visual. Isso implica em dois elementos decisivos para a leitura da imagem. Uma base técnica e doses de criação artística. Para a leitura da fotografia, é preciso que se tenham noções de história da técnica fotográfica, assim como na iconografia, lições de pintura e litografia, que permitiram fixar e difundir as imagens de modo de vida que se suponham destinados a desaparecer.

Essas reflexões, além de apontar possibilidades de se analisar uma imagem, contribuíram para retomar os conteúdos ensinados na oficina, que serviam de sustentação para análise das fotografias. Ao mesmo tempo em que os alunos analisavam as imagens, percebiam que a aprendizagem da matemática não se limita ao racionalismo de números ditos exatos, mas também está relacionada com o nosso cotidiano e a nossa cultura. A partir 
dessa oficina, os alunos começaram a enxergar a matemática no seu bairro e a relacioná-la com as formas geométricas. Com a descoberta da geometria viva no bairro, os alunos voltaram seus olhares na busca de três elementos importantes na matemática: quadrado, triângulo e círculo. Mais uma vez, perceberam e ficaram surpresos com o quanto a matemática e suas múltiplas formas estão presentes no nosso dia a dia. As formas geométricas foram observadas em construções, placas e anúncios, entre outros tantos lugares. Aqui surge a oportunidade de problematizar com o grupo a construção de nosso olhar quando somos subjetivados pela mídia todos os dias. As crianças clicaram as formas, respeitando as orientações técnicas, que são fundamentais na construção de uma narrativa por imagens. É nesse sentido que Achutti (1997, p. 78) nos ajuda a refletir sobre a importância de apropriarmo-nos tecnicamente de ferramentas para discutir a relação imagem, mídia e cultura: "hoje se procura pensar a imagem fotográfica como veículo, como meio eficaz de ajudar a fluírem idéias, sensações, discursos, com os mais diversos propósitos, que vão desde a publicidade à antropologia”.

Considerando-se a importância de discutir a fotografia como instrumento de comunicação, tornou-se essencial que, dentro da proposta da oficina, os alunos compreendessem o papel da publicidade e como ela utiliza as imagens para construção e multiplicação de suas mensagens. Com o intuito de mostrar aos alunos as possibilidades de manipulação da imagem, o grupo foi levado para o estúdio fotográfico da Universidade, onde puderam compreender os processos de uma produção fotográfica publicitária. O grupo levou de casa objetos que remetessem às formas geométricas para serem fotografados com toda a aplicação da técnica, e foram desmistificadas as diferentes possibilidades de iluminação dentro de um estúdio. Foi uma oportunidade de discutir a potência da publicidade para construir uma forma hegemônica de olharmos para as relações na atual sociedade de consumidores. A produção fotográfica requer vários elementos técnicos para apresentar uma ideia, um conceito no seu processo de significação. Nas atividades dentro do estúdio, os alunos puderam trabalhar com diferentes tipos de iluminação, com o propósito de entender esse processo.

Aqui cabe lembrar que, em uma das oficinas no estúdio, os alunos trabalharam em grupos e criaram com o corpo as formas geométricas para serem fotografadas. O propósito dessa oficina era mostrar aos alunos que o corpo também é um elemento visual muito utilizado nas fotografias publicitárias. Os estudos de Garcia (2007, p. 1) sobre a relação da imagem do corpo com a linguagem fotográfica colaboraram para ressignificar e ampliar esta possibilidade: 
Quando o corpo em cena se espetaculariza, basta atinar os relevos que abraçam as linhas e contornam dorsos, pernas, braços, lábios. Há uma mensagem que fica impregnada de subjetividade com a força imanente do corpo que dita o mundo, sobretudo hoje. Da poética à estética, a impressão visual do corpo é resgatada pelo registro fotográfico. Diante do ato fotográfico, a imagem corpórea equaciona a vivacidade humana e potencializa um resultado.

A união da matemática com a fotografia não foi apenas um modo de realizar o estudo das formas geométricas. A descoberta da geometria no cotidiano serviu para que os alunos tivessem uma maior aproximação com o bairro onde vivem. Ao observarem-se os elementos geométricos, consequentemente, observava-se o bairro. $\mathrm{O}$ foco nos pequenos detalhes propiciou a redescoberta do local onde os alunos moram, possibilitando uma valorização do bairro. O uso das câmeras fotográficas serviu como suporte para a observação e a compreensão das narrativas fotográficas a partir da educação do olhar. Esse exercício contribuiu para a formação dos jovens, colocando-os como consumidores críticos da mídia que nos cerca. Acredita-se que a fotografia se mostrou eficaz no processo metodológico, demonstrando à comunidade escolar maneiras criativas para o ensino. Para os acadêmicos de Comunicação, foi um desafio repensar o status pedagógico da mídia que nos interpela todos os dias.

\section{Retratos da nossa gente}

Em outra experiência, com outra turma da mesma escola pública, após a apropriação técnica da fotografia, iniciou-se a produção dos retratos, que foi dividida em dois momentos. O primeiro foi a produção dos retratos dos alunos, que também são moradores do bairro e ajudam a construir sua história. Além disso, a proposta era mostrar para os alunos outras possibilidades da fotografia, maneiras diferentes de se produzir uma imagem, nas quais os flashes passam a exercer papel principal. Com a possibilidade de se construir uma iluminação artificial, obtém-se um maior controle e precisão na estética que se deseja na fotografia. Segundo Guran (1992, p.35), "fotografia é luz, e, por conseguinte, sombra é o que dá volume e profundidade plástica a uma imagem. A intensidade, o tipo e a direção da luz são fatores determinantes para o resultado de uma foto". Com isso em vista, os alunos foram levados para o estúdio fotográfico da Universidade para que pudessem compreender esses processos e ter uma nova experiência ao trabalharem com esses recursos. 
Para exercitarem os tipos de iluminação que aprenderam, foram formadas duplas, e cada aluno deveria fazer um retrato do colega. Foram montados dois sets: um que possibilitasse a luz dura (iluminação Low-Key) e outro com a suave (iluminação High-Key). Assim, os alunos puderam ver as diferenças com a própria foto que produziram. Os alunos conseguiram perceber, ainda, algumas funções, tais como: abertura do diafragma, velocidade do obturador e o ISO, configurações essenciais para uma boa exposição e, no caso de alguns retratos, conseguir o movimento congelado. Conforme Hurter (2011, p. 99),

uma fotografia é somente uma representação bidimensional, de uma realidade tridimensional, por isso, o objetivo do fotografo é produzir um retrato que mostre a circunferência e a forma do rosto humano. Isso é feito primeiramente com destaques (áreas que são iluminadas com fontes de luz) e sombras (áreas que não são). Assim como um escultor modela a argila para criar a ilusão de profundidade, a luz modela a forma do rosto para dar-lhe profundidade e forma.

Após a experiência dos retratos no estúdio, foi iniciada a segunda etapa, que era produzir retratos dos moradores do bairro. O desafio da produção dos retratos mostrou-se uma possibilidade de promover novos olhares para o local onde os estudantes vivem. As saídas contribuíram para um olhar mais engajado com a sua comunidade. Durante semanas, foram fotografados moradores, comerciantes, artesãos, estudantes, entre tantas pessoas que constituem o cenário do bairro Vila Nova. Em cada retrato emergia uma nova história, um novo jeito, uma nova personalidade, características percebidas diferentemente por cada criança, com seu olhar e as noções estéticas aprendidas na oficina. Conforme Hurter (2011, p. 19), "um bom retrato fornece informações a respeito do 'eu' da pessoa. Através da iluminação controlada, da pose e da composição, o fotógrafo se empenha ao máximo para capturar a essência do modelo, de uma só vez registrando sua personalidade".

A união dos retratos ao planejamento contribuiu significativamente para ampliar a proposta, porque fotografar os moradores pode ser considerado uma via de mão dupla. Em outras palavras, ao mesmo tempo em que foram descobertas pessoas do bairro, eram revelados outros ângulos do bairro e novas possibilidades de enxergá-lo.

Há mais de quinhentos anos que os estudos do homem vivem sob a hegemonia da verbalidade, da escrita em especial. Não tenho certeza que os filhos de nossos filhos saberão ler e escrever como sabemos fazê-lo. Eu sei, desde já, que o adolescente informatizado não olha o mundo da mesma maneira que eu o descobria há quarenta anos. Uma coisa 
é certa: os homens de amanhã enunciarão e organizá-lo-ão a partir de outros parâmetros lógicos, gerados pelos novos suportes comunicacionais que continuarão esculpindo (SAMAIN, 1995, p. 9).

Temos aqui a oportunidade de problematizar com o grupo a construção do nosso olhar quando somos subjetivados pela mídia todos os dias. As crianças produziram os retratos, respeitando as orientações técnicas fundamentais na construção de uma narrativa por imagens. A seguir, compartilhamos o depoimento de algumas crianças sobre a experiência com os retratos:

Eu cuidava [d]o fundo da foto para ser um lugar bonito e a foto ficar mais bonita. Eu gostei de passear pelo bairro, eu nunca tinha feito isso, foi legal. Eu fotografei minha vó, estava ali no xis do meu tio, porque estava pegando fritas, daí eu encontrei ela, e a professora disse que podia tirar uma foto dela. Fiz a foto da cintura para cima e cuidei [d]o fundo. Ela disse que achou bem legal (Aluno A).

O que mais gostei foi tirar fotos dos moradores, porque a gente tirou fotos de um monte [de] pessoas que eu conheço. Eu lembro que a gente foi lá em casa fotografar minha vó, foi legal e fiquei envergonhado, até ela ficou, mas fez a foto. Eu cuidei para a câmera não ficar balançado, não mexer as mãos, para ficar certinha a foto. Fiz ela da cintura para cima. Achei legal entrar no estúdio de fotografia. A gente tirou um monte de fotos lá dentro. A gente usou tipo um guarda-chuva e um painel branco, pode deixar as fotos mais claras e escolher o tom (Aluno B).

A gente aprendeu a tirar fotos no plano americano, só rosto e enfeite. Essa parte eu gostei, porque a gente aprendeu mais sobre fotografia, e podemos usar isso em outros lugares, como no casamento da minha dinda. Eu gostava de fotografar o enfeite, porque a gente vê uma coisa de bonito que a pessoa tem. A oficina, além de ajudar minha vida, me fez aprender novas coisas além de só ficar na escola. Cada foto no estúdio tinha uma coisa sobre um significado diferente. A luz mais escura foi [a] que mais gostei, me dava um pouco de medo, e na mais clara me sentia livre. Quando nós íamos fotografar os moradores, eles pediam para se arrumar, e, na hora de fotografar, eu me preocupava com os detalhes que eles tinham (Aluno C).

Os depoimentos das crianças sobre a experiência na produção dos retratos dos colegas e dos moradores demonstram a importância de investir em projetos que levem a fotografia para o contexto escolar. Da mesma forma, os depoimentos dos moradores do bairro sobre a experiência de terem sido retratados pelas crianças expressam a produtividade do encontro de gerações por meio da fotografia. Uma oportunidade para a troca de saberes e a valorização do conhecimento, da experiência dos moradores do bairro: 
Desde criança, eu gostava de flores, sempre gostei. Um dia desses, pensei assim para mim: ah, eu vou vender flores, porque daí plantava e vendia. Comprei minhas primeiras mudinhas em Porto Alegre, onde minha amiga Clarisse comprava. Tinha muitas flores, e fiquei buscando lá por 15 anos. Moro há 53 anos no bairro, e meu marido, há 73. O dia em que as crianças vieram aqui, eu mostrei para elas as flores, e elas escolheram algumas para eu segurar na janela. Foi bem legal, foi bom as crianças terem vindo aqui. Elas já vinham antes, às vezes, quando eu estava de aniversário, vinham cantar parabéns para mim, só que elas queriam torta, mas eu não tinha feito ainda. Me senti bem em ser fotografada pelas crianças, meio envergonhada. Eu queria ter me arrumado, mas não cheguei a me arrumar, fiquei como eu estava. Sempre é bom mostrar alguma coisa do bairro (Moradora do Bairro, 72 anos).

Eu gosto de crianças e dessas atividades. Sou moradora do bairro há 42 anos, minha filha tinha 18 anos quando vim morar aqui. No início, as ruas eram cheias de valos e barro, não se tinha asfalto. Onde é a Feevale hoje, era só mato. Tinha também o campo do Vila Nova, que hoje não existe mais. No dia da foto, eu estava sentada na frente de casa, e alguém me chamou, então entrou aquela turminha de crianças pelo portão. Nós conversamos, as crianças conversaram. Tinha umas três crianças paradas perto de mim que me posicionaram e fizeram a foto. Eu fiquei contente naquele dia, muito feliz pelas crianças terem vindo à minha casa. Achei bacana e fiquei pensando quantos moradores vão fazer isso nas suas casas. Bonito eles quererem conhecer a história dos moradores, assim as coisas não ficam paradas (Moradora do bairro, 80 anos).

\section{Outro depoimento é da professora responsável pela turma e con-} tribui para registrar o envolvimento que os alunos tiveram com a oficina e a importância da discussão da mídia, da fotografia e das vivências na comunidade como práticas de ensino:

O dia da oficina era lembrado pela turma no dia anterior, portanto, era um momento muito esperado. O linguajar mais técnico da fotografia em si passou a fazer parte das conversas das aulas, onde exemplificavam os conteúdos desenvolvidos em aula com o mesmo. Passei a perceber uma maior preocupação e cuidado com o bairro em si. As crianças começaram a ver os "detalhes" do mesmo, assim como foram levadas levados a ver os detalhes nos moradores ao fotografá-los. Com isso, se tornaram mais críticas, trazendo a vivência das saídas, caminhadas e conversas com os moradores nos diferentes assuntos discutidos nos momentos de sala de aula. As caminhadas pela comunidade trouxeram um olhar sobre os colegas e, consequentemente, um entendimento sobre diferentes pontos. Entrar no estúdio, presenciar todos os equipamentos serem montados e ajeitados para que eles fossem fotografar os encantou. Queriam saber para que cada equipamento servia e quando [os] usariam. Depois, ficaram maravilhados ao verem suas produções (Professora A). 
O desenvolvimento dessa experiência oportunizou a construção de um novo olhar para a comunidade. Foi por intermédio dos retratos dos moradores que os alunos ampliaram a possibilidade de lidar com essa proliferação fotográfica em que vivemos e que está operante na cultura visual associada à cultura do consumo. A imagem passa a não ter sentido se não é compreendida, e é aí que as regras comunicacionais advindas dos suportes de produção fotográfica nos alfabetizam para a leitura das imagens. A partir desse trabalho, os jovens estão desenvolvendo possibilidades de uma nova leitura da mídia, ampliando a compreensão de seu processo de construção. A educação estética, mediante a técnica fotográfica, sendo a fotografia um dos principais produtos da cultura midiática na contemporaneidade, propiciou a leitura de imagens e a redescoberta de seus ângulos e enquadramentos para sua realidade. Quando nos voltamos para uma fotografia, observamos um recorte do tempo.

\section{Considerações}

A partir deste trabalho, os jovens estão desenvolvendo possibilidades de uma nova leitura da mídia e ampliando a compreensão de seu processo de construção. Antes de finalizar, consideramos importante compartilhar alguns dos depoimentos de alunos e professoras envolvidas no projeto. $\mathrm{O}$ primeiro depoimento demonstra o significado que teve o projeto para esse grupo de jovens da rede pública. O segundo e o terceiro depoimento são das professoras responsáveis pelas turmas e registram o quanto o trabalho contribuiu para que os alunos fossem efetivamente agentes da construção de seu conhecimento:

Trouxemos objetos de casa, então, com isso, trabalhamos a percepção de formas geométricas que encontramos em nossa casa e que não percebíamos antes. A sensação de pegar uma máquina profissional na mão é ótima, aquela sensação de empolgação nos faz querer aprender mais e mais. Achei muito legal termos saído para fotografar formas geométricas no bairro, pois saímos da escola, mas mesmo assim continuávamos a aprender. Agora eu vejo e percebo mais as formas geométricas (Aluna D).

Aliar a fotografia à matemática foi uma experiência que permitiu aos alunos serem mais ativos nas aulas, serem mais responsáveis pela construção do seu conhecimento. A sala de aula passou a ser as ruas do bairro, num ambiente amplo, livre, deixar o aluno explorar os conhecimentos, construir novos saberes através do olhar das lentes de uma máquina fotográfica, a matemática num contexto vivo (Professora B). 
Foi muito bom realizar esta atividade dos retratos, trouxe um "tempero" especial às aulas. Ainda mais esta, que trabalhou tanto o novo (fotografia) quanto o conhecido (a sua comunidade e as pessoas que nela vivem: seus amigos, vizinhos, ex-alunos da sua escola, familiares). Este momento foi muito importante para eles, pois eram eles que nos conduziam pelas ruas da comunidade: espaço deles (Professora A).

É preciso destacar que o resultado deste trabalho serviu de significativo aprendizado, sobretudo para os acadêmicos de Comunicação envolvidos na construção da proposta. Além de contribuir na formação acadêmica, traz um impacto de forma peculiar, pois reforça a importância da experiência da extensão aliada à pesquisa na área da Comunicação Social. Uma oportunidade para sensibilizar os futuros produtores de artefatos midiáticos (publicitários e jornalistas) com o compromisso dos profissionais da área em discutir ou problematizar questões contemporâneas relacionadas com a cultura da mídia, sintonizada com a cultura do consumo do nosso tempo. Nas palavras de Achutti (1997, p. 28), temos mais uma vez evidenciada a necessidade de aproximar o campo da Comunicação e da Educação para construir estratégias que oportunizem a discussão e produção de imagens:

se vivemos em um mundo visual, no qual somos bombardeados por ícones novos a cada dia, se as diferentes culturas impõem, umas às outras, verdadeiras guerras visuais, se as guerras verdadeiras passam a ter o visual de meras brincadeiras, como olhar somente para as palavras?

Neste sentido, a importância que as imagens midiáticas têm assumido em nosso cotidiano provocou certa inquietação em nossas práticas educativas, despertando o desejo de discutir o papel que as fotografias como artefatos culturais têm desempenhado na constituição de identidades culturais. $\mathrm{O}$ ato de fotografar nos dá a possibilidade de ver por outro ângulo, tira-nos da zona de conforto e nos faz querer ver o que outras pessoas não viram. A partir das discussões deste estudo, podemos afirmar que o uso da mídia e da fotografia no campo da Educação abriu novas possibilidades de ver a relação escola, mídia, consumo e produção de imagens. 


\section{Referências}

ACHUTTI, L. E. R.. Fotoetnografia, Um estudo de Antropologia Visual sobre cotidiano, lixo e trabalho. Porto Alegre: Livraria Palmarinca/Tomo Editorial, 1997 .

BRUM, A. SCHMIDT, S.. Fotografando a Matemática no Bairro: Um Estudo Sobre Comunicação e Educação. XXXVIII Congresso Brasileiro de Ciências da Comunicação. Anais... Foz do Iguaçu, 2014.

BRUM, E. A vida que ninguém vê. Porto Alegre: Arquipélago Editorial, 2006.

DREIFUSS, R. Tecnobergs globais, mundialização e planetarização. In: MORAES, Denis de. Por uma outra comunicação. São Paulo: Ed. Record, 2003.

FISCHER, R. B. Identidade, Cultura e Mídia: a complexidade de novas questões educacionais na contemporaneidade. In: SILVA, Luis Heron (org.). Século XXI. Qual conhecimento? Qual currículo? Petrópolis: Vozes, 1999.

GARCIA, W. O corpo na fotografia: anotações. In: Fotografia Contemporânea. 2007.

GURAN, M. Linguagem fotográfica e informação. Rio de Janeiro: Rio Fundo, 1992.

HURTER, B. Fotografia de Retratos. -3. Ed. Balneário Camburiú, SC: Photos, 2011.

JOBIM, S. Fotografar e Narrar: A produção do conhecimento no contexto da escola. Faculdade de Educação da Universidade do Rio de Janeiro, 2002.

LEITE, M. L. M. Imagem e Educação. In: Seminário “Pedagogia da imagem, imagem na pedagogia” Niterói: Universidade Federal Fluminense, 1996.

SAMAIN, E. O fotográfico. Editora Hucitec e Editora Senac - São Paulo, 2005.

SCHMIDT, S. A educação em tempos de globalização. Rio de Janeiro: DP\&A, 2001.

Aprendendo a ler nas lentes do jornal. 23 ${ }^{a}$ Reunião Anual da Associação de Programas de Pós-Graduação em Educação. Caxambu. Minas Gerais, 24 a 28 de setembro de 2000 . 
Entretanto, a prática no Ensino Superior parecia-me desconectada e não alcançada pelo discurso de aproximação entre comunicação e educação. O estágio de pós-doutoramento serviu para aguçar minha reflexão sobre esse foco de pesquisa e chamar a atenção para a necessidade de aprofundamento dos estudos sobre a relação comunicação e educação na prática pedagógica dos cursos superiores.

\section{A questão da tecnologia}

A onipresença da tecnologia na sociedade contemporânea tem provocado inúmeras transformações nas relações sociais, produções simbólicas de sentido e na capacidade de ver o mundo, alterando os conceitos de tempo e espaço. Dentro desse cenário, o espaço formal de educação e aprendizagem ganha contornos mais abrangentes e espontâneos, levando a uma reflexão urgente sobre o papel da escola e do educador na formação de indivíduos capazes de atuar em uma sociedade em trânsito.

Vivemos hoje uma mudança radical de paradigmas e uma revisão de conceitos preestabelecidos, como educação, comunicação, formação, informação e conhecimento. Com uma proposta de relação dialógica e participativa, o novo campo da Educomunicação parece apresentar respostas para as inquietudes da sociedade contemporânea.

\footnotetext{
Entenda-se por Educomunicação um conceito mais abrangente para pensar os fenômenos de ensino-aprendizagem sob as circunstâncias que matizam a vida contemporânea em sua pluralidade de dispositivos técnicos, estímulos à visualidade, desafios suscitados pelos circuitos digitais, instigações provocadas pelas estratégias de produção, circulação e distribuição da informação e do conhecimento (CITELLI; OROFI$\mathrm{NO}, 2014$, p. 14).
}

Como premissas, a Educomunicação sustenta o diálogo, o espaço para o conhecimento crítico e criativo, para a cidadania e a solidariedade presentes em todos os processos de ensino-aprendizagem, seja em âmbito formal, informal ou não formal.

Como a aprendizagem hoje em dia instituiu o "entre" - o espaço de intersecção entre as fronteiras das diversas áreas do conhecimento, é aí que se consolida a pertinência da Educomunicação como uma proposta de convergência tecno-educativa, que acompanha a necessidade de sujeitos cada vez mais aptos a transitarem na universalidade do conhecimento. 
Uma vez que a escola deixa de ser o único espaço de ensino-aprendizagem, a sociedade contemporânea estabelece outros elementos de formação, transitando entre a rigidez dos módulos sequenciais de ensino tradicionais e as novas perspectivas de experimentação, descoberta e desvelamento, propostas pelas novas tecnologias, como videogames interativos e de terceira dimensão (OROZCO GÓMEZ, 2004).

A utilização de recursos audiovisuais em sala de aula vem ocorrendo de forma gradativa e espontânea, calcada muitas vezes mais em iniciativas pessoais de educadores e alunos do que propriamente das instituições de ensino. Como a prática pedagógica é uma atividade muitas vezes solitária, as relações em sala de aula têm por base as interações ou não entre educador/aluno. As transformações para de fato ocorrerem precisam romper as barreiras e ultrapassar as portas das salas de aula. Isso implica em um convencimento e envolvimento dos educadores, que precisam estar abertos a mudanças e novas aprendizagens.

É por isso, talvez, que em pleno século 21, numa sociedade extremamente midiatizada e mediada pela tecnologia, ainda pautamos o processo educativo no livro e na atividade escrita, num sistema de avaliação que reforça a repetição e a memorização. A linearidade da prática pedagógica ainda é chave para a obtenção de diplomas e certificados de mérito escolar (BRAGA, 2001).

Como uma das mais profundas transformações da sociedade contemporânea é justamente o modo como circula o saber, o modo de produção do conhecimento, chegamos a um ponto em que não é possível retroceder. Estamos diante da sociedade da aprendizagem.

Autores como Francisco Gutiérrez e Néstor García Canclini, por exemplo, propõem que a escola se volte mais para a sensibilidade e envolvase com o mercado, com o consumo e com o sistema de comunicação. Com o mote "educação para a vida", seria fundamental que a escola educasse para as incertezas próprias dessa era da sociedade. Refletir sobre o consumo e suas tramas e emaranhados seria um tema apropriado e necessário para este momento da sociedade contemporânea.

Um dos pioneiros na inter-relação comunicação/educação no cenário latino-americano, Paulo Freire focaliza os processos comunicacionais que se inserem no "agir pedagógico libertador". Ele afirma que o homem é um ser de relação e não só de contatos como o animal, não está apenas no mundo, mas com o mundo. Além da ideia de emancipação, surge a concepção do coletivo, do sentido de grupo, que deve prevalecer sobre o indivíduo, no compartilhamento e na busca da ação libertadora. "A educação só pode ter cunho emancipatório" (FREIRE, 2006, p. 58). 
Nessa mesma direção aponta o educador chileno Mario Kaplún, que define a inter-relação como "comunicação educativa", destacando sua natureza: ela existe para dar à educação métodos e procedimentos para formar a competência comunicativa do educando. Não se trata de educar usando o instrumento da comunicação, mas que ela se converta "no eixo vertebrador dos processos educativos": educar pela comunicação e não para a comunicação. "Os conceitos de educação e comunicação passam a ser vistos como sequências de um processo cada vez mais inter-relacionado: requisitam-se para esclarecerem-se" (CITELLI, 2000, p. 17).

Dentro de todo esse contexto, repensar o conceito de formação é fundamental. Não basta incluir a tecnologia na prática pedagógica como adendo ou atrativo do conhecimento. É preciso preparar os educadores para exercerem um papel de mediadores nesse novo cenário tecno-informativo.

Segundo Citelli (2009), formação é um ato de apreensão e completude do sujeito na relação dele com o mundo, é um processo de retroalimentação que tem uma tensão permanente entre a experiência e a prática. "A experiência alimenta a formação, a vivência forma e transforma” (CITELLI, 2009, s/p). É nesse sentido que o processo de formação deve estar aberto para trabalhar com outros elementos comunicativos, entendendo que a comunicação é parte intrínseca desse conhecimento.

Falamos, aqui, não apenas da perspectiva didática do uso das tecnologias, mas da perspectiva civilizatória de conviver com as tecnologias em todos os espaços da vida em família, na comunidade e na escola, reconstruindo seu uso social, no espaço de uma agenda formadora de sujeitos políticos. Estamos na verdade diante de uma questão política, no sentido grego dado ao conceito de "Polis", imaginando como os atenienses se apropriavam da filosofia para repensarem constantemente seus vínculos mútuos e suas propostas de ação. O que propomos é saber como as tecnologias devem ser assumidas pela ampla comunidade educativa (a escola e seu entorno, somada à família, à mídia e à própria cidade educadora) (SOARES, 2008, p. 53).

Não acredito na tecnologia que transforma de forma autônoma os indivíduos, alterando o aprendizado de forma progressiva, mas sim numa tecnologia que pode servir de plataforma e incentivo ao diálogo, à participação e a uma nova relação entre sujeitos. Em paralelo, esses sujeitos em relação devem promover um espaço comum para a reflexão crítica, onde todos saem fortalecidos ou afetados/transformados por essa expressão de alteridade.

Como sempre nos referimos a sujeitos críticos, é importante também analisar o adjetivo crítico: 
É um termo frequentemente relacionado à divisão entre "nós" e "eles" - ou seja, as pessoas qualificadas como críticas são muitas vezes, simplesmente, aquelas que concordam conosco, ao passo que as que discordam de nós são tidas como aquelas que não sabem criticar. Isto representa uma versão do que já foi chamado de "efeito de terceira pessoa" em discussões sobre a influência das mídias: sempre os outros são considerados como não tendo competência crítica. Existe também sempre o perigo de que a "capacidade crítica" se torne uma das rotinas padronizadas ou um dos jogos de linguagem das aulas de mídias - um jogo no qual os alunos simplesmente devolvem ao professor as formas de discurso crítico que receberam dele (BUCKINGHAM, 2012, p. 52).

A pergunta então é como promover uma reflexão crítica profunda e verdadeira sobre a produção e recepção dos alunos referente às novas tecnologias? É nesse sentido que o Jornalismo entra como prolongamento do espetáculo, trabalhando em favor da lógica do consumo. Como romper com essa estrutura tão bem montada e enraizada em nossa sociedade, que funde publicidade, consumo e informação? O redimensionamento do espaço público abrange até mesmo os direitos fundamentais de cidadania, educação, saúde, ciência, política, etc., valores que se misturam com a prática diária de mercado.

Canclini (1995) observa que o poder do mercado e do consumo atuam até mesmo na destruição das ferramentas de leitura de mundo.

Há poucos anos pensava-se o olhar político como uma alternativa de leitura do mundo (imaginava-se que, mudando as estruturas políticas, se estaria transformando as relações sociais, tornando-as mais justas). O mercado desacreditou esta atividade de uma maneira curiosa, não apenas lutando contra ela ou exibindo-se como mais eficaz para organizar a sociedade, mas também a devorando, subvertendo a política às regras do comércio e da publicidade, do espetáculo e da corrupção (CANCLINI, 1995, p. 20).

A meta de formar jornalistas fica ainda mais desafiadora, levando os sujeitos a construírem novos modos de atuação na mídia e, por consequência, no mundo.

Concordo com Bucci (2000) que a preocupação atual deve ser com o preparo crítico, a formação ética do profissional e a apropriação do senso de sujeito, cheio de ideias e opiniões. Uma geração que não ignore seu papel de formadora de opinião, mas também o seu uso estratégico na ampliação do poder do mercado. 
A escola, então, deve continuar simplesmente formando para o mercado? Na contramão da lógica atual, as faculdades e os cursos de Jornalismo poderiam oferecer subsídios para que os futuros profissionais pudessem sim ser inseridos no mercado de trabalho, mas ao mesmo tempo transformarem suas práticas?

Roseli Figaro afirma que os alunos são tanto apocalípticos quanto integrados, e isso simultaneamente.

Parece paradoxal, mas não é. Essa posição revela-se com uma força cuja consequência é a continuidade do status quo, a perda da perspectiva da mudança resultante de um conjunto de atitudes que devem ser tomadas e assumidas pelo profissional crítico. Ou seja, ela exime o sujeito de qualquer responsabilidade por aquilo que está fazendo e forma o futuro comunicador compromissado apenas com os interesses do mercado, sem qualquer noção de responsabilidade com a sociedade civil (CITELLI; COSTA, 2011, p. 92).

O produtor de notícia necessita de preparo, de formação, de questionamento. $\mathrm{O}$ jornalismo precisa voltar a ser uma atividade intelectual, mais do que reprodutor de conteúdo. "Para fazer a crítica, é necessário desvendar, desconstruir, mostrar como essas linguagens são construídas, dar a conhecer, tornar a informação conhecimento" (CITELLI; COSTA, p. 94).

Em uma pesquisa com 538 jornalistas que trabalham em São Paulo, Figaro aferiu profundas mudanças no perfil da profissão, identificando que a formação política e crítica dos profissionais tem sido prejudicada nas últimas décadas.

Uma questão que nos preocupou foi que uma minoria, em torno de $30 \%$, tem noção de que o trabalho do jornalista é fundamental para preservar o direito do cidadão à informação. A maior parte vê a informação como um produto, um negócio. Quando colhemos os depoimentos, alguns deles chamaram a atenção pelo despreparo ou desinteresse desses profissionais com relação aos grandes temas e ao discernimento do papel do jornalista (FIGARO, 2013, s/p).

A relação Comunicação/Educação pode ser um caminho no sentido de resgatar a crítica, desconsiderando posições maniqueístas, mas permitindo a compreensão do processo de inter-relação social e seus desdobramentos na sociedade contemporânea, ensinando as pessoas a ler o mundo de maneira cidadã.

A Educomunicação pode ser aplicada aos cursos de graduação de jornalismo, e do ensino superior de maneira geral, contribuindo para que a discussão sobre a realidade seja frequente e que a capacitação vá além da apropriação ou utilização das novas tecnologias. 


\section{Época de transformações}

A grande transformação da sociedade nas últimas décadas trouxe impactos profundos no processo ensino-aprendizagem e na forma como as informações circulam entre as pessoas. A velocidade e o volume de conteúdo que são disseminados pelas novas tecnologias e pelos meios de comunicação também contribuem sensivelmente para um novo tipo de relacionamento tanto entre as pessoas quanto entre homem-máquina.

Ao longo da história, os sistemas de comunicação, aliados à tecnologia, têm alterado a capacidade de abstração e o pensamento do ser humano. O filósofo tcheco-brasileiro Vilém Flusser, citado por Menezes (2010), explica que a "escalada da abstração" é marcada por quatro grandes tipos de comunicação: a comunicação tridimensional, com gestos, cheiros e sons; a bidimensional, que tem como suportes sinais e imagens; a unidimensional, que inaugura o mundo da escrita; e a nulodimensional, caracterizada pelo algoritmo, pelo digital. Essa trajetória considera os elementos espaço/tempo fundamentais para os processos comunicativos, marcados tanto pela relação presencial quanto as mediadas por dispositivos tecnológicos.

Outra análise sobre a evolução da comunicação é realizada por Defleur e Ball-Rokeach (1993, p. 22), que demonstram que "é o domínio dos sistemas de comunicação usados para armazenagem, troca e difusão que representa os pontos de mudança críticos da história humana”. Além de possibilitar novas aprendizagens, os sistemas de comunicação estão relacionados à complexidade dos pensamentos e da própria estrutura social e cultural da sociedade.

De uma forma ou de outra, a centralidade da comunicação, especialmente a midiática, em nossa sociedade está intimamente ligada ao domínio e ao avanço tecnológico. Como lembra Canclini (1995, p. 284), "os meios de comunicação não têm responsabilidade exclusiva sobre as transformações culturais geradas pelas últimas tecnologias e pelas mudanças na produção e circulação simbólica". Entretanto, o nosso dia a dia está necessariamente vinculado à presença e à atuação da comunicação midiática (SOUSA, 2006).

Nomeada de Sociedade da Informação, a sociedade contemporânea estabelece o conhecimento como a "matéria mais custosa" e em que "o desenvolvimento econômico, social e político estão ligados à inovação". Martín-Barbero (2003, p. 36) enfatiza que o fatalismo tecnológico legitima a onipresença do mercado na sociedade, assim como o novo lugar da cultura na sociedade, 
quando a mediação tecnológica da comunicação deixa de ser puramente instrumental para espessar-se, densificar-se e se converter em estrutural, pois a tecnologia remete hoje não a novas máquinas ou aparelhos, mas a novos modos de percepção e de linguagem, a novas sensibilidades e escritas. [...] O que a trama comunicativa da revolução tecnológica introduz em nossas sociedades é um novo modo de relação entre processos simbólicos - que constituem o cultural - e as formas de produção e distribuição dos bens e serviços.

Canclini completa afirmando que o "mercado reorganiza o mundo público" e "a mídia se torna a constituinte dominante do sentido público". Comunicação midiática e mercado em simbiose reestruturam a sociedade. Em paralelo, a cidade "cede o protagonismo do espaço público às tecnologias eletrônicas” (CANCLINI, 1995, p. 290). Emaranhadas nessa tríade mercado, mídia e tecnologia -, as pessoas assumem papéis de dramatização social dentro da cultura do audiovisual, em que o real é a imagem criada pela mídia/tecnologia.

É dessa forma que Sodré define a Sociedade da Informação:

Corresponde a um modelo industrial que favorece a hibridização dos suportes técnicos, acompanhada da reciclagem acelerada dos conteúdos, com novos efeitos sociais. Uma fórmula já antiga, como o noticiário jornalístico, quando transmitida em tempo real, torna-se estratégica nos termos globalistas do mercado financeiro: um pequeno boato pode repercutir como terremoto em regiões do planeta fisicamente distantes (SODRÉ, 2002a, p.19o).

Diante dessa transformação, Sodré (2002b) enxerga uma nova esfera existencial, o que ele chama de quarto bios, formado pela virtualidade e pela informação. O homem se vê diante da midiatização da sociedade, que, impulsionada pelo mercado, tem pressa e urgência para satisfazer seus desejos.

Se quisermos lidar com o desafio tecnológico que assola a nossa sociedade, Martín-Barbero (2014) afirma que devemos estar atentos às dinâmicas que movem as mudanças: a incidência dos meios tradicionais e o impacto das novas tecnologias.

Na mesma linha, só que de forma mais otimista, Jenkins (2008, p. 27) afirma que vivemos a cultura da convergência, "onde as velhas e novas mídias colidem" e os consumidores e produtores são incentivados a encontrarem novas formas de interação. Ele acredita que a convergência está mais relacionada à forma como consumimos os meios do que propriamente à mudança tecnológica. 
Del Bianco (2012) concorda com Jenkins em relação à convergência ser mais que uma mudança tecnológica. Para ela, é um processo cultural que envolve fluxo de conteúdo, múltiplos suportes e mercados midiáticos, mas principalmente consumidores mais participativos. Ela apresenta quatro características da convergência na contemporaneidade:

1. A centralidade da internet - ambiente de informação, comunicação e ação múltiplo e heterogêneo;

2. As redes digitais - novas possibilidades de configuração, conexão, interfaces que alteram a produção, distribuição e transmissão de conteúdo;

3. Um sistema de comunicação complexo e adaptável - capacidade das formas de mídia se adaptar às mudanças e inovações tecnológicas;

- A coexistência entre meios novos e tradicionais - interatividade ativa e compartilhamento de informação. A partir da cultura de convergência, a sociedade é levada a ser mais participativa e a construir conhecimento de forma colaborativa, coletiva. Essa abordagem representa uma mudança de paradigma porque altera o nosso relacionamento com a mídia e cria um novo capítulo para a escola. "As pessoas aprendem mais, participam mais ativamente e se envolvem mais profundamente com a cultura popular do que com os conteúdos dos livros didáticos" (JENKINS, 2008, p. 236).

Jenkins defende a ideia de que o conhecimento pode ser compartilhado nas redes sociais e que a partir daí haveria uma forma coletiva e democrática de aprendizagem, na qual uma pessoa mais experiente ajudaria outra que está iniciando na internet, por exemplo. "O poder da participação vem não de destruir a cultura comercial, mas de reescrevê-la, modificá-la, corrigi -la, expandi-la" (JENKINS, 2008, p. 326).

É justamente nessa possibilidade que Jenkins (2008) vê a importância de uma educação voltada para os meios ou "letramento midiático". É nessa lógica que a escola, impactada pela tríade que impulsiona os discursos e comportamentos sociais e a aprendizagem, por consequência, é forçada a uma análise mais abrangente.

Como reforçam Morin (1986) - "para saber ver é preciso saber pensar o que se vê" - e Wolton - "a comunicação é um dos principais locais de leitura das contradições da sociedade moderna" (apud BARROS; KÜNSCH, 
2007), as mudanças em nosso mundo social impactam nossa forma de compreender a realidade.

Quanto mais a comunicação mediatizada se aprimora, rompendo as escalas de tempo e espaço, mais a comunicação direta, física, com o outro padece de uma desvantagem constrangedora. É mais fácil dialogar de um lado ao outro do planeta e, com isso, esquecer as dificuldades, inevitáveis, do "face a face". As técnicas não resolveram os problemas da comunicação humana; elas simplesmente os transferiram de lugar, empurrando-os, enfim, para os botões dos teclados e os monitores. Apesar de todas essas técnicas, cada vez mais simples, acessíveis, lúdicas e interativas, o outro continua sempre presente, ainda difícil de ser acessado, ainda difícil de ser compreendido e de despertar interesse. É como se as dificuldades da comunicação humana tivessem sido simplesmente colocadas entre parênteses devido às maravilhas tecnológicas (BARROS; KÜNSCH, 2007).

Para Braga e Calazans (2001, p.30), o papel da comunicação também é relevante em função do "desenvolvimento de processos mediáticos e da geração de procedimentos públicos”, além de o próprio ângulo comunicacional ter aumentado sua presença em espaço e atividades da sociedade, decorrente da "forte intensidade, diversidade e rapidez com que a interacionalidade mediatizada 3 se inscreve em todas as atividades humanas e sociais". Para eles, essa crescente participação da comunicação justifica repensar a função da escola e sua metodologia. Huergo (2000, p. 15) enfatiza que "a escola se encontra em uma profunda crise de hegemonia”, atestando a presença massificadora dos meios e apresentando um novo elemento:

Vivemos hoje uma acelerada revolução das percepções, das práticas, das representações e dos imaginários; mas não são tanto os meios e as tecnologias os que desafiam a escolarização, senão a tecnicidade e a cultura mediática na trama da cultura social. [...] O cenário educativo está testemunhando a impotência da racionalização (HUERGO, 2000, p. 15)

3 Braga propõe o uso da expressão interacionalidade em substituição à palavra interatividade, por considerar que esta última se restrinja ao tipo conversacional. Interacionalidade mediatizada seria, então, todos os tipos de interação promovidos ou possibilitados pelos meios de comunicação. "Na interacionalidade mediatizada ampla, o que importa mais é a situação de grupos e pessoas interagindo sobre produtos mediáticos, percebidos como disponibilidades sociais" (BRAGA; CALAZANS, 2001, p. 29). 
Com o discurso da modernidade em xeque, Huergo (2000) visualiza a crise de identidade e de referência das instituições, as diversas formas de aprendizagem e as estruturas que evidenciam os processos de exclusão e expulsão social.

Soares (1999, p. 20 também aponta "uma grande preocupação com as mudanças pelas quais passa a sociedade contemporânea, seja em termos de algo que se perde como de algo que se conquista". As profundas alterações ocorridas na sociedade contemporânea, além de tornar obsoleta a Educação e muitas vezes perniciosa a Comunicação, "aproximam as duas áreas pelas necessidades convergentes que suscitam” (SOARES, 1999, p. 21).

Para Setton (2004), o problema não vem de hoje e necessita de uma profunda reflexão por parte dos educadores.

No início deste novo século, registra-se um novo surto da síndrome audiovisual que vem perpassando a educação brasileira desde a década de 2o. Agora o vídeo, o computador e a internet são o socorro que se procura para reduzir o mal endêmico do desinteresse que incomoda nas salas de aula. [...] Há muitos anos a escola e seus responsáveis perderam espaço no processo de formação intelectual e pessoal dos sujeitos da atualidade. Há quase meio século ouvimos sobre a crise da educação (Arendt, 1997), o esvaziamento da escola (Dubet, 1996) e/ou o desprestígio dos professores (Nóvoa, 1991) (SETTON, 2004, p. 34 e 68).

Ela considera que uma das maneiras de vencer esse dilema é pensar numa "aproximação com o discurso e as questões que envolvem o jovem, ou seja, uma aproximação com a linguagem do cotidiano de uma geração que precocemente socializou-se com a cultura midiática" (SETTON, 2004, p. 68).

\section{Vamos pensar sobre o Ensino Superior?}

A partir da perspectiva de Paulo Freire (2006), de que a educação deve humanizar o homem para que ele possa transformar o mundo, as relações em sala de aula, também no Ensino Superior, necessitam de uma revisão, em vista das profundas inovações que alteraram comportamentos, percepções e relacionamentos na sociedade.

Há uma necessidade de uma análise mais profunda sobre a utilização das novas tecnologias e principalmente as formas que elas podem ser trabalhadas para ampliar o índice de aprendizagem e reflexão exigido pelos cursos de graduação. 
Um olhar crítico se faz absolutamente necessário:

A compreensão crítica da tecnologia, da qual a educação de que precisamos deve estar infundida, é a que vê nela uma intervenção crescentemente sofisticada no mundo a ser necessariamente submetida ao crivo político e ético. Quanto maior vem sendo a importância da tecnologia hoje, tanto mais se afirma a necessidade e rigorosa vigilância ética sobre ela (FREIRE, 2006, p. 102).

Concordo com Buckingham (2012) que não podemos ignorar a diversidade e a desigualdade nas experiências com a tecnologia pelos jovens. Portanto, somos críticos em relação à noção da "geração digital" ou "nativos digitais". A tecnologia sozinha não está transformando o processo de aprendizagem, nem alterando as relações de poder e muito menos gerando mais participação. As pessoas necessitam de estímulo para aprenderem a participar e a extrair das novas tecnologias todo o potencial de participação e compartilhamento coletivo.

Por isso, é papel do Ensino Superior ampliar a capacidade de reflexão dos alunos, construindo argumentos e pensamento criticamente, inclusive sobre as suas maneiras de participarem ou compartilharem informações nas redes sociais.

$\mathrm{O}$ advento da tecnologia digital indica uma necessidade de se estender a missão tradicional da escola [...] a escola existe, em parte, para proporcionar aos jovens experiências sociais, intelectuais e culturais que eles não teriam sem ela. [...] As escolas deveriam desempenhar um papel fundamental na tentativa de nivelar as desigualdades de participação, ou seja, o acesso desigual às oportunidades, experiências, habilidades e conhecimentos que irão preparar a juventude para uma ampla participação no mundo de amanhã (BUCKINGHAM, 2012, p. 56).

Se ainda não entendem, os professores do Ensino Superior precisam entender seu papel de mediadores, estabelecendo conexões entre teoria e prática, o diálogo entre culturas e gerações, e as habilidades entre domínios tecnológicos e saberes científicos. Como lembra Soares (2000, p. 14) "a questão-chave não está nas tecnologias, mas no próprio modelo de comunicação adotado".

Em busca de uma abordagem menos tecnicista, a Educomunicação pode oferecer subsídios para pensar os fenômenos de ensino-aprendizagem numa sociedade profundamente impactada pelos dispositivos tecnológicos. "Não adianta a tecnologia reforçar o processo educativo tradicional. É 
preciso antes de mais nada repensar a escola. Repensar a educação a partir dos próprios educandos [...] e verificar para que pode servir a tecnologia (OROZCO-GÓMEZ apud CITELLI, 2000, p. 23).

Não pretendo fechar conceitos ou estabelecer caminhos que devam ser padronizados porque uma das riquezas da relação professor-aluno está justamente no dinamismo e na possibilidade de adaptação dos conteúdos às necessidades de cada turma, cada disciplina. Por outro lado, é interessante aprofundar a reflexão sobre os resultados obtidos com a prática educomunicativa nos Ensinos Médio, Fundamental e Superior. Entretanto, a busca constante pela melhor maneira de construção coletiva de conhecimentos é uma forma de rever as relações em sala de aula e compreender a influência da tecnologia na sociedade da aprendizagem, o que pode trazer uma nova roupagem para o ensino em todas as suas etapas e processos. 


\section{Referências}

BARROS, L.; KÜNSCH, D. "Saber pensar seu pensamento”: reflexões em conjunto sobre epistemologia da comunicação. In: Líbero, Ano X, nº 20, dez. 2007, p. 9-20.

BRAGA, J.; CALAZANS, R. Comunicação \& Educação, questões delicadas na interface. São Paulo: Hacker Editores, 2001.

BUCCI, E. Sobre Ética e Imprensa. São Paulo: Companhia das Letras, 2000, p. 188-201.

BUCKINGHAM, D. Precisamos realmente de educação para os meios? In: Comunicação \& Educação. Ano XVII, n.2, julho/dez. 2012 p. 41-6o.

CANCLINI, N. Consumidores e cidadãos: conflitos multiculturais da globalização. Rio de Janeiro: Ed. UERJ, 1995.

Culturas Híbridas. São Paulo: Edusp, 1998.

CITELLI, A. Outras linguagens na escola. São Paulo: Cortez, 2000.

. Comunicação e Educação. A linguagem em movimento. São Paulo:

Senac, 2004.

Prova de erudição do concurso para professor titular do Departamento

de Comunicações e Artes. 05 nov. 2009. Escola de Comunicação e Artes da Universidade de São Paulo.

CITELLI, A; COSTA, C. (coord.). Educomunicação: construindo uma nova área de conhecimento. São Paulo: Paulinas, 2011.

CITELLI, A.; OROFINO, M. I. Uma apresentação entre mediações. In: OROZCO GÓMEZ, G. Educomunicação: recepção midiática, aprendizagens e cidadania. São Paulo: Paulinas, 2014.

DEFLEUR, M.; BALL-ROKEACH, S. Teorias da Comunicação de Massa. Rio de Janeiro: Jorge Zahar Ed., 1993.

DEL BIANCO, N. (org.). O rádio brasileiro na era da convergência. Coleção GP’s E-books. Volume 5. São Paulo: Grupo de Pesquisa Rádio e Mídia Sonora, Intercom, 2012. 
FIGARO, R. 12 jul 2013. São Paulo. Entrevista concedida ao IHU-Online. Disponível em <http://www.ihu.unisinos.br/entrevistas/521826-a-debil-formacao-politicados-jornalistas-entrevista-especial-com-a-professora-roseli-figaro>.

FREIRE, P. Extensão ou Comunicação? São Paulo: Paz e Terra, 2006.

HUERGO, J. “Comunicación/Educación: itinerarios transversales”. In: VALDERRAMA, Carlos Eduardo. Comunicación-educación: coordenadas, abordajes y travesías. Bogotá: Universidad Central, 2000, p. 3-25.

Una guía de comunicación/educación, por las diagonales de la cultura y la política. In: APARICI, R. (coord.). Educomunicacíon: más allá del 2.o. Barcelona: ed. Gedisa, 2010.

JENKINS, H. Cultura da Convergência. São Paulo: Aleph, 2008.

MARTÍN-BARBERO, J. Ofício de Cartógrado: travessias latino-americanas da comunicação na cultura. São Paulo: Edições Loyola, 2003.

Comunicação na Educação. São Paulo: Contexto, 2014.

MENEZES, J. Comunicação, espaço e tempo: Vilém Flusser e os processos de vinculação. In: COELHO, C. N. P.; LIMA JUNIOR, W. T. (orgs.). Comunicação: diálogos, processos e teorias. São Paulo: Pleiade, 2010.

OROZCO GÓMEZ, G. Comunicação, educação e novas tecnologias: Tríade do século XXI. In: Comunicação \& Educação. Ano VIII, n. 23, jan./abr 2002, p. 57-70.

De la enseñanza al aprendizaje: desordenamientos educativo-comunicativos en los tiempos, escenarios y procesos de conocimiento. Colombia: Nómadas, $n^{\circ} 21,2004$.

Educomunicação: recepção midiática, aprendizagens e cidadania. São Paulo: Paulinas, 2014.

SETTON, M. A cultura da mídia na escola. São Paulo: Annablume, 2004.

SOARES, I. "Comunicação/Educação: a emergência de um novo campo e o perfil de seus profissionais”. In: Contato, Brasília: Ano 1, n.2, jan./mar. 1999, pp. 19-74.

Educomunicação: um campo de mediações. In: Comunicação \& Educação. Ano VII, n. 19, set./dez. 2000, p.12-24. 
SOARES, I. Muitos Meios, Muitas Comunicações. In: Salto para o futuro, SEED/MEC, ano XVIII, Boletim 18, set/out/2008, 49-58.

Educomunicação: o conceito, o profissional, a aplicação. São Paulo: Paulinas, 2011.

Educomunicação: As múltiplas tradições de um campo emergente de intervenção social, na Europa, Estados Unidos e América Latina. (no prelo)

SODRÉ, M. Existe consciência ética na Imprensa? In: PAIVA, R. (org.). Ética, Cidadania e Imprensa. Rio de Janeiro: Mauad, 2002a, pp.187-196.

Antropológica do espelho: uma teoria da comunicação linear e em rede.

Petrópolis: Vozes, 2002b.

SOUSA, M. Recepção Midiática e Espaço Público: novos olhares. São Paulo: Paulinas, 2006. 


\section{A aprendizagem baseada em problemas no ensino de jornalismo ${ }^{1}$}

Ângela Ravazzolo
Janine Marques Passini Lucht
ESPM-Sul, Porto Alegre, RS

\section{Introdução}

O jornalismo como prática profissional e campo teórico de estudo tem enfrentado, nos últimos anos, mudanças significativas relacionadas, principalmente, à disseminação e ao largo crescimento da internet e das novas tecnologias como ferramentas de produção e divulgação de informações, notícias, histórias, entrevistas... São mudanças que inquietam estudantes, profissionais experientes e acadêmicos que se dedicam a refletir sobre a área. E essa inquietação precisa estar presente também nas trocas das salas de aula das faculdades de Jornalismo, como forma de garantir não apenas o conhecimento já consolidado e por tanto tempo repetido, mas especialmente a construção crítica de um novo conhecimento, aliando teoria e prática.

Com este artigo, pretende-se investigar como a metodologia da aprendizagem baseada em problemas (do inglês Problem Based Learning PBL) pode ser uma ferramenta para provocar essa reflexão crítica entre os estudantes. Para a discussão que se propõe aqui, foram utilizados autores e teorias consolidadas que exploram uma conceituação mais geral do jornalismo, especialmente em relação ao elemento contraditório que costuma pontuar a escrita e a edição das notícias. E também teóricos da área da educação, que

1 Trabalho originalmente apresentado no GP Comunicação e Educação do XV Encontro dos Grupos de Pesquisa em Comunicação, evento componente do XXXVIII Congresso Brasileiro de Ciências da Comunicação. Texto com revisão e atualização para esta publicação.

2 Professora doutora do curso de jornalismo da ESPM-Sul. E-mail: aravazzolo@espm.br.

3 Professora doutora do curso de jornalismo da ESPM-Sul. E-mail: janine@espm.br. 
tratam de metodologias ativas, especialmente a PBL. O objetivo é relacionar prática e teoria a partir de um exemplo prático de um problema que pode ser utilizado em sala de aula e que deve seguir um método de aplicação específico, de acordo com a metodologia PBL.

O texto está dividido em quatro seções. Na primeira, estão colocadas algumas questões teórico-práticas, a partir de autores como Mota (2002), Martino (2014) e Figaro (2013). Nas duas seguintes, são elencadas as características das metodologias ativas de aprendizagem com ênfase em PBL. Uma quarta seção apresenta um exemplo de problema, formulado pelas autoras, e possibilidades práticas para utilizá-lo em sala de aula, como forma de estimular a autonomia e a crítica do estudante diante dos desafios contemporâneos da profissão.

Embora a descrição de PBL e de sua aplicação esteja diretamente relacionada à prática didática em sala de aula, é fundamental iniciar esse debate pontuando algumas questões teóricas do campo do jornalismo, seguindo, assim, a mesma lógica que se pretende colocar aos alunos, de convergência entre prática e teoria e a consequente reflexão sobre ambas.

\section{O contraditório na essência do jornalismo}

Como nasce uma notícia? Os caminhos para que um fato, uma pessoa ou uma situação se transformem em notícia jornalística costumam ser sinuosos e não necessariamente óbvios. Entre tantos acontecimentos e personagens, parte deles é selecionada e publicada, transformando-se em matéria -prima do jornalismo. Ao longo do tempo e dependendo do lugar, os critérios de escolha alteram-se, compondo diferentes panoramas. Atualmente, essas características precisam ser entendidas à luz das transformações ligadas ao crescimento da internet, das redes sociais.

Para alguns autores, estamos começando a deixar para trás um cenário "industrial” de produção e distribuição de conteúdo jornalístico, organizado a partir de grandes corporações de mídia, para dar lugar a um contexto "pós-industrial", em que as novas tecnologias permitem uma maior liberdade e acesso para circulação e publicação de informações (ANDERSON; BELL; SHIRKY, 2013).

Os desafios contemporâneos e os recentes campos de atuação que se apresentam ao jornalismo apontam para novas possibilidades de prática profissional e, consequentemente, reforçam a necessidade de práticas pedagógicas 
que estejam conectadas a esse contexto. Uma condição que exige ainda a retomada de uma discussão que aborde pontos fundamentais do debate teórico. O ensino em sala de aula não pode estar descolado desse debate teóricometodológico.

Um conceito mais amplo de jornalismo e os critérios de noticiabilidade incluem diversos pontos e variam, muitas vezes, de um autor a outro. Para este artigo, foram selecionados textos de Luiz Gonzaga Mota (2002) e Luís Mauro Sá Martino (2014) - não com o objetivo de esgotar o assunto, porque interessa aqui explorar a noção de conflito, do elemento contraditório que costuma pontuar a escolha, a redação e a edição de conteúdo jornalístico, em diferentes meios. Elemento diretamente relacionado à metodologia de aprendizado que se pretende explorar mais adiante no texto.

Mota (2014, p. 26) explicita critérios para que a notícia se constitua como tal, salientando o papel do conflito que rompe com o fluxo inicialmente esperado ou previsto:

Antes de prosseguir, é preciso destacar, ainda que rapidamente aqui, que o conflito é tomado como o valor-notícia predominante. Parte-se da ideia de que notícia é fundamentalmente conflito, ruptura, interrupção do fluxo esperado de significações. O que torna uma certa ocorrência anormal, o que a torna algo extraordinário e a credencia a ganhar o estatuto de notícia, é a sua percepção como um sentido que surpreende, que salta fora dos fluxos esperados de significações dos nossos cotidianos rotineiros. Para ser notícia, algo tem que ser percebido como um sentido extraordinário, como uma significação diferente dos nossos fluxos hegemônicos de sentido do mundo cotidiano da vida. Tomadas a partir do conflito, as notícias oferecem igualmente a matéria prima para a análise da narrativa, cuja essência está igualmente no conflito.

Martino (2014 p. 39) também relaciona a narração da notícia à ideia de uma contradição que permeia o texto jornalístico:

Escrever uma notícia significa, na maior parte do tempo, um esforço para coordenar informações de várias fontes, às vezes contraditórias, em uma escrita compreensível para o leitor. Isto é, reduzir a complexidade dos vários eventos em um texto simples e legível, com limites claros de tamanho, tempo de criação e dificuldade.

A contradição e o conflito pontuam as escolhas e as escritas jornalísticas em boa parte dos casos, mas há ainda um outro ponto que interessa levantar aqui: o desafio de produzir uma narrativa em um tempo limitado, determinado pelo horário de fechamento do jornal diário ou pela urgência 
do rádio e da televisão no século passado. Velocidade ainda mais voraz agora no século XXI, com a disseminação da web. E essa tirania tão conhecida dos jornalistas, que em parte determina a forma como uma notícia será apurada e apresentada ao público e pode ser entendida a partir da teoria do Newsmaking. Os estudos dentro dessa perspectiva teórica se propõem a identificar as estratégias utilizadas pelos veículos de comunicação e pelos próprios jornalistas na confecção do produto jornalístico, na tentativa de elucidar por que determinadas tomadas de decisão ocorrem no cotidiano da prática profissional. Muitas vezes, de acordo com Martino (2014, p. 39), essas escolhas passam despercebidas pelos jornalistas, mas "desconstruir o discurso jornalístico pode ser entendido como um esforço para identificar as várias vozes dentro da notícia”. Um esforço que - se não costuma ser feito dentro das redações, como deveria - precisa ser estimulado em sala de aula, escapando, assim, da armadilha de não reconhecer as contradições intrínsecas à prática jornalística.

Vale a pena notar que profissionais da comunicação não estão sempre conscientes desse procedimento. Vários estudos mostram uma tendência dos profissionais em diminuir a importância dessas escolhas, como se fossem absolutamente óbvias e inevitáveis. Negar esses aspectos arbitrários da escolha ironicamente reforça o argumento de que as estruturas de conhecimento usadas por uma pessoa são invisíveis para ela mesma, aparecendo como natural (MARTINO, 2014, p. 38).

Quanto mais consciente estiver o estudante de sua prática como jornalista, com consciência teórica que marque essa reflexão, mais chances ele terá de escapar dessa armadilha da "invisibilidade”, ou poderíamos identificar como uma "falta de autocrítica".

A partir de um outro ponto de vista, igualmente interessante para pensar essa condição contemporânea da profissão, Roseli Figaro (2013) investiga e analisa as mudanças no mundo do trabalho de jornalistas, em entrevistas com os próprios profissionais. No estudo em questão, são apresentadas algumas conclusões interessantes sobre as condições de trabalho e ainda sobre inquietações relatadas pelos entrevistados. Entre elas, o tempo exíguo para executar determinadas tarefas, e ainda a exigência de atender a públicos e negócios diferentes do modelo tradicional, em plataformas e linguagens ainda não consolidadas (FIGARO, 2013).

Com as dificuldades da aceleração dos tempos, da variedade de plataformas e da convergência de mídias aparecem problemas que não são exatamente novos, eles se recrudescem sem solução. Dizem respeito às orientações deontológicas da profissão, da ética jornalística 
ao tratamento com as fontes, à visão voltada para o interesse público, e não ao público cliente. Essas dificuldades são enunciadas na contraposição: manter os fundamentos ou atender à loucura dos ritmos e demandas do trabalho (FIGARO, 2013, p. 135).

As condições do lugar e do ritmo de trabalho e a ideia do elemento contraditório são pontos que fortalecem a proposta de trabalhar com metodologias ativas de aprendizagem com estudantes de jornalismo, buscando despertar nos alunos a reflexão teórica sobre como e por que se produz um determinado tipo e estilo de jornalismo e, ao mesmo tempo, provocando um debate em torno de estratégias práticas para execução, no dia a dia profissional, que eles vão encontrar no mercado depois de formados. Para tanto, é importante compreender as características básicas que marcam as metodologias ativas, especialmente a aprendizagem baseada em problemas ou PBL.

\section{Metodologia ativa em um cenário de mutação}

O jornalismo vem experimentando significativas mudanças no cenário atual. $\mathrm{O}$ avanço das tecnologias e o declínio das mídias tradicionais trazem certo grau de incerteza para o mercado da comunicação. Embora surjam novos negócios na área de mídia (startups) a cada dia, ainda não há como prever um cenário certeiro para o futuro, mesmo que próximo. Neste contexto, o ensino de jornalismo também enfrenta desafios. Várias são as causas para essas alterações. Machado (2011, p. 7) aponta algumas, a saber:

reestruturações econômicas, políticas, sociais, culturais e educacionais vividas pelas sociedades contemporâneas; a internacionalização dos processos educacionais com os intercâmbios acadêmicos, a complexificação das práticas profissionais como consequência da incorporação das tecnologias digitais em escala mundial e, por fim, a progressiva institucionalização em nível universitário da formação dos profissionais em relação ao seu modo de produção e a academia precisa estar preparada para receber os estudantes nativos digitais.

O método tradicional - que reconhece a competência docente - derivado do modelo jesuítico preconizava os três passos básicos de uma aula: preleção do conteúdo pelo professor, levantamento de dúvidas dos alunos e exercícios para fixação, cabendo ao aluno a memorização para a prova (ANASTASIOU; ALVES, 2004). Esse modelo, no entanto, não atende mais à realidade educacional contemporânea, muito mais focada nas capacidades humanas 
de pensar, agir e sentir de modo cada vez mais amplo e profundo, conforme Berbel (2011). O cenário que se desenha é o despertar da curiosidade dos alunos, tornando-os mais autônomos em suas relações escolares. Isso porque, com o surgimento das ferramentas digitais e de novas mídias, o profissional precisa desenvolver novas habilidades, tornando-se mais dinâmico para acompanhar o ritmo frenético de produção de informações (ANTONIOLI et al., 2014).

A desconexão entre a forma como os estudantes aprendem e a forma como os professores ensinam é fácil de compreender quando consideramos que o sistema educacional atual foi projetado para um mundo agrário e de manufatura. Entretanto, o mundo mudou e continua a mudar rapidamente. Os alunos multitarefa de hoje estão melhor equipados para esta mudança do que muitos adultos (JUKES; DOSAJ, 2003 apud VERAS, 2011, p. 1).

Mas o jornalismo multitarefa, ou multiplataforma, não é o "culpado" por demandar um estudante mais atento e conectado. Há muito já se percebe o desinteresse crescente dos alunos em sala de aula. Paulo Freire (1996 apud BERDEL, 2011, p. 29) já defendia que "na educação de adultos, o que impulsiona a aprendizagem é a superação de desafios, a resolução de problemas e a construção do conhecimento novo a partir de conhecimentos e experiências prévias do aluno". O objetivo das metodologias ativas, portanto, é alcançar e motivar o discente, para que este possa examinar, refletir e relacionar a história ao problema proposto, ressignificando suas descobertas (BASTOS, 2006 apud BERBEL, 2011).

A seguir, será explorada a metodologia de aprendizagem baseada em problemas (PBL) como um caminho possível para instigar e incentivar os estudantes para que exerçam a autonomia sobre a sua própria aquisição de conhecimento, de acordo com um cenário que enfrenta rápida mutação, tanto em relação ao mercado de trabalho quanto aos próprios desafios da educação contemporânea.

\section{$\mathrm{PBL}^{4}, \mathrm{o}$ aprendizado baseado em problemas}

Dentro do universo das metodologias ativas, o PBL, do inglês Problem Based Learning, insere-se na abordagem humanista, aquela na qual "o

4 No Brasil, a PBL é também conhecida como ABP, ou aprendizagem baseada em problemas. 
professor não transmite o conteúdo, mas dá assistência aos estudantes, atuando como facilitador da aprendizagem" (GIL, 2011, p. 11). Isso porque "o método consiste em desenvolver competências através da resolução de problemas estruturados, cuja solução dependa ( sic) da utilização de conceitos ainda não conhecidos ou estudados pelos alunos" (VERAS, 2011, p. 91).

O modelo ganhou destaque e relevância na Universidade de McMaster (Canadá), no final dos anos 1960 e, mais tarde, passou a ser adotado em outras instituições como a Universidade de Maastricht (Holanda) e a Escola de Medicina de Harvard (EUA) (SANTOS, 2010). Durante muito tempo, a abordagem esteve restrita aos cursos das áreas médicas. Aos poucos, a eficácia do modelo de ensino-aprendizagem, que valoriza as competências dos estudantes, técnicas e transversais, passou a ser valorizada, inclusive, por parte do mercado (instituições empregadoras). Santos et al. (2010, p. 2) salientam as virtudes do modelo, que propicia melhorar "as capacidades de comunicação, o pensamento crítico, a integração, negociação, trabalho em equipe, liderança, adaptação, autonomia, criatividade, entre outros".

A PBL também exige um raciocínio analítico, lógico, crítico, capacidade de síntese e autonomia. Requer um espírito empreendedor, flexível e comprometido por parte do estudante. Outra dimensão abarcada é a gerencial, pois demanda gestão do tempo e "treina" o processo da tomada de decisão (VERAS, 2011).

O aprendizado baseado em problemas deve ser sempre aplicado em grupos para permitir o compartilhamento de dúvidas e pesquisas na própria equipe. Além disso, é importante observar o intervalo entre a apresentação do problema aos estudantes e sua resolução, deixando tempo para as investigações fora da sala de aula.

A aplicação do método requer a observância de sete passos: primeiro, o professor apresenta o problema, que pode ser um texto, um trecho de filme, um áudio, por exemplo. Em seguida, procede ao esclarecimento dos termos difíceis para a turma, se houver; no terceiro estágio, o professor define os problemas a serem entendidos e explicados. A seguir, inicia a análise do problema. É o momento do brainstorm, para sanar as possíveis dúvidas, de acordo com os conhecimentos prévios. O passo seguinte é o resumo do tema, feito pela turma. Em seguida, os estudantes formulam os objetivos de aprendizagem (que já foram predeterminados pelo professor e que posteriormente serão confrontados com a turma), ou seja, devem extrair da situação exposta a definição do problema a resolver. O sexto passo deve ser realizado no espaço entre os encontros com o professor, fora do ambiente de sala de 
aula. No encontro seguinte, o grupo - ou time - relata aos demais colegas sobre os "achados" da pesquisa. Abre-se espaço para a discussão no grande grupo, em sala de aula.

Ao longo de todo o processo da sequência de sete passos, o professor tutor, que "aplica" a PBL, atua como mediador e não como mero fornecedor de informações ou tomador de decisões. O processo de avaliação também requer mudanças: é essencialmente formativo, baseado no processo integral, e deve contar com a participação de todos os envolvidos. Mas, para que esse sistema funcione, o apoio e o feedback do professor são fundamentais.

\section{A PBL em ação: a aplicação do problema}

Para o maior êxito de toda essa metodologia que se inicia a partir de um problema apresentado aos alunos, é necessário observar - ainda na fase de formulação do mesmo - alguns itens. De acordo com Borges et al. (2014), os problemas entregues aos estudantes devem reunir algumas características:

1. Fácil leitura e adequados ao nível de conhecimento do grupo;

2. Conter situações que os estudantes vão enfrentar na "vida real";

3. Estimular a integração do conteúdo básico e prático;

4. Conter pistas para ativar o conhecimento prévio e guiar os estudantes durante a discussão;

5. Não devem ser muito concisos nem muito amplos;

6. Não devem conter pistas escondidas, ser muito simples nem muito complexos.

Como estratégia para ilustrar a proposta deste artigo, foi elaborado um problema como exemplo para ser usado em sala de aula. A sugestão inicial é de que ele possa ser utilizado em disciplinas como "Introdução ao Jornalismo”, “Apuração, entrevista e reportagem”, “Jornalismo Impresso”, "Mídias Digitais", entre outras.

A partir do lançamento recente do livro Número Zero e de entrevistas concedidas pelo autor da obra, o escritor italiano Umberto Eco, o que se propõe com este problema é um debate que percorre diferentes caminhos, envolvendo as transformações contemporâneas por que passa o 
campo jornalístico, as relações entre política e jornalismo há muito existentes, além de limites e possibilidades profissionais que se multiplicam na velocidade de expansão da internet como ferramenta de divulgação de notícias e compartilhamento de informações.

Segue, abaixo, o exemplo criado para este trabalho e que deve ser entregue aos alunos em sala de aula como ponto de partida para a prática da PBL:

\section{Número Zero: desafios do jornalismo contemporâneo}

O italiano Umberto Eco lançou este ano um novo romance, que tem como temática central a prática jomalística. Nas páginas de "Número Zero", o escritor constrói uma crítica ao jornalismo e aos jornalistas. Embora seja um romance, o próprio autor já disse que os fatos relatados no livro "pertencem à categoria das conspirações reais" (entrevista à revista Veja em $1^{\circ}$ de julho de 2015).

No lançamento do livro, Eco concedeu diversas entrevistas e fez duras críticas ao mau uso da internet e à forma como os jornais impressos se comportam, alertando para a necessidade de uma crítica mais eficaz e rigorosa do que é veiculado na web. Para a revista Veja, ele chegou a dizer que "Com a internet e as redes sociais, o imbecil passa a opinar a respeito de temas que não entende".

Para o escritor, os jornais diários começaram a entrar em crise já na década de 50, quando a mídia impressa não soube se posicionar de forma diferenciada em relação à TV. E a sugestão de Eco para os tempos atuais é, no mínimo, provocativa: para ele, os jornais diários deveriam se transformar em "semanários", só assim teriam mais tempo de produzir suas reportagens de forma adequada.

Diante desse quadro e a partir das declarações do escritor, discuta em grupo os limites e as possibilidades dos jornais e dos jornalistas diante do manancial gigantesco de informações que circulam pela internet.

Fontes de consulta: em anexo, você encontra a integra da entrevista à revista Veja, e a entrevista publicada no site do El Pais Brasil está disponivel no link a seguir: http://brasil.elpais.com/brasil/2015/03/26/cultura/1427393303-512601.html.

Seguindo a metodologia PBL, o texto apresentado acima deve ser entregue aos alunos para que eles discutam em pequenos grupos, a partir das 
declarações do escritor, de acordo com os sete passos previstos na metodologia, conforme já citado. Organizados nessas equipes iniciais, a partir de um brainstorming, os estudantes deverão debater questões levantadas no texto recebido e, ainda, elaborar e apresentar possíveis objetivos de aprendizagem que aquele problema propõe. Embora o professor já tenha preparado previamente esses objetivos, é interessante que, neste primeiro momento, eles não sejam revelados aos estudantes, permitindo que a turma atue ativamente nesse processo de descoberta e aprendizagem, com autonomia e acessando seus próprios conhecimentos.

Em relação ao problema-exemplo baseado nas entrevistas de Umberto Eco, foram elencados os seguintes objetivos de aprendizagem:

a) Conhecer o cenário atual de crise que marca os jornais impressos diários;

b) Estabelecer relações entre esta crise de leitores e anunciantes e a expansão da internet;

c) Reconhecer os limites entre informações falsas e verdadeiras, entre aquelas que têm interesse público (jornalístico) e aquelas que não passam de curiosidades sem relevância social;

d) Elencar práticas jornalísticas que funcionem como estratégias para enfrentar esse cenário de crise.

Com esses quatro objetivos, pretende-se dar conta de uma série de questões e temáticas contemporâneas fundamentais para a formação dos jovens jornalistas. O primeiro prevê um entendimento do cenário contemporâneo de transformações, constituído especialmente a partir das novas tecnologias e da expansão da internet. $\mathrm{O}$ segundo objetivo refere-se à crise que deriva desse novo cenário, com alterações no modelo industrial jornalístico que se consolidou ao longo do século XX. Com o terceiro ponto, a intenção é retomar conceitos que marcam a história do jornalismo (interesse público e social versus amenidades e curiosidades “desimportantes") e que ficam ainda mais evidentes na internet, segundo as palavras do próprio Umberto Eco. Por fim, o quarto objetivo permite que os próprios alunos ensaiem e pensem sobre diferentes possibilidades para encarar com sucesso esses novos desafios.

A segunda etapa de trabalho com os estudantes, seguindo os sete passos previstos, permitirá que os próprios estudantes pesquisem - fora da sala de aula - , reúnam o material encontrado e apresentem o resultado das 
discussões em grupo e das pesquisas individuais em aula, em um encontro seguinte ao primeiro. Desta forma, sabe-se que os grupos chegarão a resultados distintos entre si, por vezes até mesmo contraditórios, fugindo daquele modelo tradicional que estabelece limites rígidos entre o certo e o errado. Pelo contrário, a utilização de um problema coloca o discente diante do desafio de entender ativamente um determinado cenário, buscar alternativas, encontrar novas perguntas, escapar de um modelo fixo e partir para uma ou várias respostas que sejam diversas e complexas, reunindo nessa busca aqueles conhecimentos já internalizados e os novos, que serão encontrados no processo de pesquisa individual e em grupo.

Esse processo de descoberta pode ser relacionado com a ideia de Paulo Freire (1996), de que não há validade no ensino se o aprendizado não resultar de um processo em que o aprendiz tenha sido capaz de "recriar ou refazer o ensinado". O educando, para Freire, deve ser "sujeito da construção e da reconstrução” do saber, em uma relação dialógica com o educador, pontuada pela capacidade de comunicação (o autor utiliza a palavra "comunicabilidade" para reforçar essa característica ou exigência no processo de aprendizado) (FREIRE, 1996).

Neste processo, é importante lembrar que o professor tem a função de ser um mediador, um tutor que auxilia nas dificuldades que se apresentam, incentivando sempre que as soluções sejam "pesquisadas" por seus pupilos, mas que não se exime do papel de apoio fundamental e de organização, de certa forma, dos trabalhos que serão apresentados em sala de aula após a pesquisa.

\section{Considerações finais}

O primeiro contato com a metodologia ativa $\mathrm{PBL}$ pode causar resistência, tanto por parte do corpo docente quanto dos estudantes. Isso porque há uma significativa quebra de paradigma. O professor pode se sentir privado do seu direito de expor todo o seu conhecimento, deixando de ser uma "fonte de informação privilegiada", e os discentes, porque saem da zona de conforto, tornando-se agentes do seu próprio processo de aprendizagem.

Embora o método possa sofrer críticas, ele é reconhecido por reforçar o papel ativo do aluno no processo de aprendizagem, permitindo que ele "aprenda a aprender". Voltando às ideias de Paulo Freire (1996), podemos ainda reforçar que esse tipo de postura desperta no estudante o que o 
educador chamou de "curiosidade epistemológica”, que escapa do senso comum, da ingenuidade, e se apresenta como um pensamento crítico e, possivelmente, inovador. Quando colocado diante de uma situação real, em que há um conflito latente e informações que provocam uma inquietação, como o problema exemplificado aqui, o estudante experimenta o "desconforto", um "desequilíbrio" e se vê, assim, desafiado a sair em busca de uma ou várias propostas para "solucionar” aquele problema.

Utilizar PBL em sala de aula permite unir a prática à teoria, na medida em que os próprios estudantes são desafiados a fazer essa ponte. A escolha pelas entrevistas de Umberto Eco para elucidar o que se pretendia com este artigo permitiu apresentar uma série de temáticas envolvendo o cenário contemporâneo do novo tipo de produzir jornalismo "pós-industrial” (não mais em escala industrial, que dependia necessariamente da distribuição das grandes corporações), e ainda questões sobre como se posicionar dentro de um imenso manancial de informações na internet, percebendo como a crise de anunciantes repercute nesse cenário e ainda as possibilidades de se posicionar como um empreendedor (quem sabe com a criação de uma startup?). São todos pontos que estão diretamente relacionados aos objetivos de aprendizado do problema e, mais do que isso, podem significar uma estratégia real de engajamento do estudante em sala de aula e ainda de desenvolvimento do pensamento crítico, capaz de perceber o contraditório conscientemente.

Ao mesmo tempo em que o estudante aprende a identificar a notícia, o que há de contraditório na sociedade e por isso mesmo precisa ser divulgado, explicado, denunciado, esse mesmo exercício de olhar crítico pode ser desenvolvido com PBL.

\section{Referências bibliográficas}

ANASTASIOU, L. G. C.; ALVES, L. P. (Org.). Processos de Ensinagem na Universidade. Pressupostos para as estratégias de trabalho em sala de aula. Joinville, SC: UNIVILLE, 2004.

ANDERSON, C. W.; BELL, E.; SHIRKY, C. Jornalismo Pós-Industrial. Adaptação aos novos tempos. Revista de Jornalismo ESPM, São Paulo, n. 5, p. 30-89, abr./maio/jun. 2013 . 
ANTONIOLI, M. E.; MANCINI, L.; PEREIRA, C. A. M.; LUCHT, J. M. P. Jornalismo em novos tempos: uma discussão sobre o ensino. In: ASSIS, F.; ANTONIOLI, M. E.; PEREIRA, C. A. M. (Org.). Desafios do jornalismo - Novas demandas e formação profissional. Curitiba: Appris, 2014.

BERBEL, N. A. N. A problematização e a aprendizagem baseada em problemas: diferentes termos ou diferentes caminhos? Interface, Botucatu, v. 2, n. 2, p. 139-154, 1998. Disponível em: < http:/www.scielo.br/pdf/icse/v2nz/o8>. Acesso em: 29 jul. 2015 .

BERBEL, N. A. N. As metodologias ativas e a promoção da autonomia de estudantes. Semina: Ciências Sociais e Humanas, Londrina, v. 32, n. 1, p. 25-40, jan./ jun. 2011.

BERTRAND, Y. Teorias contemporâneas da educação. Lisboa: Instituto Piaget, 2001.

BORGES, M. de C. et al. Aprendizado baseado em problemas. Medicina, Ribeirão Preto, v. 47, n. 3, p. 301-307, nov. 2014.

CRUZ, J. Umberto Eco: “A Internet pode tomar o lugar do mau jornalismo”. El Pais, São Paulo, 29 mar. 2015. Seção Cultura. Disponível em: <http://brasil.elpais. com/brasil/2015/o3/26/cultura/1427393303-512601.html>. Acesso em: 29 jul. 2015.

FIGARO, R. (Org.). As mudanças no mundo do trabalho do jornalista. São Paulo: Atlas, 2013 .

FREIRE, P. Pedagogia da Autonomia. Saberes Necessários à Prática Educativa. São Paulo: Paz e Terra, 1996. (Coleção Leitura).

GIL, A. C. Didática do Ensino Superior. São Paulo: Atlas, 2011.

LOWMAN, J. Dominando as técnicas de ensino. São Paulo: Atlas, 2012.

MACHADO, E. (Org.). O ensino de jornalismo na era da convergência. Conceitos, metodologias e estudos de casos no Brasil. Salvador: EDUFBA, 2011.

MARIN, M. J. S. et al. Aspectos das fortalezas e fragilidades no uso das metodologias ativas de aprendizagem. Revista Brasileira de Educação Médica, v. 34, n. 1, p. 13-20, 2010. Disponível em: <http://dx.doi.org/10.1590/So10055022010000100003 >. Acesso em: 29 jul. 2015. 
MARTINO, L. M. S. Teoria da Comunicação. Petrópolis: Vozes, 2014.

MITRE, S. M. et al. Metodologias ativas de ensino-aprendizagem na formação profissional em saúde: debates atuais. Ciência \& saúde coletiva, v. 13, supl. 2, p. 2133-2144, 2008. Disponível em: <http://dx.doi.org/10.1590/S141381232008000900018>. Acesso em: 29 jul. 2015.

MOTA, R.; SCOTT, D. Educando para inovação e aprendizagem independente. Rio de Janeiro: Elsevier, 2014.

MOTTA, L. G. Para uma antropologia da notícia. Revista Brasileira de Ciências da Comunicação, São Paulo, v. 25, n. 2 , p. 11-41, jul./dez. 2002.

OLIVEIRA, G. A. Uso de metodologias ativas em educação superior. In: CECY, C.; OLIVEIRA, G.A.; COSTA, E. Metodologias ativas: aplicações e vivências em educação farmacêutica. Brasília: Associação Brasileira de Ensino Farmacêutico e Bioquímico, 2010. p. 11-33.

SANTOS, A. et al. Problem-Based Learning e suas implicações: Breve revisão teórica. Porto: Instituto Politécnico do Porto, Escola Superior de Tecnologia da Saúde do Porto - Politema, 2010.

THOMSON, J. C. PBL - Uma proposta pedagógica. Olho Mágico, Londrina, v. 2, n. $3 / 4,1996$.

VERAS, M. (Org.). Inovação e métodos de ensino para nativos digitais. São Paulo: Atlas, 2011.

WOLF, E. A conspiração dos imbecis. Entrevista: Umberto Eco. Veja, São Paulo, $1^{\circ}$ jul. 2015, p. $15,18-19$. 


\title{
Texto, cena e a formação pela experiência ${ }^{1}$
}

\author{
Mei Hua Soares ${ }^{2}$
}

Cada manhã, recebemos notícias de todo o mundo. E, no entanto, somos pobres em histórias surpreendentes. A razão é que os fatos já nos chegam acompanhados de explicações. Em outras palavras: quase nada do que acontece está a serviço da narrativa, e quase tudo está a serviço da informação. Metade da arte narrativa está em evitar explicações.

Walter Benjamin

Durante a programação e o preparo de aulas de Língua Portuguesa para o curso de Comunicação (turmas de primeiro ano de Jornalismo), quase sempre se instaura o dilema sobre qual ensino enfatizar na formação superior: o voltado estritamente à aprendizagem técnica e utilitária (nesse caso, referente à língua) ou aquele que se volta à formação mais humanista e abrangente? A polarização já anuncia que o diálogo entre ambos seria o melhor caminho, mas, em geral, há muitas dúvidas quando as aulas se voltam à perspectiva formativa mais ampla.

No que diz respeito às disciplinas "adjacentes", ou seja, às disciplinas que não abordam conteúdos específicos da área escolhida, mas que a elas dão suporte (como acontece com as aulas de Língua Portuguesa), talvez seja possível lidar com essa perspectiva mais humanista e formativa. E, pensando nela, o teatro surge como mais uma possibilidade de ampliação de repertório, de estabelecimentos de relações e pontos de contato entre diferentes áreas.

1 Trabalho originalmente apresentado no GP Comunicação e Educação, no XXXVIII Congresso Brasileiro de Ciências da Comunicação. Texto atualizado para esta publicação.

2 Mestra e doutora em Linguagem e Educação pela Faculdade de Educação da Universidade de São Paulo. Docente do curso de Comunicação Social (Jornalismo) da Faculdade Cásper Líbero. 
Tateante em busca de didáticas e estratégias metodológicas que sustentem as práticas, o ensino que se volta à formação humanizada e sensível corre o risco de se tornar subjetivo ou "místico" demais. No entanto, questionando quais atividades se revelam mais significativas (conforme relatos e avaliações de discentes envolvidos), aquelas que se estruturam considerando as dimensões artísticas e coletivas são as mais citadas.

Mas em que consistiria, nesse contexto, o adjetivo "significativo"?

Pelo excesso de informação a que são submetidos os graduandos de Comunicação - em grande parte, jovens recém-saídos do ensino médio ou dos cursos de preparação para o vestibular - ou pela ausência de tempo para reflexão - tempo necessário para a maturação e para a divagação -, é perceptível que a torrente de conteúdos apresentados aos alunos se revela por vezes inócua. O tempo regulamentar das aulas pautado pelo limitado número de horas, a extensa programação curricular alternada com as exigências de estágio e de produção de trabalhos, entre outras demandas que acometem os alunos e alunas, são fatores que também contribuem para que o ensino-aprendizagem seja pautado por um ritmo frenético, mas, talvez, pouco substancial. Quando é possível romper minimamente com essa dinâmica veloz e incessante, por intermédio de ações ou atividades que a ela se contrapõem, existe a possibilidade de algo significativo ocorrer. Algo passível de ser lembrado, a que se permite a atribuição de sentido. Um conhecimento adquirido pela transmissão ou pela experiência conjunta.

Walter Benjamin (1994), ao localizar no romance moderno o indício que culminaria na "morte da narrativa", discorre sobre um saber proveniente da experiência, uma experiência passada de geração em geração, por intermédio de narrativas e histórias da tradição oral transferidas no boca a boca, em geral envolvendo trabalhos manuais ao longo da escuta. Esses momentos de troca serviam para fortalecer os vínculos entre os humanos próximos, mas também para preservar o que era importante a ser disseminado entre os mais velhos e os mais novos. Essas histórias sofriam modificações, mas mantinham seu caráter de perpetuar uma experiência coletiva válida entre seres humanos. Benjamin (1994) percebeu esse caráter importante da narrativa, e da experiência por ela desencadeada, justamente pelo seu reverso: o silêncio. Ao observar soldados que voltavam das guerras, notou que eles voltavam calados, incapazes de transformar em narrativa as atrocidades vivenciadas no 
front ${ }^{3}$. Esse mutismo, segundo essa concepção, seria o sintoma da extinção da narrativa e, por consequência, da experiência coletiva.

Salvaguardando as devidas diferenças, seria possível estabelecer breve paralelo entre o mutismo dos soldados de Benjamin e a suposta esterilidade de experiências - num contexto bombardeado pelo excesso de informações e demandas discursivas formais - no curso mencionado. Na busca pela ressignificação das aulas como possibilidade de travar experiências válidas individual e coletivamente, a retomada de elementos aparentemente rudimentares - como a roda de conversa, a leitura coletiva - mostrou-se especialmente válida.

Algumas experimentações metodológicas se revelaram potentes nesse sentido. Círculos de leitura (em voz alta, durante a aula) de diferentes gêneros literários; elaboração de crônicas e contos a muitas mãos; adaptação de contos de autores conhecidos e dos próprios alunos para a linguagem fílmica; apresentação de relatos identificados com temáticas tratadas em obras literárias lidas; leituras dramáticas. Foram muitas as tentativas de se romper com a frieza e rigidez das relações estritamente técnicas. Mas a que o presente artigo pretende abordar refere-se à linguagem e ao texto teatrais como dispositivo para alimentar a formação dos alunos de Comunicação.

Partindo de premissas obtidas ao longo de tese de doutoramento sobre práticas de leitura em grupos de teatro e do conteúdo programático curricular do curso de Comunicação, duas leituras dramáticas foram realizadas durante parte das aulas de Língua Portuguesa no ano de 2014: O beijo no asfalto, de Nelson Rodrigues, e O grande círculo da ideologia, da Cia. do Latão. O rei da vela, de Oswald de Andrade, foi encenada parcialmente pelos alunos organizados em pequenos grupos. A proposta envolvia o entrecruzamento de $\mathrm{O}$ rei da vela e fatos jornalísticos contemporâneos a partir da análise do viés político presente na peça. As experimentações foram especialmente interessantes pelo fato de os alunos saírem da zona de

3 No final da guerra, observou-se que os combatentes voltavam mudos do campo de batalha não mais ricos, e sim mais pobres em experiência comunicável. [...] Porque nunca houve experiências mais radicalmente desmoralizadas que a experiência estratégica pela guerra de trincheiras, a experiência econômica pela inflação, a experiência do corpo pela guerra material e a experiência ética pelos governantes. Uma geração que ainda fora à escola num bonde puxado por cavalos se encontrou ao ar livre numa paisagem em que nada permanecera inalterado, exceto as nuvens, e debaixo delas, num campo de forças de torrentes e explosões, o frágil e minúsculo corpo humano (BENJAMIN, 1994, p. 198). 
conforto, ou seja, assumindo riscos (por não serem atores, por não serem tão familiarizados com a linguagem teatral, por se exporem durante a realização da proposta), mas tendo como trunfo a possibilidade de errar (a máxima oswaldiana, a "contribuição milionária de todos os erros", foi um pressuposto de trabalho). Além das peças citadas, outra foi solicitada como leitura complementar - O furo no casco, de Chico de Assis - assistida, juntamente com a encenação de $\mathrm{O}$ grande círculo da ideologia, no teatro do Espaço Pyndorama, em espetáculo da Cia. Antropofágica, grupo teatral paulistano.

Por se tratar de uma “saída pedagógica” para um teatro não convencional (um lugar mais alternativo, subsidiado, essencialmente, pelo Programa de Fomento ao Teatro para a cidade de São Paulo, por intermédio de submissão de projeto em editais), por exigir o deslocamento dos alunos e alunas para um outro espaço que não o escolarizado, por esse espaço já consistir em lugar efetivo de trocas simbólicas entre artistas e público, a proposta revelou-se bastante significativa no sentido de proporcionar uma experiência válida coletivamente.

O objetivo deste artigo, no entanto, é pensar essas práticas pedagógicas que envolvem o texto dramático (ou dramatúrgico) e a linguagem teatral a partir do que foi pesquisado junto aos grupos teatrais. Recuperar os elementos e as descrições das práticas observadas durante os ensaios e leitura - sob a ótica da experiência fundamentada em reflexões de Jorge Larrosa Buendía (2002) - pode oferecer subsídios para se pensar as práticas formativas aplicadas em aulas de cursos de Comunicação.

\section{Teatro e experiência}

Entre 2010 e 2014, foram acompanhadas práticas de leitura e ensaios de duas companhias teatrais paulistanas (Cia. Antropofágica e Cia. Paidéia). Ambas mantêm, em seus procedimentos e processos, a perspectiva da formação enquanto elemento que engendra o fazer teatral. Esses dois grupos foram subsidiados pelo Programa Municipal de Fomento ao Teatro para a cidade de São Paulo em diferentes edições. De acordo com a pesquisa, que envolveu levantamento e estudo dos projetos ganhadores no Acervo de Fomento ao Teatro, foi constatado que o traço formativo, embora não decorra do próprio programa, é viabilizado por ele. Não são todos os grupos fomentados que se voltam para a formação, mas, de algum modo, mesmo quando a preocupação formativa não é explícita, clara, alguns fatores auxiliam na 
presença de um espectro formativo, de estudo, de pesquisa em quase todos os grupos teatrais que veem seus projetos selecionados. O próprio edital da Lei de Fomento enfatiza o caráter de pesquisa a partir de um projeto, de um tema que norteará as ações teatrais ao longo de seu desenvolvimento. Com seus projetos minimamente sustentados por um programa como esse, torna-se possível que um grupo mantenha - além do fazer teatral em si - uma perspectiva formativa contínua, o que implica muitas vezes em atividades a ela relacionadas (seminários, palestras, oficinas, diálogos, ciclos fílmicos, debates, etc.) que acabam reverberando entre o público.

Dentre essas ações formativas está a leitura. As leituras nas práticas coletivas teatrais em questão adquirem contornos específicos em virtude do contexto em que estão inseridas e do propósito a que servem, mas, conforme nossa hipótese, podem, em alguma medida, fornecer dados ou elementos para se pensar as leituras coletivas realizadas em aulas de Língua Portuguesa dos cursos de Comunicação.

Uma característica dessas práticas teatrais de leitura aponta para uma formação fundada a partir da experiência, que por sua vez geraria um saber dela proveniente. Utilizamos esse termo em referência a Walter Benjamin (1994), mas também às reflexões de Jorge Larrosa Bondía (2002) sobre esse tipo de formação. Flávio Desgranges (2006) também oferece contribuições para nosso estudo sobre a experiência teatral em sua dimensão educativa, ao lidar com o conceito de "estetização do olhar".

O espanhol Larrosa (2002) frisa, justamente, a formação que advém não mais do par ciência-técnica, ou do teoria-prática, mas do par experiência-sentido ${ }^{4}$, o que, na área de artes ou das humanidades, pode ser bastante revelador.

Não se trata de deixar de lado a técnica, o espírito científico, as teorias e práticas, mas ajustar o olhar na direção do que agrega sentido através

4 "Se o par ciência/técnica remete a uma perspectiva positiva e retificadora, o par teoria/ prática remete sobretudo a uma perspectiva política e crítica. (...) Se na primeira alternativa as pessoas que trabalham em educação são concebidas como sujeitos técnicos que aplicam com maior ou menor eficácia as diversas tecnologias pedagógicas produzidas pelos cientistas, pelos técnicos e pelos especialistas, na segunda alternativa estas mesmas pessoas aparecem como sujeitos críticos que, armados de distintas estratégias reflexivas, se comprometem, com maior ou menor êxito, com práticas educativas concebidas na maioria das vezes sob uma perspectiva política. (...) exploremos juntos outra possibilidade, digamos mais existencial (sem ser existencialista) e mais estética (sem ser esteticista), a saber, pensar a educação a partir do par experiência/sentido". (LARROSA, 2002, p.19). 
da experimentação, por intermédio da experiência vivenciada pelo indivíduo (ou pelo coletivo). Entretanto, se Larrosa (2002) afirma ser a experiência fundamental para a formação e a transformação do indivíduo, assinala, em contrapartida, a sua parca ocorrência. Para ele, a experiência só se torna possível mediante um contexto propício. Para tanto, tece quatro apontamentos a respeito da experiência que a elucidam enquanto fenômeno cada vez mais raro:

A primeira coisa que gostaria de dizer sobre a experiência é que é $\boldsymbol{n} \boldsymbol{e}$ cessário separá-la da informação. [...] Em segundo lugar, a experiência é cada vez mais rara por excesso de opinião. [...] a obsessão pela opinião também anula nossas possibilidades de experiência, também faz com que nada nos aconteça. [...] Em terceiro lugar, a experiência é cada vez mais rara por falta de tempo. [...] Em quarto lugar, a experiência é cada vez mais rara por excesso de trabalho (LARROSA, 2002, p. 22-23, grifos nossos).

Ao observar os quatro apontamentos e tentar relacioná-los ao nosso objeto de estudo, verifica-se nas práticas dos grupos teatrais analisados uma tendência ao atendimento dessas questões que circundam um determinado tipo de formação, o movido pela experiência/experimentação. Parece clara, tanto aos diretores como aos integrantes, a distinção entre a experiência teatral em si e a enorme quantidade de informações e dados que a circunscrevem. Se, por um lado, a leitura, o treino do corpo, da voz, o manejo de instrumentos e objetos são necessários, não são, no entanto, confundidos com o fenômeno teatral em si, nem com a experiência decorrente dele (ou dos elementos mobilizados por ele). O saber da experiência não é o texto, a peça, a música, mas o encontro desses elementos com o conjunto de recepção do indivíduo (referenciais, sensibilidade no momento, associações, atribuição de sentido, etc.). A experiência, ou a propensão a ela, parece estar mais latente no contexto teatral que no institucional. Isso talvez se deva ao fato de o teatro envolver o despertar dos sentidos para o sensível. Já nas aulas regulares (principalmente as do ensino superior), privilegia-se o conhecimento técnico-científico ou a teoria-prática, pouco ou nada contemplando os envolvidos com o par experiência-sentido.

O excesso de opinião parece ser uma tendência constantemente combatida nos grupos de teatro. Em função do seu caráter político, sua ênfase no estudo e na pesquisa aliada organicamente ao fazer teatral, os integrantes passam a debater e a questionar muitas coisas, o que é bastante saudável e, inclusive, desejável. No entanto, conforme a fala de uma das atrizes entrevistadas, muita leitura, muita reflexão política, pode gerar uma 
autocrítica que acaba por ocasionar entraves à criação. O excesso de informação ou de criticidade no momento da criação cênica pode atrapalhar a espontaneidade. Existe uma nítida preocupação com esse assunto quando um dos diretores comenta que os improvisos são essenciais, assim como o clima descontraído, as brincadeiras, o espaço para o descompromisso e o ócio. Segundo ele, nesses momentos é que podem surgir grandes criações, insights cênicos. Na graduação parece haver a polarização disso: ou há descontração demais, beirando a permissividade, ou só se obedece ao estudo burocratizado. Na passagem da escola básica, do ensino médio para o ensino superior, há o pressuposto da aquisição paulatina de conhecimento. No entanto, esse conhecimento, que é relativamente cíclico, acaba se afastando da experiência, pois atende a uma determinada ordem e permanência, conforme afirma Larrosa (2002, p. 23):

Desde pequenos até a universidade, ao largo de toda nossa travessia pelos aparatos educacionais, estamos submetidos a um dispositivo que funciona da seguinte maneira: primeiro é preciso informar-se e, depois, há de opinar, há que dar uma opinião obviamente própria, crítica e pessoal sobre o que quer que seja. [...] Com isso, nos convertemos em sujeitos competentes para responder como Deus manda as perguntas de professores que, cada vez mais, se assemelham a comprovações de informações e pesquisas de opinião. Diga-me o que você sabe, diga-me com que informação conta e exponha, em continuação, sua opinião: esse o dispositivo periodístico do saber e da aprendizagem, o dispositivo que torna impossível a experiência.

Raros são os momentos em que se permite a criação (ou ócio criativo), seja de que ordem for, pois isso implica no terceiro fator pontuado por Larrosa: o tempo. O tempo institucional, como já mencionado, é pautado por horários rígidos, é um tempo altamente controlado e controlador. Se compararmos com o tempo destinado aos processos teatrais, verificaremos que este último é expandido, ao passo que o primeiro é comprimido. No teatro de grupo (ao menos nos observados), há espaço para o erro, para o desvio, para as tentativas e fracassos, enfim, para experimentações. Ao acompanhar as madrugadas de ensaios (com duração de doze horas seguidas) e estudos dos grupos, ou dias inteiros dedicados ao fazer teatral (música, corpo, criação cênica, leituras, conversas, etc.), é possível vislumbrar um ambiente propício à experiência de que fala Larrosa (2002).

O quarto e último apontamento de Larrosa (2002) é um tema que apresenta desdobramentos mais sérios. Quando se debate a finalidade de formação superior, a orientação recai na preparação profissional e técnica, ou seja, 
uma formação especialista, voltada para a inserção no mercado de trabalho. Com essa exigência - institucional, familiar, social, econômica -, o jovem quase não encontra espaço (físico, psicológico, temporal) para uma formação que vise a outros elementos voltados para a aquisição de um saber de experiência, mais sensível, criativo, humano. Pensando nisso, ao tomar contato com jovens integrantes das companhias que, apesar do panorama desfavorável, insistem em fazer parte e permanecer em grupos teatrais que não oferecem "garantias profissionalizantes", remuneração (presente ou futura) ou mesmo perspectivas posteriores de inserção no mercado cultural (televisivo), torna-se inevitável a reflexão a respeito do que os move, do que os impulsiona a continuar. Para além da atividade que exercem - atuar, dirigir, apresentar -, existe uma postura de franca abertura entre os integrantes. A predisposição às trocas é bastante evidente durante o convívio e nos processos. Essa disponibilidade é semelhante ao que Larrosa (2002, p. 25) ressalta ao discorrer sobre o sujeito da experiência:

o sujeito da experiência se define não por sua atividade, mas por sua passividade, por sua receptividade, por sua disponibilidade, por sua abertura. Trata-se, porém, de uma passividade anterior à oposição entre ativo e passivo, de uma passividade feita de paixão, de padecimento, de paciência, de atenção, como uma receptividade primeira, como uma disponibilidade fundamental, como uma abertura essencial. O sujeito da experiência é um sujeito ex-posto. [...] Por isso é incapaz de experiência aquele que se põe, ou se opõe, ou se impõe, ou se propõe, mas não se "ex-põe". É incapaz de experiência aquele a quem nada lhe passa, a quem nada lhe acontece, a quem nada lhe sucede, a quem nada o toca, nada lhe chega, nada o afeta, a quem nada o ameaça, a quem nada ocorre.

O ambiente teatral favorável parece também se estender para a recepção constante de obras (teatrais, literárias, cinematográficas). Os integrantes dos grupos são submetidos a constantes recepções, seja de cenas dos colegas, seja de grupos convidados. Flávio Desgranges (2005), em estudo sobre a recepção e a experiência teatral, salienta a "estetização do olhar" do receptor (espectador, leitor) que se estabelece durante a recepção da obra, o que, segundo ele, engendra a dimensão pedagógica.

O exercício constante da contemplação - de peças, de leituras - provoca uma postura diferente, o que foi perceptível nos jovens integrantes dos grupos teatrais. Há um olhar, uma escuta treinada tanto para a recepção como para a criação. Essa constante movimentação e alternância de papéis sugerem desenvoltura, facilitação da criação e familiarização com os processos de recepção e de atuação. Nesse contexto, a leitura surge mais fluida, apropriada e orgânica, surge como potência passível de desencadear uma experiência válida. 
A palavra experiência vem do latim experiri (provar, experimentar). O radical periri também está presente em periculum (perigo), cujo sentido assemelha-se a "corte" ou "perda" (do inglês fading), sugeridos como metáfora da fruição literária por Roland Barthes em contraposição ao prazer (situado numa zona de conforto para o leitor). A experiência está, portanto, atrelada ao risco, à desestabilização, a algum "perigo". Além de envolver em seu cerne um perigo, o arriscar-se, encontra lugar no entre, na passagem de algum ponto a outro. Pressupõe ainda, em alguma medida, uma transformação, interna ou externa, significativa. A partir da definição de experiência de Heidegger (2003) - quando diz que "podemos ser assim transformados por tais experiências, de um dia para o outro ou no transcurso do tempo" - , Larrosa (2002, p. 25) salienta outro "componente fundamental da experiência: sua capacidade de formação ou de transformação".

Ao ator, à atriz, aos artistas de teatro, a inclinação à experiência aparece como condição. Suas práticas estão fundamentadas na transição de um personagem a outro, na alternância de tramas, de sensações e de vivências (fictícias e não fictícias). O convite à experiência, no teatro, é ponto pacífico. Se elas serão de fato experiências válidas, não se sabe. Mas o impulso está dado. A educação superior também pode (e por vezes o faz, geralmente em eventos isolados) impulsionar experiências significativas a alunos e professores. Existem experiências interessantes que geram desdobramentos valiosos. Talvez falte à educação especialista, dado seu caráter institucional e burocratizado, a paixão, descrita por Larrosa (2002, p. 26) como traço fundamental do sujeito da experiência.

Se a experiência é o que nos acontece, e se o sujeito da experiência é um território de passagem, então a experiência é uma paixão. Não se pode captar a experiência a partir de uma lógica da ação, a partir de uma reflexão do sujeito sobre si mesmo enquanto sujeito agente, a partir de uma teoria das condições de possibilidade da ação, mas a partir de uma lógica da paixão, uma reflexão do sujeito sobre si mesmo enquanto sujeito passional. [...] O sujeito passional não é agente, mas paciente, mas há na paixão um assumir os padecimentos, como um viver, ou experimentar, ou suportar, ou aceitar, ou assumir o padecer que não tem nada que ver com mera passividade, como se o sujeito passional fizesse algo ao assumir sua paixão. Definir o sujeito da experiência como sujeito passional não significa pensá-lo como incapaz de conhecimento, de compromisso ou ação. A experiência funda também uma ordem epistemológica e uma ordem ética. O sujeito passional tem também a sua própria força, e essa força se expressa produtivamente em forma de saber e em forma de práxis. 
Gaston Bachelard (1996), ao examinar elementos relacionados à formação do espírito científico, chama a atenção para um primeiro obstáculo que consistiria numa "experiência primeira", isenta de juízos críticos. Apesar de ser uma base insegura sobre a qual a ciência não poderia erguer suas colunas, a ausência dela provavelmente implica em mera repetição de fórmulas e dados. Há, portanto, segundo esse raciocínio, uma necessidade de se experienciar mesmo aquilo que já foi experimentado ou provado por outrem. Seria essa uma mola propulsora do espírito científico. Antonio Candido (1972), retomando as ideias de Bachelard (1996), realça outro ponto desvelado pelo filósofo francês com vistas à reflexão sobre as funções da literatura5', além de confirmar a função social da literatura (a de humanização do sujeito) e ao salientar a necessidade de ficção e fantasia presente no ser humano:

A produção e a fruição desta [da literatura] se baseiam numa espécie de necessidade universal de ficção e fantasia, que decerto é coextensiva ao homem, pois aparece invariavelmente em sua vida, como indivíduo e como grupo, ao lado da satisfação das necessidades mais elementares. E isto ocorre no primitivo e no civilizado, na criança e no adulto, no instruído e no analfabeto. A literatura propriamente dita é uma das modalidades que funcionam como resposta a essa necessidade universal, cujas formas mais humildes e espontâneas de satisfação talvez sejam coisas como a anedota, a adivinha, o trocadilho, o rifão. Em nível complexo surgem as narrativas populares, os cantos folclóricos, as lendas, os mitos (CANDIDO, 1972, p. 805).

O teatro também está nesse rol de atividades e produções humanas que atendem à necessidade de ficção e fantasia. Os jovens que se aproximam dessas formas ficcionais, teatro e literatura, provavelmente, estão em busca da humanização, da fantasia, do devaneio e do exercício imaginativo que, em outras atividades, pode se mostrar impedido, tolhido ou descartado. Travar contato com essas formas pode proporcionar, em alguma medida, uma educação sensível, experiencial, por intermédio da ficção e da fantasia que tanto a literatura quanto o teatro suscitam.

5 Interessado em estudar a formação do espírito científico, Gaston Bachelard procurou investigar como ele ia surgindo duma espécie de progressiva depuração, a partir da ganga imaginativa do devaneio, - que seria um estado de passividade intelectual a ser anulado. Mas aos poucos o devaneio lhe foi aparecendo, não apenas como etapa inevitável, ou solo comum a partir do qual se bifurcam reflexão científica e criação poética, mas a condição primária de uma atividade espiritual legítima. O devaneio seria o caminho da verdadeira imaginação, que não se alimenta dos resíduos da percepção e portanto não é uma espécie de resto da realidade; mas estabelece séries autônomas coerentes, a partir de estímulos da realidade. (CANDIDO, 1972, p. 806). 


\section{Breve relato: (futuros) jornalistas teatrando}

Uma das primeiras atividades solicitadas junto às turmas de primeiro ano de Jornalismo foi a leitura de $\mathrm{O}$ rei da vela. E, em lugar da "prova do livro", os alunos deveriam apresentar uma cena curta (com duração de cerca de dez minutos) envolvendo os personagens da peça, uma passagem escolhida a partir da leitura em diálogo com algum acontecimento jornalístico ou de repercussão na mídia. Mediante suspiros e rejeições, quase desistimos da (ousada, segundo alguns) proposta. No entanto, mediante votação, a atividade permaneceu (talvez pela aversão ainda maior à prova). Não chegamos a trabalhar com nenhum elemento teatral até o dia das apresentações. Foi uma boa surpresa: apesar de bastante nervosos, alunas e alunos se empenharam na feitura das cenas buscando utilizar recursos teatrais bastante interessantes (imagens, trilha sonora, figurinos, objetos de cena, estética melodramática ou realista, etc.). Tanto as apresentações quanto a recepção foram estimulantes. Na rodada de comentários pós-cenas, aqueles que se mostraram indispostos ante a proposta inicial chegaram a agradecer.

Num segundo momento, com essas mesmas turmas, já no segundo semestre, realizamos as leituras dramáticas de duas peças, conforme mencionado anteriormente. Um capítulo do livro A construção da personagem, de Constantin Stanislavski, sobre a leitura dramática foi sugerido como apoio e complementação. Já havíamos realizado outras leituras em sala (crônicas, poemas, contos), mas as inflexões, as intenções, a prosódia das falas se mostravam peculiares. Lidar com a voz e suas modulações, com as pausas e silêncios, com o ritmo de cada enunciado foi um aprendizado importante e difícil. Em outros momentos ficava bastante acentuada a dificuldade de lidar com o corpo. Acostumados às carteiras e à docilização, os corpos precisaram de um impulso extra por parte dos envolvidos.

Já a escuta consistiu em um dos elementos mais exercitados. O trabalho constante com a escuta do outro é, a meu ver, fundamental para a formação dos futuros jornalistas. O respeito pela narrativa do outro, pela trajetória alheia foi um dos pontos mais trabalhados durante as atividades. Um texto da docente e pesquisadora Regina Dalcastagnè (2008) se revelou interessante para a maioria, na medida em que abordava questões referentes à representatividade de minorias e de vozes ausentes no campo literário, o que propiciou um longo debate sobre as vozes que são encobertas nos discursos jornalísticos. Constantemente orientados a manter a neutralidade em seus discursos, os jornalistas precisarão muitas vezes escolher de que maneira escrever tal enunciado, de 
que modo abordar tal assunto, a quem conferir mais ou menos legitimidade. Essas foram questões que vieram à tona.

Num terceiro momento, eles apresentariam mais uma cena, agora escolhida a partir de uma lista de peças (brasileiras e estrangeiras). Concomitantemente à elaboração das cenas, marcamos uma aula no espaço-sede de um dos grupos teatrais em que realizei a pesquisa de doutorado. A ida ao teatro não era obrigatória, mas lemos um dos textos que seria apresentado pela companhia. No dia da apresentação, marcado por forte chuva, a maior parte dos alunos apareceu no teatro e tomou contato com o ambiente cênico. Não que eles já não conhecessem espaços assim, mas ali, juntos, assistindo às cenas da peça lida e comentada anteriormente, algo se operou entre nós. Uma espécie de rito, tão comum na esfera teatral.

Essa pontual ida ao teatro proporcionou experimentações mais livres nas cenas dos alunos e alunas. Alguns consideraram importante o eixo cultural e artístico perpassar as disciplinas técnicas na formação do especialista de comunicação. Lidando com o teatro alternativo, com o teatro de grupo, ainda se pôde pensar, a partir do micro, o aspecto macro das políticas públicas culturais. Em síntese, os elementos formativos mais trabalhados nessas propostas envolvendo teatro foram a escuta atenta, a leitura em roda, a disponibilidade do corpo, predisposição à ação, a instauração de um tempo mais distendido durante a encenação, recepção e debate.

\section{Considerações}

Buscando escapar da ausência de experiências significativas, simbolicamente metaforizado como o mutismo benjaminiano observado entre os jovens soldados de guerra, o trabalho envolvendo o teatro e o texto dramático ou dramatúrgico podem, assim como outras tantas possibilidades, engendrar práticas formativas válidas não só junto a artistas ou estudantes da área de Artes, mas também a alunos de outros cursos superiores (como o de Comunicação). Ou, possivelmente, em qualquer agrupamento humano. Assemelhando-se à narrativa oral passada de geração em geração, o teatro também pode consistir em importante dispositivo de manutenção, disseminação e enriquecimento desse saber proveniente da experiência coletiva. 


\section{Referências Bibliográficas}

BACHELARD, G. A formação do espírito científico: contribuição para uma psicanálise do conhecimento. Rio de Janeiro: Contraponto, 1996.

BARTHES, R. O prazer do texto. São Paulo: Perspectiva, 1993.

BENJAMIN, W. Obras escolhidas: magia e técnica, arte e política (Vol.1). $7^{\mathrm{a}}$ ed. São Paulo: Brasiliense, 1994 .

CANDIDO, A. A literatura e a formação do homem. In: Ciência e Cultura, v. 24, n. 9, São Paulo, 1972.

DALCASTAGNÈ, R. (org.). Ver e imaginar o outro. São Paulo: Editora Horizonte, 2008 .

DESGRANGES, F. Pedagogia do teatro: provocação e dialogismo. São Paulo: Hucitec, 2006.

HEIDEGGER, M. A caminho da linguagem. Petrópolis: Vozes, 2003.

LARROSA BONDÍA, J. Notas sobre a experiência e o saber de experiência. Rev. Bras. Educ. [online]. 2002, n. 19, p. 20-28. ISSN 1413-2478. 
Sendo assim, neste artigo, iremos discorrer sobre a execução dos projetos de Assessoria de Comunicação, permitindo articular teoria e prática, bem como abordar questões fundamentais para a formação do profissional de Jornalismo e de Relações Públicas.

\section{A Educação Universitária na Contemporaneidade}

A universidade, como uma instituição que deve estar aberta ao diálogo, tem o desafio de encontrar soluções concretas para o presente e o futuro, buscando atender às novas necessidades da sociedade, ou seja, preparar profissionais, levando em conta a real demanda social, com senso de justiça, visão humanística e solidária, ética e criatividade. Para Almeida e Pimenta (2011), os professores universitários são os principais responsáveis pela capacitação desses profissionais, tendo a tarefa de não só repassar conteúdos, mas também de desenvolver o caráter formativo necessário a um convívio social harmonioso.

Nessa perspectiva, a universidade necessita constituir-se numa entidade estimuladora da criatividade, na qual a análise, a investigação, a reflexão e o questionamento em geral venham a proporcionar inovações significativas em sua comunidade e em seu entorno. Para tanto, faz-se necessário que os docentes facilitem e sejam mediadores da mais ampla circulação de ideias, projetos, programas e atividades integradoras que caracterizam a complexidade e a multiplicidade do saber atual. Por consequência, os professores universitários precisam acompanhar os avanços científicos e tecnológicos, tentando repassá-los de maneira a interagir com o mundo real que se tem hoje e com as incertezas futuras.

Conforme Formosinho (2011, p. 143): “a universidade não exige apenas que se ensine e se investigue, mas que haja uma interação entre a pesquisa e o ensino de modo que os conhecimentos obtidos pela pesquisa possam ser incorporados ao ensino". Nesse sentido, as pesquisas e práticas acadêmicas irão contribuir para a qualificação, melhoria e renovação do processo de ensino-aprendizagem. Mediante a interação professor-aluno, a teoria estará articulada à prática, com uma maior capacidade de contextualizar a aplicação dos conhecimentos, a valorização de trocas de experiências e a pesquisa no âmbito acadêmico.

Morin (2001) sustenta que, se somos seres simultaneamente físicos, biológicos, sociais, culturais, psíquicos e espirituais, evidentemente a 
complexidade é aquilo que tenta articular a identidade e a diferença desses aspectos ao unificá-los por uma redução mutilante. De acordo com essa linha de pensamento, cabe à universidade oportunizar estudos que abordem a complexidade dos saberes numa visão mais ampla e mais profunda, afastando-os da fragmentação e englobando-os em atividades diversificadas que se complementam e se integram nas múltiplas dimensões epistemológicas.

Apesar dessa missão universitária, no cotidiano acadêmico, percebese que o ensino separa e isola conhecimentos, desviando os objetos de seus contextos e dividindo a realidade em disciplinas, sem estabelecer uma intercomunicação, embora existindo laços e possibilidades de interação entre as diversas áreas do saber. Morin (2006, p. 12) destaca que "o conhecimento torna-se cada vez mais pertinente quando é possível encaixá-lo num contexto mais global. Em contrapartida, se temos um conhecimento muito sofisticado, mas que é isolado, somos conduzidos ao erro e à ilusão".

No centro de todos os saberes, encontra-se a comunicação, a qual possibilita que a dialética seja substituída pela dialógica, a partir da articulação do simples com o complexo, da ordem com a desordem, do separável com o inseparável. Assim, serão separadas as especializações estanques, as quais distanciam os diferentes campos da pesquisa e impedem a sua conexão. Por essa razão, Morin (Ibidem) insiste na tentativa do salto em direção ao novo, no abandono das certezas teóricas e na busca de novos paradigmas científicos.

Com outras propostas de ensinagem, a educação se tornará mais ampla e mais profunda, não se diluirá, nem irá fragmentar o conhecimento em parcelas, uma vez que será mais abrangente e mais capaz de interpretar criativa e criticamente crises e problemas não só contemporâneos, mas também futuros. Em vista disso, o sistema educativo universitário deverá cada vez mais vincular a teoria às práticas profissionais.

Reunindo o pensamento plural, multidimensional, haverá aproximações e distinções numa perspectiva do termo complexus no seu sentido original: tecido junto. Essa é a reforma do pensamento universitário e a melhor ferramenta para romper com velhos dogmas, bem como aceitar a complexidade e as incertezas, tanto em escala local e regional quanto na esfera planetária.

É necessária e importante, na educação universitária, a participação cooperativa de alunos e professores no processo de inclusão na comunidade em que cada instituição está inserida. Isso ocorre a partir da criação e difusão cultural, estímulo à pesquisa, colaboração na formação continuada de profissionais, expansão e interação de saberes, experiências culturais, técnicas e 
cientificas. Esses aspectos supõem a inclusão solidária dos envolvidos no sistema educativo ao possibilitar a concretização de melhorias sociais, culturais e econômicas, capazes de assegurar a dignidade da pessoa humana (LDB, 1996).

$\mathrm{Na}$ sociedade planetária, torna-se relevante uma ação docente diferenciada da praticada tradicionalmente nos meios acadêmicos. Almeida e Pimenta (2011, p. 24) sustentam que,

na docência, como profissional que realiza um serviço à sociedade, o
professor universitário precisa atuar de forma reflexiva, crítica e com-
petente no âmbito de sua disciplina, explicitando seus sentidos, seu
significado e sua contribuição no percurso formativo dos estudantes
e no projeto político-pedagógico dos cursos, coletivamente definido e
vivenciado no cotidiano do ensino e da pesquisa.

Essa competência leva em conta que a atuação docente necessita resultar da convergência e articulação entre as dimensões científica, investigativa e pedagógica. Sendo assim, o docente precisa estar preparado para elaborar projetos inovadores e planejar aulas com metodologias e estratégias didáticas, a fim de acompanhar e avaliar o desempenho não só intelectual dos alunos, mas também a sua prática interativa e integradora. Consequentemente, compete ao educador disponibilizar-se para as mudanças exigidas pela sociedade planetária.

Sua conduta e sua atuação profissional irão caminhar em direção a uma prática educativa comunicacional. Também, o perfil do professor não será construído no vácuo, mas na sua relação com os alunos, enquanto sujeitos comunicantes, capazes de aplicar as modernas tecnologias da informação e da comunicação, colocando a educação formal num patamar de contemporaneidade (PENTEADO, 1998). Desse modo, o professor transmissor de informações tende a ser substituído por um docente capaz de guiar e orientar o aluno para a sua função de agente da própria aprendizagem. Nesse cenário, a educação superior deverá também levar em conta aspectos formativos ao incluir mais habilidades, competências e atitudes nos seus currículos e nas práticas, tanto em sala de aula, quanto para além do mundo acadêmico.

De acordo com essa linha de pensamento, vale lembrar as palavras de Paulo Freire (1998) ao afirmar que faz parte da atuação do educador aceitar riscos e assumir-se como profissional. Com isso, criam-se condições para que o aluno possa engajar-se em experiências, comprometendo-se como ser social. Por essa razão, professores/pesquisadores têm sido chamados a trabalhar em parceria com a comunidade, proporcionando aprendizados que se realizam num processo globalizado. 
Por consequência, a educação avançará mais. Sabendo os educadores adaptar os programas às necessidades dos alunos, serão estabelecidas conexões com o cotidiano, e a sala de aula se transformará em uma comunidade de investigação na qual as contribuições serão valorizadas e desenvolvidas em conjunto. Para tanto, será indispensável traçar linhas de ação pedagógica que norteiem atividades individuais e coletivas, oportunizando a seleção de informações em espaços menos rígidos de formação profissional.

Para Morin (2000, p. 29),

a aquisição da informação, dos dados, dependerá cada vez menos do professor. As tecnologias podem trazer, hoje, dados, imagens, resumos de forma rápida e atraente. O papel do professor - o papel principal - é ajudar o aluno a interpretar esses dados, a relacioná-los, a contextualizá-los.

Portanto, ensinar e aprender requerem, no mundo contemporâneo, muito mais flexibilidade no espaço e no tempo. Sendo assim, cabe ao professor ajudar os alunos a construir um referencial rico de conhecimentos, o qual proporcione caminhos direcionados a práticas que se afastem dos paradigmas convencionais de ensino e preparem-nos para uma atuação interativa na sociedade.

\section{Educação interativa e tecnologias}

A atuação do professor baseia-se na formação e na transformação simultânea dos sujeitos e de seus entornos. Não basta o docente adotar as tecnologias como uma ferramenta de ensino com o propósito de ministrar aulas cada vez mais interessantes e ilustradas por exposições multimídia, o que importa é "mudar o paradigma educacional e concentrar-se na criação, na gestão e na regulação de situações de aprendizagem” (PERRENOUD, 2000, p. 139).

Conforme Perrenoud (2000), não mais se pode pensar numa pedagogia sem estar consciente das transformações provocadas pela informática em relação às práticas de leitura e escrita. Da mesma forma, o educador que se preocupa com a aplicação dos saberes à vida para além da universidade precisa adquirir um domínio básico das tecnologias, para que o aprender se torne mais relevante do que ensinar.

Com o uso das tecnologias, é possível reforçar a contribuição dos trabalhos didáticos, porque elas permitem criar situações de aprendizagem 
ricas, complexas e diversificadas, uma vez que a informação e a dimensão interativa são assumidas pela comunidade aprendente. Como ponto de partida, os dados obtidos nessas ferramentas podem transformar-se em conhecimento para a vida, desde que o professor os utilize como estímulo para o aluno ter autonomia na construção e reconstrução do conhecimento.

Nessa perspectiva, as tecnologias estão presentes nas atividades práticas do mundo do trabalho e tornam-se vetores de experiências do cotidiano. Além do mais, as ações midiáticas carregam consigo uma dimensão socializadora ao promoverem uma rede social complexa.

Outro aspecto relevante da atuação docente universitária refere-se à prática pedagógica aliada à crítica, o que facilita a formação dos futuros profissionais e um desempenho no sentido de uma educação integral, ou seja, mais completa. Consequentemente, faz-se necessário analisar o processo educativo atual, sobretudo quanto à socialização das novas gerações, tornando-as capazes de construir identidades sociais e culturais, produtoras de referências e de valores humanizantes.

Então, a perspectiva é a de criação de universidades nas quais o aprendizado seja reflexivo, crítico e criativo. Com base nas experiências pessoais dos acadêmicos, o educador poderá priorizar as trocas que propiciam o autoconhecimento e o conhecimento coletivo, de modo que cada um desenvolva suas competências (MORIN, 2000).

Conforme afirmam Pimenta e Almeida (2011, p. 175), cabe ao professor o papel de orientador da aprendizagem por meio de processos coletivos. "Essa proposta pressupõe um alargamento do espaço de ensino para além da sala de aula; pressupõe um trabalho que integra saberes de diferentes origens; de diferentes disciplinas; de diferentes espaços; pressupõe a pesquisa e a extensão". Assim, a sala de aula sai dos muros acadêmicos universitários e considera a construção de conhecimentos, por meio da mediação, da criatividade, da prática dialógica, da ressignificação de saberes e dos processos emocionais, afetivos e sociais.

Dessa maneira, é possível refletir sobre a articulação entre educação e tecnologia, uma vez que o sistema educativo está em permanente estado de transformação, de modo especial nos últimos anos. Em síntese, cabe ressaltar que as estratégias de aprendizagem e ensino precisam adaptar-se à nova realidade, já que os mecanismos de transmissão e os agentes transmissores não são mais os mesmos, nem as oportunidades e os espaços. Logo, os educadores farão a transição nas formas de lidar com o conhecimento e a informação nos meios educativos, especialmente, nos acadêmicos. 


\section{Comunicação Organizacional - funções, atribuições e contribuições}

Com relação à Comunicação Organizacional, pode-se dizer que ela é aquela que ocorre dentro de todas as organizações e envolve todo o processo de comunicação das mesmas com seus mais diversos públicos. Para Margarida Kunsch (2003), a Comunicação Organizacional abrange a comunicação institucional, a comunicação mercadológica, a comunicação interna e a comunicação administrativa, mas destaca:

Trata-se, na verdade, da comunicação "corporativa", que no Brasil, em grande parte, ainda se chama de comunicação "empresarial". Ao nosso ver, o termo comunicação "organizacional", que abarca todo o espectro das atividades comunicacionais, apresenta maior amplitude, aplicando-se a qualquer tipo de organização - pública, privada, sem fins lucrativos, ONGs, fundações, etc., não se restringindo ao âmbito do que se denomina "empresa" (KUNSCH, 2003, p.150).

No que se refere ao conceito da Comunicação Organizacional ou Empresarial, Francisco Gaudêncio Torquato do Rego (1986, p. 114) afirma que:

a Comunicação Empresarial não envolve apenas as formas, os recursos e os canais de comunicação coletiva - Relações Públicas, Jornalismo, Propaganda, Editoração, Identidade Visual, sistemas de informação. Abarca as comunicações humanas, interpessoais, grupais. Abrange as comunicações administrativas - os fluxos, as redes, o volume de papéis normativos, os climas sócio organizacionais. Integrar tais circuitos, torná-los sinérgicos - é a principal estratégia dos novos tempos.

Dentro da perspectiva da Comunicação Organizacional está a comunicação integrada, ou seja, a sinergia de todas as áreas da Comunicação, respeitando as suas peculiaridades, baseando-se em uma política global, definida com ações estratégicas de comunicação. Para Lattimore (2012), os departamentos de comunicação das corporações geralmente cuidam das relações com a mídia, da gestão de crises, do assessoramento da administração superior sobre questões de reputação e gestão de longo prazo, mas trabalhos como mídia, publicidade de produtos, gestão de eventos e algumas ações de relações com a comunidade costumam ser terceirizados.

Lattimore (2012) também destaca que, com os novos mercados globais e uma constante cobrança com relação à responsabilidade organizacional, algumas funções dos profissionais de comunicação estão mudando, tais 
como: das assessorias externas ao consultor de comunicação interno; da comunicação unidirecional à comunicação bidirecional e à interação; do apoio ao marketing à comunicação integrada; do programa ao processo; do artesão da mídia ao planejador de comunicação; dos itens de curto prazo ao desenvolvimento de relações de longo prazo; de bombeiros a gestores de crises; da manipulação ao entendimento, negociação e compromisso.

Usando a comunicação bidirecional, os profissionais agora esperam que suas iniciativas de comunicação resultem em ganhos de conhecimento, entendimento e outros efeitos cognitivos de ordem superior que tenham maior probabilidade de servir de base para relações de longo prazo. Como os princípios de comunicação bidirecionais implicam que cada grupo ou lado entenda o ponto de vista do outro, o processo tem maior probabilidade de levar à negociação, ao compromisso e a uma série de resultados em que todos tenham a ganhar (LATTIMORE, 2012, p. 378).

Nesse sentido, o assessor de imprensa/comunicação necessita compreender a relevância de sua função comunicacional, sendo ético e levando em conta que se trata de uma atividade em crescente expansão. Ele desempenha um importante papel de intermediação no relacionamento com os outros meios de comunicação, possuindo as ferramentas necessárias para interagir junto aos mais diversos públicos. Por isso, não é somente um facilitador, mas, principalmente, um agente de mudanças que seleciona e avalia temas relevantes para seu assessorado, com o propósito de transformá-los em notícias ou outro tipo de material de divulgação.

Portanto, para que a atuação desse profissional se desenvolva de forma eficaz e criteriosa, é preciso uma constante atualização por meio da formação continuada. Isso porque a assessoria de comunicação é um campo que exige resultados concretos em relação à melhoria da reputação do assessorado, que busca os serviços dos assessores em função de uma realidade de acirrada concorrência e de ampla liberdade de opinião e comunicação. Sendo assim, torna-se indispensável criar para a organização uma imagem pública consolidada e sustentável.

A atividade de assessoria de comunicação é fundamentada no planejamento. E, segundo Kunsch (2003), um processo de planejamento é composto por doze etapas independente da área ou situação: identificação da realidade situacional; levantamento de informações; análise dos dados e construção de um diagnóstico; identificação dos públicos envolvidos; determinação de objetivos e metas; adoção de estratégias; previsão de formas 
alternativas de ação; estabelecimento de ações necessárias; definição de recursos a serem alocados; fixação de técnicas de controle; implantação do planejamento; e avaliação dos resultados.

\section{Procedimentos Metodológicos}

Com o intuito de vincular as teorias estudadas à prática profissional, as autoras deste texto propuseram, nas disciplinas de Assessoria de Imprensa e de Assessoria de Comunicação, ministradas respectivamente nas Universidades Federais de Pelotas e do Pampa, que os acadêmicos se dividissem em grupos para elaborar um projeto de Assessoria de Comunicação que seria executado em organizações com ou sem fins lucrativos.

Visando à integração entre as práticas a serem desenvolvidas nas disciplinas, as docentes mantiveram o diálogo e a discussão sobre os conteúdos e ações desenvolvidos nas disciplinas. Vale destacar que uma das preocupações do trabalho integrado foi em relação à observação permanente de que as universidades apresentam grande diversidade e particularidades, e isso precisa ser respeitado. Uma das questões que une os cursos de Jornalismo, 2009, e Relações Públicas, 2010, destas instituições é seu pouco tempo de funcionamento. Neste sentido, seus currículos e ementas estão atualizados e visam à formação de egressos que, entre outras habilidades, saibam refletir sobre a variedade e mutabilidade de demandas sociais e profissionais, contemplando problemáticas decorrentes da globalização, das tecnologias de informação e comunicação, do desenvolvimento sustentável e de cidadania, necessárias à sua atuação.

Neste sentido, foram trabalhados nas disciplinas os conteúdos teóricos concernentes às atividades, atribuições e funções do assessor de comunicação, bem como os instrumentos e ferramentas utilizadas por este profissional em sua atuação. Uma das principais responsabilidades da assessoria de comunicação é o relacionamento com os veículos de comunicação social, abastecendo-os com informações relativas ao assessorado (através de releases, press-kits, sugestões de pautas e outros produtos), intermediando relações de ambos e atendendo às solicitações dos jornalistas de quaisquer órgãos de imprensa (FERRARETO; KOPPLIN, 2000).

Após a etapa teórica, cada grupo apresentou sua proposta de trabalho a uma empresa ou instituição na qual iria desenvolver diferentes atividades e ferramentas de comunicação. Cada grupo iniciou seu trabalho com a 
realização dos diagnósticos de comunicação das empresas ou instituições. A partir da elaboração dos diagnósticos, foram discutidas as estratégias de trabalhos e feitos os planos de ação para implementar os procedimentos, com vistas a uma melhor comunicação entre os públicos, clientes e imprensa.

Com relação aos objetivos, buscou-se despertar nos acadêmicos a compreensão do papel do profissional de comunicação no exercício da função de Assessor de Comunicação, enquanto ação estratégica, ligada ao processo de comunicação de uma organização e do gerenciamento da mesma com seus diversos públicos. Também, pretendeu-se promover, gerenciar e administrar uma interface de comunicação entre fonte/assessorado/públicos, possibilitando trocas comunicacionais, além de fortalecer a imagem institucional da empresa/ instituição por meio da veiculação de informações de caráter jornalístico de interesse para a comunidade em geral ou para públicos especializados nas mídias.

Para a consecução dos objetivos, levando em conta os diagnósticos, cada grupo estudou e pesquisou instrumentos, ferramentas e estratégias de ação que pudessem ser aplicados de acordo com a realidade organização/ instituição. Dessa forma, as ações empreendidas seguiram um cronograma, sendo executadas sob a supervisão das autoras deste trabalho.

\section{Breve comentário acerca dos trabalhos realizados pelos acadêmicos}

Cada um dos grupos, depois de executados os projetos, elaborou um relatório e apresentou, oralmente e com o auxílio de recursos audiovisuais, relatos e comentários sobre as atividades desenvolvidas em cada organização/instituição, enfatizando o significado e a importância da realização dessa tarefa teórico-prática. A apresentação foi feita em sala de aula, contando com a presença dos colegas, do professor responsável pela disciplina e de professores convidados para fazer a avaliação do desempenho dos acadêmicos envolvidos nesse projeto.

Todos os grupos, além de utilizar os instrumentos próprios de Assessoria de Comunicação, como release, press-kit, mailing list e clipping, também trabalharam com redes sociais, criaram sites e vídeos institucionais, realizaram eventos, objetivando angariar parcerias, divulgar as ações desenvolvidas pelas organizações/instituições e realizar promoções de acordo com as datas comemorativas do semestre. 
A experiência de Assessoria de Comunicação foi tão significativa e proveitosa para os acadêmicos e para as organizações envolvidas que alguns grupos foram convidados a continuar desenvolvendo essa função como voluntários e outros como estágio remunerado. Isso foi divulgado nos cursos e trouxe repercussões positivas para o contexto universitário, ao evidenciar que a Universidade, dialogando com a sociedade e a ela prestando seus serviços, viabiliza uma maior integração com diferentes públicos e realiza a difusão das ações prestadas.

Alguns grupos, observando as necessidades e carências das organizações sem fins lucrativos, promoveram eventos na comunidade e no ambiente acadêmico. O objetivo era buscar um número maior de apoiadores e mais incentivos e estímulos a essas instituições que empreendem trabalhos comunitários/sociais, nem sempre socializados ou propagados.

Outro aspecto a ser considerado foi a visibilidade dada às diferentes instituições escolhidas, uma vez que a maioria delas não possui Assessoria de Comunicação nem condições para contratar serviços de comunicação de maneira formal e remunerada. Consequentemente, o canal de comunicação entre o assessorado e seus públicos estava defasado ou nem sequer existia. Portanto, com a execução destes projetos, as instituições contempladas tiveram a divulgação de uma imagem positiva e se tornaram mais conhecidas social e virtualmente. Para os alunos, esse tipo de experiência prática proporcionou mais uma oportunidade de demonstrar/desenvolver envolvimento, proatividade e responsabilidade.

\section{Considerações Finais}

No presente artigo, buscou-se registrar o trabalho executado por acadêmicos - de Jornalismo, da disciplina Assessoria de Imprensa, da Universidade Federal de Pelotas; e de Relações Públicas, das disciplinas Assessoria de Comunicação I e II, da Universidade Federal do Pampa (Campus São Borja) -, que vivenciaram formas diferenciadas de aprendizagem no ensino superior a partir da articulação entre as teorias estudadas e a prática cotidiana. A partir dos referenciais teóricos utilizados, percebeu-se a relevância da pesquisa de diferentes autores para que ocorram mudanças expressivas na área educacional, especialmente em nível universitário.

Nesse contexto, observou-se a importância de lançar desafios aos acadêmicos no sentido de aplicarem seus conhecimentos, instrumentos e 
ferramentas de comunicação para além da academia, adotando tecnologias da informação e comunicação. Isso porque a educação formal não pode estar à margem dos avanços tecnológicos que perpassam os diferentes grupos sociais, necessitando repensar a sua lógica, a fim de acompanhar a velocidade com que as transformações acontecem.

Sendo assim, o sistema educativo necessita adotar o agir comunicativo como estratégia de formação de profissionais autônomos, críticos e criativos, tornando-se capaz de contemplar a complexidade da comunicação na efetiva atuação social. Foi por essa razão que se executou o projeto de Assessoria de Comunicação, cujos resultados demonstraram a importância do diálogo entre a Universidade e a comunidade na qual esta se encontra inserida.

A partir da realidade vivenciada pela sociedade, os cursos universitários precisam adaptar-se ao paradigma do conhecimento, promovendo mudanças nas suas metodologias, ritmos e modos de produzir e divulgar o saber. Ao incorporar novas tecnologias e diferentes formas de aprender, o ensino superior assume um posicionamento de crítica e compromisso que envolve todos os sujeitos num processo participativo. Todavia, participar de uma dinâmica de transformações não consiste em tarefa fácil, mas urgente, numa instituição cuja proposta é produzir conhecimentos contextualizados. Por esse motivo, a universidade carece permanentemente de desafiar a si própria e aos seus membros.

Essa é razão principal deste artigo, que expôs um trabalho levado a efeito por estudantes dos cursos de Jornalismo e Relações Públicas. Os objetivos atingidos explicitaram a pertinência desse tipo de prática. Essas atividades valorizaram as instituições e organizações locais ao demonstrarem que tais procedimentos necessitam ser incentivados, apoiados, cultivados, valorizados e socializados. 


\section{Referências}

ALMEIDA, M. I. de. Pedagogia Universitária: Caminhos para a formação de professores. São Paulo: Cortez, 2011.

CARVALHO, C.; REIS, L. M. Manual Prático de Assessoria de Imprensa. Rio de Janeiro: Elsevier Editora, 2009.

DUARTE, J. (Org.). Assessoria de imprensa e relacionamento com a mídia: teoria e técnica. São Paulo: Atlas, 2002.

FERRARETO, L. A.; KOPPLIN, E. Assessoria de Imprensa: teoria e prática. $3^{\text {a }}$ edição. Porto Alegre: Sagra DC Luzzatto, 2000.

Federação Nacional dos Jornalistas. FENAJ. Manual de Assessoria de Comunicação. 4 Edição. Revista e Ampliada. Brasília, 2007.

FORMOSINHO, J. Dilemas e tensões da atuação da universidade frente à formação de profissionais de desenvolvimento humano. In: PIMENTA, S. G.; ALMEIDA, M. I. Pedagogia Universitária: caminhos para a formação de professores. São Paulo: Cortez, 2011.

FREIRE, P. Pedagogia da autonomia. 9 Ed. Rio de Janeiro: Paz e Terra, 1998.

KUNSCH, M. M. K. Planejamento de relações públicas na comunicação integrada. 4 ed. São Paulo: Summus, 2003.

LATTIMORE, D. et al. Relações Públicas: profissão e prática. $3^{\mathrm{a}}$ ed. Porto Alegre: AMGH, 2012.

MORAN, J. M. Novas tecnologias e mediação pedagógica. Campinas, SP: Papirus, 2000 .

MAFEI, M. Assessoria de Imprensa: como se relacionar com a mídia. São Paulo: Contexto, 2004.

MORIN, E. Os Sete Saberes Necessários à Educação do Futuro. São Paulo: Cortez, Brasília, Unesco, 2001.

Complexidade e Transdisciplinaridade: a reforma da universidade e do ensino fundamental. Natal: EDUFRN, 2000. 
MORIN, E. Complexidade e ética da solidariedade. In: CASTRO, G. (coord). Ensaios da Complexidade. Porto Alegre: Sulina, 2006.

PENTEADO, H. D. (Org.). Pedagogia da Comunicação. São Paulo: Cortez Editora, 1998.

PERRENOUD, P. Novas Competências para Ensinar. Porto Alegre: Artes Médicas Sul, 2000.

PIMENTA, S. G.; ALMEIDA, M. I. de. Pedagogia Universitária: Caminhos para a formação de professores. São Paulo: Cortez, 2011.

REGO, F. G. T. do. Comunicação nas empresas modernas. In: Comunicação Empresarial, Comunicação Institucional: conceitos, estratégias, sistemas, estrutura, planejamento e técnicas. 6ª edição. São Paulo: Summus Editorial, 1986.

SCROFERNEKER, C. M. A. Trajetórias teórico-conceituais da Comunicação Organizacional. In: Revista FAMECOS, Porto Alegre, $n^{\circ}$ 31, dezembro de 2006. (.p47-53). Disponível em: <http://www.revistas.univerciencia.org/index.php/famecos/article/view/1110/832>. Acesso em 15 de jun. de 2015 . 


\title{
Educomunicação e a interface com o ensino na graduação ${ }^{1}$
}

\author{
Diva Souza Silva \\ Christiane Pitanga Serafim da Silva ${ }^{3}$
}

Universidade Federal de Uberlândia (UFU), Uberlândia, MG

\section{Educação e Comunicação no Ensino Superior}

O ensino superior tem tido desafios robustos em seu tripé universitário: ensino, pesquisa e extensão, principalmente no diálogo necessário entre esses vértices. O lócus do desenvolvimento do estudo ora apresentado é o Ensino e as possibilidades de interlocução na universidade. A formação acadêmica é imbricada de sentidos e concepções do que se ensina, como se ensina e o que isso contribui para a formação dos sujeitos.

Todos os professores foram alunos de outros professores e viveram mediações de valores e práticas pedagógicas. Absorveram visões de mundo, concepções epistemológicas, posições políticas e experiências didáticas. Através delas foram se formando e organizando, de forma consciente ou não, seus esquemas cognitivos e afetivos, que acabam dando suporte para sua futura docência (CUNHA, 2006, p. 259).

1 Trabalho originalmente apresentado no GP Comunicação e Educação do XV Encontro dos Grupos de Pesquisa em Comunicação, evento componente do XXXVIII Congresso Brasileiro de Ciências da Comunicação. Texto atualizado para esta publicação.

2 Doutora em Educação e mestre em Comunicação Social, graduada em Pedagogia. Professora da Universidade Federal de Uberlândia (UFU) na Graduação e no Programa de Pós Graduação em Tecnologias, Comunicação e Educação (PPGCE).

E-mail: diva@faced.ufu.br.

3 Doutouranda em Educação e mestre em Comunicação Social, graduada em Design Gráfico. Professora da Universidade Federal de Uberlândia (UFU).

E-mail: chrispitanga@yahoo.com.br. 
O exercício da docência na universidade é imbricado por essas visões de mundo e, consequentemente, envolvido no avanço sistemático das Tecnologias da Informação e Comunicação.

As tecnologias midiáticas perpassam os diferentes processos de educação, sendo elementos constituintes da prática cotidiana que precisam ser compreendidos e apropriados pelos docentes. A ação educativa é uma prática social, concebida coletivamente numa interlocução respeitosa entre as realidades culturais e sociais nas quais estão inseridos educadores e educandos. Nesse sentido, o saber do educando não pode ser negado, pois a construção do conhecimento é conjunta. Tal perspectiva, cuja base teórica principal encontra-se nos trabalhos de Paulo Freire (1985), reforça que os homens se educam entre si e, na medida em que constroem o conhecimento e a prática pedagógica, transformam a realidade e libertam o ser humano. Isto é,

saber que ensinar não é transferir conhecimento, mas criar as possibilidades para a sua própria produção ou a sua construção. Quando entro em uma sala de aula devo estar sendo um ser aberto a indagações, à curiosidade, às perguntas dos alunos, a suas inibições; um ser crítico e inquiridor, inquieto em face da tarefa que tenho - a de ensinar e não a de transferir conhecimento (FREIRE, 1996, p. 47).

A construção de conhecimento numa perspectiva crítica não se esvazia quando se trata de inserir Tecnologias da Informação e Comunicação (TICs) nos processos de ensinar e aprender. Tais TICs têm contribuído com a democratização do acesso ao ferramental de produção e compartilhamento de conteúdos (textos, sons e imagens) os mais diversos e para ampliar os recursos metodológicos educativos. A criação de plataformas digitais com interfaces amigáveis facilitou o manuseio de softwares e a produção de conteúdos midiáticos, que não se limita a um profissional formado na área específica, mas a qualquer indivíduo.

Castells (1999) enfatiza que a constituição das sociedades em rede vem permitindo um fluxo de informações sem precedentes. $\mathrm{O}$ acesso e o compartilhamento de informações abrem perspectivas nas mais variadas áreas, pois as novas gerações tendem a lidar com o conhecimento, dentro ou fora das instituições educacionais, através de novos suportes tecnológicos e midiáticos. A internet, por exemplo, transformou-se numa rede na qual os indivíduos passaram a se conectar não só para terem acesso a informações, mas para realizarem transações comerciais, pesquisas, entretenimento, compartilharem conteúdos, interagirem, manifestarem e expressarem opiniões. 
O fazer pedagógico deve estimular a investigação, a reflexão e a produção do próprio conhecimento pelos alunos de forma mais participativa e dinâmica. Freire (1985) destaca, em sua clássica obra Extensão ou Comunicação?, a importância da participação coletiva, da troca, do diálogo e da comunicação para a arte do ensino. Em sala de aula é cada vez mais crescente o uso das mídias, seja como recurso didático, seja como ferramentas que colaboram para a construção de um conhecimento mais amplo e multidisciplinar.

Na visão de Barbosa (2010), as tecnologias digitais são recursos mediadores a serem agregados ao processo educativo e ao projeto pedagógico das escolas. E o professor passa a atuar como uma interface do processo de interação, estimulando os alunos a utilizarem tecnologias digitais no contexto da aprendizagem. A utilização de mídias e das tecnologias digitais pelas escolas tornou-se quase um imperativo para despertar interesse nos alunos e inseri-los no processo de construção do conhecimento.

O uso fluente e especializado dos recursos de comunicação tem modificado alguns conceitos de aprendizagem, dando destaque a uma dinâmica em que o estudante demonstra maior autonomia para a experimentação, o improviso e a autoexpressão. Nesse sentido, a tecnologia se torna, igualmente, uma aliada do educador interessado em sintonizar-se com o novo contexto cultural vivido pela juventude (SOARES, 2011, p. 29).

Numa sociedade cada vez mais midiatizada e que faz uso frequente das tecnologias digitais, percebe-se que as crianças e os jovens, principalmente, assimilam os avanços tecnológicos paralelamente ao seu desenvolvimento educacional, acessando e compartilhando conteúdos a que são expostos de maneira rápida e intensa. Tal comportamento desafia profissionais de educação, comunicação e tecnologias, exigindo conformações por parte das instituições de ensino e de seus educadores para melhor compreender a realidade social de seus alunos. Portanto, para os mais jovens, meios e tecnologias são

lugares de um desenvolvimento pessoal que, por mais ambíguo e até contraditório que seja, eles converteram no seu modo de estar juntos e de expressar-se. Então, devolver aos jovens espaços nos quais possam se manifestar estimulando práticas de cidadania é o único modo pelo qual uma instituição educativa, cada vez mais pobre em recursos simbólicos e econômicos, pode reconstruir sua capacidade de socialização. Cortar o arame farpado dos territórios e disciplinas, dos tempos e discursos, é a condição para compartilhar, e fecundar mutuamente, todos os saberes, da informação, do conhecimento e da experiência das pessoas; e também as culturas com todas as suas linguagens, orais, visuais, sonoras e escritas, analógicas e digitais (MARTÍN-BARBERO, 2014, p. 120, grifo nosso). 
A pesquisa em desenvolvimento tem discutido a educomunicação e sua interface com o ensino superior a partir das práticas educativas em um curso de graduação, diante da revolução tecnológica e a relação do professor com o mundo da informação e os saberes do aluno. É importante registrar que os sujeitos pesquisadores integram um grupo de pesquisa que discute a temática, e o espaço dialoga graduação e pós-graduação.

Partindo do pressuposto de que os alunos ingressam na universidade trazendo um repertório tecnológico e certo domínio das ferramentas midiáticas, surgem algumas inquietações: para os alunos que já têm habilidade com as ferramentas midiáticas, como aproveitar os seus saberes e estimular a produção de conhecimento? Numa visão freireana, como aproveitar o repertório tecnológico dos alunos para produzir conhecimento e potencializar a aprendizagem? E ainda, como alinhar o conhecimento e experiência do professor com os saberes do aluno no processo de aprendizagem em experiências educomunicativas?

\section{Educomunicação e suas interfaces}

Uma conjugação entre educação e comunicação é a educomunicação, uma prática pedagógica que pretende estimular os processos de ensinar e de aprender, considerando os saberes dos alunos numa construção coletiva do conhecimento. Soares (2002, p. 24) apresenta uma definição de Educomunicação como "o conjunto das ações inerentes ao planejamento, implementação e avaliação de processos, programas e produtos destinados a criar e fortalecer ecossistemas comunicativos e espaços educativos presenciais ou virtuais". Articula-se a esse processo diferentes sujeitos e cenários permeados por expressões de criatividade. Para Soares (2011, p. 8),

os trabalhos em educomunicação têm hoje um papel fundamental em canalizar essas habilidades já evidentes para a produção de mídia de qualidade, marcada pela criatividade, motivação, contextualização de conteúdos, afetividade, cooperação, participação, livre expressão, interatividade e experimentação.

A Educomunicação trilha o caminho apontado pela Lei de Diretrizes e Bases (LDB) (BRASIL, 1996)4 para uma educação revolucionária,

4 Ver em BRASIL. MINISTÉRIO DA EDUCAÇÃO E CULTURA. Lei das Diretrizes e Bases da Educação Nacional. Brasília, 1996. Disponível em: <http://portal.mec.gov.br/ arquivos/pdf/ldb.pdf>. Acesso em: 15 ago. 2014. 
que compreenda e respeite a trajetória do aluno, que caminhe no mesmo ritmo do mundo e acompanhe as transformações ocorridas no ambiente onde o aluno se insere. Uma educação pautada pela pedagogia de projetos, pela interdisciplinaridade, buscando despertar e valorizar as habilidades e competências. Essa concepção de educação exige ousadia e criatividade de professores e alunos, numa constante preparação pessoal que visa à solução de problemas que surgem a partir da própria prática social.As perspectivas teórico-metodológicas desse novo campo do saber apontam para ações de intervenção social. Assim, as ações oriundas dos projetos são reunidas em seis áreas de intervenção: educação para a comunicação; expressão comunicativa através das artes; mediação tecnológica nos espaços educativos; pedagogia da comunicação; gestão da comunicação nos espaços educativos; e reflexão epistemológica sobre a própria prática.

A práxis social é a essência das práticas educomunicativas, isto é, para a educomunicação não importa o ferramental tecnológico ou a mídia utilizada, mas se o processo de mediação promove o diálogo social e educativo. De acordo com Martín-Barbero (apud SOARES, 2011, p. 43), "o desafio que o ecossistema comunicativo coloca para a educação não se resume apenas à apropriação de um conjunto de dispositivos tecnológicos (tecnologias da educação), mas aponta para a emergência de uma nova ambiência cultural". Na verdade, interessa à educomunicação o uso que as audiências/receptores dos meios de comunicação fazem dos conteúdos compartilhados, como reagem e articulam as informações e ressignificam o seu cotidiano e as suas relações sociais.

É desse encontro de sujeitos à busca da significação do significado, momento particular de ativação dos princípios da reciprocidade, ou da retroalimentação, que os atos comunicativos ganham efetividade, conquanto sustentados por mediadores técnicos ou dispositivos amplificadores do que está sendo enunciado (CITELLI; COSTA, 2011, p. 64).

A educomunicação é um processo de aprendizagem que parte dos saberes e fazeres que o aluno traz consigo, coloca-o em contato com outros saberes e, por meio da prática social (ações de intervenção social), busca ressignificar esses saberes e fazeres. O caráter transformador da educomunicação consiste em possibilitar o acesso dos jovens ao mundo da comunicação e de suas tecnologias, dentro de uma perspectiva a serviço do bem comum e da prática da cidadania (SOARES, 2011). Os projetos educomunicativos estimulam a criatividade dos jovens, ampliam o vocabulário, instigam a participação e a visão crítica do mundo. 
Ao vislumbrar a educomunicação como uma possibilidade teórico-metodológica na formação dos sujeitos, surgem outras questões: de que forma as práticas sociais podem redefinir o repertório tecnológico? Essas práticas sociais provocam alguma intervenção no curso, nas práticas educativas? Dessa forma, aponta-se uma hipótese: se a educomunicação, como prática educativa e social, parte do pressuposto que os alunos possuem repertórios e habilidades (saberes e fazeres), então os saberes em movimento que amalgamam a formação dos sujeitos pode ocorrer pelas ressignificações dos saberes por meio das relações sociais estabelecidas no processo de ensino e de aprendizagem.

\section{Os percursos da pesquisa}

A pesquisa se insere no Grupo de Pesquisa “Tecnologias da Informação e Comunicação na Educação” ligado ao Programa de Pós-Graduação em Tecnologias, Comunicação e Educação da UFU. O esforço tem sido em propiciar o diálogo entre a pós-graduação e a graduação na construção de processos de pesquisa que envolva a educomunicação cada vez mais.

No curso de graduação, é ofertada a disciplina Comunicação e Educação, que, juntamente com a disciplina Mídias e Comunicação, realiza um trabalho interdisciplinar em que os alunos elaboram e vivenciam práticas educomunicativas no desenvolvimento de um trabalho educomunicativo em ambientes escolares ou comunidades, grupos sociais ou culturais. A relação com as duas disciplinas tem possibilitado o desenvolvimento de postura crítica de conhecimento, pois relaciona teoria e prática a partir do envolvimento com uma realidade e a construção coletiva e cooperativa de compreensão dessa realidade a partir de uma intervenção educomunicativa.

É uma vivência de uma proposta teórico-metodológica na qual os graduandos têm a possibilidade de se envolverem como atores também desse processo. As ementas das disciplinas estão assim constituídas através das respectivas Fichas de Disciplinas (PPC, 2009):

Comunicação e Educação

A demanda do mundo contemporâneo por educação e comunicação. A constituição do campo de estudos da Educomunicação. A interface educação/comunicação e seus reflexos nas práticas educativas e na formação de professores. 


\section{Mídias e Comunicação}

Conceitos de Comunicação e suas áreas de confluência. Introdução conceitual sobre Jornalismo, Publicidade, Rádio e TV, Relações Públicas e sobre as mídias impressas, eletrônicas e digitais. Jornalismo e Responsabilidade Social. Os meios de comunicação e o jornalismo no Brasil. Introdução à linguagem Jornalística.

O objetivo principal desse trabalho interdisciplinar é despertar no aluno a consciência da intervenção social da prática profissional por meio da educomunicação, considerando suas habilidades e competências. Esse trabalho contempla um dos âmbitos da educomunicação na prática educativa ao propor que "os educandos se apoderem das linguagens midiáticas, ao fazer uso coletivo e solidário dos recursos da comunicação tanto para aprofundar seus conhecimentos quanto para desenhar estratégias de transformação das condições de vida à sua volta” (SOARES, 2011, p. 19).

Essa relação envolve os saberes e fazeres pedagógicos e, por isso, a compreensão das concepções de educação que orientam essas práticas. Compreender as concepções de educação que orientam as abordagens do ensinar, do aprender, de aluno, professor, conhecimento, sociedade, são fatores que desvelam a aposta educativa que se assume, de acordo com Mizukami (1986) e Libâneo (1994). As abordagens do processo de conhecimento refletem valores e concepções que dão significado ao fazer e ao sentido atribuído a essa formação em que educadores e educandos se envolvem.

Diante do objeto de investigação, a abordagem de pesquisa que melhor dialoga com os propósitos apresentados é a qualitativa. Bogdan e Biklen (1994, p. 49) afirmam que "a investigação qualitativa exige que o mundo seja examinado com a idéia de que nada é trivial, que tudo tem potencial para constituir uma pista que nos permita estabelecer uma compreensão mais esclarecedora do nosso objeto de estudo". Denzin e Lincoln (2006) afirmam que a pesquisa qualitativa consiste em um conjunto de práticas materiais e interpretativas que dão visibilidade ao mundo.

Nesse nível, a pesquisa qualitativa envolve uma abordagem naturalista, interpretativa, para o mundo, o que significa que seus pesquisadores estudam as coisas em seus cenários naturais, tentando entender, ou interpretar, os fenômenos em termos dos significados que as pessoas a eles conferem (DENZIN; LINCOLN, 2006, p. 17).

Metodologicamente a pesquisa tem se firmado nessas bases qualitativas e procedimentos de análise de conteúdo do Projeto Pedagógico do Curso, dos Planos das Disciplinas, da Proposta Educomunicativa e o desenvolvimento 
dessas etapas durante o semestre letivo. Segundo os procedimentos adotados, a pesquisa é documental, pois deverá consultar documentos que ainda não receberam um tratamento analítico, mas que são relevantes para cumprir os objetivos propostos (GIL, 2008). Para Bardin (2002, p. 38) “a análise de conteúdo é um conjunto de técnicas de análise das comunicações que utilizam procedimentos sistemáticos e objetivos de descrição do conteúdo das mensagens". Assim, estão sendo consultados os seguintes documentos: as Diretrizes Curriculares do curso (BRASIL, 2014), o Projeto Pedagógico do Curso, os planos de ensino e cronogramas das disciplinas envolvidas nas práticas educomunicativas, o roteiro dos projetos e os produtos educomunicativos resultantes do processo. Os mesmos têm sido analisados no sentido de compreender o processo da Educomunicação na formação acadêmica. Com a coleta de dados, categorias têm emergido para que auxilie melhor no processo investigativo, em consonância com os objetivos propostos.

A partir dessas análises, procedem-se as entrevistas narrativas onde os envolvidos se constituem a partir das narrativas. Para Bolívar (2001, p. 220), "a narrativa é uma estrutura central no modo como os seres humanos constroem o sentido. O curso da vida e a identidade pessoal são vividos como uma narração." Esse procedimento compreende mais diretamente os envolvidos no processo educomunicativo na tentativa de compreender como ocorre o processo, em que medida há a ressignificação dos saberes e fazeres dos alunos, ou seja, em que os projetos educomunicativos, como processo de aprendizagem, acrescentam/modificam os seus saberes. Da mesma forma serão entrevistados alguns membros das comunidades onde são realizados os projetos, para saber se ocorreu e em que medida ocorreu a intervenção social.

Um procedimento paralelo é a entrevista em profundidade no sentido de uma conversação orientada, em que os objetivos e os procedimentos metodológicos devem ser bem definidos para validar as informações coletadas. Trata-se de uma "técnica qualitativa que explora um assunto a partir da busca de informações, percepções e experiências de informantes para analisá-las e apresentá-las de forma estruturada" (DUARTE; BARROS, 2012, p. 62). Esta técnica foi escolhida justamente pela flexibilidade e por explorar, ao máximo, determinado tema, permitindo ao entrevistado liberdade para abordar os temas investigados. Dessa forma, pretende-se entrevistar o(a) coordenador(a) do curso e os(as) professores(as) das disciplinas que utilizam a prática educomunicativa para compreender como se estabelece a interface entre educação e comunicação, como são planejados e elaborados os projetos 
educomunicativos e quais são os resultados esperados dessa prática. Todos os procedimentos contemplam as questões éticas de pesquisa.

As entrevistas narrativas e em profundidade procuram investigar e compreender a educomunicação como processo e metodologia na formação do saber dos acadêmicos. Saberes mobilizados e articulados com outros conhecimentos, bem como perceber se as práticas sociais dos projetos contribuem para o repertório crítico, de conteúdo e tecnológico dos estudantes. Para Bruner (1997, p. 34), "a narrativa é um modo de pensamento, pois ela se apresenta como princípio organizador da experiência humana no mundo social, do seu conhecimento sobre ele e das trocas que ele mantém”.

Os procedimentos em movimento tendem a levar à compreensão do cenário educomunicativo de forma mais ampla, requerendo dos pesquisadores uma imersão no campo e na análise de como acontece a intervenção social das práticas educomunicativas e sua possível contribuição na formação dos sujeitos atores do processo.

A pesquisa tem sido desenvolvida há dois anos e os processos metodológicos empreendidos no sentido de compreender as narrativas dos atores dos projetos educomunicativos envolvidos. As práticas têm sido caracterizadas e analisadas para que possam ser melhor compreendidas e forneçam subsídios para a área na interlocução da Comunicação e Educação.

Até o momento, duas turmas, com média de 38 acadêmicos, foram acompanhadas. Através de procedimentos éticos, as pessoas são convidadas a participar da pesquisa ${ }^{5}$ e autorizam o acompanhamento dos projetos e as diferentes formas de interlocução midiática para esse desenvolvimento.Silva (2015), em pesquisa desenvolvida a partir de acompanhamento de uma das turmas que vivenciou essa experiência na graduação, evidenciou o caráter coletivo e colaborativo construído.

Um grupo de acadêmicos organizou um projeto orientado com bases teóricas sobre processos educomunicativos. Iniciaram a construção coletiva e colaborativa do processo de forma dialética com uma comunidade externa à universidade, buscando caracterizar os sujeitos envolvidos e a identidade dessa comunidade para eles mesmos e para a sociedade.

Esse processo se deu quando duas disciplinas de graduação realizaram um trabalho interdisciplinar em que os grupos de alunos deveriam, em uma imersão nos estudos de Educomunicação e Mídias, desenvolver um projeto

5 Termo de Consentimento Livre e Esclarecido (TCLE) 
em alguma comunidade fora da universidade. A partir dessas orientações, de forma coletiva e colaborativa, uma temática macro foi escolhida para orientar essa relação com a comunidade: Brasilidade. Os grupos se organizaram, e um deles escolheu trabalhar com a comunidade nordestina que vive na cidade de Uberlândia, MG. Junto a essa comunidade foi vivenciado um processo educomunicativo com narrativas e construção de um produto midiático ${ }^{6}$ que revelou de certa forma esse ambiente de aprendizagem mútua e significativa.

Em um dos trechos de entrevista com acadêmicos desse grupo, Silva (2015) destaca um relato:

Pra mim, eu acho que o projeto, o trabalho, foi muito gratificante e trouxe muito mais coisas pra gente do que pra eles, porque foi um enriquecimento cultural e... não só de aprender e absorver a outra cultura, de conhecer o outro, mas, principalmente, de construir tudo isso junto com eles; foi muito importante e muito enriquecedor, mesmo, e, agora, principalmente, com esta questão eleitoral... eu só lembro do trabalho que a gente fez. Nossa! A gente trabalhou com eles, vem tudo à tona... aí eu vejo como foi importante pra gente ter embasamento pra discutir, principalmente essas questões agora; então acho que foi mais importante pra gente do que pra eles.

O próprio desenvolvimento do trabalho permitiu, através das narrativas empreendidas, que a comunidade envolvida se percebesse como atores do processo e com autonomia da construção do próprio espaço de debates. O momento do país também foi favorável a muitas reflexões, pois se vivia um contexto de eleições políticas para escolha de presidente da República, senadores e deputados.

E, também, no último dia que a gente foi pra filmar e tirar foto, tinha alguns nordestinos que a gente ainda não tinha conhecido; que a gente conheceu lá na hora; e eles tinham comentado que eles nunca tinham se reunido antes pra discutir daquela forma como a gente tinha discutido aquele dia; e aí ficou aquela expectativa que depois que a gente saísse eles continuassem discutindo, mesmo que talvez, sei lá, não construíssem outro lugar ou que não fizessem algum projeto, mas que eles continuassem debatendo sobre. A gente falou sobre política, falou sobre a própria questão deles, cultural, [...] sobre os costumes.

A possibilidade educomunicativa de se constituir a partir de narrativas foi e é um espaço frutífero para relações múltiplas entre povos, culturas e maneiras de ser e viver em um país tão diverso.

6 WebDocumentário: Uai, aqui é Nordeste <https://youtu.be/oakTYDZv6oY> e página em rede social <https://www.facebook.com/uaiaquienordeste>. 
Com os dados coletados até o momento e as primeiras sistematizações, considera-se que o mapeamento das experiências educomunicativas está em fase de elaboração. A intenção é evidenciar categorias para análise que emergirem dos dados e contextos envolvidos em todos os projetos vivenciados até agora.

\section{Considerações}

A educomunicação possui, em sua essência, pressupostos que visam a superar possíveis limites conceituais entre as áreas da educação e da comunicação, configurando-se como a interface entre estes campos. A educomunicação contribui para uma educação significativa que compreenda e respeite a trajetória dos sujeitos envolvidos e promova ressignificações dos seus saberes, pois as práticas educomunicativas pretendem estimular a aprendizagem, aproveitando os saberes dos sujeitos numa construção coletiva do conhecimento.

A educação enquanto ação comunicativa é um fenômeno que permeia todas as maneiras de formação de um ser humano e, assim, sob a mesma ótica, toda ação de comunicação tem, potencialmente, uma ação educativa. Nesse sentido, a construção de uma comunicação dialógica e participativa no ambiente educacional, pautada em uma eficaz gestão compartilhada por órgãos governamentais, administração escolar, docentes, alunos e a comunidade abre oportunas perspectivas de melhoria motivacional e de fortalecimento dos laços entre alunos e professores ao longo do processo de aprendizagem.

A investigação em desenvolvimento, a partir da análise inicial de documentos e imersões em campo, tem revelado que os estudos e o empoderamento do campo de educomunicação têm contribuído para o desenvolvimento de práticas educativas críticas em diferentes espaços e ampliado o diálogo entre educação, comunicação e Tecnologias da Informação e Comunicação, tanto na graduação como em outras modalidades de educação.

Utilizando o conceito de empoderamento, Paulo Freire destaca o papel fulcral da Educação, para promover práticas sociais contribuintes da construção do capital cultural de grupos, cuja cultura socialmente legitimada ainda não tenha sido incorporada. Para Freire é por meio da práxis que se efetiva a cidadania (PESCE, 2013, s/p).

Os estudantes do curso têm vivenciado, há pelo menos dois anos, a proposta educomunicativa e as vivências têm possibilitado um desenvolvimento crítico e formativo para todos os atores do processo. A pesquisa continua e pretende contribuir no cenário de processos educomunicativos como proposta teórico-metodológica no ensino superior. 


\section{Referências}

BARBOSA, R. M. Ambientes virtuais de aprendizagem. São Paulo: Penso, 2010.

BARDIN, L. Análise de conteúdo. Lisboa: Edições 70, 2002.

BOGDAN, R. C.; BIKLEN, S. K. Investigação Qualitativa em Educação. Tradução de Maria J. A.; Sara B. S. e Telmo M. B. Porto: Porto Editora, 1994.

BOLÍVAR, A. Profissão Professor: o itinerário profissional e a construção da escola. Porto Alegre: EDIPUCRS, 2001.

BRASIL. Ministério da Educação e Cultura. (1996). Lei das Diretrizes e Bases da Educação Nacional: Lei no 9394, de 20 de dezembro de 1996. Disponível em: $<$ http://portal.mec.gov.br/arquivos/pdf/ldb.pdf>. Acessado em: 15 ago. 2014.

BRASIL. Ministério da Educação e Cultura. (2013). Conselho Nacional de Educação. Câmara de Educação Superior. Diretrizes Curriculares Nacionais para o curso de graduação em Jornalismo, bacharelado. RESOLUÇÃO n ${ }^{0}$ 1, de 27 de setembro de 2013.

BRUNER, J. Atos de significação. Tradução de Sandra Costa. Porto Alegre: Artmed, 1997.

CASTELLS, M. A sociedade em rede - a era da informação: economia, sociedade e cultura - volume 1. São Paulo: Paz e Terra, 1999.

CITELli, A. O.; COSTA, M. C. C. (org.). Educomunicação: Construindo uma nova área de conhecimento. $2^{\mathrm{a}}$ ed. São Paulo: Paulinas, 2011.

CUNHA, M. I. da. O bom professor e sua prática. $18^{a}$ ed. Campinas: Papirus, 2006.

DENZIN, N. K.; LINCOLN, Y. S. O planejamento da pesquisa qualitativa: teorias e abordagens. Porto Alegre: Artmed, 2006.

DUARTE, J.; BARROS, A. (Org.). Métodos e Técnicas de Pesquisa em Comunicação. $2^{\mathrm{a}}$ ed. São Paulo: Atlas, 2012.

FREIRE, P. Extensão ou Comunicação? 8ª ed. Rio de Janeiro: Paz e Terra, 1985. 
FREIRE, P. Pedagogia da Autonomia: saberes necessários à prática educativa. São Paulo: Paz e Terra, 1996.

GIL, A. C. Como elaborar projetos de pesquisa. 4 a ed. São Paulo: Atlas, 2008.

LIBÂNEO, J. C. Didática. São Paulo: Cortez, 1994.

MARTÍN-BARBERO, J. A comunicação na educação. São Paulo: Contexto, 2014.

MIZUKAMI, M. da G. N. Ensino: as abordagens do processo. São Paulo: EPU, 1986. (Temas básicos da educação e ensino)

PESCE, L. O programa Um computador por aluno no estado de São Paulo: confrontos e avanços. Mesa redonda sobre políticas educacionais no Brasil e America Latina, do GT 16 - Educação e Comunicação. $36^{\text {a }}$ Reunião Nacional da ANPEd - 29 de setembro a oz de outubro de 2013, Goiânia-GO.

PPC. Projeto Pedagógico do Curso (2009). Minas Gerais.

SILVA, D. F. Relações dialógicas no processo de educomunicação: análise em uma rede social na internet. Dissertação - Programa de Pós-Graduação em Tecnologias, Comunicação e Educação. Universidade Federal de Uberlândia, MG. Uberlândia, 2015 .

SOARES, I. O. Educomunicação: O conceito, o profissional, a aplicação. Contribuições para a reforma do Ensino Médio. São Paulo: Paulinas, 2011.

SOARES, I. O. Gestão comunicativa e educação: caminhos da Educomunicação. In: Comunicação \& Educação, São Paulo: ECA/USP [23]. issn: 2316-9125, 2002. 


\section{Representação da literatura brasileira no jornalismo em língua alemã $\tilde{a}^{1}$}

\section{Sonia Breitenwieser Alves dos Santos Castino ${ }^{2}$ Faculdade Cásper Líbero (FCL)}

Para saber o que cada um é, são necessários ao menos dois homens.

Alberto Manguel (2008, p. 55)

\section{Introdução}

Este artigo é um desdobramento de pesquisa realizada junto ao Centro Interdisciplinar de Pesquisa (CIP) da Faculdade Cásper Líbero, em 2013. Nossa proposta foi investigar a imagem da Literatura Brasileira Contemporânea na cobertura do tema feita por periódicos representativos no cenário da imprensa na Alemanha e na Europa, como Der Spiegel, Focus, Die Welt, Die Zeit, Frankfurter Allgemeine Zeitung (FAZ) e Die Tageszeitung (TAZ), em suas versões on-line.

O que chamamos de literatura brasileira é parte de um sistema cultural multifacetado e complexo que, no caso em questão, está sendo apresentado a um segundo sistema cultural multifacetado e igualmente complexo - o germânico. Ocorre um processo de inter-relações, mas tanto um quanto o outro se identificam internamente por valores simbólicos, padrões de pensamento, maneiras de se relacionar com o real ${ }^{3}$ e por construir certa imagem do outro.

1 Trabalho originalmente apresentado no GP Comunicação e Educação do XV Encontro dos Grupos de Pesquisa em Comunicação, evento componente do XXXVIII Congresso Brasileiro de Ciências da Comunicação. Texto atualizado para esta publicação.

2 Doutora em Letras, na Área de Filologia e Língua Portuguesa, atuando na área de Língua Portuguesa em diversos cursos de Comunicação Social; docente da Faculdade Cásper Líbero.

3 Muniz Sodré (1983) define: "Cultura designará o modo de relacionamento com o real, com a possibilidade de esvaziar paradigmas de estabilidade do sentido, de abolir a universalização 
O acesso às obras brasileiras depende da disponibilidade de traduções, assim, a escolha do que traduzir, o tratamento editorial que recebe a obra e o viés dos comentários sobre ela na mídia podem revelar a imagem da literatura e, consequentemente, da cultura brasileira projetadas naquele outro país. Ao mesmo tempo, a escolha da obra a ser resenhada pelo jornalismo internacional indica postura ideológica não somente para divulgação da literatura brasileira, mas também para sua valorização.

Além dos clássicos Machado de Assis, Euclides da Cunha e Guimarães Rosa4; além do sempre best-seller Jorge Amado e do atual super best-seller Paulo Coelho que assina metade dos lançamentos brasileiros na Alemanha, segundo Michi Strausfeld, scout de literatura latino-americana da editora Fischer, vários outros escritores brasileiros têm sido citados com menos ou mais visibilidade na imprensa alemã, tais como: Clarice Lispector, Lygia Fagundes Telles, Antonio Callado, Rubem Fonseca, João Ubaldo Ribeiro, Plínio Marcos, Raduan Nassar, Milton Hatoum, Bernardo Carvalho, Chico Buarque, Paulo Lins, Patrícia Melo, Daniel Galera, Luiz Rufatto, Cuenca, Andrea del Fuego e ainda outros.

O corpus da pesquisa aqui considerado abrange quatro textos publicados nos periódicos alemães Focus, TAZ e FAZ. Versam sobre obras do brasileiro Milton Hatoum no âmbito de uma literatura que acompanhou as transformações sociais e políticas ocorridas no Brasil depois da ditadura, com formas de expressão responsivas a essa nova realidade brasileira, além de discutir a inclusão de novas vozes sociais e, muitas vezes, incorporar recursos e estratégias das linguagens das mídias. Vale ressaltar que, no contexto educacional, o autor, nos últimos anos, tem conquistado espaços, visto que passou a compor listas de leituras obrigatórias para exames vestibulares para ingresso de várias instituições de ensino superior. Tal fato mostra uma mudança na perspectiva da educação, valorizando também autores contemporâneos, além daqueles já historicamente consagrados.

A escolha de Hatoum para ser traduzido reflete a valorização também na Europa desse autor, crítico e jornalista cultural, que tem publicado textos de cunho não literário no Neue Zurcher Zeitung (NZZ), periódico de grupo suíço, com excelente circulação também na Alemanha e Áustria.

das verdades, de indeterminar, insinuando novas regras para o jogo humano".

4 Seu Grande Sertão: Veredas consta da lista dos 100 melhores livros de todos os tempos, segundo a revista FOCUS n.21, de 18/05/2002. 
Podemos levar em conta que esses textos jornalísticos na imprensa alemã, na escolha dos temas e no recorte com que os trata, refletem o repertório, interesses e preferências estéticas do público a que se destinam. A mídia sempre tem o sotaque do mercado. Um dos objetivos das resenhas é divulgar a obra para que seja consumida, para além de seu valor cultural. Há que se considerar que a obra - na materialidade do livro - será comprada/lida. A escolha do que traduzir é influenciada por esse contexto que inclui o prestígio dos autores lá fora.

Ao tratar da literatura brasileira, os jornalistas e colaboradores dos periódicos estudados deixam entrever a imagem que têm da nossa literatura e do Brasil. Em âmbito mais geral, parece-nos relevante para o estudante de comunicação discutir as imagens que um povo constrói do outro, pois pode ser um caminho para melhor entender-se. Esse exercício poderia ser feito igualmente com resenhas de obras de escritores alemães publicadas em jornais brasileiros.

A análise de conteúdo segue necessariamente paralela à análise de elementos textuais. Interessa-nos investigar, nos textos do corpus proposto, como certos processos de referenciação, como a anáfora, podem ter efeito argumentativo, uma vez que, dentro do que a língua lhe oferece, o sujeito escolhe as expressões capazes de dar conta de sua proposta de efeitos de sentido devido a certa sua intencionalidade. O material linguístico escolhido pelo sujeito para a remissão, no texto, revela-se, desse modo, parte de uma estratégia cognitiva, discursiva, com efeitos sobre o interlocutor.

Será possível vislumbrar a imagem da cultura brasileira por meio da análise da cobertura jornalística do tema específico - literatura brasileira contemporânea - e investigar estratégias discursivas específicas escolhidas pelo jornalista e seus efeitos de sentido, certamente, dirigidos a certo perfil de leitores. Assim, o jornal procura apresentar-se como quem responde a demandas, explícitas ou não, dos leitores e reflete um conjunto geral de ideias que circulam entre esses leitores.

Esse tipo de análise pode auxiliar o estudante de comunicação a perceber como a referenciação constrói o texto e o jogo de sentidos e a desenvolver as diversas competências exigidas para essa atividade cognitivo-interativa altamente complexa, que é a escrita.

\section{A Referenciação}

A língua não é mero espelho do mundo, mas se realiza em práticas sociais que constroem cognitivamente o mundo como objetos discursivos, a partir 
da experiência e da relação entre sujeitos que negociam os sentidos. "Referir não é mais atividade de etiquetar um mundo existente e indicialmente designado, mas sim uma atividade discursiva de tal modo que os referentes passam a ser objetos de discurso e não realidades independentes" (KOCH; MARCUSCHI, 1998)5. Assim, a língua não pode ser entendida como um dado que meramente designa a possível extensão referencial de nossos itens lexicais, como se eles etiquetassem o mundo fenomênico, externo. O processo discursivo da referenciação é que constrói os referentes e o faz negociando-os no desenrolar do discurso ${ }^{6}$. Isso significa que a referenciação precisa ser vista como uma atividade discursiva e não apenas textual, que acontece em situações de interação social, dentro de um grupo social, por sua vez inserido em uma cultura.

Convém aqui lembrar que, nesta pesquisa (que é um texto), iremos analisar textos sobre textos. Em cada uma dessas instâncias, trabalha-se com certa imagem da literatura brasileira contemporânea que não é dada aprioristicamente, mas é edificada pelos interlocutores e pelos textos e discursos já feitos sobre o tema.

Ingedore Villaça Koch (2008) identifica o texto como o lugar de interação de interlocutores em diálogo, sujeitos ativos na construção dos sentidos, que é uma atividade cognitivo-interativa altamente complexa e que exige diversas competências. A referenciação salienta o caráter dinâmico do processo de construção de referentes entendidos como objetos de discurso e não de objetos do mundo. No discurso, a progressão referencial se realiza de maneira extremamente variada e dinâmica, para o que se recorre a diversos processos de referenciação ainda não suficientemente estudados.

5 Essa ideia de que a realidade empírica extramental é uma construção não dada aprioristicamente, Koch e Marcuschi foram buscar em Wittgenstein, para quem o significado depende de habilidades comunicativas aprendidas no interior de uma vivência, após longo período de socialização linguística, e consequentemente o conhecimento é mediado linguisticamente, uma vez que as coisas só adquirem sentido e só são cognoscíveis na linguagem (WITTGENSTEIN, Ludwig. Investigações Filosóficas. Petrópolis: Vozes, 1994).

6 Maria Margarida Salomão ("Razão, realismo e verdade: o que nos ensina o estudo sociocognitivo da referência”, p. 158-9, in: KOCH. I. V.; MORATO, E. M.; BENTES, A. C. (orgs.). Referenciação e discurso. São Paulo: Contexto, 2005.) alerta-nos sobre o risco de postular a verdade (em suas palavras) como construção semântica, comunicativamente validada e a reduzir a verdade a mero acordo intersubjetivo. Lembra, então, a necessidade, dada a natureza essencialmente social da cognição, de que tenhamos, à disposição, âncoras materiais para as integrações conceptuais, por meio das quais rompemos as barreiras de nossa experiência mental subjetiva. 
A anáfora, aqui entendida em sentido amplo como retomada ou remissão textual, muitas vezes é feita por uma expressão nominal, usada num texto para categorizar ou recategorizar segmentos precedentes ou subsequentes, que sofrem encapsulamento. Nesses casos, temos o que Koch (2008) chama de rotulação. Os rótulos podem ser nomes genéricos (do tipo: estado, fato, fenômeno, circunstância, condição, evento, cena, atividade, hipótese, etc.). Além disso, o rótulo pode acrescentar informação e indicar o posicionamento do autor sobre o que é dito.

Koch (2008) explica que não só rotulam o que as precede ou segue (como um acontecimento, uma hipótese, uma cena), mas também criam um novo referente textual, que por sua vez passará a constituir o tema dos enunciados subsequentes.

Flusser $(1994)^{7}$ ressalta que a língua articula a essência (consciente e inconsciente) do grupo que a compartilha e materializa o espírito de tal grupo e sua visão do mundo. Mondada e Dubois (2003) já haviam proposto que os objetos de discurso devem ser entendidos como constructos culturais, resultantes das atividades da linguagem, verbais e não verbais, dentro de um tipo de versão pública do mundo. [...] Assim, as categorias e objetos de discurso são constitutivamente instáveis, sempre em processo. Por outro lado, há uma força estabilizadora quando as categorias firmam-se em protótipos e estereótipos.

O rótulo, ao mesmo tempo, tem um papel referenciador (retoma informação dada ou que pode ser inferida) e um papel predicativo (dá informação nova). Além disso, pode imprimir ao discurso uma determinada orientação argumentativa, mas cabe ao leitor reconstituir o texto encapsulado e perceber a intenção do autor do texto ao usar um, e não outro, rótulo. O rótulo faz o texto olhar para trás - é retrospectivo - para encapsular e reintroduzir como dada certa situação descrita em enunciados precedentes e espiona à frente - é prospectivo - para avaliar a situação.

É interessante notar que um rótulo pode encapsular uma porção maior ou menor de texto. Sob uma perspectiva sistêmico-funcional, Francis (2003, p. 200) afirma que a

7 Obra editada originalmente em alemão sob o título Brasilien oder die Suche nach dem neuen Menschen: Fur eine Phänomenologie der Unterentwicklung (Brasil, ou a procura de um novo homem: por uma fenomenologia do subdesenvolvimento), Bollmann Verlag, 1994. Em português, tem o título de Fenomenologia do brasileiro, organizado por Gustavo Bernardo, Rio de Janeiro: EDUERJ, 1998. 
extensão precisa do discurso a ser seccionada pode não importar: é a mudança de direção assinalada pelo rótulo e seu ambiente imediato que é de crucial importância para o desenvolvimento do discurso. Pode-se mesmo arguir que uma indistinção referencial deste tipo pode ser usada estrategicamente pelo escritor para efeitos criativos ou persuasivos.

Em sua tese de doutorado, defendida em 2005, Maria Angélica Freire de Carvalho investigou a multifuncionalidade dos rótulos, que servem como recursos de condução de tópicos e subtópicos, de progressão referencial e como forma de explicitação de pontos de vista.

Koch (2008), sob a perspectiva discursivo-argumentativa, analisa a multifuncionalidade dos rótulos, que podem ter funções cognitivo-discursivas, ligadas à memória, à interpretação de complexos e à organização textual ou à função de orientação argumentativa: meios privilegiados de condução e explicitação de pontos de vista do produtor não só no que diz respeito aos conteúdos veiculados, como também aos seus enunciadores, inscrevendo, desta forma, a argumentatividade no texto.

Koch (2008) acrescenta ainda que, ao se rotularem segmentos textuais, cria-se um novo objeto de discurso e o produtor do texto procede a uma avaliação do que foi dito nesses segmentos, com maior ou menor força argumentativa. As opiniões dos produtores do texto e as dos leitores projetados, podem alterar os sintagmas nominais encapsuladores. Assim é que: "a sinonímia por encapsulamento anafórico apresenta um ponto de vista, um modo de compreensão, de interpretação inferencialmente construída em uma interação social" (MELO, 2008, p. 89-9o, grifos nossos).

O autor do texto propõe sentidos de acordo com os conhecimentos de mundo, mas o seu interlocutor, o leitor, fará inferências também de acordo com o conhecimento que tem dos objetos do mundo. Ambos têm certa perspectiva de observação que é negociada no texto.

\section{Imagologia: imagens do Brasil}

Em textos de alemães sobre o Brasil, como já observamos em Castino (2011), surge uma imagem complexa e contraditória do país - ora como paraíso terreal - locus amoenus, ora como a negação do éden, como nas visões de horrores infernais, por exemplo, narradas por Hans Staden. Tal imagem foi construída historicamente entre os alemães a partir dos relatos dos viajantes. Temos ressaltadas as imagens de uma terra de natureza exuberante, mas 
com selvagens vivendo a barbárie de práticas primitivas. Ou temos um Brasil urbano violento ou um Brasil natural edênico. O que motiva essa polaridade, visível nessas qualificações, pode vir a ser objeto de investigação, mas foge ao escopo desta pesquisa: há uma tendência humana cognitiva e que se revela nos produtos de diferentes culturas, de categorizar a realidade a partir de opostos binários, como explica V. V. Ivanov, em Gerade und Ungerade: die Asymmetrie des Gehirns und der Zeichensysteme, publicado pela editora Hirzel, em 1983. A esse respeito, Joep Leerssen (2000) sugere mesmo que o exame da "estrutura profunda" de grande parte dos estereótipos nacionais revela que se baseiam em pares opostos, como Norte/Sul, forte/fraco, central/ periférico. Esses opostos variáveis devem ser estudados diacrônica e historicamente. As características nacionais mais imputadas exibirão uma natureza binária, capaz de atribuir características fortemente contraditórias para qualquer grupo nacional dado (que será sempre "um país de contrastes”).

No caso dos alemães, sobre o Brasil, houve no decorrer do tempo uma oscilação entre a imagem positiva e a negativa. Entre as décadas de 1950 e 1970, por exemplo, ganhou força a imagem do paradisíaco, transmutado pelo pitoresco e exótico, mais recentemente observa-se o primitivo e selvagem transmutado em violência nas grandes cidades brasileiras (embora certamente essa violência urbana seja comum a várias megacidades no mundo).

Barbosa (2010, p. 269) salienta que "a prática da literatura e por extensão também de sua crítica, abraça necessariamente o olhar do outro” (grifo nosso), e mais adiante: "a ação de olhar para o outro traz consigo sempre uma dose de estereótipos, isto é, de imagens das práticas culturais alheias que adquirem um significado determinado, cristalizam-se e passam a compor o conjunto de fatores que determinam a percepção do outro”.

Um texto tem, vocacionalmente, uma função pública. As dinâmicas de estereótipos nacionais estão vinculadas a práticas históricas, sendo assim, Joep Leerssen (2000) acredita ser possível, através dos imagotipos, ir além da análise textual imanente e chegar a uma retórica da caracterização nacional e dos estereótipos nacionais.

Isso tudo significa que os imagotipos podem ser mais do que estratégias textuais, cognitivas ou de leitura e estar vinculados não só a questões argumentativas, mas também culturais.

Recorremos a estudos no âmbito da Imagologia (CARVALHO, 1998; DEWULFE, 2001; SOUSA, 2004, 2011; ROMERO, 2005; CAMARGO, 2006; BARBOSA, 2010; SILVA, 2011) para investigar a imagem do Brasil, e por extensão, da literatura brasileira contemporânea, divulgada na imprensa alemã. 
A Imagologia - originalmente literária, pois era parte dos estudos de Literatura Comparada - é uma área do saber que investiga imagens de nações e/ ou de povos ou de grupos, veiculadas em textos literários (poéticos, de história da literatura, de crítica literária e respectivas traduções). Para Camargo (2006), trata-se da investigação da maneira como se reage, na literatura de um determinado país, à literatura e à cultura de um país estrangeiro/estranho. No entanto, ampliou-se mais recentemente o âmbito de interesse da Imagologia, que examina a imagem de países, de povos e de grupos em quaisquer textos escritos, não só literários.

Ricoeur (apud ROMERO, 2005) procura chegar à definição de termos como imagem e estereótipo, e aborda uma questão básica: como um discurso em forma de texto pode ser interpretado e como entender esse processo que culmina no leitor e nos mecanismos de que ele se vale para tornar seu o texto que lê, não como uma composição linguística autônoma, mas em conexão com um discurso vivo, o verdadeiro destino da leitura?

Em estudos de Imagologia, o termo imagem é substituído pelo termo imagotipo, quando se está falando da imagem inculcada que um povo ou país tem de outro povo ou país. Em sua maior parte, tais estudos consistem em classificar os distintos imagotipos e em investigar seu papel nos textos. Mas além da imagem inculcada do outro (heteroimagotipo), existem os chamados autoimagotipos, ou seja, a imagem inculcada de si mesmo. Ambos os tipos são interdependentes e complementares. O outro pode ser representado com características estereotipadas para acentuar sua estranheza/estrangeirice, e com isso ressaltar os valores e características atribuídas à própria nação/terra natal e de si mesmo.

Celeste Ribeiro de Sousa (2004) lembra que não só a imagem do Brasil está em textos literários alemães, mas a imagem de países e povos da Europa também aparece muitas vezes em obras da literatura brasileira, às vezes de forma distorcida ou negativa, assim como o Brasil é apresentado, por exemplo, muitas vezes como país/povo essencialmente exótico, em obras da literatura europeia.

Podemos supor que a persistência dos imagotipos, em sua antiga face ou transmutados, sirva de ponte, de acesso persuasivo aos temas que realmente interessam aos jornalistas/resenhadores. Vamos assumir a hipótese de trabalho que os imagotipos em relação ao Brasil e nossa literatura, assim como outros estereótipos, provavelmente constituem âncoras textuais necessárias para servir de apoio para a construção de novos sentidos. Mesmo ao retomá-los, os resenhadores podem usá-los para superar esses mesmos imagotipos. Vamos considerar, assim, que esses imagotipos são mais do que meras ferramentas textuais. 
Observamos em Castino (2011) a ocorrência de certos imagotipos a respeito do Brasil, os brasileiros e sua literatura, persistentes em uma mostra da produção jornalística alemã sobre os autores brasileiros. Foi constatada a presença dos seguintes imagotipos: o Brasil é o país do samba; o Brasil é um paraíso edênico, o Brasil é exótico e a literatura brasileira também; brasileiro é ignorante; o Brasil é uma terra violenta e selvagem; a mulher brasileira é bonita e sensual; brasileiro é cordial; o Brasil é o país do carnaval X o brasileiro é resultado de três raças tristes; o Brasil é um país de contrastes; o Brasil é o país da miscigenação; o Brasil é um país gigante; Só nossa língua tem a palavra saudade; o brasileiro é muito religioso ${ }^{8}$. Esse grupo foi nosso ponto de partida para as considerações aqui apresentadas.

Texto1) Imagotipo Brasil gigante. A revista Focus, de 23 de junho de 2010, publicou a notícia9 Brasilien 2013 Ehrengast der Frankfurter Buchmesse, a respeito da participação do Brasil como país convidado de honra da futura feira de Frankfurt de 2013, salientando o pequeno número de novos títulos traduzidos para o alemão em 2010. São citados, como os mais conhecidos no exterior, os autores contemporâneos Paulo Lins, Milton Hatoum, Bernardo Carvalho e Patricia Melo, o clássico Jorge Amado e o best-seller Paulo Coelho, estes já traduzidos para o alemão. Nessa matéria, o referente Brasil é retomado pelas expressões nominais: aufstrebenden Supermacht Sudamerikas (superpotência emergente da América do Sul); das bevölkerungsreichste Land Lateinamerikas (o país mais populoso da América Latina); der größte Lizenzabnehmer auf dem gesamten amerikanischen Kontinent (o maior captador [de licenças de títulos alemães] em todo o continente americano).

Texto 2) Muttersland ${ }^{1 \circ}$, Vatersverse (Terra materna, versos paternos) é o título de uma resenha de Ute Hermann, publicada no TAZ, de 10 de dezembro de 2002, sobre Dois irmãos, de Milton Hatoum, em que este autor é identificado como Der brasilianische Schriftsteller (o escritor brasileiro), e nossa história é qualificada de mutante (die wechselvolle Geschichte seines Landes). Nessa resenha, observamos a incidência de alguns imagotipos nas remissões.

8 Quero salientar que tal lista nunca teve a pretensão de ser exaustiva, e que é provisória.

9 Disponível em: <http://www.focus.de/kultur/buecher/literatur-brasilien-2013-ehrengastder-frankfurter-buchmesse_aid_522686.html>.

10 Trata-se aqui de um jogo de palavras entre Muttersland (terra de origem da mãe) e Vatersland (terra do pai), que significa pátria. A resenha está disponível em: 
O resenhador destaca as diferenças entre os dois personagens irmãos e inimigos. Omar foi criado no Brasil, logo é o que tem a maior influência dos brasileiros. Esse personagem é descrito como corajoso e audacioso, um jogador, mulherengo e poeta. É um preguiçoso, não sem inteligência, e vive como um parasita na mansão da família (no original: ist mutig und draufgängerisch, ein Spieler, Frauenheld und Poet. Er ist arbeitsscheu, nicht unintelligent und lebt als Schmarotzer in der Familienvilla). Isso sugere o imagotipo Brasileiro é indolente e malandro. Assim, o filho que ficou no Brasil reúne qualidades disfóricas, e o que cresceu fora tem as qualidades, a energia de um imigrante. (Yaqub hat die Energie des aufstrebenden Einwanderers = Yaqub tem a energia de um imigrante esforçado).

O Brasil é um país de contrastes/de divisão entre centro e periferia é o imagotipo observado mais adiante no texto:

Die Entwicklungen Brasiliens zwischen 1914 und den 7oer-Jahren - Weltkrieg, Industrialisierung, Militärputsch und Wirtschaftswunder - bilden den zeitlichen Hintergrund für das Familienleben des muslimischen Halim, der seine Frau Zana mit arabischen Versen verführte und ihr jeden Wunsch erfüllte" (= A evolução do Brasil entre 1914 e os anos 70 - guerra mundial, industrialização, golpe militar e milagre econômico - configuram o cenário temporal para a vida da família do muçulmano Halim, que conquistou sua esposa Zana com versos árabes e realizava todos os desejos dela).

Die Söhne Yaqub und Omar verkörpern die innerbrasilianische Teilung von Zentrum (São Paulo) und Peripherie (Manaus) (= Os filhos Yaqub e Omar corporificam a divisão interna no Brasil entre centro (São Paulo) e periferia (Manaus).

Surge aqui um aspecto bastante insistente em textos alemães que falam do Brasil: a violência do país, personificada por Hatoum nos desentendimentos entre os irmãos, sem dúvida, e destacada pelo resenhador.

Der Wettstreit zwischen den Brüdern spitzt sich mit dem Alter zu. Ohnmächtig vor Wut, weil der Stratege Yaqub ihn übertrumpft und kühl aus der Ferne seine Rache plant, schlägt der gewalttatige Omar den Bruder bei einem Besuch in Manaus zusammen")." (A competição entre os irmãos aguça-se com a idade. Impotente de fúria, porque o estrategista Yaqub triunfa sobre ele e friamente planeja sua vingança à distância, o brutal Omar acaba com o irmão durante uma visita a Manaus.)

Essa questão da violência e do super-realismo na literatura contemporânea tem sido apontada como característica por diversos estudiosos, 
também brasileiros, como Castro Rocha (2006). Ele propõe, para análise da sociedade brasileira e de sua produção cultural mais recente, o que ele chama de "dialética da marginalidade", "fundada no princípio da superação das desigualdades sociais através do confronto direto em vez da conciliação, através da exposição da violência em vez de sua ocultação" (ROCHA, 2006, p. 26). Nesse modelo, o termo marginal refere-se não apenas ao bandido, mas se estende aos excluídos dos benefícios do progresso social, à margem dos direitos elementares. O autor parte da análise de textos literários de Carolina de Jesus, Paulo Lins, Ferréz, André du Rap, músicas e demais manifestações artísticas em que reconhece o movimento da dialética da marginalidade, muito diferente da chamada dialética da malandragem, proposta por Antonio Candido.

Texto 3) Von Patriarchen und Indios (Sobre patriarcas e indios). Tratase de uma resenha, de Saskia Vogel, do romance Cinzas do Norte, publicada no TAZ em 11 de outubro de 2008. Já no olho da matéria, Vogel lamenta que Hatoum idealize a população indígena e critica o clichê kitsch do título em alemão: Cinzas do Amazonas" ${ }^{n}$. Nessa resenha, observamos os imagotipos: O Brasil é uma terra selvagem, "de tribos esquecidas” (no original, „irgendeinem vergessenen Indiostamm“); o Brasil é um país de contrastes (desenvolvido X subdesenvolvido, floresta $\mathrm{X}$ industrialização, produção cultural sofisticada X mudez). Vale a pena transcrevermos e traduzirmos o trecho: Aber es gibt kaum signifikante Bücher von Schriftstellern aus Amazonien selbst. Die Region scheint keine Stimme zu haben, selbst in Brasilien nicht, in dem sich die literarische Produktion vornehmlich auf den industriell hoch entwickelten Südosten konzentriert. [...] Hatoum ist einer der wenigen Schriftsteller, die die Region auf dem internationalen Buchmarkt vertreten. (No entanto, quase não há livros significativos de escritores oriundos da Amazônia. A região parece não ter voz, nem no Brasil, onde a produção literária se concentra sobretudo no Sudeste industrialmente muito desenvolvido. [...] Hatoum é um dos poucos escritores que representam a região no mercado editorial internacional).

No trecho abaixo, temos os imagotipos: O Brasil é um país exótico, selvagem e os índios têm uma inocência natural, ainda que atribuídos a Hatoum e criticados pelo comentador do texto, são ressaltados por ele e auxiliam na construção da argumentação do texto:

11 O título original de Milton Hatoum é Cinzas do Norte, o que não faria sentido para os alemães, já que em sua percepção geográfica o Norte seria o Hemisfério Norte, ou os países ao Norte da Alemanha. 
Gleichzeitig legt auch Hatoum die Außenperspektive nicht ganz ab; aus seiner privilegierten Position heraus schreibt auch er vornehmlich über statt aus dem Innern von Amazonien und betreibt eine exotische Idealisierung der indigenen Bevölkerung. So verkörpert Raimundos Mutter Alícia die angeblich existente „ungezähmte Wildheit“ Brasiliens par excellence, ihr rutscht gerne auch mal ganz kreatürlich-unbedacht der Busen aus der Bluse. (Ao mesmo tempo, Hatoum não abandona totalmente a perspectiva de fora; de sua posição privilegiada, ele também escreve principalmente sobre a Amazônia, em vez de escrever do interior da Amazônia, e aciona uma idealização exótica da população indígena. Assim, a mãe de Raimundo personifica a pretensamente existente "indômita selvageria [alma selvagem]", por excelência, do Brasil; ela gosta de deslizar o seio para fora da blusa, de forma totalmente natural e espontânea).

Saskia Vogel atribui ao romance uma grande qualidade política (große politische Qualität), a de ser de um escritor famoso, de origem "árabe", que critica direta e não apenas alegoricamente a ditadura e suas consequências ainda hoje perceptíveis e que contribui para a conscientização política do país, ao falar sobre a história. Vemos o imagotipo da violência em outra forma:

Hatoum ist neben Raduan Nassar der zweite bekannte brasilianische Schriftsteller mit arabischem Hintergrund - beide verbindet das Thema der übermächtigen Dominanz des Vaters. Doch was in Nassars Roman „Das Brot des Patriarchen" (1975) nur als Allegorie verhandelt wird, wird bei Hatoum direkt kritisiert: „Asche vom Amazonas" ist eine Anklage der Militärdiktatur, der skrupellosen Wirtschaftseliten Brasiliens, die das Land zwischen 1964 und 1985 gleichschalteten. Die Auswirkungen der Diktatur sind bis heute spürbar - ein korrupter Polizeiapparat, tägliche Verletzungen der Menschenrechte und ein brutales Vorgehen gegen Minderheiten. ("Cinzas do Amazonas" denuncia a ditadura militar, as elites brasileiras inescrupulosas, que, entre 1964 e 1985 , governaram o país. As consequências da ditadura até hoje são perceptíveis - aparato policial corrupto, violações diárias dos direitos humanos e um comportamento brutal contra minorias).

Texto 4) Plastik statt Juta (Plástico em vez de juta)

Nessa resenha, de Florian Borchmeyer, publicada no FAZ, em 18 de outubro de 2008, Milton Hatoum é comparado ao Thomas Mann dos Buddenbrooks ${ }^{12}$ e, assim, exemplos da literatura brasileira são comparáveis

12 Es könnte auch, im Stile einer Art von brasilianischen "Buddenbrooks", als Untertitel "Chronik eines Verfalls" darüber stehen. 
aos clássicos europeus. Hatoum recebe ainda outros elogios, o seu romance é descrito como dotado de uma dimensão impressionante e que fez "escolhas geniais", como a do narrador-testemunha Olavo. Destaca-se a beleza discreta do romance, retrato da decadência de uma era. Quanto aos imagotipos, podemos observar: o Brasil é um paraíso; O Brasil é um país de opressores/ opressores decadentes; O Brasil é um país de diferenças sociais gritantes.

Zu sehen ist auf dem ersten Bild ein tropisches Feudalidyll: ein prunkvolles Herrenhaus in Amazonien mit einem Heer von indianischen Arbeitern am Fluss, unter ihnen der Künstler selbst, der das Geschehen zeichnet. Darüber thront der Herrscher und Besitzer dieses Reiches, den Lieblingshund an seiner Seite. (= No primeiro quadro vê-se um idílio feudal tropical: uma casa senhorial magnífica na Amazônia com um exército de trabalhadores indígenas às margens do rio, entre os quais está o próprio artista desenhando a cena. Entronizado no alto está o senhor e dono desse reino, seu cão de estimação a seu lado) ${ }^{13}$.

Nos trechos que seguem, vê-se o reflexo dos imagotipos: O Brasil tem uma história multifacetada, é um país da multiplicidade, é um país de contrastes; o Brasil é o oposto do Éden.

farben- und facettenreiche Geschichte von Aufstieg und Fall zu zeichnen. (história, rica em cores e facetas, de ascensão e queda).

Figuren eines Allegorienspiels, das Geschichte und Gesellschaft dieser Stadt am Rio Negro mit all ihren schwindelerregenden Höhenflügen und Zusammenbrüchen sinnbildhaft wiedergibt - vom größenwahnsinnigen Bau eines Opernhauses mitten im Urwald über den kollektiven Ruin nach Ende des Kautschukbooms bis hin zum neuen Aufschwung

${ }_{13}$ Os trechos entre aspas são citações do romance. Compare-se com o original de Hatoum em português e observe-se que, curiosamente, o tradutor deixou de fora os caboclos e os japoneses: "Na primeira pintura uma figura masculina aparece de corpo inteiro, olhos cinzentos no rosto severo, ainda jovem, terno escuro e gravata da cor dos olhos, as mãos segurando um filhote de cachorro, e, ao fundo, o casarão de Vila Amazônica, com índios, caboclos e japoneses trabalhadores trabalhando na beira do rio. Mundo, no meio dos trabalhadores, olha para eles e desenha. Nas quatro telas seguintes as figuras e a paisagem vão se modificando, o homem e o animal se deformando, envelhecendo, adquirindo traços estranhos e formas grotescas, até a pintura desaparecer. As duas últimas telas, de fundo escuro, eram antes objetos: numa, pregados no suporte de madeira, os farrapos da roupa usada pelo homem no primeiro quadro, que havia sido rasgada, cortada e picotada; na última, o par de sapatos pretos cravados com pregos que ocupavam toda tela, os sapatos lado a lado mas voltados para direções opostas, e uma frase escrita à mão num papel branco fixado no canto interior esquerdo: História de uma decomposição - Memórias de um filho querido". 
der Stadt als Freihandels-Millionenmetropole (personagens de um jogo de alegorias, que reproduz simbolicamente história e sociedade dessa cidade às margens do Rio Negro, com todos os seus vertiginosos picos e depressões - desde a construção megalomaníaca de um teatro de ópera no meio da floresta, passando pelas ruínas coletivas depois do fim da extração de borracha e adiante até o novo desenvolvimento da cidade como metrópole de livre comércio).

hochprofitablen Export von Tropenhölzern investiert hat. Die einstmals idyllischen Landschaften am Fluss versinken in Müll und Umweltzerstörung. (investiu os altos proventos de suas obras na exportação superlucrativa de madeiras tropicais. A paisagem um dia idílica, às margens do rio, afunda em lixo e destruição ambiental).

\section{Considerações finais}

Podemos supor que a persistência dos imagotipos, em sua antiga face ou transmutados, sirva de ponte, de acesso persuasivo aos temas que realmente interessam aos jornalistas/resenhadores. Vamos assumir a hipótese de trabalho que os imagotipos em relação ao Brasil e nossa literatura, assim como outros estereótipos, provavelmente constituem âncoras textuais necessárias para servir de apoio para a construção de novos sentidos. Mesmo ao retomá-los, os resenhadores podem usá-los para superar esses mesmos imagotipos. Vamos considerar, assim, que esses imagotipos são mais do que meras ferramentas textuais e podem revelar-se elementos de base persuasiva, ancorados em processos de referenciação.

A análise dos processos de construção textual possibilita ao estudante de jornalismo o desenvolvimento de competências exigidas para essa atividade cognitivo-interativa altamente complexa que é a escrita. Além disso, chama a atenção para sua responsabilidade como profissional, na medida em que participa da construção da imagem ou representação de uma cultura. 


\section{Referências}

BARBOSA, F. L. C. Visões seiscentistas do paraíso e do inferno: passos na construção da recepção da literatura brasileira na Alemanha. In: Raído, Dourados, MS, v. 4, n. 7, p. 267-276, jan./jun. 2010. Disponível em: <http://www.periodicos.ufgd.edu. br/index.php/Raido/article/view/599/537>. Consulta feita em 12 nov. 2011.

CAMARGO, K. A. F.. “A imagologia e seus teóricos”. In: Labirinto - Revista eletrônica do centro de estudos do imaginário. Ano VI, nº 9 , janeiro - junho de 2006, Universidade Federal de Rondônia. Disponível emhttp://www.cei.unir.br/ artigog2.html, acesso: 14/11/11.

CASTINO, S. B. A. S. A imagem da literatura brasileira na imprensa alemã: do segundo império até a geração de 45 . Relatório de Pesquisa realizada junto ao CIP da Faculdade Cásper Líbero, 2011.

CAVALCANTE, M. M.; RODRIGUES, B. B.; CIULIA, A. (orgs). Referenciação. São Paulo: Contexto, 2003.

CAVALCANTE, S. M. S. A metáfora no processo de referenciação. Dissertação apresentada à PUC de Minas Gerais, Belo Horizonte, 2002.

CARVALHO, J. M. de. O motivo edênico no imaginário social brasileiro. In: Rev. bras. Ci. Soc., São Paulo, vol. 13 n. $3^{8}$ out. 1998. Disponível em: <http://www.scielo.br/scielo.php>.

DEWULFE, J. "Sobre a mulatização da literatura: o caso do escritor Hugo Loetscher”. In: Línguas e Literaturas. Revista da Faculdade de Letras, n ${ }^{\circ}$ 18, p.511522. Porto, 2001. Disponível em: http://ler.letras.up.pt/uploads/ficheiros/3037.pdf

FRANCIS, G.Rotulação do discurso: um aspecto da coesão lexical de grupos nominais. In: CAVALCANTE, M. M.; RODRIGUES, B. B.; CIULLA, A. (orgs). Referenciação. São Paulo: Contexto, 2003.

KOCH, I.G.V.; MARCUSCHI, L.A. Processos de referenciação na produção discursiva. In: Revista DELTA, 14, p.169-190, 1998.

KOCH, I.G.V. A referenciação como construção sociocognitiva: o caso dos rótulos. In: Rev. Est. Ling., Belo Horizonte, v. 16, n. 1, p. 201-213, jan./jun. 2008.

LEERSSEN, J.Imagology. Amsterdan/New York: Rodopi, 2000. 
MARCUSCHI, L. A. Referenciação e progressão tópica: aspectos cognitivos e textuais. In Revista do GELNE, v. 2, n. 2, 2000.

MELO, C. T. A construção da sinonímia por encapsulamento anafórico: uma perspectiva sóciocognitiva. Tese de doutorado defendida junto à UFP, Centro de artes e comunicação, 2008. Disponível em: <http://www.pgletras.com.br/2008/teses/tese-cinthya-torres.pdf $>$. Acessado em: oq dez. 2010.

MONDADA, L.; DUBOIS, D. Construção dos objetos de discurso e categorização: uma abordagem dos processos de referenciação. In: CAVALCANTE, M. M.; RODRIGUES, B. B.; CIULLA, A. (orgs). Referenciação. São Paulo: Contexto, 2003 .

ROCHA, J. C. C. A guerra de relatos no Brasil contemporâneo. In: Letras. Revista do Programa de Pós-graduação em Letras da UFSM, 2006.

ROMERO, M. S. La investigación textual imagológica contemporânea y su aplicación em el análisis de obras literárias. In: Revista de Filología Alemana, n 28 , 9-28, 2005 .

SOUSA, C. H. M. R. Do cá e do lá. Introdução à Imagologia. São Paulo: Humanitas, 2004 .

"Literatura e imagologia”. In: Pandaemonium germanicum. São Paulo, n. 17, julho/2011, p. 159-186. Consulta em 22/8/11. Disponível em: http://www.fflch. usp.br/dlm/alemao/pandaemoniumgermanicum/site/images/pdf/ed2011.1/o8_Ribeiro_de_Sousa_Celeste.pdf 


\section{Experiência de um laboratório de aprendizagem intercursos de PP e RP}

\section{Introdução}

Com o olhar nas Diretrizes Curriculares dos cursos de Relações Públicas 3 e de Publicidade e Propaganda ${ }^{4}$, no trecho da missão da Pontifícia Universidade Católica do Paraná, que prega promover a formação integral e permanente dos cidadãos, e nas habilidades, perfil do egresso, articulação teoria-prática e atividades extracurriculares propostas pelos Projetos Pedagógicos dos dois cursos, a Célula Coletivo Experimental foi fomentada pelos colegiados para ser um laboratório de aprendizagem que integre os discentes dos dois cursos, como suporte para o refinamento do conhecimento, de agregação de conteúdo, simulando o ambiente de mercado, onde as profissões de diferentes áreas se encontram e precisam somar para a produção de produtos únicos. Como ferramenta de apoio nesta integração, o laboratório está colocando em prática as sugestões do Problem Based Learning (PBL) como estratégia de uniformização da aprendizagem em objetos centrais - chamados de problemas - e oferecendo suporte para as soluções.

1 Trabalho originalmente apresentado no GP Comunicação e Educação, no XV Encontro dos Grupos de Pesquisas em Comunicação, evento componente do XXXVIII Congresso Brasileiro de Ciência da Comunicação. Texto atualizado para esta publicação.

2 Professora nos cursos de Publicidade e Propaganda e Jornalismo e coordenadora da Célula Coletivo Experimental, Laboratório de Aprendizagem da PUCPR. E-mail: ale.ferreiraı@ yahoo.com.br.

3 Resolução CNE/CES n ${ }^{\circ}$ 2, de 27 de setembro de 2013.

4 Resolução CNE/CES n ${ }^{\circ} 492 / 2001$ 
Atrelado ainda ao modelo atual de ensino, de disciplinas segmentadas e agregadas apenas em projetos específicos e no temor de uma atrofia mental, o laboratório nos convida a se afastar do alerta dado por Morin (2000, p. 42-43):

Como nossa educação nos ensinou a separar, compartimentar, isolar e não a unir os conhecimentos, o conjunto deles constitui um quebra-cabeças inintelegível. As interações, as retroações, os contextos e as complexidades que se encontram na man's land entre as disciplinas se tornam invisíveis. Os grandes problemas humanos desaparecem em benefícios dos problemas técnicos particulares. A incapacidade de organizar o saber disperso e compartimentado conduz à atrofia da disposição mental natural de contextualizar e de globalizar.

Ainda dentro desta linha de visualizar o acadêmico como um ser único e já detentor de conhecimento, a formação do acadêmico de Publicidade e Propaganda (PP) e Relações Públicas (RP) no laboratório é estimulada à luz da proposta de Freire (1980): "humanizada" e libertadora.

Se os homens são estes seres da busca e se sua vocação ontológica é a humanização, cedo ou tarde poderão perceber a contradição na qual a educação escolar procura mantê-los e se comprometerão então na luta por sua libertação. Mas o educador humanista revolucionário não pode esperar que esta possibilidade se apresente. Desde o começo, seus esforços devem corresponder com os dos alunos para comprometer-se num pensamento crítico e numa procura da mútua humanização. Seus esforços devem caminhar junto com uma profunda confiança nos homens e em seu poder criador. Para obter este resultado deve colocar-se ao nível dos alunos em suas relações com eles (FREIRE, 1980, p. 80).

Por isso não existe separação a partir de níveis de habilidade e competência, apenas de áreas dentro de uma agência. Além disso, o laboratório também encontrou nas reflexões de Bordenave e Pereira (1982) a respeito do ensino superior o norte que fundamentou a implantação do laboratório aqui apresentado. Admite-se que não se trata de uma inovação na proposta pedagógica, vislumbrada e praticada em muitas outras áreas que já adotam modelos intercursos de integração em atividades práticas há décadas, assim como o PBL, como se reconhece nos cursos da área de saúde. Trata-se apenas de uma aposta em um ambiente multidisciplinar e intercursos em que o discente é detentor das ferramentas na construção do seu próprio conhecimento, conforme ensina a Declaração Mundial sobre Educação Superior no Século XXI: Visão e Ação 1998: "os sistemas de educação superior devem colocar estudantes no 
centro das suas preocupações, dentro de uma perspectiva continuada, para assim permitir a integração total de estudantes na sociedade de conhecimento global do novo século" (UNESCO, 1998, s/p), e encontra suporte permanente de tutores para colocar em prática e ao tempo correto as ações executadas.

Internamente, considera-se que os acadêmicos que integram o laboratório estudam em período integral, mesmo com os dois cursos sendo ofertados apenas nos períodos matutino ou noturno. Pois há um período de aulas tradicionais das disciplinas e, no contraturno, sempre no período da tarde para os dois turnos, os discentes continuam seu aprendizado de forma voluntária, em trabalhos exclusivamente práticos e orientados por professores específicos e dentro do modelo PBL. Os acadêmicos dos dois cursos resolvem questões conjuntamente em produções únicas, respeitando e valorizando as habilidades e competências já desenvolvidas em cada um deles, PP e RP, exatamente como o mercado já clama. Rodrigo Turra (2000, p. 120-122) sugestiona um novo perfil do profissional de comunicação da contemporaneidade:

Ter uma linguagem global, mas atitude local/tribal. [...] E isto faz com que se mude radicalmente o conceito de quem é o comunicador, pois se ele é o guardião da marca, ele é o guardião da empresa inteira. Sua função se confunde com a do marketing no momento em que tem o dever de cultivar e desenvolver a boa imagem da empresa, por meio de bons produtos e serviços prestados, bem como de informações de qualidade. [...] Desta forma, a comunicação da empresa não fica mais presa ao marketing agência. A comunicação deve passar por um planejador de comunicação, um profissional completo, que entenda de mercados e domine todos os instrumentos de comunicação e saiba gerenciá-los de forma ordenada e em conjunto [...]. O comunicador deve ser um administrador de Experiências. Ou seja, este comunicador deve, antes de tudo, pensar em como tornar os contatos dos diversos públicos com marca algo encantador, inesquecível.

E são competências e habilidades que extrapolam a habilitação específica de RP ou PP, mas as une, ao colocar a experiência dos dois, não em confronto, mas em sinergia, propulsionando o desenvolvimento desta habilidade mais ampla, da visão de Comunicação e suas necessidades para as organizações.

\section{Parâmetros norteadores}

A Célula Coletivo Experimental foi implementada ao longo de 2014. No primeiro semestre, etapa de instalação, professores e alunos dos 
dois cursos dividiam um espaço físico comum e desenvolveram produtos específicos. Como um dos pilotos desta etapa, o departamento do laboratório de Pesquisa e Atendimento, formado por dois alunos de cada habilitação do curso de Comunicação Social, RP e PP, desenvolveu, conjuntamente e orientados por um professor de Relações Públicas, uma pesquisa em torno da percepção dos acadêmicos dos dois cursos em relação ao plágio. Tal desenvolvimento embasou toda a construção de um briefing específico para a criação da campanha contra o plágio e da motivação à honestidade intelectual para a Escola de Comunicação e Artes da Pontifícia Universidade Católica do Paraná, desta vez desenvolvido e orientado por professores de Publicidade e Propaganda. Nesta ocasião, não se implantou o PBL, mas foi um experimento do trabalho intercursos.

Além das sustentações já citadas, a concepção do laboratório também foi apoiada pelas premissas de desenvolvimento de Piaget (1982), que prega que o desenvolvimento intelectual é resultado de um intercâmbio dinâmico e ativo do receptor e seu ambiente. Assim, o ambiente físico do laboratório já coloca em sinergia as duas habilitações. E, obviamente, a sua concepção também foi influenciada pela proposta de mediação de Martín -Barbero (2002), que ensina que o objetivo básico do processo de comunicação e do meio não está nas mensagens, mas nos modos de interação que o próprio meio transmite ao receptor, considerando aqui a comunicação como sendo o desenvolvimento das atividades práticas e o receptor os próprios discentes. Assim, os colegiados sugeriram agregar tal premissa ao processo de transmissão do conhecimento, favorecendo um ambiente de interação e apropriação do meio, do conteúdo e do próprio conhecimento, utilizando para isso a ferramenta de PBL. Desta forma, no segundo semestre de 2014, o laboratório foi reestruturado e um coordenador foi acolhido para criar procedimentos e processos que garantissem a integração entre os cursos e o desenvolvimento de projetos comuns. Tal cenário se fez não apenas pelas considerações elencadas acima, mas também pelas orientações das Diretrizes Nacionais Curriculares dos dois cursos envolvidos. Especificamente no curso de Relações Públicas, as então recentes diretrizes serviram de eixo para a reestruturação do laboratório, principalmente naquilo que indica em seu Artigo $5^{\circ}$ :

O curso de Relações Públicas deverá possibilitar formação profissional que revele, pelo menos, as seguintes competências e habilidades: 
I - Gerais:

a) domínio das linguagens e das técnicas utilizadas no processo de comunicação e nas diversas mídias, articulando as dimensões de criação, produção e interpretação;

b) capacidade de articular, de forma interdisciplinar, as interfaces existentes nas diferentes áreas da comunicação, bem como de outros campos do saber, promovendo a integração teórico-prática;

c) atuação profissional em consonância com os princípios éticos de comunicação para a cidadania, considerando as questões contemporâneas, voltadas para os direitos humanos e a sustentabilidade;

d) capacidade de produzir conhecimento científico no campo da comunicação e na área das relações públicas e de exercer a docência (BRASIL, 2013, s/p.

Além de promover tais competências e habilidades dentro das disciplinas e com toda a estrutura da instituição, o refinamento deste conhecimento é possível de ser ampliado através do laboratório de aprendizagem, como a Célula Coletivo Experimental, como indica especificamente o item "b". Além disso, no laboratório, são ofertadas oficinas complementares para que os acadêmicos tenham domínio das ferramentas necessárias para a resolução das atividades propostas, que acabam por integrar as atividades complementares, exatamente como previsto no Artigo $8^{\circ}$ inciso 1 (BRASIL, 2013, s/p),
a) projetos de iniciação científica e de extensão;
b) publicações;
c) participação em cursos, oficinas, eventos, seminários e congressos científicos e profissionais.

Assim, o Projeto Pedagógico de Curso de Relações Públicas da PUCPR em vigor no ano de 2014 considera a Célula um dos seus componentes dos seus Projetos Interdisciplinares:

caracteriza-se como espaço para atividades de extensão que complementam o aprendizado técnico e teórico do aluno com atividades práticas que envolvem o atendimento de clientes reais de mercado do atendimento ao resultado final de comunicação. As atividades de extensão são oferecidas no contra-turno aos alunos de Comunicação Social, visando a formação de excelência de nossos discentes. A justificativa mercadológica consiste em poder atender ao mercado com serviços de comunicação, possibilitando assim o contato do aluno com a realidade de sua profissão. 
Mediante acompanhamento de professores, os estudantes poderão montar portfólio e viver experiências curriculares relevantes para seu crescimento pessoal e profissional (PUCPR, 2013a, p. 17).

Partindo da premissa de construir um ambiente de desenvolvimento das competências ideais do profissional, também o curso de Publicidade e Propaganda trouxe as reflexões das suas Diretrizes Curriculares na concepção do presente laboratório de aprendizagem, principalmente nas características do perfil comum do egresso formado em Comunicação Social:

1. sua capacidade de criação, produção, distribuição, recepção, e análise crítica referentes às mídias, às práticas profissionais e sociais relacionadas com estas, e a suas inserções culturais, políticas e econômicas;

2. sua habilidade em refletir a variedade e mutabilidade de demandas sociais e profissionais na área, adequando-se à complexidade e velocidade do mundo contemporâneo;

3. sua visão integradora e horizontalizada - genérica e ao mesmo tempo especializada de seu campo de trabalho possibilitando o entendimento da dinâmica das diversas modalidades comunicacionais e das suas relações com os processos sociais que as originam e que destas decorrem.

4. utilizar criticamente o instrumental teórico-prático oferecido em seu curso, sendo portanto competente para posicionar-se de um ponto de vista ético-político sobre o exercício do poder na comunicação, sobre os constrangimentos a que a comunicação pode ser submetida (BRASIL, 2001, s/p).

Assim, seu Projeto Pedagógico de Curso (PPC) também acolhe o laboratório dentro do parâmetro de um desenvolvimento crítico e interdisciplinar do publicitário, atendendo a uma visão da própria PUCPR:

compreende-se o trabalho interdisciplinar como uma prática pedagógica que não se ensina nem se aprende, mas é vivenciada, construída, caracterizando-se pela busca, pela pesquisa e pela ousadia em romper os limites das fronteiras estabelecidas entre as várias áreas de conhecimento. Entretanto, cabe respeitar a especificidade do estatuto epistemológico de cada área do saber, estabelecendo-se um diálogo entre elas. $\mathrm{O}$ desenvolvimento de atividades e projetos de cunho interdisciplinar favorece a formação de profissionais pluralistas e ao mesmo tempo com domínio adequado do saber técnico de sua área de atuação. Essa é uma alternativa para a superação da fragmentação dos saberes, contribuindo para a construção de um perfil de egresso que tenha domínio sobre seu campo de conhecimento e seja capaz de dialogar com outros saberes, em um processo permanente de autoformação. Portanto, é fundamental que a execução dos currículos supere 
o fechamento da matriz curricular, desenvolva ações interdisciplinares consistentes que integrem as atividades das Escolas nas dimensões de Pesquisa, Ensino e Extensão. [...] Esse princípio é vivenciado a partir do desenvolvimento da noção de trabalho em grupo em todas as disciplinas da graduação, com outros profissionais, destacando-se o projeto integrador, projeto comunitário e o projeto experimental. A consciência da interdisciplinaridade também é dada na prática profissional proporcionada pelos Estágios (PUCPR, 2013b, p. 22).

À luz do PPC de Publicidade, as ações desenvolvidas pela Célula são viabilizadas como uma das possibilidades das Atividades Complementares, que preveem que:

haja contribuição significativa à ampliação de repertório e do conjunto de critérios para o juízo crítico, o reconhecimento de diferentes correntes de aprendizado e, também, para o reconhecimento de áreas intersubjetivas para a propagação de conteúdos concernentes ao contexto cultural local, regional, nacional e internacional, relevantes à ação educacional que prioriza a interdisciplinaridade como principal articuladora de saberes na construção de conhecimentos (PUCPR, 2013b, p. 37).

A partir de estruturação destes quatro documentos (Diretrizes Curriculares e PPC dos dois cursos acolhidos pelo laboratório), a Célula Coletivo Experimental estrutura-se através de um Regimento Interno aprovado pelos colegiados dos dois cursos. Caracterizado, no seu Capítulo I e Artigo 1 como:

Art. $\mathbf{1}^{\circ}$ - A Agência Intercursos Célula Coletivo Experimental é caracterizada como um laboratório de aprendizagem dos cursos de Relações Públicas e Publicidade e Propaganda, da Escola de Comunicação e Artes da Pontifícia Universidade Católica do Paraná, que visa proporcionar suporte ao aprimoramento prático dos discentes a ela integrada, com atividades monitoradas e sistematizadas extracurriculares. (PPC de PP e RP da PUCPR - 2013, s/P)

\section{E objetiva, segundo seu artigo $6^{\circ}$, de forma não hierárquica:}

I. Fomentar um espaço de prática profissional dentro do ambiente acadêmico, onde discentes dos cursos de Relações Públicas e Publicidade e Propaganda desenvolvam projetos em conjunto;

II. Oportunizar aos discentes a construção de soluções integradas em Comunicação Social;

III. Possibilitar a aplicação dos conhecimentos teóricos em atividades práticas, sempre levando em consideração o paradigma da comunicação integrada; 
IV. Refinar o conhecimento prático dos discentes, dentro do ambiente acadêmico;

V. Aprimorar a construção do perfil profissional com consciência, criticidade e ética;

VI. Desenvolver projetos com qualidade superior para os públicos internos e externos. (PPC de PP e RP da PUCPR - 2013, s/P)

\section{PBL em laboratório}

A Célula implanta, em um modelo extracurricular, o Problem Based Learning (PBL), estratégia pedagógica centrada no aluno e não no docente. Desenvolvido na década de 1960 pela McMaster University, em Hamilton, Ontário, Canadá, e na Holanda (em Maastricht), para a escola de Medicina, é aplicado e criticado há mais de 30 anos, especialmente nas áreas de saúde e engenharia. Há alguns anos começou sua extensão por outras áreas do conhecimento, ainda de forma muito incipiente. Sua base sustenta que, a partir de situações problemas indicadas, almeja-se sua solução através da: observação da realidade, construção de pontos-chave e aplicação na realidade. Assim, os problemas preestabelecidos são ofertados aos discentes e, com todos os suportes adequados, os próprios acadêmicos conseguem efetivamente construir sua base de conhecimentos, trilhando caminhos próprios, excluindo, desta forma, o modelo tradicional de escuta e aferição do conhecimento ao final do período por avaliações escritas e/ou práticas.

De forma superficial, nas práticas adotadas através do PBL na formação de graduação, situações problemas são construídas pelo corpo docente, de acordo com o nível de conhecimento de cada grupo formado, então são entregues aos discentes, que possuem prazos predeterminados para sua execução. Durante sua execução, os acadêmicos possuem suporte para a solução das situações e, ao final, apresenta-se a solução e como chegaram até ela.

Dentro do laboratório de aprendizagem da PUCPR, esses problemas restringuem-se a questões da comunicação, assim delimitados de acordo com seu Regimento Interno:

Pesquisa de Mercado; Planejamento e desenvolvimentos de marcas; Planejamento e execução de ações de comunicação institucional, cobertura fotográfica, mercadológica e interna; Planejamento de mídia; Planejamento e execução de ações de gestão de crise; Assessoria de imprensa e media training; Criação: Desenvolvimento de campanhas, incluindo anúncios, materiais impressos como cartazes e folders e peças 
eletrônicas como vinhetas e vídeos; desenvolvimento de campanhas e conteúdo visual para o ambiente web e mídias sociais. Produção: Produção de conteúdo. (PPC de PP e RP da PUCPR - 2013, s/P)

Assim, no início dos semestres, são formadas equipes com quatro integrantes, baseadas em áreas de interesse dos próprios acadêmicos e não necessariamente das suas áreas de matrícula, RP ou PP: criação e redação, atendimento, pesquisa e planejamento e audiovisual. Cada grupo destes é tutoreado por um professor da área. Após esses processos, são apresentados para todos os problemas, que são necessidades comunicacionais reais, de clientes internos ou externos à instituição, com prazos também preestabelecidos, de acordo com sua complexidade e respeitando o calendário acadêmico da instituição. Após a apresentação e seleção das equipes necessárias para sua execução, os acadêmicos, dentro do ambiente da Célula e utilizando toda a infraestrutura da instituição, iniciam as atividades. Nos primeiros momentos, evidencia-se a prática de um brainstorm e pesquisas de referência, com orientação dos professores. Após essa etapa - e se necessário for, pois há acadêmicos de diferentes períodos dentro do laboratório e nem sempre já com domínio de determinada ferramenta específica para a solução de um problema -, são ofertadas oficinas específicas, como edição sonora ou animação em vídeo. Em seguida, os discentes partem para a execução prática da sua resolução. Ao final, precisam apresentar as soluções à equipe de professores, sempre justificadas e só depois de aprovada é que a solução é encaminhada aos clientes, quando também deve ser apresentada e justificada.

Na experiência já vivenciada pela Célula, nem sempre a primeira solução é aquela acolhida pela equipe de professores. Em inúmeros casos a solução é combatida e solicita-se nova proposta, uma, duas, três vezes, com prazos de entrega mais curtos. Tal prática é o ponto central da vivência no laboratório: a busca e o aprimoramento constante, e não o resultado mensurado através de um valor numérico, representado pela nota. Nota-se que essa rotina, diferente nas aulas tradicionais, num primeiro momento, repele alguns discentes, que se sentem incomodados com as constantes negativas e o embate reflexivo sobre as soluções são comuns. Como se trata de uma atividade voluntária e extracurricular, é natural a desistência de acadêmicos dentro do grupo em um índice que pode superar os $35 \%$ no semestre, motivados exatamente por essa necessidade do refazer, reconstruir, refinar. O grupo que permanece, nos momentos de desistência, é amparado pelos tutores e, se for o caso, novos voluntários são chamados para recompor as equipes. 


\section{Considerações finais}

No período de setembro de 2014 a junho de 2015, a prática do PBL se apresentou adequada para o refinamento do conhecimento dos estudantes de Comunicação, RP e PP, exigindo, no entanto, enorme engajamento do corpo docente. A prática, além de romper com o modelo tradicional, ainda encontra resistência por parte dos acadêmicos, que, estimulados até pela facilidade de acesso e o descarte natural dos bens de consumo, não se sentem confortáveis com a prática do refazer atividades acadêmicas e na busca autônoma por soluções. No entanto, mais que um laboratório de aprendizagem, a Célula tem, de fato, se comportado dentro dos cursos com um espaço coletivo de troca e enriquecimento de experiências entre docentes e discentes dos cursos de Relações Públicas e Publicidade e Propaganda da PUCPR. 


\section{Referências Bibliográficas}

BORDENAVE, J.; PEREIRA, A. M. Estratégias de ensino aprendizagem. 4 a ed., Petrópolis: Vozes, 1982.

BRASIL. Ministério da Educação. Conselho Nacional de Educação. Resolução CNE/CES n ${ }^{\circ}$ 2, de 27 de setembro de 2013. Diretrizes Curriculares Nacionais do Curso de Graduação de Relações Públicas.

BRASIL. Ministério da Educação. Conselho Nacional de Educação. Resolução CNE/CES n ${ }^{\circ}$ 16, de 13 de março de 2002. Diretrizes Curriculares Nacionais dos Cursos de Graduação de Comunicação Social.

BRASIL. Mininstério da Educação. Conselho Nacional de educação. RESOLUÇÃO CNE/CES n ${ }^{\circ}$ 492, de 3 de abril de 2001. Diretrizes Curriculares Nacionais dos Cursos de Graduação de Comunicação Social e suas habilitações.

FREIRE, P. Conscientização: teoria e prática da libertação: uma introdução ao pensamento de Paulo Freire. São Paulo, Moraes, 1980.

MORIN, E. Os sete saberes necessário para educação do futuro. $2^{a}$ ed. São Paulo: Cortez; Brasília, DF: UNESCO, 2000.

MARTIN-BARBERO, J. América Latina e os anos recentes: o estudo da recepção em comunicação social. In: SOUSA, M. W. (org.). Sujeito, o lado oculto do receptor. São Paulo: Brasiliense, 2002.

PIAGET, J. Psicologia e Pedagogia. Rio de Janeiro: Forense Universitária, 1982 PONTIFÍCIA UNIVERSIDADE CATÓLICA DOS PARANÁ. Projeto Pedagógico de Curso, Relações Públicas, 2013 a.

PONTIFÍCIA UNIVERSIDADE CATÓLICA DOS PARANÁ. Projeto Pedagógico de Curso, Publicidade e Propaganda, 2013b.

UNESCO. Declaração mundial sobre educação superior no século XXI: visão e ação. Piracicaba: UNIMEP, 1998.

TURRA, R. O perfil do profissional do próximo milênio frente aos desafios da globalização. In: I SEMANA DE RELAÇÕES PÚBLICAS DE SANTA CATARINA, 2000, Itajaí. Anais... Itajaí: Univali, 2000. 


\section{A formação ética dos jornalistas: relato de experiência docente ${ }^{1}$}

\section{Sérgio Rodrigo da Silva Ferreira ${ }^{2}$ Universidade Federal do Espírito Santo, Vitória, ES}

Antes de perguntar como ensinar ética para estudantes de Jornalismo, é necessário primeiro perguntar se é possível ensinar uma ética. A ética como parte inerente ao processo de ser humano pelo simples fato de sermos sujeitos sociais, em que os valores nos são transmitidos pelo próprio processo de aprendizagem e socialização talvez não possa mesmo ser ensinada, mas provocada e alimentada com diversos elementos simbólicos. Toda a disciplina acaba discutindo, em menor ou maior grau, as melhores formas de agir, o que é bom e bonito, como lidar com o outro, como se constituir como sujeito social e, deste modo, aborda princípios que constituem a ética do sujeito enquanto ser social.

Ao assumir a incumbência de dar aula, junto ao Departamento de Comunicação Social da Universidade Federal do Espírito Santo (Ufes), para a disciplina que trata da Legislação acerca da Comunicação Social e os dilemas éticos que a profissão de jornalista impõe, tendo em vista que essa atividade especificamente tem significativos efeitos sociais e políticos, é que me propus a discutir a abordagem do tema em sala de aula pelos cursos de Jornalismo.

É importante notar que o que chamamos de ética é também, e acima de tudo, um processo estético. A ética, como afirma Eugênio Bucci (2000), nada mais é do que uma singular estética da conduta. É quando afirmamos o que é bom e o belo em nossos fazeres, quando procuramos

1 Trabalho originalmente apresentado no GP Comunicação e Educação, Congresso INTERCOM, Rio de Janeiro, 2015. Texto atualizado para esta publicação.

2 Professor substituto do Departamento de Comunicação Social da Ufes, doutorando pelo Programa de Pós-Graduação em Comunicação e Cultura Contemporâneas da UFBA. E-mail: sergiorodrigosf@gmail.com. 
delimitar a imagem dos bons modos de se fazer jornalismo, ao apontarmos aos nossos alunos qual é a conduta politicamente correta e em linha com a boa imagem da profissão é que tratamos de questões éticas. Valores como a objetividade, a imparcialidade, o desejo e a busca por verdade e precisão, e a confidencialidade, são características da profissão do jornalista e são valores éticos que apontam para uma boa prática do sujeito consigo mesmo, com sua atividade, com seus pares e com a sociedade que recebe seu produto.

É em Foucault (2012) que fui buscar uma base teórica que me permitiu adotar uma perspectiva sobre ética a partir do conceito do Cuidado de Si, pensando a formação da subjetividade a partir do cuidar de si próprio entendido como preocupação por constituir a própria subjetividade. Ao pensar os jogos de verdade em que o sujeito está implicado e entender os modos como este pode manipular esses elementos, é que procurei proporcionar a possibilidade de exercícios de si sobre si mesmo através do qual os alunos procuravam se elaborar, transformar-se e atingir num certo modo de ser (FOUCAULT, 2012), na condição de (futuros) profissionais do campo do Jornalismo. Foi por meio dessa base conceitual que procurei, na teoria e na prática, conceber a disciplina em questão, buscando mobilizar o coletivo em sala de aula e proporcionar a criação de experiências de debate que necessitavam de reflexão sobre suas atitudes, que se atentassem aos seus modos de pensar e que se assumissem enquanto atores transformadores da realidade que criticavam.

A discussão da ética no jornalismo contemporâneo apresenta-se como uma urgência, pois sendo a profissão dependente de uma relação de credibilidade e confiança, as ações dos media impactam toda uma categoria profissional e uma prática consolidada. Pesquisas recentes mostram como estão abaladas as relações entre o público e os meios de comunicação no Brasil. O levantamento sobre a confiança na mídia, realizada pela Secretaria de Comunicação da Presidência da República³, que procurou mensurar o nível de confiança nas notícias veiculadas por diferentes meios de comunicação televisão, rádio, jornais, revistas e internet, mostrou que, na média, apenas $41 \%$ dos entrevistados dizem confiar nas notícias presentes nos suportes midiáticos. Os índices de confiança social nos meios de comunicação, em

3 SECRETARIA de Comunicação Social da Presidência da República. Pesquisa Brasileira de Mídia 2015: hábitos de consumo de mídia pela população brasileira. Disponível em: $<$ http://www.secom.gov.br/atuacao/pesquisa/lista-de-pesquisas-quantitativas-e-qualitativasde-contratos-atuais/pesquisa-brasileira-de-midia-pbm-2015.pdf>. Acesso em 24 jun. 2015. 
pesquisas realizadas pelo instituto Ibope, em 2014, mostram que de 2009 a 2014 houve uma queda de $71 \%$ para $54 \%$ na confiabilidade do público ${ }^{4}$.

Há, assim, uma excepcionalidade nas práticas profissionais do jornalismo que desvela uma relação de poder e que aponta para uma série de questões éticas, transversalmente afetadas pelo fato de que o poder citado não repousa num contrato social (stricto sensu, voto ou nomeação) e em sua função social que tem como substrato a responsabilidade primordial de entregar um bom produto ao seu público. A atuação jornalística é um elemento importante na organização da vida cotidiana, já que de alguma forma as notícias definem noções partilhadas do que é importante na atualidade, dandonos pontos de vista sobre a realidade. São essas mesmas notícias que nos dão satisfação pelo consumo, geram conhecimento e também sugerem respostas para os problemas do cotidiano. Elas, ao emergirem no tecido social pela ação dos meios jornalísticos, atuam no social, (des)configuram referentes coletivos e geram processos que inferem em nossa realidade (SOUZA, 2002).

É deste modo que os jornalistas como produtores de notícia como estes sujeitos que, para a maioria das pessoas, têm como profissão a função de elencar o que é importante a ser discutido na atualidade, testemunhar o real e assim veicular o que é verdadeiro agem nas redes de nossa sociedade por relações de poder que afetam nossos discursos. Tal poder toma corpo ao nos darmos conta de que são estes meios que nos garantem um direito fundamental das sociedades democráticas, que é o direito à informação. Este princípio básico do controle social permite que o cidadão exerça algum controle sobre a ação da administração do Estado e é, na maioria das vezes, por meio da atuação de jornalistas que se efetiva tal direito pertencente a todo o cidadão: o de receber dos órgãos públicos informações de seu interesse (particular ou coletivo) (BERTRAND, 1999; BITELLI, 2004).

Este poder dos media é especialmente problemático quando levamos em consideração que é um serviço público de grande relevância, mas que é exercido, em boa parte das vezes, em empresas privadas que visam ao lucro, nas quais, muitas vezes, as necessidades do público são confundidas com os desejos dos consumidores. Isso por conta da tripla natureza da mídia, que ao mesmo tempo em que é um serviço público (como dito anteriormen-

4 IBOPE. Após queda acentuada em 2013, Índice de Confiança Social se estabiliza. Disponível em: < http://www.ibope.com.br/pt-br/noticias/Paginas/Ap\% $3 \%$ B3s-queda-acentuada-em-2013, Indice-de-Confianca-Social-se-estabiliza.aspx >. Acesso em 24 jun. 2015. 
te, que garante nosso direito à informação por meio de um processo de delegação social, no qual se espera como contrapartida um conteúdo público de qualidade), é também uma instituição política (atuando como o chamado quarto poder, moderando os poderes do Estado, algumas vezes o chantageando e obrigando-o a prestar contas) e uma indústria (estando no lugar entre o interesse público e o financeiro).

Aqui chegamos num ponto crucial para o entendimento da importância do estudo da ética na profissão do jornalista. A prática jornalística tem significativo papel pedagógico, tendo efeito sobre nossas visões de mundo e nossa formação como sujeitos. Ela exerce sobre nossas opiniões e crenças forte influência, especialmente em longo prazo e se sua mensagem for homogênea e constante. Deste modo, dentro do direito à liberdade de expressão, o jornalista deve tentar, constante e voluntariamente, manter o alto sentido de suas responsabilidades.

Fez-se assim durante o desenvolvimento da disciplina em questão não só modos de se apontar os efeitos sociais e políticos da prática jornalística na sociedade, mas, ao estudar a legislação vigente e a deontologia da profissão, tentou-se despertar para o fato de que a normatização das práticas tem função e razão, e que elas são dadas historicamente. Foi importante, por exemplo, contextualizar a criação tanto da Constituição Brasileira quanto a do Código de Ética do Jornalista para mostrar que suas características são próprias da época em que foram criados, mas também evidenciar o fato de que são mutáveis e que têm sempre de estar em processo de revisão para verificar se normas e leis dão conta das vivências hodiernas. É assim que o estudo da deontologia como instrumento complementar se faz importante. A deontologia trata dos princípios, fundamentos e sistemas de moral; é um estudo dos deveres especiais de uma situação determinada, como as da prática do jornalismo, por exemplo. A deontologia não depende do direito nem da moral (no sentido estrito), mas assegura sua função primordial.

Claude-Jean Bertrand (1999) afirma que a deontologia só é praticada na democracia uma vez que o processo de autocontrole feito pelos sujeitos que atuam no jornalismo "só pode ser considerado seriamente onde existem liberdade de expressão, uma certa prosperidade da mídia e jornalistas competentes, orgulhosos de exercer sua profissão" (BERTRAND, 1999, p. 23). A deontologia "no que concerne à mídia, é um conjunto de princípios e regras, estabelecidos pela profissão, de preferência em colaboração com os usuários, a fim de responder melhor às necessidades dos diversos grupos da população" (BERTRAND, 1999, p. 22). 
A deontologia foca nos deveres; são as regras que delineiam os limites à liberdade. Em se tratando da deontologia do jornalismo, é especialmente relevante o poder-dever de informar, uma vez que há uma associação entre eles. É exemplar disso o que diz parte do artigo 220 de nossa Constituição: "a manifestação do pensamento, a criação, a expressão e a informação, sob qualquer forma, processo, ou veículo, não sofrerão qualquer restrição, observando o disposto nesta Constituição" (BRASIL, 2015, p. 36). Fica claro aqui que a liberdade de expressão enunciada não significa ausência de restrições ao seu exercício, mas, ao contrário, conta ela com limites erigidos pelo próprio texto constitucional.

Ciente da importância do debate e querendo envolver os alunos numa discussão que, a princípio, soava pouco estimulante é que procurei tomar como princípio as noções de ética a partir das noções foucaultianas de Cuidado de $\mathrm{Si}$, ou seja, o debate como processo de subjetividade na constituição dos alunos também como profissionais, é que fiz emergir algumas noções práticas de Paulo Freire a respeito da autonomia dos sujeitos no processo pedagógico.

Assim como Freire (2011), procurei levar em conta, principalmente, o conhecimento do aluno em diálogo com a disciplina, porém oposto ao caráter autoritário, assinalando as atitudes para estimulação da liberdade de pensamento e de fala, e também valorizando a experiência de vida como primordial para o efetivo aprendizado. Procurei estimular os alunos no sentido de trazerem suas experiências não só como consumidores de mídia, mas também como estagiários de empresas de comunicação, e resgatarem os exercícios de atuação jornalística que tiveram em outras disciplinas e em outros momentos do curso.

Apesar de ainda muito calcada em modos expositivos de ensino, a disciplina foi pensada de modo a produzir o livre debate, procurando implicar o conteúdo com experiências dos discentes, trazendo para dentro das discussões temas políticos contemporâneos numa perspectiva crítica. Foi em Freire que me baseei para buscar modos de ensino em processos que são obtidos socialmente. Desta maneira, não se tratava de ensinar legislação e ética por meio de atos de transmissão de conhecimentos, mas sim de criação de oportunidades para a construção dos saberes, representando um processo de formação no qual os alunos se tornam sujeitos de seu conhecimento.

O processo de aprendizagem e de Cuidado de Si não era só dos estudantes, mas também era meu, como sujeito que pensa a mídia, e principalmente como sujeito que procura ensinar. Foi assim que fui me experimentando como professor pesquisador. Este trabalho parte da necessidade de me assumir enquanto tal, ao pretender elencar questões relativas às práticas pedagógicas em sala de aula, objetivando aprimorá-las. Ao narrar a 
experiência e apresentar os resultados, procuro não só publicizar uma experiência positiva de aprendizado, mas também refletir sobre práticas futuras na mesma disciplina. Este trabalho se apresenta, assim, como um desafio duplo, pois, sendo um iniciante nas atividades de ensino sobre o tema, soma-se a isso o fato de ser a primeira vez que procuro atuar fora do campo da pesquisa acadêmica, aventurando-me nas escritas por meio da pesquisa de professor.

Regina Leite Garcia e Nilda Alves (2002) já apontavam as significativas diferenças existentes entre a pesquisa do professor e a pesquisa acadêmica ou científica. Se por um lado a pesquisa acadêmica tem por característica, por exemplo, uma preocupação com a originalidade, a validade e a aceitação pela comunidade científica, por seu lado, a pesquisa do professor busca o conhecimento da sua realidade para transformá-la, objetivando melhorar as práticas pedagógicas. Já em relação ao rigor, por outro lado, o professor pesquisa sua própria prática, encontra-se envolvido com seu objeto de pesquisa, diferentemente do pesquisador teórico. Quanto aos objetivos, a pesquisa do professor tem caráter utilitário, os resultados existem para serem usados na sala de aula, enquanto a pesquisa acadêmica em geral está conectada com objetivos sociais e políticos mais amplos (GARCIA; ALVES, 2002).

É assim que me assumo e me constituo como professor investigador, ao examinar minha prática, identificar problemas, formular hipóteses, questionar valores, observar o contexto institucional e cultural ao qual pertenço, participar do desenvolvimento curricular, assumir a responsabilidade por meu desenvolvimento profissional e fortalecer as ações em grupo. Tomo como objeto de pesquisa, análise e discussão de minha própria realidade escolar.

A experiência em questão aconteceu no primeiro semestre de 2015 , no CEMUNI 5, prédio do Centro de Artes da Universidade Federal do Espírito Santo. Eram 23 alunos do $5^{\circ}$ período do curso de Jornalismo, em sua grande maioria mulheres (havia dois homens) entre 20 e 25 anos. A ementa fixa da disciplina que me foi proposta era a seguinte: "Estudo da legislação vigente e aplicável em matéria de jornalismo. Códigos deontológicos ligados à atividade profissional de imprensa. Apreciação das mensagens jornalísticas ante seus reflexos positivos ou negativos em relação a pessoas, grupos sociais e público em geral. Comprometimento ético do profissional do jornalismo".

A partir da referida ementa é que formulei o programa da disciplina. Estabeleci como objetivos gerais: “conhecer os mecanismos legais, normativos e éticos que orientam a atividade do jornalismo. Analisar criticamente casos de ética profissional. Desenvolver uma visão crítica em 
relação à atividade”. Como objetivos específicos: "Discutir as implicações sociais e políticas da prática do jornalismo e sua normatização. Levantar questões éticas a partir da análise do fazer jornalístico”.

Dividi o conteúdo programático da disciplina em três unidades, sendo que a primeira era Poder, normatização e legislação; a segunda, Ética e questões trabalhistas; e a terceira, Direitos humanos e a prática jornalística. Essas unidades foram subdivididas em tópicos que procuravam, como dito anteriormente, não só evidenciar a legislação e normatização da prática dos meios de comunicação no Brasil, mas provocar seu debate no sentido de produzir o entendimento de seus sentidos dados social e historicamente (ver Figura 1).

Além da bibliografia básica e complementar, baseada em livros, artigos de revistas e textos on-line, foi adotada uma série de referências audiovisuais apresentadas ao longo da disciplina, sendo matérias de telejornais, documentários, vídeos publicitários, filmes de ficção e vídeos institucionais, e também se referenciou produtos jornalísticos atuais, impressos e on-line, como forma de ilustração de conceitos.

A avaliação da disciplina baseou-se em exercícios de análise fílmica5, numa prova escrita com consulta (em que os discentes tinham que resolver uma questão ética e precisaram avaliar a questão do ponto de vista do direito da comunicação, das questões éticas e das práticas profissionais que estavam postas) e numa atividade de pesquisa de estudos de caso.

A referida atividade de pesquisa mostrou-se especialmente produtiva. Foi proposto aos alunos que selecionassem uma matéria recente em um veículo de comunicação de qualquer gênero (impresso, televisão, rádio ou on-line) ou um fato que, conforme o discutido em sala de aula, no entendimento deles, ferisse o código de ética do jornalismo. Era necessário que eles explicassem o motivo da escolha descrevendo as implicações éticas. Foi pedido que os estudantes contribuíssem com um comentário crítico refletindo de que forma a situação retratada poderia ser revista, mudada e transformada. A coleta dos dados e análise deveriam gerar um texto de uma lauda, que deveria ser apresentado e discutido com os colegas em sala de aula.

Inicialmente pensada como atividade para durar uma aula, os debates se estenderam por três semanas. Cada trabalho apresentado permitiu que

5 Os estudantes analisaram sob o ponto de vista da ética jornalística os acontecimentos no filme "Doces Poderes", de Lucia Murat (MURAT, Lúcia. Doces Poderes. [Filme-vídeo]. Brasil, 1996. 102 min. color. son.) e o documentário "A Constituição Cidadã”, produzido para a TV Senado. 
FIGURA 1 - Visão geral da primeira página do programa da disciplina.

\begin{tabular}{|c|c|c|c|c|c|}
\hline ㄴ.12 & \multicolumn{4}{|c|}{$\begin{array}{l}\text { Universidade Federal do Espírito Santo } \\
\text { Centro de Artes - Departamento de Comunicação Social } \\
\text { Curso de Comunicação Social - Jornalismo }\end{array}$} & $15 / 01$ \\
\hline \multicolumn{6}{|c|}{ PROGRAMA DE DISCIPLINA } \\
\hline $\operatorname{COS} 04835$ & \multicolumn{4}{|c|}{ LEGISLAÇÃO EM COMUNICAÇÃO (Jornalismo) } & Período \\
\hline \multirow{2}{*}{\multicolumn{2}{|c|}{$\begin{array}{c}\text { Carga Horária Total } \\
60 \mathrm{~h}\end{array}$}} & \multirow{3}{*}{$\begin{array}{c}\text { Créditos } \\
04\end{array}$} & \multicolumn{3}{|c|}{ Distribuição da Carga Horária Semanal } \\
\hline & & & Teoria & Exercício & Laboratório \\
\hline \multicolumn{2}{|c|}{ Turma: 01} & & $2 \mathrm{~h}$ & $2 \mathrm{~h}$ & Oh \\
\hline
\end{tabular}

\section{EMENTA}

Estudo da legislação vigente e aplicável em matéria de jornalismo. Códigos deontológicos ligados à atividade profissional de imprensa. Apreciação das mensagens jornalisticas ante seus reflexos positivos ou negativos em relação a pessoas, grupos sociais e público em geral. Comprometimento ético do profissional do jornalismo.

\section{OBJETIVOS}

Geral: Conhecer os mecanismos legais, normativos e éticos que orientam a atividade do jornalismo. Analisar criticamente casos de ética profissional. Desenvolver uma visão crítica em relação à atividade. Específicos: Discutir as implicações sociais e políticas da prática do jornalismo e sua normatização. Levantar questões éticas a partir da análise do fazer jornalístico.

\begin{tabular}{l} 
CONTEÚDO PROGRAMÁTICO \\
\hline Unidade 1 - PODER, NORMATIZAÇÃO E LEGISLAÇÃO \\
1.1 Poder, micropolitica e a opinião pública como aclamação moderna. \\
1.2 Conceitos de regulação. Normatização e modernidade. \\
1.3 Deontologia para comunicação. \\
1.4 Legislação Brasileira e a regulamentação da comunicação. \\
Unidade 2 - ÉTICA E QUESTÕES TRABALHISTAS \\
2.1 Ética e a ética trabalhista. \\
2.2 Código de Ética do Jornalismo: história, características e aplicações. \\
2.3 A profissão do jornalista. \\
Unidade 3 - DIREITOS HUMANOS E A PRÁTICA JORNALíSTICA \\
3.1 Comunicação para os Direitos humanos. \\
3.2 Movimentos Sociais e minorias.
\end{tabular}

$$
\text { BIBLIOGRAFIA BÁSICA }
$$

- BERTRAND, Jean-Claude. A deontologia das midias. Bauru: Edusc, 1999.

- BUCCI, Eugênio. Sobre ética e imprensa. São Paulo: Companhia das Letras, 2000.

\begin{tabular}{|l|}
\hline \multicolumn{2}{|c|}{ BIBLIOGRAFIA COMPLEMENTAR } \\
\hline Bibliográficos: \\
- BITELLI, Marcos Alberto Sant'Anna. Coletânea de Legislação de Comunicação Social. São Paulo: \\
Revista dos Tribunais, 2010. \\
- O direito da comunicação e da comunicação social. São Paulo: Revista dos Tribunais, 2004. \\
\hline
\end{tabular}


fosse discutida a práxis jornalística em todos os seus territórios: da mensagem e dos códigos; dos meios e modos de produção das mensagens; do contexto comunicacional das mensagens; do emissor ou fonte da comunicação e do destino e da recepção da mensagem. Além disso, mostrou-se uma excelente forma de debater e discutir questões políticas contemporâneas. Por meio das matérias também se pôde discutir sobre a situação atual do país, e foram levantadas questões de direitos humanos e minorias, de gênero, de sexo, de raça, de infância, de consumo, de segurança pública, de educação e de trabalho.

Entre os temas levantados pelos discentes nas matérias de jornais estavam a violência em bairros periféricos, a ação violenta da polícia contra manifestações pacíficas, as banalidades da vida de celebridades, os métodos de emagrecimento, o roubo, o estupro, o feminicídio, o suicídio, o assassinato, os privilégios de políticos, o espancamento, a ação de milícias e a atividade privada de família de políticos. Além das matérias, foi levantado como assunto de análise a ação de jornalistas que publicam em redes sociais on-line sem apuração.

Por meio dos casos levantados, os alunos apontaram como problemas éticos no jornalismo contemporâneo a falta de conteúdo de interesse público, a publicação de conteúdo sem relevância social, o desrespeito à intimidade, privacidade, honra e imagem dos cidadãos, a exposição de pessoa ameaçada e/ou sob risco de vida, o tratamento desrespeitoso às pessoas, a falta de veracidade de algumas abordagens tendenciosas, abordagens racistas e machistas, o desrespeito aos Direitos Humanos, o desrespeito à integridade física e moral do indivíduos, veiculação de conteúdo de caráter mórbido, a opressão de minorias e a banalização da violência.

Ocupou especialmente a crítica dos alunos o fato da veiculação de conteúdo de irrelevância pública e/ou com enquadramento não crítico ou pouco abrangente. Sobre este aspecto um dos alunos escreveu:

O jomalista deve prestar informações de relevância a qualquer cidadão de direito. Acredito que uma notícia que tem como objetivo querer saber se um barbante é capaz de fazer uma pessoa perder peso ou não, não atende a isso.

Outra preocupação que esteve bastante presente nas análises dos estudantes foi a banalização da violência no relato dos motivos apresentados. Os alunos mostraram-se bastante sensibilizados com as questões de violência motivada por racismo, homofobia, misoginia e contra a população pobre. Ilustra este viés o estudante que trouxe para o debate o caso de homicidas, chamados pelo jornal de "justiceiros", que mataram um cidadão por não pagar uma passagem de ônibus: 
Quando o valor de uma vida se tornou menos importante que uma passagem? Ainda que o transporte seja pago e todos estejam insatisfeitos com ele, deve-se tomar cuidado ao dar o aval para que a loucura se instale e as pessoas comecem a matar por $R \$ 2,45$.

Em meio às análises que foram feitas houve críticas contundentes aos programas de televisão de viés sensacionalista, tão em voga atualmente. O sensacionalismo se inclui como um gênero jornalístico que propõe atingir o público justamente pelo choque, explorando temas em tom espalhafatoso e com a finalidade de provocar emoção ou escândalo. Para isso, procura tratar de temas como crimes, desastres, sexo, escândalos, hábitos exóticos, etc.

O debate em torno deste tema esteve presente especialmente num caso que tratava de uma cobertura sensacionalista de um sequestro, em que a apresentadora de um programa de TV negociava com o sequestrador por telefone ao vivo em rede nacional:

O acontecimento ganha espectadores, como se o caso fosse uma novela a ser acompanhada capitulo por capítulo [...]. Embora não se trate de uma obra ficcional ou de um programa de reality show para ser acompanhado com tanta fidelidade e expectativa, é tratado como. Ignoram-se os limites do bom senso e da ética, e se esquecem que o caso é mesmo da vida real. Tudo pela audiência!

Apareceu nas análises dos discentes a crítica negativa à linguagem destes programas que valorizam a emoção em detrimento da informação, que exploram o vulgar de forma espetacular, pelo uso de linguagem coloquial, pelo destaque a elementos supérfluos e pela subtração de outros importantes, pela invenção de palavras e fatos e pela descontextualização política, econômica, social e cultural. A análise feita por um estudante ilustra este posicionamento:

A estrutura dessa reportagem e desse programa intervém diretamente na construção social do cidadão que entra em contato com esse conteúdo. $O$ telejornal ocupa espaço em um meio de muita visibilidade e está na posição de formador de opinião, por isso uma reportagem como essa deveria estar isenta de qualquer comentário que violasse os direitos humanos. Abordando o fato de forma menos factual, não é apenas mais um corpo em qualquer assassinato em Cariacica, é um cidadão que foi morto de forma violenta em um dos estados mais violentos do Brasil, como mostra o mapa da violência, e nada tem sido feito para tratar do problema.

Além da crítica ao sensacionalismo, as análises apontaram ainda para outros problemas no jornalismo, como a incitação da violência nos discursos de alguns veículos, a parcialidade, enquadramentos politicamente incorretos e falta de aprofundamento. 
Foi especialmente gratificante o resultado positivo da disciplina em minha primeira experiência no ensino deste tema, ainda mais tendo uma missão tão complicada como é a de tratar da ética no jornalismo. Foi fundamental para o sucesso da experiência estar corporalmente envolvido nas discussões, debater respeitando as alteridades e atuar em prática testemunhal que confirmava o que se dizia.

Como nos diz Paulo Freire, ensinar exige estética e ética: somos seres históricos e sociais, somos capazes de comparar, valorizar, intervir, escolher, decidir, romper e, por isso, deste modo nos fazemos seres éticos.

É por isso que transformar a experiência em puro treinamento técnico é amesquinhar o que há de fundamentalmente humano no exercício educativo: o seu caráter formador. Se se respeita a natureza do ser humano, o ensino dos conteúdos não pode dar-se alheio à formação moral do educando. Educar é substantivamente formar (FREIRE, 2011, p. 16).

\section{Referências}

BERTRAND, C.. A deontologia das mídias. Bauru: Edusc, 1999.

BITELLI, M. A. S.. O direito da comunicação e da comunicação social. São Paulo: Revista dos Tribunais, 2004.

BRASIL. Constituição (1988). Constituição da República Federativa do Brasil: promulgada em 5 de outubro de 1988. Disponível em: <http:/www.senado.gov.br/ legislacao/const/con1988/con1988_05.10.1988/con1988.pdf>. Acesso em 3 jul. 2015..

BUCCI, E.. Sobre ética e imprensa. São Paulo: Companhia das Letras, 2000.

FOUCAUlT, M.. Ética, Sexualidade, Política. Rio de Janeiro: Forense Universitária, 2012. (col. Ditos \& Escritos).

FREIRE, P.. Pedagogia da autonomia: saberes necessários à prática educativa. 43. ed.. São Paulo: Paz e Terra, 2011.

GARCIA, R. L.; ALVES, N.. Conversa sobre pesquisa. In: ESTEBAN, M. T.; ZACCUR, E. (Orgs). Professora-pesquisadora: uma práxis em construção. Rio de Janeiro: DP\&A, 2002.

SOUSA, J. P.. Teorias da notícia e do Jornalismo. Chapecó: Argos, 2002. 


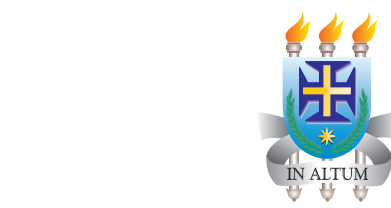

IMPRENSA UNIVERSITÁRIA

Impresso na gráfica da Universidade Estadual de Santa CruZ - Ilhéus-BA 